UNIVERSIDADE DE SÃO PAULO

INSTITUTO DE RELAÇÕES INTERNACIONAIS

OTÁVIO MACEDO VIEGAS

A União Européia na governança global: uma análise de negociações de comércio com os BRICS e o GCC 
OTÁVIO MACEDO VIEGAS

\title{
A União Européia na governança global: uma análise de negociações de comércio com os BRICS e o GCC
}

\author{
Versão Corrigida \\ (Versão original encontra-se na unidade que aloja o Programa de Pós-graduação)
}

Tese apresentada ao Instituto de Relações Internacionais da Universidade de São Paulo para a obtenção do título de Doutor em Ciências.

Orientadora: Profa. Dra. Janina Onuki

São Paulo 
Autorizo a reprodução e divulgação total ou parcial deste trabalho, por qualquer meio convencional ou eletrônico, para fins de estudo e pesquisa, desde que citada a fonte.

Catalogação na Publicação*

Instituto de Relações Internacionais da Universidade de São Paulo

Viegas, Otavio Macedo

A União Européia na Governança Global: uma análise de negociações de comércio com os BRICS e o GCC/ Otavio Macedo Viegas --

Orientadora Janina Onuki. São Paulo: 2019 $245 p$.

Tese (doutorado). Universidade de São Paulo. Instituto de Relações Internacionais.

Versão corrigida

1.União Européia. 2. Política Comercial. 3. Realismo. 4. BRICS. 5. GCC. I. Onuki, Janina, orient. II. Título. 
Nome: Otávio Macedo Viegas

Título: A União Européia na Governança Global: uma análise de negociações de comércio com os BRICS e o GCC

Tese apresentada ao Instituto de Relações Internacionais da Universidade de São Paulo para obtenção do título de Doutor em Ciências.

Aprovado em: 26/04/2019

Banca Examinadora

Profa. Dra. Janina Onuki

Instituição: IRI-USP (orientadora)

Prof. Dr. Amâncio Jorge Nunes de Oliveira

Instituição: IRI-USP

Julgamento: Aprovado

Prof. Dr. Bruno Martarello de Conti

Instituição: UNICAMP

Julgamento: Aprovado

Prof.Dr. Demétrius Césario Pereira

Instituição: ESPM

Julgamento: Aprovado 
O presente trabalho foi realizado com apoio da Coordenação de Aperfeiçoamento de Pessoal de Nível Superior - Brasil (CAPES) - Código de Financiamento 001. 


\section{Agradecimentos}

O autor gostaria de agradecer à CAPES (Demanda Social) pelo apoio financeiro que viabilizou a realização desta pesquisa. Igualmente, também gostaria de agradecer à minha orientadora, Profa. Janina Onuki, pelos comentários e leitura de versões prévias da tese, bem como recomendações de leitura muito importantes para a realização do trabalho.

Seria impossível agradecer a todos que viabilizaram a elaboração desta tese, mas agradecimentos especiais são devidos a: meus pais, pelo apoio incondicional desde o início desta pesquisa até hoje; meu irmão Renato - que está longe, mas sempre presente -; à minha avó "Nena", que me incentivou a iniciar este trabalho, mas nos deixou em 2016.

Agradeço também à Professora Adriana Schor pelo apoio e trabalho à frente da CPG desde 2018.

Por fim, agradeço à Professora Katharina Meissner do Centre for European Integration Research de Viena, pela leitura de partes do trabalho, recomendações de leituras, teses, e sobre aspectos metodológicos do trabalho. 
« Dire aux autres ceci ou cela

C'est le son sourd de la rumeur Mais quand ton propre cœur demande Sais-tu quelle réponse lui donner?» (YOSHINOBU ET AL., 951) 


\section{Índice}

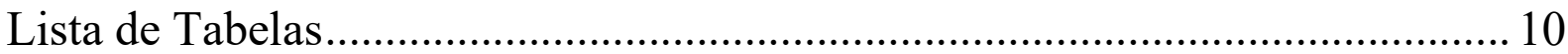

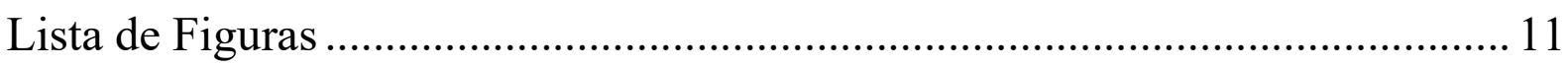

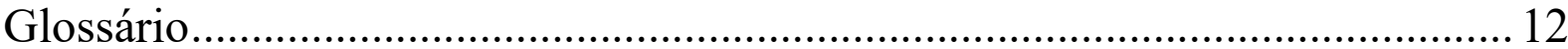

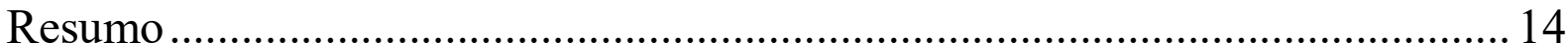

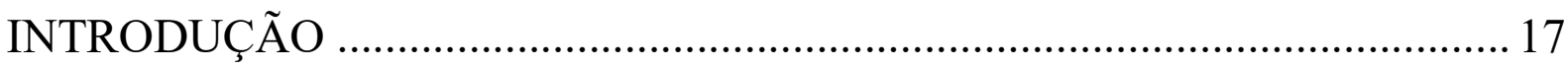

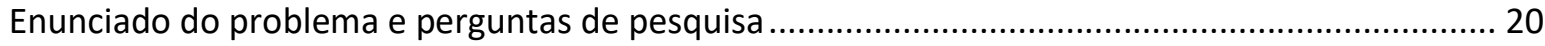

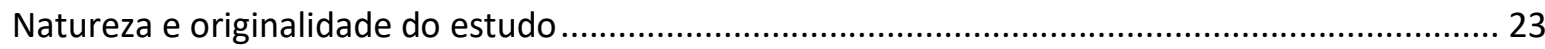

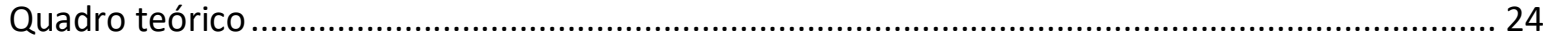

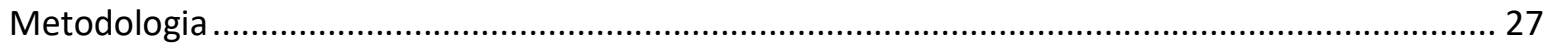

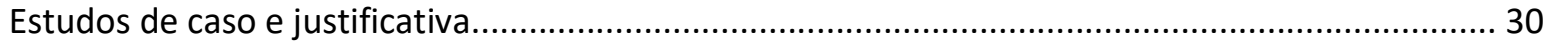

Limites às abordagens teórica e metodológica................................................................................. 32

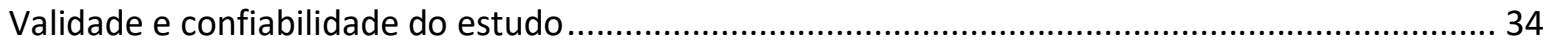

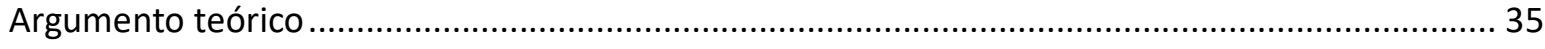

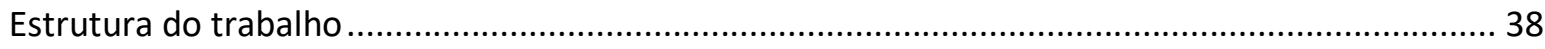

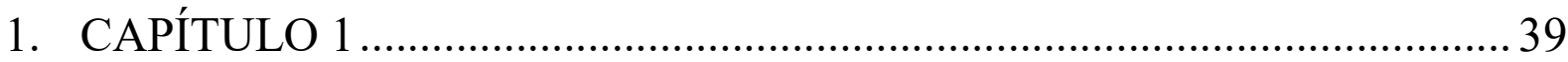

Revisão da literatura: O debate sobre política externa comercial da UE............ 39

1.1. Definição de política externa e política comercial ............................................................. 39

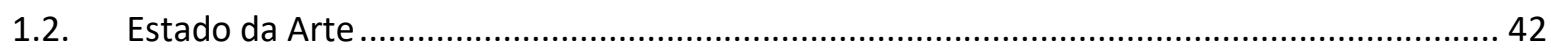

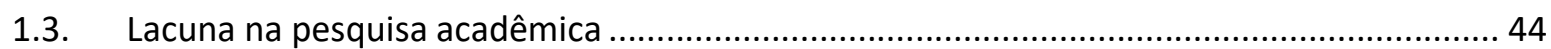

1.4. Estratégias em relação a países emergentes (BRICS, América Latina, África e Sudeste

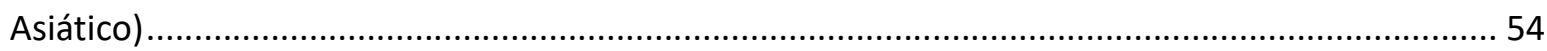

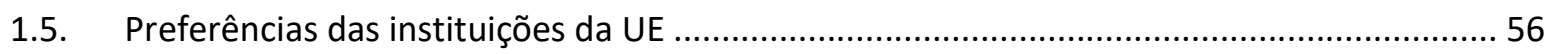

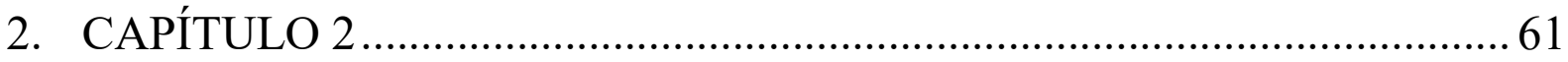

Realismo Comercial e potências emergentes...................................................... 61

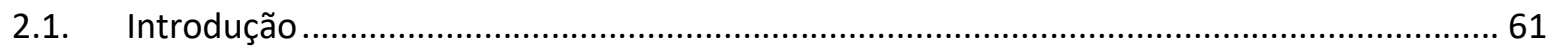

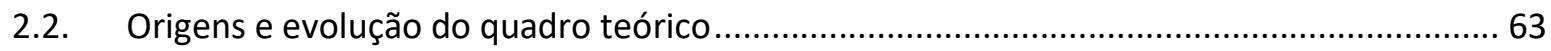

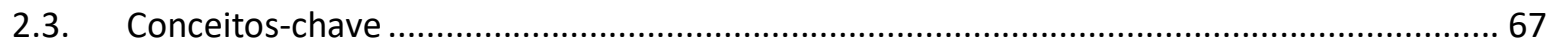

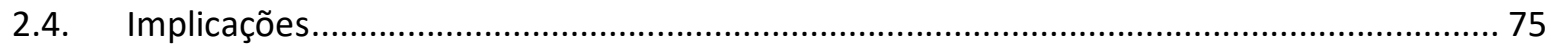

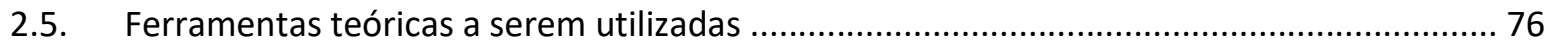

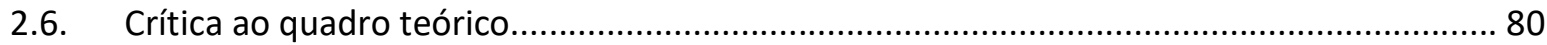

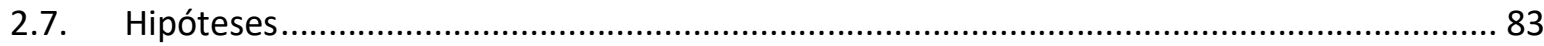




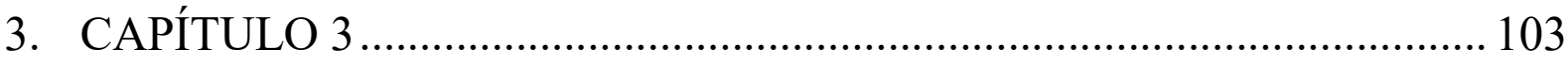

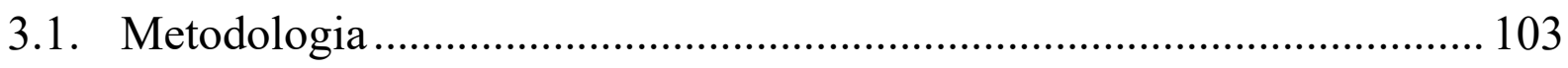

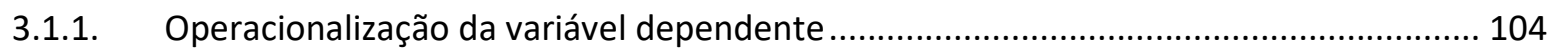

3.1.2. Operacionalização das variáveis independentes ......................................................... 105

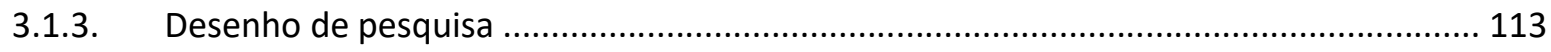

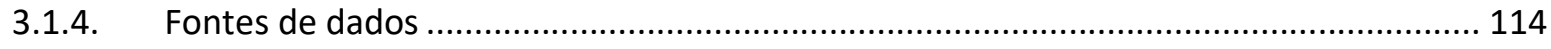

3.2. UE na arena internacional de comércio: estudos de caso ........................ 116

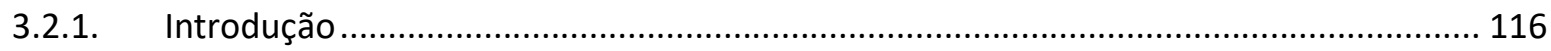

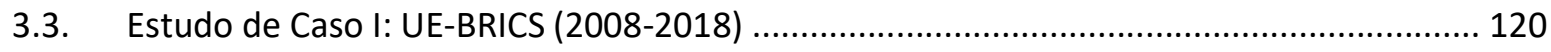

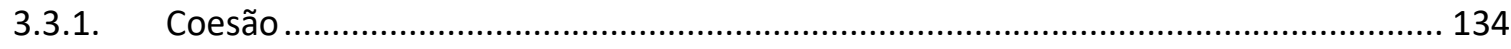

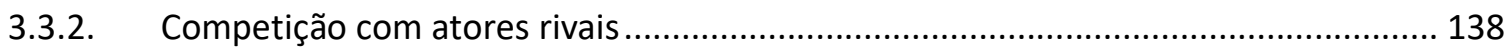

3.3.3. Nexo entre política externa e política comercial ...................................................... 142

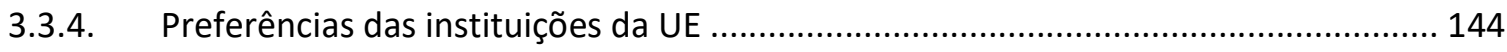

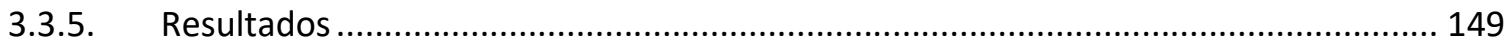

3.4. Estudo de caso II: UE - GCC (Conselho de cooperação dos países do Golfo) ...................... 154

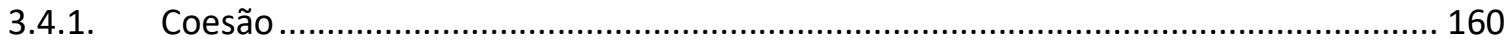

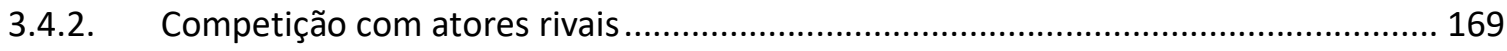

3.4.3. Nexo entre política externa e política comercial ........................................................ 173

3.4.4. Preferências das instituiçø̃es da UE ......................................................................... 175

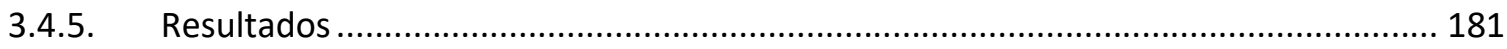

3.5. Estudo de caso III: TTIP (Parceria transatlântica de investimento e comércio) ................... 184

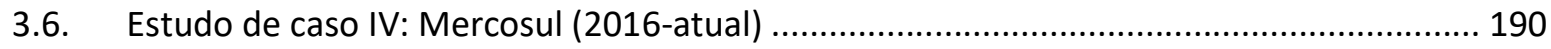

3.7. Estudos de caso V: CETA (Canadá), Coréia do Sul e Japão ................................................. 200

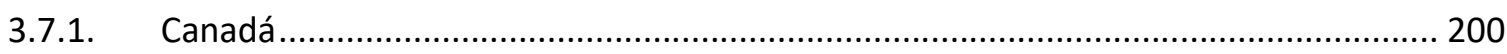

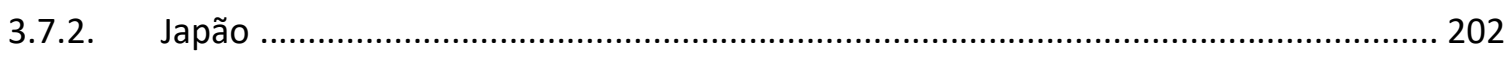

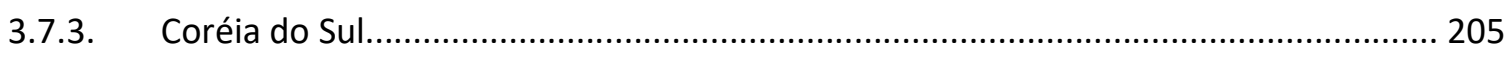

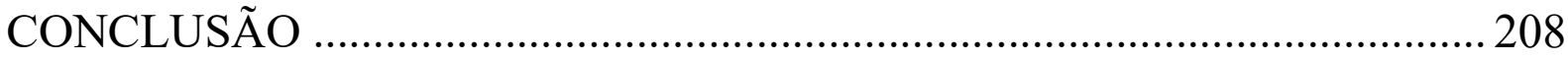

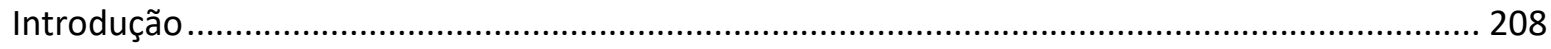

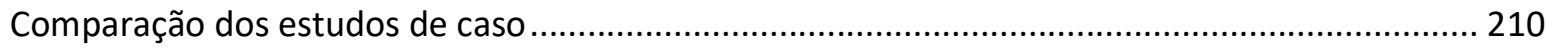

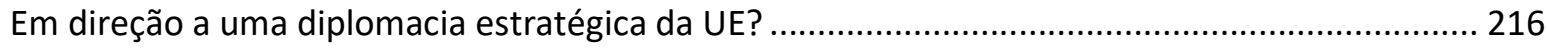

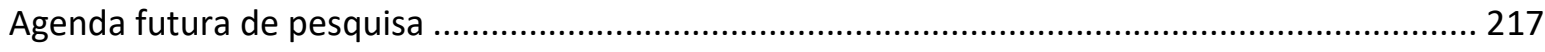

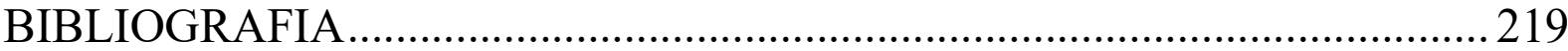




\section{Lista de Tabelas}

Tabela 1: Preferências por interesse materiais vs. valores das instituições da UE

Tabela 2 Índice de coesão desenvolvido por Meissner

Tabela 3: Resultados de acordo com o Realismo Comercial.

Tabela 4: Mecanismo causal da Hipótese 1

Tabela 5: Mecanismo causal da Hipótese 2

Tabela 6: Mecanismo causal da Hipótese 3

Tabela 7: Mecanismo causal da Hipótese 4

Tabela 8 Operacionalização da variável dependente.

Tabela 9: Evidência empírica esperada para a Hipótese 1 106

Tabela 10: Evidência empírica esperada para a Hipótese 2 108

Tabela 11: Evidência empírica esperada para a Hipótese 3

Tabela 12: Evidência empírica esperada para a Hipótese 4

Tabela 13: Coesão dos BRICS (2014-período atual)

Tabela 14: Coesão do GCC (2003-2011)

Tabela 15: Coesão do GCC (2011-2018)

Tabela 16: Resultados para a variável dependente, complementando os casos analisados por

Meissner (2016), McCrossan (2014) e Schade (2016). 211 


\section{Lista de Figuras}

Figura 1: Conceituação da política comercial externa da UE, segundo o esquema proposto por

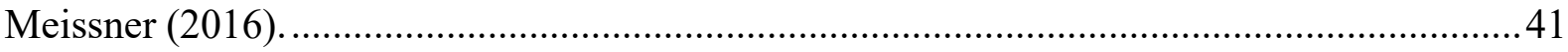

Figura 2: Índice de coesão de Meissner adaptado para coalizões ........................................ 74

Figura 3: Quadro de teste de teorias proposto por Meissner (2016) ......................................79

Figura 4: Exportações agregadas da UE-27 para os estados BRIC (milhões de Euro) .......... 130

Figura 5: Alianças de potências emergentes e outros quadros multilaterais .......................... 138

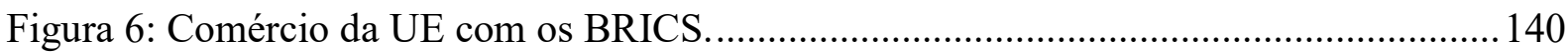

Figura 7: Fluxo e equilíbrio comercial entre a UE e o GCC …............................................. 165

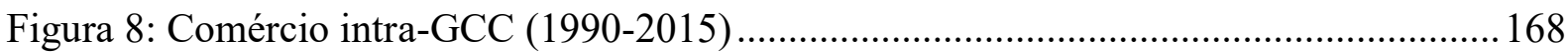

Figura 9: Importações da China provenientes dos países do GCC (2003-2011) ....................172

Figura 10: Importações da China provenientes dos países do GCC (2012-2017).................. 173 


\section{Glossário}

AA: Acordo de Associação

ABC: Acordo Bilateral de Comércio

ACP: África, Caribe e Pacífico

APCs: Acordos Preferenciais de Comércio

APE: Acordo de Parceria Econômica

ASEAN: Associação dos Países do Sudeste Asiático

CAN: Comunidade Andina De Nações

CRA: Contingent Reserve Arrangement

BRICS: Brasil, Índia, China, Rússia e África do Sul

DESTA: Design of Trade Agreements

DG: Diretoria-Geral

EMs: Estados Membros

EUGS: European Union Global Strategy

SEAE: Serviço Europeu de Ação Externa

FMI: Fundo Monetário Internacional

GCC: Gulf Cooperation Council

GIs: Grupos de Interesse

MERCOSUL: Mercado Comum do Sul

MEI: Major Economic Indicators 
NAFTA: Associação de Livre-Comércio da América do Norte

OCDE: Organização para Cooperação e Desenvolvimento Econômico

OMC: Organização Mundial do Comércio

PCC: Política Comercial Comum

PEC: Política Externa Comercial

PESC: Política Externa e de Segurança Comum

PCSD: Política Comum de Segurança e Defesa

SGP: Sistema Geral de Preferências

TiSA: Trade in Services Agreement

TFEU: Tratado Sobre o Funcionamento da União Europeia

TRIPs: Acordo sobre aspectos dos direitos de propriedade intelectual relacionados ao comércio

TTIP: Parceria Transatlântica de Comércio e Investimento

UE: União Europeia 


\section{Resumo}

As análises tradicionais de política comercial da UE derivam dos quadros teóricos do liberalismo comercial, do agente principal ou do liberal-institucionalismo. Pouquíssimos trabalhos têm abordado essa arena de política como parte da política externa da UE, ou utilizado uma abordagem da tradição realista de relações internacionais. Este trabalho traz uma contribuição para a análise do posicionamento da UE em relação aos BRICS e ao GCC (Gulf Cooperation Council), dois blocos que não tem sido alvo de uma estratégia articulada do bloco europeu - e como estudos de caso secundários também são analisados os casos do Mercosul e da Parceria Trans-Atlântica (TTIP). A abordagem teórica utilizada deriva do quadro do realismo comercial desenvolvido por Meissner (2016), que explica como região homóloga, atores rivais, Estados Membros e grupos de interesse levam a um desenho inter-regional ou bilateral de política. Igualmente, também se avalia o uso de instrumentos comerciais para atingir objetivos de política externa e a ênfase recente da UE em instrumentos bilaterais na arena do comércio exterior - dois assuntos que tem sido pouco explorados na literatura de relações internacionais.

Palavras-chave: União Europeia; Comércio; Realismo; Estratégia; Política Externa 


\begin{abstract}
Traditional analyses of EU trade policy stem from the theoretical frameworks of commercial liberalism, principal-agent or liberal-institutionalism. Very few works have approached this policy arena as part of EU's foreign policy, or used an approach from the realist tradition of international relations. This work analyzes the EU's approach to the BRICS and the GCC (Gulf Cooperation Council) blocs, which have not been the subject of a specific European strategy - and also the secondary case-studies of Mercosul and of the Trans-Atlantic Partnership (TTIP). The theoretical framework employed here derives from the commercial realism thesis developed by Meissner (2016) that explains how rival actors, counterpart region, member states and interest groups lead to an interregional or bilateral policy design. However, we also take into account the use of trade instruments to advance foreign policy goals and the EU's recent emphasis in concluding bilateral deals - two subjects which have been neglected by the International Relations literature.
\end{abstract}

Key-words: European Union; Trade; Realism; Strategy; Foreign Policy 


\section{INTRODUÇÃO}

A ascensão dos BRICS tem sido objeto de interesse acadêmico intenso, desde pesquisas que se focam exclusivamente no aspecto financeiro da cooperação e ação internacional desses países, até estudos com foco em questões de segurança que envolvem a atuação conjunta desses atores. Igualmente, esses estados tem sido investigados do ponto de vista de sua atuação na Organização das Nações Unidas, em um contexto de profundas transformações na governança global e na distribuição internacional de poder. Dessa forma, a ascensão econômica desses países não-ocidentais tem implicações muito além de seu agrupamento inicial como um acrônimo criado por um banqueiro de investimentos.

Diferentemente dos BRICS, a União Europeia é uma organização regional com uma história muito mais extensa, cuja origem remonta a 1951 com o Tratado de Paris. Em alguns meses, a eleição mais crucial da história da União poderá selar o destino da experiência de integração regional mais avançada que o mundo conhece hoje - e igualmente comprometer os objetivos dos pais fundadores de assegurar a paz e cooperação no velho continente. Muitos acadêmicos e políticos já notam o caráter de declínio que atualmente caracteriza a União Europeia. O estudo da guerra e da paz, central para a disciplina de relações internacionais, encontra no Realismo uma de suas correntes mais antigas.

No entanto, poucos estudos têm estudado a projeção da política comercial da UE na arena internacional, ou em relação a países em desenvolvimento. Mais raras ainda são as contribuições que examinam as relações da UE com os BRICS como grupo, e como o posicionamento europeu na arena de comércio tem variado. Um renomado professor universitário recentemente fez mesmo uma exposição com o título "The EU and the BRICS: an oxymoron? "1. E no âmbito das instituições da União Europeia, são raros os documentos que

${ }^{1}$ (SRINIVASAN, 2014) 
enquadram esses países em uma estratégia do bloco para a transição de poder atualmente em curso na arena internacional.

Nesse sentido, fazem-se necessárias não só mais contribuições acadêmicas sobre esses dois grupos de países, e um posicionamento da UE no que se refere a novos grupos de potências emergentes na arena internacional - mas também um quadro conceitual que viabilize uma análise apropriada da ascensão de potências emergentes e seu impacto sobre a UE. Assim, a contribuição recente de Meissner (2016) - o Realismo Comercial - é um avanço bem-vindo nesse sentido - ao oferecer uma reinterpretação das obras de Carr (1939), Hirschmann (1969) e Gilpin (1981) - aplicada à política econômica externa da União Europeia. Esse trabalho centra-se no exame de fatores extra-regionais (coesão da região homóloga e competição com atores rivais) para investigar como a UE varia seu desenho de política externa.

Assim, Meissner testou as hipóteses realistas em oposição aos quadros teóricos institucionalista e do liberalismo comercial (variáveis intra-regionais). O realismo comercial tem "alavancagem analítica" para explicar a escolha de arenas de negociação pela União Europeia. No entanto, ficaram sem explicação os problemas de porque a UE mantém um desenho de negociação inter-regional quando a região homóloga é não-coesa, e do porque os atores institucionais europeus não demonstraram uma preferência clara pela arena bilateral ou inter-regional na arena de comércio. E igualmente, as etapas de negociação e ratificação dos acordos de livre-comércio não foram abordadas no estudo de Meissner. Sua obra avançou entretanto - enormemente na tarefa de investigar como fatores sistêmicos afetam o desenho de política comercial da União Europeia - e de descontruir a crença corrente na literatura de que o bloco europeu não seria reativo ao sistema internacional nessa arena.

Portanto, o objetivo desta tese foi analisar o posicionamento da UE em relação aos BRICS na arena de comércio, bem como de investigar porque a UE mantém um desenho de 
negociação inter-regional, em contradição com a expectativa do realismo comercial. Essa situação ocorreu no caso das negociações entre a UE e o GCC (Gulf Cooperation Council). Porém, tanto o GCC como os BRICS não ocupam um papel bem articulado no quadro da política externa da União Europeia - e o presente trabalho também teve como objetivo analisar comparativamente esses dois casos.

A entrada em vigor do Tratado de Lisboa em dezembro de 2009 gerou a expectativa de maior coordenação entre os diferentes domínios relacionados à política externa da UE, em especial a partir da criação da função do Alto Representante/Vice-Presidente para assuntos externos. No entanto, são raras as análises sobre as consequências desse desenvolvimento na arena de comércio - principalmente no que se refere ao uso de instrumentos de comércio para objetivos de política externa. Assim, traz-se uma contribuição à análise da atuação da UE no período pós-Lisboa, que também testemunhou a elaboração de um documento chave para a estratégia externa europeia: a European Union Global Strategy, de 2016. 


\section{Enunciado do problema e perguntas de pesquisa}

Embora o inter-regionalismo seja um princípio tradicional de política externa da União Europeia (UE), o bloco ainda não conseguiu concluir um único acordo de comércio nessa esfera. Dependendo do assunto em questão, a UE parece mais propensa do que antes a engajarse com atores pivôs no nível bilateral. Instâncias são abundantes em diferentes arenas de política - não apenas no comércio - mas também no que se refere ao meio-ambiente, energia e segurança. Renard (2016, p. 25). A maior parte dos acordos preferenciais de comércio da UE foi anunciada após 2006, entrou em vigor depois de 2013, ou ainda está sendo negociada. Ainda assim, ampliação de acordos dessa natureza, profundos e amplos, é uma característica peculiar da agenda da UE (ARAUJO, 2016; LECHNER, 2016; DÜR ET AL., 2014).

Em 1994 havia apenas 47 acordos de livre-comércio em vigor. Em 2000, esse número tinha aumentado para 93, e então exponenciou para 260 em 2013. A UE buscou um número de outros acordos nos anos 1990, mas, a fim de se focar na Rodada Doha, entre 2000 e 2006 implementou uma moratória em relação ao lançamento de novos APCs. O bloco agora já concluiu acordos com diversos países, e está em negociação com a Índia, os EUA e o Japão, entre outros. (AGGARWAL \& EVENETT, 2013, p. 551).

É possível distinguir entre dois tipos de estratégias internacionais discriminatórias de comércio da UE, isto é, entre aquelas de uma natureza inter-regional e de natureza bilateral. No caso da primeira, a UE atualmente mantém tanto "relações de parceria estratégica", "relações em base igual" ou outros tipos de relações comerciais com a maior parte das regiões do mundo (HANGGI 2006:35) Por outro lado, por um longo tempo, a estratégia bilateral da UE, desempenhou um papel secundário aos comprometimentos retóricos da UE com o multilateralismo e o inter-regionalismo (VAN LOON, 2009). 
No caso das relações da UE com o Mercosul, o reequilíbrio em favor do bilateralismo ficou evidente com a mudança de abordagem de um foco inter-regional, para uma estratégia bilateral, centrada no Brasil - consagrada com a parceria estratégica a partir de 2007. Nas negociações com o ASEAN, por sua vez, houve uma mudança de foco para negociações bilaterais com Cingapura e Vietnã, devida em grande parte à diferença de níveis de desenvolvimento entre esses países. Esses dois casos são de particular importância, pois tratamse de duas das mais avançadas experiências em integração regional fora da Europa, bem como de dois blocos de alto interesse estratégico para a UE.

Na prática, esse reequilíbrio está longe de ter estimulado o regionalismo sul-americano ou do sudeste asiático e o diálogo inter-regional. O bilateralismo seletivo desenvolvido pela UE em suas relações com as potências emergentes, elas mesmas inseridas em grupos regionais, se mostra contraditória com sua estratégia tradicional de promoção e exportação de seu modelo de integração regional e de governança regional. Isso suscita questões em relação à coerência da ação externa da UE, bem como a propósito da teoria que tende a considerar o bilateralismo como uma tendência complementar ao inter-regionalismo. (SANTANDER, 2017, p. 17)

Tanto o construtivismo quanto o liberalismo ideacional não explicam satisfatoriamente essa mudança de abordagem da UE na esfera comercial- e recentemente Meissner (2016) desenvolveu uma vertente da teoria realista, o Realismo Comercial para explicar esse problema empírico. O Realismo Comercial corrobora a relevância de atores rivais e da região homóloga na explicação de decisões de comércio do bloco (fase de elaboração do mandato de negociação). No entanto, esse modelo teórico não explica o posicionamento europeu na arena multilateral, ou a questão da compatibilidade das iniciativas bilaterais da UE com o inter-regionalismo e o multilateralismo. E embora o Realismo Comercial tenha trazido contribuição significativa para a compreensão de negociações inter-regionais e bilaterais de comércio da UE, ainda não foi 
realizado um levantamento abrangente de todas negociações, bem-sucedidas ou não, do bloco europeu (CONCEIÇÃO-HELDT, 2014; MEISSNER, 2017).

Esta tese insere-se na agenda de pesquisa das Relações Internacionais que aborda a política externa comercial europeia a partir de uma perspectiva realista e de teoria de negociações (AGGARWAL \& FOGARTY, 2004; FARRELL, 2005; HURT, 2003; LÁRSEN, 2016; MEISSNER, 2016; MEUNIER, 2005; ZIMMERMAN, 2007). Busca-se trazer uma contribuição original à disciplina, ao propor uma discussão a partir da abordagem do Realismo Comercial e da literatura referente à ação externa estratégica da UE. Assim, adota-se uma combinação de métodos qualitativos e estudos de caso (UE-BRICS, UE-GCC) para responder às seguintes perguntas de pesquisa:

A) Por que a UE tem feito uso crescente de instrumentos bilaterais na arena de comércio internacional?

B) Qual a inter-relação, a nível europeu, entre as políticas para as arenas bilateral, interregional e multilateral? como difere a formulação de política para essas diferentes arenas? 


\section{Natureza e originalidade do estudo}

As teses de McCrossan (2014) e Meissner (2016) representam alguns dos primeiros estudos comparativos de negociações comerciais no nível inter-regional. Este trabalho busca contribuir ao debate incipiente na literatura referente à influência de fatores externos sobre a Política Externa Comercial da UE, incluindo negociações na esfera plurilateral e com grupos de países emergentes.

Tradicionalmente, tendo em vista que as teorias realistas enfatizam o poder militar e a segurança, elas têm sido amplamente ausentes em estudos da UE. No entanto, recentemente têm sido incorporadas à pesquisa acadêmica sobre UE, principalmente na área de política externa e segurança (GEGOUT, 2005; HYDE-PRICE, 2006; SMITH, 2016). À exceção do trabalho de Zimmerman (2007) sobre a posição da UE em relação ao acesso da Rússia e China à OMC; do trabalho de Garcia (2012) sobre a política comercial da UE para a América Latina; ou da tese de Meissner (2016) sobre inter-regionalismo e bilateralismo no desenho de política comercial da UE, o realismo tem sido ausente desse campo de estudos.

Portanto, esta tese integra-se à linhagem de trabalhos (GARCIA, 2013; BURCKHARDT, 2013; SMITH, 2016; MEISSNER, 2016; 2017a; 2017b) que propõem uma explicação alternativa à corrente centrada em explicações a partir do modelo do agenteprincipal (DUR \& ELSIG, 2011; DE BIÈVRE \& ECKHARDT, 2011; CONCEIÇÃO-HELDT, 2011; 2017), que tem sido empregada para estudar a relação entre estados membros e a Comissão Europeia, bem como as preferências por arenas multilaterais ou bilaterais de regulação (ELSIG, 2007) - e enfatiza, portanto, o impacto de fatores enraizados no sistema internacional sobre a política comercial da UE.

A tese do Realismo Comercial (MEISSNER, 2016) testou o seu quadro teórico em contraposição ao liberalismo comercial e o construtivismo, deixando intocada a explicação, a 
partir de um conjunto complementar de teorias, como EMs (Estados Membros), grupos de interesse, atores rivais e a região homóloga influenciam o desenho de PEC. (MEISSNER, 2016, p. 27). Igualmente, o Realismo Comercial não explora casos de negociação na arena multilateral e aqueles em que a UE não entra em negociações e, conforme enfatizado anteriormente, por que em alguns casos as negociações da UE exibem uma configuração de soma-positiva, e em outros casos uma configuração de soma-zero.

Assim, esta tese traz uma contribuição original à área de Relações Internacionais ao testar elementos do Realismo Comercial, explorar questões não explicadas por esse modelo teórico e expandir o quadro analítico dessa abordagem, por meio da comparação entre negociações na arena inter-regional (incluindo coalizões) e bilateral (fase de elaboração do mandato). Igualmente, é analisada a questão da compatibilidade do bilateralismo crescente da UE com as abordagens do bloco nas arenas inter-regional, e multilateral de comércio.

À semelhança do estudo realizado por Meissner (2016) a unidade de observação - a respeito da qual dados e observações serão obtidos - que compõe a variável dependente desta tese consiste no mandato de negociação, concedido pelo Conselho Europeu à Comissão. Porém alguns elementos das rodadas de negociação também são analisados, justamente seguindo a recomendação de Meissner no que se refere a complementar a análise já feita pelo realismo comercial (do processo que leva à elaboração do mandato de negociação).

\section{Quadro teórico}

Meissner (2016) explica que o liberalismo ideacional e o construtivismo, baseados em fatores endógenos europeus, carecem de uma explicação direta do uso crescente da UE do bilateralismo e de sua incoerência aparente em relações comerciais externas. O liberalismo ideacional esperaria o multilateralismo abrangente como o instrumento de política externa da 
UE, assim liberalizando todos setores com o máximo de países em um acordo. De uma perspectiva construtivista, esperar-se-ia o inter-regionalismo como o principal instrumento de política externa, a partir da assunção de que essa ferramenta “desenvolveu-se em uma das fundações" (BORZEL \& RISSE, 2009) e a "doutrina de política externa" (HETTNE \& SODERBAUM 2005, p. 536) da Europa. Porque o liberalismo ideacional e o construtivismo não dão uma resposta direta ao porquê da mudança em direção ao bilateralismo, Meissner (2016) argumenta que o Realismo Comercial fornece alavancagem analítica para explicar essa mudança ao revelar o impacto de fatores externos.

A hipótese realista, inspirada por Schweller e Gilpin, prevê uma aderência forte a objetivos comerciais e geopolíticos, uma seleção estratégica de parceiros comerciais, e pouca ênfase em questões normativas e de grupos societais (SCHWELLER, 1999; GILPIN 2002; ANTKIEWICZ 2009, p. 229). Em resumo, o exato oposto do que é frequentemente chamado na literatura de poder "civil" (DUCHENE, 1973), ou "normativo" da Europa (MANNERS, 2002) (BURCKHARDT, 2013, p. 271). Essas duas abordagens têm sido predominantes nas análises sobre a EU. Daí a originalidade deste trabalho.

De acordo com a perspectiva do Realismo Comercial, a fim de incrementar a segurança econômica Europeia, a UE deve negociar acordos de comércio tais como AAs (acordos de associação), Parcerias Estratégicas, ou acordos preferenciais de comércio (APCs). Quando tais acordos também são negociados pelas grandes potências, a UE compete com eles para firmar um acordo com o parceiro respectivo. Nessa situação, negociações simultâneas podem se tornar um jogo de soma-zero porque um acordo com a UE pode impedir um acordo paralelo com outra grande potência. Ao aumentar a probabilidade de chegar a um acordo, a UE ajusta o desenho de sua política comercial externa (PEC) a características da região homóloga, especialmente no que se refere a sua coesão (MEISSNER, 2016, p. 55) 
Enquanto fatores externos à UE parecem ter poder para explicar o desenho do mandato de negociação, fatores internos à UE parecem ter poder explicativo para rodadas de negociação e a substância de eventuais acordos. (MEISSNER, 2016, p. 315). Assim, o contexto internacional de qualquer negociação da UE importa, e as características do parceiro de negociação em relação à UE claramente têm um impacto na dinâmica de negociação (DA CONCEIÇÃO-HELDT \& MEUNIER, 2014). Essa organização tem geralmente sido vista como um negociador muito poderoso e influente com forte capacidade institucional e memória, que junto com sua força econômica tem dado a ela uma vantagem significativa sobre muitos de seus parceiros de negociação (WOOLCOCK, 2005, p. 297) (LARSÉN, 2017, p. 18).

Na política comercial, uma vez que os processos de barganha e agregação de interesses são completados, a UE age como uma entidade unitária nas negociações internacionais. Isso justifica uma análise a nível da UE e facilita a aplicação de conceitos (neo)realistas. À medida que a política comercial do bloco se torna crescentemente preocupada com a competição econômica e com o equilíbrio contra possíveis vantagens comerciais negociadas por outras partes, uma abordagem realista, integrando interesses comerciais, torna-se apropriada para este estudo. (GARCIA, 2013, p. 524).

Empiricamente, é questionável se a principal motivação da UE para o inter-regionalismo com o ASEAN (Associação dos Países do Sudeste Asiático), CAN (Comunidade Andina de Nações) e o GCC (Gulf Cooperation Council) foi encontrar base comum para negociações de comércio paralelas ou futuras. No caso do ASEAN, foi a suspensão da rodada Doha (2008), em conexão com a conclusão de um FTA pelo Japão com a região, fora da $\mathrm{OMC}$, que levou à decisão da UE de considerar conversas puramente regionais com esse grupo (ROBLES, 2008, P. 542). No caso da CAN, por outro lado, a UE inicialmente colocou como condição para negociações inter-regionais, a conclusão da rodada Doha. Obviamente, não satisfazendo essa condição, a UE começou negociações puramente inter-regionais com a região em 2007. E no 
caso da GCC, é improvável que a UE tenha perseguido o inter-regionalismo puro com a região em uma tentativa de resolver questões em um nível menor que o multilateral (MEISSNER, 2017).

\section{Metodologia}

Tendo em vista que estudos informados por teoria são relativamente raros na área de estudos sobre UE, ainda observamos um déficit no campo da metodologia. A função principal da metodologia - viabilizar encontros entre teoria e empiria - não pode ser rigorosamente feito sem teoria. (JORGENSEN, 2015, P.10). Esta pesquisa visa dar uma contribuição original ao campo de Relações Internacionais, notadamente na compreensão das estratégias da UE em relação a potências emergentes, por meio de uma perspectiva que combina teorias de relações internacionais e estudos de caso. Nesse sentido, os objetos centrais deste estudo consistem em: 1) a compatibilidade do novo bilateralismo da UE com o regionalismo e multilateralismo; 2) reequilíbrio na estratégia de negociação comercial da UE, de uma abordagem multilateral e regional para bilateral. 3) a existência de similaridades e diferenças em negociações (de comércio) nos âmbitos inter-regional e bilateral, de uma perspectiva de formulação de política da UE.

Chamados recentes têm sido feitos para que os estudos das relações de comércio e desenvolvimento da UE com o sul global movam-se para além de um foco estreito nos APEs (Acordos de parceria econômica) e nos países do ACP (África, Caribe e Pacífico) (CARBONE \& ORBIE, 2014). Assim, seguindo a recomendação de Murray-Evans (2014), esta tese também busca, por meio de uma abordagem comparativa, estudar a maneira pela qual as projeções externas da UE são articuladas e perseguidas dentro de uma variedade de contextos, incluindo relações com diferentes países parceiros e regiões. 
O estudo de caso comparativo foi considerado a abordagem mais útil e apropriada, porque permite a identificação de padrões regulares de comportamento (LIJPHART,1971) e o objetivo central do estudo foi fazer um estudo comparado no que se refere às relações da UE com grupos de países emergentes. Reunindo arenas e questões de negociações de comércio em um quadro analítico, a UE pode variar o desenho da PEC ao longo de quatro resultados: uma arena inter-regional e um conjunto abrangente de questões; uma arena inter-regional e um conjunto seletivo de questões; uma arena bilateral e um conjunto abrangente de questões; uma arena bilateral e um conjunto seletivo de questões ${ }^{2}$. (MEISSNER, 2016, p. 42). Assim, enfatizase a hipótese derivada do Realismo Comercial: se os fatores extra regionais, que são relações comerciais dos atores rivais com a região homóloga, e a força coesiva dessa região, constrangem o poder econômico da UE, ela mudará o desenho de sua política externa comercial em favor de competir com êxito com atores rivais e reagir às características mais importantes da região homóloga. (MEISSNER, 2016, p.54).

Porém, casos de negociação na arena minilateral ${ }^{3}$ também foram analisados complementando o trabalho acadêmico já realizado na área e ao mesmo tempo trazendo uma contribuição para o mapeamento extensivo de negociações da UE - ainda não realizado (Conceição-Heldt, 2014, Meissner, 2016). À semelhança do estudo pioneiro de Meissner (2016), esta tese adota o desenho de política comercial da UE como a variável dependente. Como variáveis independentes, mantem-se duas variáveis do Realismo Comercial (região

\footnotetext{
${ }^{2}$ Além das dimensões multilateral e bilateral de política comercial - em grande medida "liberalizantes" - a UE pode adotar medidas mais protecionistas de defesa comercial por meio da dimensão unilateral. Assim, a Comissão pode propor a adoção de determinadas medidas protetivas, das quais medidas antidumping são as mais importantes, que devem ser adotadas pelos Estados Membros no Conselho. Esse procedimento é desempenhado pelo Diretorado de Defesa Comercial do DG Comércio, que é considerado mais "protecionista" que a média ideológica do DG Comércio e tem uma tendência de alinhar-se com produtores pedindo proteção (YOUNG \& PETERSON, 2014) (BOLLEN ET AL. 2016, p. 282)
}

${ }^{3}$ Conforme a definição de Aggarwal (2009) 
homóloga e atores rivais ${ }^{4}$ ), porém adaptadas a fim de incorporar a estratégia da UE em relação a coalizões de potências emergentes. E como variáveis independentes intra-regionais, são analisados o nexo entre a política comercial e política externa da UE; bem como as preferências das instituições da UE.

Tendo o Realismo Comercial identificado atores rivais e a região homóloga como fatores explanatórios para o mandato de negociação, e tendo indicado EMs (Estados Membros) da UE e GIs (Grupos de Interesse) como atores relevantes nas rodadas de negociação, enfatizase a distinção entre três passos analíticos, a partir da recomendação de Meissner (2016): (a) a fase para desenhar o mandato de negociação, (b) a fase de rodadas de negociação, (c) a ratificação do acordo e seu conteúdo. No entanto, conforme já explicado anteriormente, o foco principal desta tese é no primeiro desses três passos analíticos, por limitações de tempo e recursos.

Do ponto de vista teórico, este trabalho também busca trazer uma contribuição à tese do Realismo Comercial, por meio da análise do desenho de política para coalizões de paísescomplementando assim a explicação para os resultados obtidos nas arenas inter-regional e bilateral. Em termos mais específicos, testar a validade da hipótese de que os atores rivais (e a coesão da região homóloga) tem valor explicativo para o desenho de política também para coalizões de países emergentes. O refinamento teórico do Realismo Comercial também será viabilizado por uma análise mais aprofundada do caso de negociações UE-GCC, em que houve

\footnotetext{
${ }^{4}$ McCrossan (2014, p.16) trabalha com o conceito de fatores sistêmicos, focando-se nos desafios e oportunidades apresentados pelo sistema internacional. Diversos estudos têm considerado a utilização do inter-regionalismo pela UE como um mecanismo para responder a desenvolvimentos no nível internacional por meio de comportamento de equilíbrio e construção de instituições. Equilíbrio (balancing) refere-se à idéia de que a Comissão, agindo em nome dos Estados Membros, desenvolveu uma rede de relações com organizações regionais em outras partes do mundo a fim de aumentar as capacidades da UE como um ator econômico e de política externa (RULAND, 2010)
} 
a manutenção de um desenho de negociação inter-regional, contrariando a expectativa daquela tese.

\section{Estudos de caso e justificativa}

À semelhança do trabalho de McCrossan (2014), a decisão de adotar um estudo de caso qualitativo ao invés de conduzir uma análise quantitativa de n-grande de todo o espectro das negociações inter-regionais da UE justifica-se pelo número pequeno dessas tratativas em que negociações de APCs tem ocorrido. Igualmente, a abordagem qualitativa enquadrou-se melhor ao objetivo de sublinhar a variação no processo de tomada de decisão em termos de política comercial.

Como estudo de caso primários apontam-se as negociações UE-GCC ${ }^{5}$ (GCC, Gulf Cooperation Council na sigla em inglês), em que houve a manutenção de uma abordagem interregional de negociações para um acordo de livre-comércio; e a política comercial da UE para os BRICS. Como estudos de caso secundários foram escolhidas as negociações UE - Mercosul, e o caso das negociações da UE com os EUA para a assinatura da Parceria Transatlântica de Comércio e Investimento (TTIP, na sigla em inglês).

A escolha das negociações UE- Mercosul deve-se à identificação de um processo de mudança de foco da UE, de uma abordagem inter-regional, para uma estratégia bilateral de parceria estratégica com o Brasil - mesmo levando em consideração que o Mercosul é um dos projetos de integração regional mais relevantes do mundo (MEISSNER, 2016). Da mesma

${ }^{5} \mathrm{O}$ caso das negociações UE-GCC justifica-se, essencialmente, pela decisão europeia de manter um desenho de negociação inter-regional com os países do GCC, mesmo levando-se em consideração a falta de coesão entre esses países - ou seja, contrariando a expectativa teórica do Realismo Comercial. E também se enfatiza que esse caso diverge daqueles observados para o caso das relações da UE com o ASEAN e a CAN - para não mencionar ausência de uma estratégia clara da UE para esse grupo de países, à semelhança do que ocorre com os BRICS. 
forma, o Mercosul é de importância estratégica para a União Europeia não apenas no domínio de política comercial, mas também para os objetivos mais amplos da UE de presença e capacidade de atuação global (ARANA, 2014).

O caso das negociações da UE no âmbito do TTIP justifica-se pelo fato de a UE ter, a partir de 2009 - ano que marca o fracasso das negociações na esfera multilateral - mudado sua estratégia no que se refere ao posicionamento em relação a países emergentes (ASEAN, Índia, e Coréia do Sul), e buscado acordos com os membros do antigo "quad” (EUA, Japão, Canadá). Em outras palavras, até 2008 o sistema multilateral de comércio guiou as iniciativas da UE, ao passo que, a partir de 2009, a busca por acordos bilaterais passou a ser vista como um substituto para o sistema multilateral (ou no caso do TTIP, como "contra-multilateralista") (GARCIADURAN, 2016). Igualmente, as negociações na esfera dos mega-acordos regionais viabilizam um exame mais aprofundado da interação da UE com atores rivais, bem como com os parceiros estratégicos do bloco. 


\section{Limites às abordagens teórica e metodológica}

Como se sabe, a meta-teoria materialista e individualista em que o realismo e o racionalismo se baseiam, e o tratamento de preferências e interesses como exógenos e individualistas tem sido fortemente criticados (GARCIA, 2013). Explicações enfatizando ideias tem emergido como rivais à ênfase racionalista em preferências (GOLDSTEIN \& KEOHANE, 1993). Conforme Garcia (2013, p. 524) sublinha: “essa rivalidade sugere que os interesses não são eles mesmos ideias, mas materiais", mas mesmo os "economistas já notaram que nada na abordagem deles impede considerar os desejos (ou interesses ou preferências), como sendo informados por, ou baseados em normas" (FEARON \& WENDT, 2002, p. 60). Assim, a interação entre ideias e interesses seria, portanto, uma tensão dinâmica

Uma explicação da política comercial da UE a partir de uma perspectiva realista não se pretende ser uma bala de prata- para usar uma expressão recentemente avançada por Smith (2016) - mas enfatizar a influência de mudanças na economia internacional sobre essa esfera da atuação da UE. E igualmente, salientar que a UE tem sido muito mais reativa ao sistema internacional do que o mainstream de relações internacionais está disposto a admitir, em acordo com a proposição do Realismo Comercial e outros estudos dessa vertente teórica (ZIMMERMAN, 2007; MEISSNER, 2016; 2017; WIGELL, 2016).

Este trabalho parte da perspectiva de Aggarwal \& Evenett (2013) que conceitua os estados como atores unitários na governança do comércio global que detém interesses políticos e econômicos exogenamente determinados, e que mudam entre arenas preferenciais e multilaterais de acordo com onde eles esperam alcançar seus objetivos de forma mais bemsucedida (MEISSNER, 2016).Teórica e empiricamente a literatura acadêmica já modelou a UE como um ator unitário, e atribuiu a ela um interesse coletivo na arena internacional(MEISSNER, 2016; 2018). Vários estudos (BORZEL, 2015; ELGSTROM \& 
LARSÉN, 2010; MEUNIER, 2007; STRANGE, 2015; ZIMMERMAN, 2007) fornecem evidência empírica que apoiam a assunção de ator em negociações comerciais.

No entanto, a literatura já demonstrou que os Estados com que a UE negocia claramente sabem que a UE não é como um Estado-nação, e, portanto, veem-na mais como um facilitador do processo de negociação, e não como um ator hegemônico. Isso, portanto mina o poder da UE na governança do comércio global e os parceiros do bloco prestam atenção cuidadosa não apenas ao que a Comissão ${ }^{6}$ quer, mas também aos desentendimentos entre os Estados-membros (STRANGE, 2015). Em outras palavras, a compreensão da UE como um ator unitário também precisa ser qualificada, levando em consideração que o bloco também desempenha outros papéis, por exemplo como uma ferramenta de dominação (por meio da ação de elites), ou como uma arena de contestação.

Igualmente, uma tensão inerente aos estudos de caso consiste na possibilidade de obter maior validade interna, em detrimento de uma generalização para uma população maior (BENETT, 2005; CONCEIÇÃO-HELDT, 2014; KERSSCHOT, 2016). Conforme Ragin (1987, p. 69) enfatiza, a principal fraqueza da estratégia orientada para casos "é sua tendência a particularizar (com frequência ao mesmo tempo em que almeja maior generalidade - por exemplo uma teoria de mobilização política étnica baseada em um caso); a principal fraqueza da estratégia orientada para variável é sua tendência a generalizações abstratas, e, às vezes, vazias”. Porém, os estudos de caso permitem testes mais fortes e numerosos do que estudos de n-grande. (VAN EVERA, 1997, p. 30).

\footnotetext{
${ }^{6}$ A Comissão da União Europeia emprega mais de 28000 indivíduos - dos Comissários a trabalhadores de arquivos. Eles estão espalhados por 45 Diretorados-Gerais (DGs) e serviços (Comissão, 2016). Politicamente, a Comissão é representada por 28 Comissários com diferentes backgrounds nacionais e ideológicos de estados membros "novos" e "velhos" que falam pelo menos 24 línguas. Apesar dessa diversidade enorme, a "Comissão" tem sido retratada no mundo acadêmico como um ator unitário. (GASTINGER, 2017, p. 181)
} 


\section{Validade e confiabilidade do estudo}

O emprego de uma abordagem realista para a análise da política externa da UE deve considerar o fato de não se tratar de um ator unitário. Mas também é preciso considerar o bloco como um ator internacional que produz uma política externa. No contexto pós-Lisboa, a habilidade da UE de gerar política externa foi melhorada com a formação de um corpo diplomático, o European External Action Service (SEAE, na sigla em português); a criação de duas posições para melhorar a visibilidade e status da UE internacionalmente ${ }^{7}$; e a ampliação das competências exclusivas e compartilhadas da União. (SMITH, 2016, p. 30).

De certa forma, testar a teoria realista na atuação econômica externa da UE representa um caso menos provável (least likely case), porque a teoria teria maior validade para assuntos de high politics como questões militares ou de segurança (Meissner, 2016). No entanto, na ausência de poder militar, a UE tem poder econômico significativo à sua disposição. Importantemente, o comércio, e também crescentemente investimento externo direto é uma das maiores áreas de competência da UE. Oficialmente a Comissão Europeia negocia acordos externos de comércio em nome dos estados membros. Como consequência, e de acordo com Meunier \& Nicolaidis (2009), a UE tornou-se, internacionalmente, "um poder por meio do comércio", que usa esse poder "para alcançar objetivos não comerciais". Assim, conforme Smith (2016, p.31) enfatiza, embora ser apenas uma potência econômica certamente iniba o escopo e efetividade da política externa da UE, ter um poder econômico tremendo é, no entanto, útil para perseguir objetivos internacionais e, em alguns aspectos, é mais fácil de aplicar do que o poder militar tradicional.

\footnotetext{
${ }^{7}$ Com o Tratado de Lisboa, foram criadas as posições de alto representante da UE/Vice Presidente da Comissão e a de Presidente do Conselho.
} 
Empregar uma abordagem realista para analisar a política externa da UE também foge à conceitualização popular da UE como representando algo como um ator internacional pósmoderno e/ou post-Westfaliano. Conforme Smith (2016) sublinha: “de fato, a política externa da UE, comparativamente àquela de um Estado, é mais conspicuamente, embora talvez apenas ostensivamente, influenciada por fatores ideacionais e normativos". O foco majoritário nesse aspecto ideacional da política externa da UE tem resultado na marginalização da análise de variáveis sistêmicas e materiais como condutores da ação da UE. (idem, p. 31).

\section{Argumento teórico}

$\mathrm{O}$ argumento central desta tese consiste em que a UE adapta sua política comercial em resposta a fatores extra regionais, isto é, atores rivais e região homóloga, porém esses fatores também estão condicionados à estratégia de política externa europeia. Desta forma, os elementos enfatizados pela tese do Realismo Comercial (Meissner, 2016) também devem ser entendidos em seu aspecto mais amplo dos objetivos (geo)políticos da UE em suas relações com regiões terceiras. Na linha do que argumenta o Realismo Comercial, esta tese defende a proposição de que a política comercial da UE é muito mais reativa a fatores sistêmicos do que a literatura de relações internacionais está pronta a admitir.

Também se avança a ideia de que o uso crescente de instrumentos bilaterais pela UE não representa um distanciamento da política externa tradicional da UE. Os atores da UE têm enfatizado a diversidade de agendas no relacionamento europeu com países e regiões terceiras, e - mais especificamente na arena comercial - a quantidade crescente de negociações tem colocado pressão maior sobre os oficiais da DG Comércio. Desta forma, os princípios centrais da ação externa do bloco estão preservados, e a complexidade crescente da governança global do comércio refletem-se nas preferências dos atores institucionais do bloco. 
Em suas décadas iniciais de existência, a UE não dispunha de um aparato diplomático que funcionava em coordenação com as demais instituições europeias - fato que, ainda que de maneira incipiente, foi alterado com a assinatura e entrada em vigor do tratado de Lisboa em 2009 (SUS, 2017; BOSSUYT ET AL, 2018). Assim, a corrente teórica do inter-regionalismo tem enfatizado a preocupação central da UE em exportar seus valores centrais para regiões terceiras - democracia, respeito aos direitos humanos, desenvolvimento. No entanto, conforme Meissner sublinha, poucos trabalhos têm pesquisado as negociações entre a UE e organizações entre países em desenvolvimento, além de estudos de caso único.

A política comercial do bloco é essencialmente supranacional e centralizada, e, portanto, podemos considerar a UE como um ator unitário que responde a estímulos do sistema internacional - principalmente a competição com outros grandes atores por recursos e regiões terceiras. No caso das potências emergentes, uma forma de que se utilizam para contrabalançar o poder de grandes atores consiste na formação de coalizões. Desta forma, o que no quadro teórico do Realismo Comercial é conceitualizado como um ator rival, pode igualmente competir com a UE diretamente (e não em regiões terceiras), por meio da ação coordenada com outros atores.

A UE monitora o surgimento e atuação desses grupos de países, reagindo ou não por meio da adoção de políticas específicas, por exemplo para os domínios do meio ambiente, segurança e comércio (UJVARI, 2014). Porém, tendo em vista o foco tradicional do aparato da DG Comércio em regiões, não presta atenção específica a grupos de potências emergentes nesse domínio de ação externa. Em termos mais específicos, isso significa que a UE não dispõe de um mandato de negociação para um acordo de livre comércio com esses grupos.

No que se refere aos instrumentos utilizados nas esferas inter-regional e bilateral de comércio, o argumento aqui avançado é que fatores políticos podem engendrar a manutenção 
de um formato inter-regional de negociações, mesmo quando as características da região homóloga justificariam a mudança para um mandato bilateral. Essencialmente, trata-se de uma resposta à atuação de atores rivais em regiões terceiras, mas que também leva em consideração a preferência de instituições da UE, conforme ficou evidenciado no caso empírico das relações UE-GCC.

Em síntese, a ausência de uma estratégia clara da UE para as transformações em curso na arena internacional pode representar um problema para o futuro do bloco (KEUKELEIRE \& DE BRUYN, 2017). Assim, a competição com atores rivais e características da região homóloga devem ser analisadas em conjunto com fatores domésticos do bloco, para uma compreensão mais aprofundada dos processos que marcam a fase de pré-negociação de acordos de livre comércio. E adicionalmente, a combinação desses níveis de análise também é apropriada para uma melhor compreensão da ação estratégica da UE. 


\section{Estrutura do trabalho}

Após esta introdução, o primeiro capítulo traz uma análise da bibliografia referente à política externa comercial da UE, em especial no que se refere ao estado da arte na disciplina, e aspectos dos níveis doméstico, institucional e internacional da economia política das relações comerciais da UE.

Já o segundo capítulo, de natureza teórica, enfatiza os principais conceitos e ferramentas teóricas a serem utilizados no estudo. Isto é, uma explicação e crítica dos elementos centrais da abordagem do Realismo Comercial, abordagem teórica que reformula o realismo a fim de explicar a variação na política externa comercial da UE. Igualmente, são apresentadas e explicadas as hipóteses do trabalho.

O terceiro capítulo traz uma discussão sobre os aspectos de epistemologia e ontologia da tese, bem como apresenta a operacionalização das variáveis dependente e independentes, apresentando também o desenho de pesquisa adotado na análise empírica dos casos A segunda parte desse último capítulo compreende uma análise comparativa dos casos, a fim de trazer contribuição à explicação da mudança de ênfase da UE, de uma abordagem inter-regional, para bilateral em sua PEC - bem como no que se refere à política do bloco para coalizões de potências emergentes.

E, por fim, apresentam-se as conclusões do estudo e direções para pesquisa futura. 


\section{CAPÍTULO 1}

\section{Revisão da literatura: O debate sobre política externa comercial da UE}

\subsection{Definição de política externa e política comercial}

A partir da concepção de Hill (2003, p. 17), é possível afirmar que a política externa (europeia) trata da "questão fundamental de como grupos organizados, pelo menos em parte estranhos uns aos outros, se inter-relacionam”. Ou, como Hill \& Wallace (1996, p. 12) colocam “a política externa da UE é um sistema intensivo de relações externas, em que os atores em cooperação que constituem o sistema se entrelaçam”. E mais especificamente no domínio de política comercial $^{8}$, também pode-se entender a ação externa desse bloco como um instrumento para alcançar objetivos de política externa.

Em linha com o discurso da UE, incluindo a Estratégia de Segurança Europeia (2003, 2008) e a Estratégia Global da UE (2016), e conforme Bossuyt et al. (2018, p. 2) enfatizam, objetivos de "política externa" são definidos amplamente para incluir considerações geopolíticas, bem como valores normativos tais como multilateralismo, direitos humanos e padrões trabalhistas (BISCOP, 2005; KALDOR ET AL. 2007; BOSSUYT ET AL. 2013; TOCCI, 2017).

\footnotetext{
${ }^{8}$ Os objetivos centrais da política comercial da UE estão delineados no artigo 206 do TFEU, que afirma que a UE deverá "contribuir, no interesse comum, ao desenvolvimento harmonioso do comércio mundial, a abolição progressiva de restrições ao comércio internacional e ao investimento estrangeiro direto, e à redução de taxas alfandegárias e outras barreiras". A PCC (Política Comercial Comum) deve também se conformar aos objetivos externos gerais da UE conforme estabelecidos no Artigo 21 do Tratado da UE. Esses incluem objetivos normativos gerais, tais como promover a democracia, o estado de direito e os direitos humanos, a preservação da paz e da boa governança e - com referência mais específica ao comércio e investimento - a forjar o desenvolvimento econômico, social e ambiental dos países em desenvolvimento de uma forma sustentável, com o objetivo de erradicar a pobreza e encorajar a integração de todos os países à economia global, inclusive por meio da abolição progressiva de restrições ao comércio internacional" (TFEU Art 21 (d) e (e)) (WOOLCOCK, 2014, p. 39)
} 
Bossuyt et al. (2018) também chamam atenção para a divisão institucional-ideacional entre os subsistemas de política comercial e externa, no sistema de política da UE:

"Pesquisando os nexus de comércio-desenvolvimento e segurançadesenvolvimento da UE, respectivamente, Pilegaard (2009) e Olsen (2009) observam como os subsistemas de comércio e segurança na UE operam de acordo com seus próprios procedimentos padrão. Similarmente, no que concerne a abordagem abrangente da UE para segurança, Gebhard e NorheimMartinsen (2011) argumentam que " a tensão reside no espírito de corpo (às vezes em conflito) dos vários atores institucionais da UE envolvidos". Essa tensão institucional reflete a tensão básica entre puristas do comércio (incluindo oficiais do comércio) e especialistas de política externa (incluindo diplomatas): "para os puristas, os objetivos de política externa da UE invadem, como não deveriam, a política comercial, que deveria ser utilizada estreitamente para defender interesses econômicos europeus". Os formuladores de política comercial da UE tendem a assumir que o comércio é um instrumento muito estreito para encaminhar assuntos complexos de política externa e de segurança, e que isso seria mesmo contraproducente. Os especialistas de política externa, por sua vez, consideram o comércio como uma ferramenta de política para a UE perseguir seus objetivos de política externa (PETERSON, 2007)”

Nesse sentido, a perspectiva adotada nesta tese não é aquela dos "puristas", mas sim uma que considera a política comercial da UE como um dos instrumentos da ação econômica externa do bloco. Essa ação da UE pode se dar nas arenas multilateral, inter-regional, bilateral, ou a UE pode decidir não entrar em negociação nenhuma, conforme sublinha Meissner (2016), vide figura abaixo. No entanto, essa é apenas uma simplificação dos diferentes arranjos em que o bloco se engaja com outros atores na arena do comércio internacional, e que, conforme retomaremos no capítulo metodológico da tese, frequentemente dificulta o estabelecimento de valores para a variável dependente (AGGARWAL, 2009). 
Figura 1: Conceituação da política comercial externa da UE, segundo o esquema proposto por Meissner (2016).

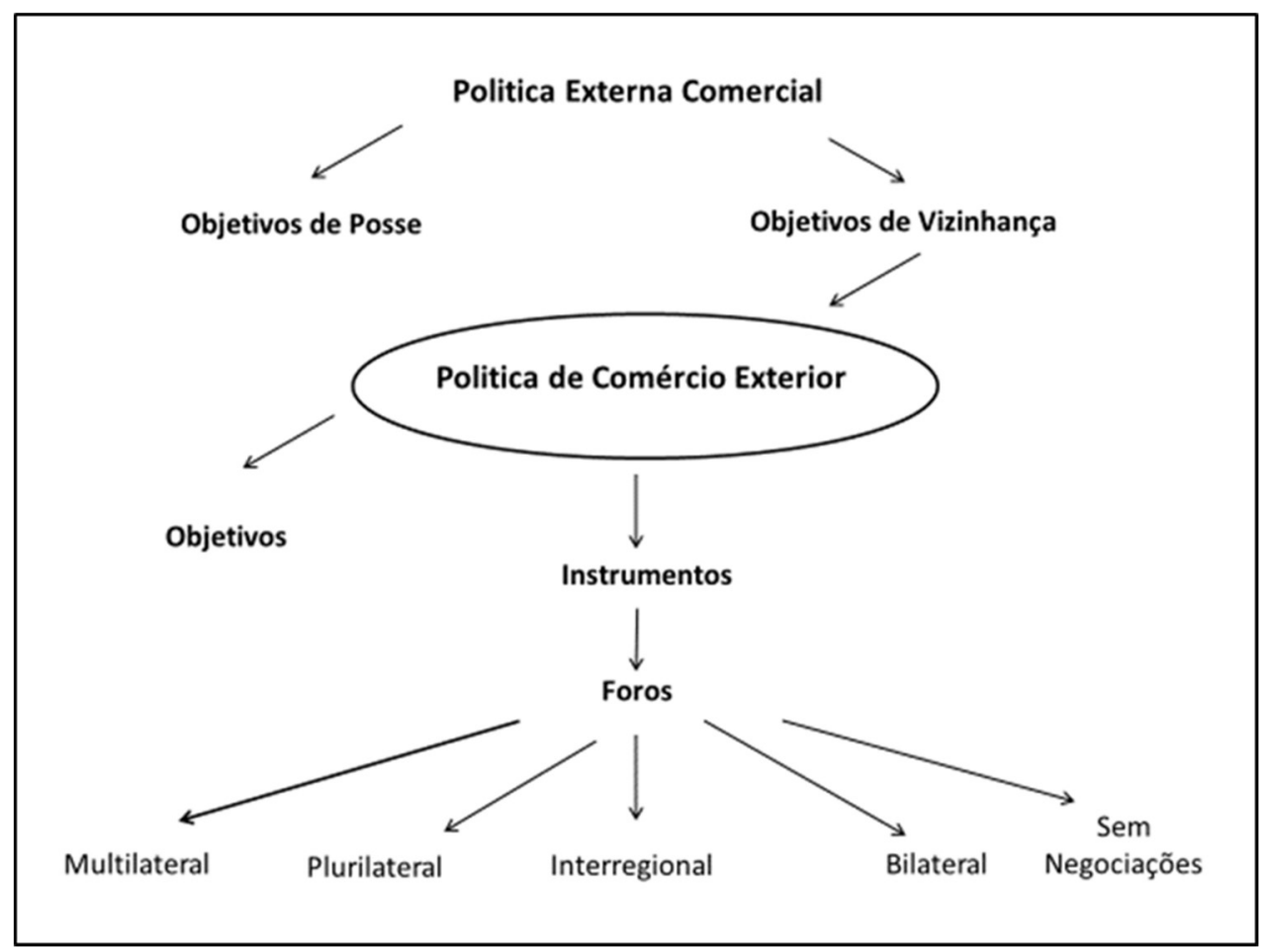

Fonte: Meissner (2016, p. 42)

De acordo com a Comissão Europeia, a política comercial revitalizada da UE (a partir da estratégia Trade for All, de 2015) deveria basear-se em três pilares: efetividade, transparência, e exportação dos valores da UE para o resto do mundo. Efetividade significa que a política comercial da UE se tornará mais orientada para resultados, focando-se na facilitação de cadeias de valor, a inclusão de comércio digital em negociações prospectivas, e a facilitação das regras que governam o movimento de profissionais altamente qualificados. O segundo pilar da nova política comercial da UE foca-se na importância da transparência como um componente importante de um esforço de aumentar a legitimidade e confiança da UE ao lidar com interesses nacionais importantes dos estados membros da UE. O terceiro pilar da nova abordagem em comércio reside na ideia de que os valores da UE poderiam ser 'exportados' por meio de negociações de comércio. Alguns analistas argumentariam que a promoção de seus 
valores e ideais é a característica distintiva da ação externa da UE. (DELIMATSIS, 2017, p. 585)

\subsection{Estado da Arte}

Embora a UE possa ser descrita como a organização internacional ${ }^{9}$ mais poderosa e proeminente do mundo, o estudo da UE não está bem integrado à - de fato, parece crescentemente segregada da - pesquisa acadêmica mais ampla em Relações Internacionais (GEHRING, 2017; PHELAN, 2012). No entanto, trabalhos no âmbito de política comercial da UE são os que mais se aproximam do objetivo de integrar o estudo do bloco à literatura mais ampla da disciplina (POLETTI \& DE BIÈVRE 2014)

O estudo de política comercial da UE tem tradicionalmente vinculado-se a três disciplinas: política comparada; economia política internacional e relações internacionais. Os trabalhos da última vertente, mais especificamente, têm recebido forte aporte da tradição realista e da teoria de negociação, a exemplo da obra de Aggarwal \& Fogarty (2004) que sublinha os objetivos geo-estratégicos ${ }^{10}$ da UE em negociações interregionais, tal como contrabalancear a reemergência da Ásia ou o poder dos EUA (DE BIĖVRE \& POLETTI, 2013). Zimmerman (2007) igualmente se baseia em explicações baseadas no realismo, quando ele

9 De acordo com esses debates, as características particulares que fornecem a base para a UE ser uma potência agora variam da "Potência Pequena" (TOJE, 2011), à disjunta "Potência Fragmentada" (SAPIR, 2007), à "Potência Aversa-ao-risco" (LAIDI, 2010), à, talvez a mais proeminente, a ideacionalmente influente "Normative Power Europe" (MANNERS, 2002) e o projeto Transformative Power of Europe. (DAMRO, 2015, p.3). Outra linhagem de trabalhos, no entanto, não considera a UE como uma organização internacional (HERITIER \& PRAKASH, 2015): ela poderia ser vista como uma confederação em formação, ao invés de uma organização intergovernamental tradicional.

${ }^{10} \mathrm{O}$ inter-regionalismo tornou-se um componente forte das relações da UE com a América Latina, Ásia e África. No entanto, o inter-regionalismo não é o princípio guiador das relações da UE com a América do Norte, nem daquelas com os países da Europa Central ou do Leste. (SODERBAUM ET AL, 2005, p.366) 
argumenta que a UE foi motivada por considerações geo-econômicas e mercantilistas em suas negociações sobre o acesso da China e da Rússia à OMC.

Da mesma forma, alguns autores analisam o engajamento da UE com os países ACP no quadro dos Acordos Europeus de Parceria como um exercício de política de poder (HURT, 2003; FARRELL, 2005). Meunier $(2000,2005)$ estuda como diferentes regras institucionais para agregar preferencias divergentes dos Estados-Membros em uma posição comum afetam as capacidades de barganha da UE em negociações internacionais de comércio, contribuindo significativamente para a teoria de negociação ao jogar luz sobre o link entre estruturas institucionais domésticas e efetividade externa em negociações internacionais (POLETTI \& DE BIÈVRE, 2013, p. 108).

Orbie \& Kerremens (2013) apontam que a maior parte dos trabalhos sobre as políticas comerciais da UE são organizados ao longo de linhas temáticas: novas questões relacionadas ao comércio; negociações comerciais externas da UE; a ligação entre aspectos sociais e de comércio; e sobre o nexo entre comércio e desenvolvimento. No entanto, a atenção a diferentes paradigmas no estudo das políticas comerciais da UE tem sido mais implícita do que explícita. Poucos autores tendem a engajar-se explicitamente em um debate sobre diferentes paradigmas em sua busca por uma explicação de processos ou resultados de política comercial na UE.

De qualquer forma, mais recentemente o campo de pesquisa sobre política externa comercial da UE tornou-se muito dinâmico, e agora existe um debate intenso na literatura sobre explicações centradas no estado ou na sociedade (ECKHARDT \& POLETTI, 2015), sobre a relação entre questões políticas e econômicas (vide a edição especial recente de Contemporary Politics "Perspectives on the trade-development nexus in the European Union") e sobre a mudança em direção a métodos quantitativos (DUR et al., 2014) (MEISSNER, 2016, p. 39). E também no que se refere a questões regulatórias, com a publicação da edição especial do Journal 
of European Integration (Vol. 39, 2017) "Writing the rules of 21 st century trade: the EU and the new trade bilateralism".

Assim, há um debate sobre como a UE comporta-se como um ator na governança global do comércio, particularmente tendo em vista a forte ênfase em normas progressivas dentro de boa parte da política da UE, incluindo direitos trabalhistas e desenvolvimento sustentável. A pesquisa acadêmica recente tem tendido a enfatizar o viés realista da política comercial da UE, mudando de uma abordagem mais normativa (ADRIANSEN \& GONZÁLEZ-GARIBAY, 2013; GARCIA, 2013; ZIMMERMAN, 2007). Isso tem sido presente tanto em como a UE comporta-se na OMC e outros aspectos de sua política externa comercial, incluindo parcerias econômicas. Para alguns, isso não é um fenômeno novo, com Dur (2008) apontando para o papel histórico que os interesses econômicos têm desempenhado sobre as normas, desde que a Comunidade Europeia primeiramente apareceu como um ator na governança global do comércio (STRANGE, 2015, p. 887).

Em síntese, o desenvolvimento da UE como um ator multifacetado tem suscitado literatura crescente a respeito da ação econômica externa do bloco. Conforme Zimmerman (2017) enfatiza, esses trabalhos têm buscado responder a duas questões principais: como a UE chega a suas posições na arena internacional? Como o bloco tem garantido a realização de suas preferências em barganhas com parceiros internacionais? (CONCEIÇÃO-HELDT, 2014; VAN SCHAIK, 2013)

\subsection{Lacuna na pesquisa acadêmica}

O conhecimento limitado a respeito das constelações multilaterais e da China, Índia, Brasil, e outras potências emergentes (certamente em comparação com os EUA) - tanto nas estruturas de política externa da UE e de estados membros e em universidades e centros de 
pesquisa europeus - pode estar restringindo o desenvolvimento de visões mais abrangentes das dinâmicas, oportunidades, e consequências possíveis da mudança global em direção ao Leste e Sul. (KEUKELEIRE ET AL., 2017, p. 438). Assim, Jorgensen (2015, p.24) identifica três grandes limitações na literatura sobre a política externa da UE: a escassez de estudos informados por teoria, rigorosos metodologicamente (admitidamente menos no caso da PEC); a representação excessiva de teorização liberal focada no subsistema da UE, e a falta de conhecimento sobre como o sistema internacional molda a política externa da UE.

Em termos mais específicos, a UE conduz sua política externa por meio do bilateralismo, (inter)regionalismo, e multilateralismo simultaneamente. Conforme Renard (2016) enfatiza, isso traz pelo menos duas questões que tem sido amplamente negligenciadas até hoje: (1) as parcerias estratégicas indicam uma mudança de distanciamento da política externa tradicional da UE, baseada no regionalismo e multilateralismo, em direção a uma abordagem bilateral mais profunda? E por que? (2) Esse novo bilateralismo é compatível com o regionalismo e multilateralismo? E como?

A tese do Realismo Comercial (Meissner, 2016) não encontrou uma preferência clara das instituições e dos atores da UE por uma abordagem inter-regional ou bilateral. Assim, DG Comércio foi claramente pragmático ao expressar sua preocupação que a escolha de arena de negociação respondesse a características da região homóloga. Já as representações diplomáticas da UE e funcionários vinculados ao SEAE expressaram diferentes agendas, atividades e prioridades em relação ao inter-regionalismo. Essa complexidade de agendas no interior do bloco é um "ponto cego" do Realismo Comercial e demanda pesquisa adicional.

As negociações multilaterais, também, se desenvolvem de uma maneira muito diferente e sem pré-negociações comparáveis com aquelas encontradas em ABCs (acordos bilaterais de comércio). No entanto, é impressionante que as interações da Comissão com estados terceiros antes de o Conselho emitir suas diretivas de negociação, sejam completamente negligenciadas 
(Woolcock, 2015, p. 394). E, da mesma forma, há a necessidade de mais estudos que identifiquem sistematicamente diferenças e similaridades de negociações bilaterais e multilaterais (de comércio) da perspectiva de elaboração de política da UE. (GASTINGER, 2016, p. 1381). À medida que comércio e globalização tornaram-se "palavras sujas" nas eleições de 2016 e 2017 nos EUA e na Europa, mais pesquisa sobre a questão de como e quando o bilateralismo é compatível com multilateralismo, como o primeiro pode promover o segundo, e a inter-relação entre eles deveria receber mais atenção na área de RI. (GARCIA-DURAN \& ELIAFSSON, 2017, p.19)

No entanto, ainda não foi realizado um levantamento extensivo das negociações comerciais da UE nos níveis bilateral, multilateral e regional - levando em consideração diferentes níveis de barganha e coesão interna do bloco (CONCEIÇÃO-HELDT, 2014; MEISSNER, 2016). Uma lacuna na literatura existe, também, no que concerne a projeção da PEC na arena internacional e para os países em desenvolvimento, e no inter-regionalismo como uma forma de negociação comercial. De fato, o inter-regionalismo é particularmente subinvestigado (SODERBAUM ET. AL., 2005), em comparação com outras formas como o multilateralismo. (MEISSNER, 2016, P. 39).

Mais especificamente, ainda de acordo com Meissner (2017), “apesar do aumento rápido na literatura sobre caracterização e teorização do inter-regionalismo, ainda há uma lacuna na pesquisa acadêmica sobre escolhas institucionais e os motivos que levam as essas escolhas”. Ruland $(2010,1280)$, em sua agenda de pesquisa, aponta para o fato de que ainda é terreno inexplorado sob quais condições as organizações regionais mudam de diálogo interregional para outros fóruns tais como parcerias estratégicas entre países individuais. Assim, o inter-regionalismo no contexto de negociações de comércio constitui um caso excelente para analisar essa escolha institucional a partir de uma perspectiva da UE. (MEISSNER, 2017) 
Embora a UE tenha indubitavelmente fornecido apoio para processos de integração regional em outras áreas, é evidente que o objetivo chave europeu é a assinatura de AAs englobando provisões $\mathrm{OMC}+$ significativas. Onde isso mostra-se difícil de alcançar, a UE não tem hesitado em mudar para uma abordagem bilateral e colocar em risco o potencial para integração mais profunda entre os estados membros de regiões particulares. Nesse sentido, torna-se pertinente o desenvolvimento de uma agenda de pesquisa voltada para o exame do impacto de acordos bilaterais sobre a cooperação inter-regional e multilateral, bem como de APCs inter-regionais sobre essa última esfera de cooperação (MCCROSSAN, 2014, p. 241). Principalmente porque a maior parte da literatura foca-se no inter-regionalismo puro ao invés de bilateralismo assimétrico, e na construção de identidade ou institucional como funções centrais inscritas na agenda inter-regional da UE, levando a uma falta de conhecimento sobre como interesses estratégicos desenvolvem-se no inter-regionalismo da UE (MEISSNER, 2017, p. 14).

A tese do Realismo Comercial encontrou externalidades negativas derivadas da competição da UE com atores rivais (tais como China, Japão e os EUA). No entanto, externalidades positivas também resultaram das negociações de linhas de tarifa, por exemplo. Conforme Meissner (2016) enfatiza, isso requer pesquisa adicional. Além disso, a maioria dos pesquisadores que examina a política externa comercial europeia tem se focado nos Estados Membros da UE e grupos de interesse como fatores explanatórios internos à UE (POLETTI \& DE BIÈVRE, 2013). Isso levou a uma falta de conhecimento de como fatores externos à UE (enraizados no sistema internacional) influenciam decisões de comércio (idem).

De fato, Orbie et al. (2015, p. 7), em sua agenda de pesquisa, também enfatizam que embora os desafios internacionais sempre tenham feito parte do quebra-cabeça, os trabalhos sobre a União Europeia têm se centrado principalmente em fatores internos ao bloco, por exemplo o impacto da "voz única" sobre a efetividade internacional do bloco. Assim, ainda são 
poucos os pesquisadores que desenvolvem pesquisa sobre o impacto do contexto internacional - oportunidades e obstáculos - sobre a ação externa da UE. Kissack enfatiza bem esse ponto: “pouca, ou nenhuma, atenção sistemática tem sido dedicada à questão de como o caráter do sistema multilateral influencia, constrange, ou capacita a UE a agir" (KISSACK 2010, P. 109; JØRGENSEN AND WESSEL, 2011; JØRGENSEN AND LAATIKAINEN 2013; LAATIKAINEN 2013, p. 413) De uma forma mais específica, há necessidade de uma investigação mais profunda sobre o impacto recíproco da UE e organizações internacionais.

E também ainda são raras as análises de política externa comercial europeia sob uma perspectiva realista, porque a área de Estudos Europeus tem privilegiado abordagens idealistas ou construtivistas no estudo da política externa da UE. No entanto, mais recentemente, trabalhos utilizando Realismo Clássico, Estrutural, ou Neoclássico têm ganhado tem ganhado maior projeção na disciplina. Em especial, essas análises buscam explicar a capacidade internacional crescente do bloco, suas ações internacionais em curso, bem como a trajetória futura da UE em um mundo multipolar (SMITH, 2016).

O caso específico das negociações UE-GCC (Conselho de países do golfo), em que a UE manteve um desenho inter-regional de negociação - mesmo levando em consideração a baixa coesão dos países do golfo - contraria a expectativa do Realismo Comercial. Literatura secundária e os trabalhos de Antckwiecz \& Momani e Meissner apontam que preocupações relacionadas a normas internacionais e objetivos políticos poderiam ter motivado essa decisão dos países europeus. No entanto, pesquisa adicional sobre o caso seria extremamente benéfico para a comunidade de relações internacionais ${ }^{11}$.

\footnotetext{
${ }^{11}$ Com tantas negociações de comércio "profundas e abrangentes" acontecendo simultaneamente, também se coloca a pergunta: a DG Comércio ainda tem a capacidade de fazer frente à agenda de comércio? A preocupação anterior do diretor da DG Comércio para Acesso a Mercados, Matthew Baldwin, com relação à capacidade dos Estados Membros de "promover seus interesses [...], questionar a Comissão, e defender a linha contra a ‘incursão’ de países terceiros (BALDWIN, 2006, P. 930) foi externada antes de a estratégia 'Global Europe' ser lançada. Portanto, há a necessidade de mais
} 
Em resumo, a nova ordem mundial em formação tem atraído interesse de pesquisa considerável sobre multipolaridade e política externa europeia, conforme explorado por Renard e Biscop (2012), Kierkegaard et al. (2012) and Makarychev (2014) (Manners, 2014, p.887). Keukeleire (2017, p.438), por outro lado, enfatiza a necessidade de descentralizar a análise das relações internacionais da UE e também de olhar para as relações UE-potências emergentes a partir de uma perspectiva não-Europeia (FISHER ONAR \& NICOLAÏDIS 2013; KEULEERS, FONCK, \& KEUKELEIRE 2016). Assim, tendo em vista a contínua evolução da UE, o desafio para a pesquisa acadêmica sobre o bloco consiste em repensar os modelos e abordagens utilizados para analisá-la (SHKRELI, 2015).

\section{Abordagens da UE: esferas inter-regional e bilateral}

Os pesquisadores da área já desenvolveram diferentes explicações para o interregionalismo e suas funções, que, de acordo com Meissner (2017), podem ser grossamente alocadas a três categorias: primeiramente, uma função voltada para o exterior direcionada ao nível global. Por meio das funções de agenda-setting e racionalização (DOIDGE, 2008; RULAND, 2010), a UE promove uma ordem mundial liberal-institucionalista por meio do uso do inter-regionalismo (SODERBAUM ET AL., 2005, p.366). De acordo com essa visão, os diálogos inter-regionais servem como casas de compensação (DOIDGE, 2008, p.233) para desenvolver posições comuns em assuntos específicos para negociações multilaterais na OMC.

A segunda categoria concerne à identidade da UE como um poder normativo e ator global que apoia a integração regional. Essa explicação sobrepõe-se com as funções de formação de identidade coletiva e construção de instituição delegada ao inter-regionalismo, e

pesquisa sobre como a Comissão lida com essa carga de trabalho crescente. (ADRIANSEN, 2014, p. 182) 
aproxima-se do entendimento do inter-regionalismo como um princípio de política externa em seus próprios termos. E, por fim, um terceiro tipo de explicação, ainda sub-investigado teórica e empiricamente, é mais estratégica em substância, e explora a ambição da UE de aumentar seu poder e competitividade por meio do inter-regionalismo (RULAND, 2010, p. 1275; SODERBAUM ET AL. 2005, p. 366). Nessa explicação, o inter-regionalismo serviria a função de soft balancing (DOIDGE, 2008). Esse comportamento de equilíbrio, por meio de instituições inter-regionais, visa a melhorar o poder relativo da UE vis-à-vis atores rivais tais como os EUA ou a China (SODERBAUM ET AL. 2005, p. 374).

De acordo com Renard (2016, p. 19), o bilateralismo pode ser definido como uma relação diádica. Esse relacionamento pode ser assimétrico devido a um equilíbrio de poder imperfeito, ou, alternativamente, a uma diferença na natureza dos atores. Esse último elemento definidor é adaptado para encaixar-se na análise da UE como ator unitário. Tradicionalmente, o bilateralismo tem sido limitado a relações entre estados-nação, porém mais recentemente o termo tem sido aplicado na ação externa da UE também.

As estratégias de APCs da UE têm sido mediadas ao longo do tempo pelas preferencias ideacionais da liderança do DG Comércio, objetivos normativos, e interesses econômicos realistas inseridos nos desenvolvimentos internacionais em evolução. Tendo em vista que todos APCs beneficiam a UE de alguma forma, mesmo se os resultados econômicos agregados são insignificantes, a estratégia de APCs poderia ser classificada como tendo sido sempre uma busca realista de determinados interesses econômicos europeus. O documento "Global Europe" potencializou isso e abandonou alguns aspectos de política comercial no que se refere a governança global, a liderança da UE em moldar essa governança, bem como as relações internacionais. (GARCIA, 2013, p. 535).

Carbone \& Orbie (2014, p.3) enfatizam que a UE se distanciou de seu discurso prévio de "fortalecer a globalização" (MEUNIER, 2007) e trouxe os interesses econômicos ao centro 
de sua agenda comercial externa (HERON \& SILES-BRUGGE, 2012). Portanto, face ao impasse das negociações na $\mathrm{OMC}$ e às pressões por liberalização competitiva dos EUA e países asiáticos, colocou mais ênfase em comercializar com potências emergentes ao invés de países em desenvolvimento (COMISSÃO EUROPÉIA, 2006). Interessantemente, a crise financeira e econômica não interrompeu essa tendência, mas pelo contrário, reforçou ainda mais a necessidade percebida de forjar o livre-comércio (DE VILLE \& ORBIE, 2014).

Somente após a publicação do relatório Global Europe: competing in the world em Julho de 2006, e de uma interrupção na Rodada Doha, é que a União Europeia mudou sua estratégia para negociar no nível bilateral ou regional (SBRAGIA, 2010), porque em Cancún privilegiava o nível multilateral ${ }^{12}$. Assim, em um excerto notável, o documento Global Europe afirma abertamente que os arranjos comerciais prévios eram muito frequentemente baseados nas preocupações políticas da UE e que almeja voltar para seu negócio central de defender interesses econômicos (BOSSUYT ET AL. 2018, p. 8):

"Enquanto nossos acordos atuais apoiam nossos objetivos de desenvolvimento e vizinhança bem, nossos principais interesses comerciais, incluindo na Ásia, são menos bem servidos. [...] Nós deveríamos continuar a incorporar outras questões e o papel maior da política comercial nos desenvolvimentos comerciais bilaterais. Mas a fim de que a política comercial ajude a criar empregos e impulsionar o crescimento, os fatores econômicos devem desempenhar um papel primário na escolha de APCs futuros (COMISSÃO EUROPÉIA, 2006, p. 9) "

Após avaliar a estratégia Global Europe (2006-2010), a Comissão propôs, com Trade, Growth \& World Affairs, uma nova agenda de política comercial para os próximos cinco anos (2010-2015). Essa estratégia foi parte da nova estratégia de crescimento Europe 2020 em que

\footnotetext{
${ }^{12}$ Apesar da política de defender a política de 'multilateralismo primeiro' (Lamy, 2002) nos anos 1990, a UE não conseguiu progresso nas assim chamadas 'questões de Cingapura" (compras governamentais, política de competição, e proteção para investimento) (GRUMILLER, 2016, p. 6). Nos casos das relações com a ASEAN e MERCOSUL, enfatiza-se que houve uma mudança, além de escopo - de interregionalismo para bilateralismo - de um desenho abrangente para um mais seletivo. (MEISSNER, 2016, p. 53)
} 
o comércio é considerado como um fator-chave para impulsionar o crescimento ${ }^{13}$ (BREUSS, 2015, p. 238).No documento Trade for $A l l^{14}$, publicado em 2015, a Comissão Europeia compromete-se pela primeira vez com uma abordagem aberta em relação a acordos bilaterais e regionais a fim de "desenvolver contribuições para lidar com desafios chave enfrentados pela OMC, baseado em soluções encontradas em iniciativas bilaterais e regionais" (p.30). Essa abordagem aberta engloba a prontidão de alargar seus APCs a países-terceiros que desejem integrá-los (incluindo o TTIP).

É importante enfatizar que o bilateralismo coexiste com o inter-regionalismo e o multilateralismo, embora aparentemente o sistema esteja se reordenando em favor da primeira dessas tendências. Portanto, a UE parece estar respondendo a estímulos externos em seu movimento recente de reequilíbrio em direção ao bilateralismo. No entanto, Renard (2016) avança a proposição de que tanto fatores externos quanto internos ao bloco europeu seriam responsáveis pela adaptação recente, isto é, por uma ênfase maior à esfera bilateral.

Garcia-Duran \& Eliafsson (2017, p.18) apresentam uma explicação centrada mais no ambiente externo à UE, e em certa medida complementar à perspectiva do Realismo Comercial, no que se refere ao uso crescente de FTAs bilaterais pela UE ${ }^{15}$. De 2006 a 2009, a UE buscou parceiros bilaterais entre atores importantes no comércio (Índia, ASEAN, e Coréia do Sul), ao passo que desde então a UE tem-se focado em alcançar acordos com os membros antigos do

\footnotetext{
${ }^{13}$ Young (2014) chama atenção para os limites do mercado da UE como uma fonte de influência: embora ele seja indubitavelmente um recurso de poder crítico, existem limites para sua fungibilidade. Isso sugere a necessidade de um distanciamento da ênfase prevalecente nas capacidades de poder da UE, para uma compreensão mais relacional de poder

${ }^{14} \mathrm{~A}$ agenda estabelecida pelo documento visa promover o comércio em serviços, facilitar o comércio digital, apoiar a mobilidade, resolver questões regulatórias como uma prioridade, facilitar a gestão eficiente de aduanas, assegurar o acesso a energia e matérias-primas, e proteger a inovação. (Comissão Européia, 2015). Ademais, a publicação elaborada em 2015 pela Comissão Européia atribui aos países emergentes a falta de progresso no âmbito multilateral.
} 
Quad (Canada, Japão, e os EUA), que são parceiros comerciais ainda mais importantes ${ }^{16}$. Assim, essa mudança indicaria que os acordos bilaterais da UE iniciados no século XXI podem ser justificados da perspectiva do sistema multilateral da OMC até 2008. No entanto, os acordos bilaterais ou negociações desde então poderiam ser vistos como substitutos para uma estratégia multilateral ${ }^{17}$ (ou no caso do TTIP, contra-multilateralista).

Portanto, a crise de 2008 teve um impacto distinto das expectativas iniciais, que apontavam para um maior protecionismo da UE, e mesmo um overhaul da política comercial do bloco. Bollen et al. (2016) também enfatizam essa tendência da UE de buscar novos acordos com grandes parceiros (Canadá, Japão e USA), reforçando o viés liberal da política comercial da UE - porém também sublinham que, no que se refere a persecução de mecanismos de defesa comercial, houve uma reversão da postura europeia. Em síntese, o efeito da crise sobre o domínio do comércio na UE foi assimétrico, com uma revitalização da liberalização no âmbito bilateral, mas com uma reversão da tendência a apoiar mecanismos de defesa comercial (para contrabalançar os efeitos negativos da liberalização), e garantir maior alavancagem vis-à-vis países em desenvolvimento.

\footnotetext{
${ }^{16}$ Além de concluir acordos comerciais com novos parceiros, a UE está também renovando as relações de comércio existentes com parceiros de longa data na África, no Caribe e no Pacífico (ACP), ao negociar acordos de comércio com seis grupos de países do ACP. Esses APEs são o sucessor do regime de Lomé, que era considerado uma relíquia de tempos coloniais e inconsistente com as regras da OMC. Em 2002, a UE e o grupo da África Oriental e do Sul, que inclui o Zimbabwe, iniciaram negociações para um APE. (BOSSUYT ET AL, 2018, p. 9)

${ }^{17} \mathrm{O}$ multilateralismo pode ser definido como a relação coordenada entre três ou mais partes de acordo com um conjunto de regras ou princípios (Keohane, 1990). Essa definição implica que há uma miríade de expressões diferentes do multilateralismo. O número de partes pode variar de três ou poucas (minilateralismo) a todos os estados-nação existentes (multilateralismo universal). Essas interações multilaterais podem ser reguladas por legislação formal (hard law), ou arranjos de soft law. (RENARD, 2015, p. 20)
} 


\subsection{Estratégias em relação a países emergentes (BRICS, América Latina, África e Sudeste Asiático)}

À medida que as negociações no âmbito da OMC entram sua segunda década, está tornando-se evidente que um acordo abrangente pode ser impossível de se alcançar. No entanto, embora as negociações multilaterais pareçam estagnadas, a liberalização e a criação de regras para o comércio internacional seguem adiante no número crescente de acordos preferenciais de comércio (APCs). Os APCs são por definição acordos que eliminam tarefas entre membros apenas. (KIM \& MANGER, 2016, p.1)

Os "novos" APCs da UE tem sido explicitamente "motivados por competição" e voltados a novos alvos econômicos na América do Norte, e no Sul e Leste Asiático (Comissão Europeia, 2010). Esses acordos estão em grande medida alinhados com a Agenda de Lisboa sobre competitividade $^{18}$ e sua agenda de regulação melhor (Better Regulation). A UE evidentemente não tem sido a única potência econômica a perseguir novos FTAs - os EUA alegadamente iniciaram essa tendência - mas, como uma potência regional tendo que conciliar uma variedade de interesses nacionais, a estratégia europeia tem sido menos global em cobertura geográfica, e menos funcionalista em sua abordagem operacional do que a estratégia dos EUA (HORN ET AL., 2009, 28). (LAURSEN \& ROEDERER-RYNNING, 2017, p. 764)

De acordo com Woolcock (2014, p.46), os APCs estão moldando a política comercial e de investimento mais do que negociações multilaterais ou políticas comerciais autônomas. A política da UE para APCs permite diferenciação. Há uma distinção entre a política da UE visà-vis os mercados emergentes (baseada mais em reciprocidade) e os LDCs (baseada mais em desenvolvimento) ${ }^{19}$. Além disso, um trabalho recente do mesmo autor sugere que também há

19 Burckhardt (2013, p. 284) argumenta que a política comercial da UE não está a serviço do desenvolvimento, como a Comissão afirma (OMC, 2009, p.8), mas que os interesses mercantilistas da UE tomaram precedência" (ACP conselho de ministros, 2007). Na área do comércio, a UE se parece 
diferenciação entre LDCs e países em desenvolvimento de renda-média. Essa diferenciação aplica-se ao longo de todas as arenas de política, acesso a mercado e regras.

Conforme salientado por Sahakyan (2016, p. 80), na América Latina, Sul e Sudeste asiáticos, a política comercial da UE tem sido dominada por tentativas de ganhar novos mercados para empresas europeias e nivelar seu campo de jogo com competidores. Em outras regiões, por outro lado, tal como na vizinhança da UE e nos países menos desenvolvidos da África, Caribe e Pacífico, a política comercial da UE tem sido principalmente determinada por considerações políticas, tais como ajudar os países a se preparar para uma possível acessão à UE, garantir estabilidade política nos arredores da UE, e fornecer concessões unilaterais para propósitos de desenvolvimento (AHEARN, 2011; PANAGARIYA 2002).

Ademais, Sahakyan (2016, p.89) identifica duas estratégias do bloco europeu. Nas regiões e países onde a UE sentiu que suas posições estavam ameaçadas como um resultado de APCs de países-terceiros, ela adotou respostas "defensivas" na forma de assinatura de contraacordos e estabelecimento de nivelamento do campo de jogo para suas multinacionais vis-à-vis seus competidores. Em outras regiões e países, por outro lado, a UE antecipou possíveis efeitos discriminatórios e iniciou ou assinou PTAs "pró-ativos" para garantir uma vantagem de iniciador e evitar a materialização de possíveis efeitos adversos de futuros APCs de partes terceiras.

Assim, a UE está conduzindo negociações sobre acordos de comércio e parceria econômica - eufemisticamente chamados de acordos de livre comércio - com os BRICS, que têm fraco poder de barganha (SRINIVASAN, 2014). Tais acordos constituem tentativas do

mais com uma "grande potência do que a um poder civil, com um espectro amplo de instrumentos que emprega coercitivamente, seguindo um processo de tomada de decisão centralizado. Assim, durante as negociações do EPA, a UE demonstrou continuamente sua orientação de grande potência ao longo de um intervalo de 10 anos. Como não havia grandes interesses econômicos em jogo, uma explicação possível, de acordo com Burckhardt, poderia ser que a DG Comércio simplesmente "não pode fazer desenvolvimento" 
parceiro negociador mais forte de extrair concessões relacionadas a propriedade intelectual e padrões trabalhistas que vão além do TRIPS, da convenção da OIT e outros acordos multilaterais (SRINIVASAN, 2014, p.33). Nesse sentido, Meissner (2016) enfatiza que as negociações da EU com atores rivais (e países em desenvolvimento) exibem em alguns casos uma configuração de jogo de soma-zero (por exemplo em questões relativas à propriedade intelectual) e em outros casos obedece a uma configuração de soma-positiva (por exemplo no que diz respeito à eliminação de tarifas) - um fato que merece maior atenção da comunidade acadêmica de relações internacionais.

\subsection{Preferências das instituições da UE}

Separar os níveis de análise (institucional, internacional e doméstico) ajuda a aumentar a clareza analítica ao explorar as origens da PEC da UE ${ }^{20}$ (VAN LOON, 2018, p.6). O nível institucional ecoa aquilo em que a maioria dos estudos se foca ao abordar a UE como um ator comercial excepcional e ao adotar os avanços convencionais à PEC da UE. Assim, as explicações internacionais, ou também sistêmicas, veem a política comercial como uma reação às oportunidades e desafios advindos do sistema internacional. Na abordagem sobre o nível doméstico, a explicação para a política comercial está enraizada na política doméstica, onde os tomadores de decisão são (não) responsivos às demandas de atores como grupos de interesse e o eleitorado. (VAN LOON, 2018, p. 6).

No campo do comércio, o quadro institucional da UE comporta-se de forma similar a um estado tradicional (YOUNG, 2006, P. 203). O poder é centralizado dentro da DG

\footnotetext{
${ }^{20}$ Igualmente, tratar atores rivais, região homóloga, ou blocos de países como caixas-pretas permite distinguir entre fatores extra-UE, e intra-UE, no processo de formulação de política comercial da UE (MEISSNER, 2016)
} 
Comércio $^{21}$, que foi bem-sucedida em capturar a política externa comercial (BILAL, 1998). O vasto volume da literatura confirma a relativa independência da Comissão nas negociações de comércio, seja de uma perspectiva do agente-principal, ou por meio de modelos de jogos de dois/três níveis. As perspectivas do agente-principal falam de agency slack, e do poder da Comissão de formar agenda (MEUNIER, 2007, p. 908), bem como abordagens multi-nivel situam a autonomia do negociador dentro do win-set da UE (VAN DEN HOVEN, 2007) (BURCKHARDT, 2013, p. 282)

De acordo com os artigos 207 e 208 do TFEU, é o Conselho que autoriza as negociações a começar, fornecendo um mandato aos negociadores. Os negociadores então conduzem essas negociações em consulta com um comitê especial, isto é, o TPC (Comitê de Política Comercial), que deverá "assistir" os negociadores. No fim, o Conselho autoriza a assinatura do acordo internacional e ratifica-o A dinâmica das negociações dentro do Conselho são frequentemente analisadas ao longo desses três estágios do mandato, as discussões no TPC, e a ratificação, focando-se no equilíbrio entre a autonomia negociadora da Comissão e o controle dos Estados Membros (DELREUX 2008; DUR \& ELSIG 2011) (LARSÉN, 2017)

Por causa de sua estrutura interna complexa, a UE é frequentemente vista como um negociador rígido, que apresenta a seus opositores na negociação uma posição de "pegar ou largar” (BRETHERTON \& VOGLER, 2006, P. 79). Os cientistas políticos que tem pesquisado a elaboração de política externa da UE chegaram à conclusão de que essa postura pode ser explicada usando análise de agente-principal. Meunier (2000), Nicolaidis (1999), Pollack

\footnotetext{
${ }^{21}$ Uma unidade dedicada ao acesso a mercados foi criada dentro da DG comércio, que administra uma base de dados grande listando barreiras estrangeiras por setor, país e tipo de medida. Adicionalmente, a Comissão montou times de acesso a mercado em 39 países terceiros, para monitorar a implementação de acordos de livre comércio (Comissão Européia, 2010, p. 12). A estratégia é identificar barreiras estrangeiras às importações da UE, de uma forma abrangente, priorizá-las, e pressionar governos estrangeiros a eliminá-las. (Shaffer 2006, p. 838; Bretherton and Vogler 2006, p. 231). (BURCKHARDT, 2013, p. 272). Além disso, enfatiza-se que em Novembro de 2017 a Comissão publicou seu primeiro relatório sobre a implementação de APCs.
} 
(2003), e Woolcock (2005) todos demonstraram como as preferências dos Estados Membros da UE (os principais) tem sido combinadas em uma posição conjunta da UE, ou uma "voz única" representada pela Comissão (o agente), por meio de processos complexos e frequentemente demorados ${ }^{22}$. Isto é, o poder de representar a UE e concluir acordos comerciais com partes terceiras foi delegado à Comissão. (LARSÉN, 2007).

No entanto, os atores societais podem ser decisivos em moldar as preferências europeias de comércio, ao fazer lobby seja junto aos Estados-Membros, seja junto à Comissão Europeia. (DUR, 2007; YOUNG, 2007). É indiscutível que tanto os interesses econômicos, tais como aqueles de exportadores, importadores, e de competição com importações, e organizações nãogovernamentais advogando consideração de preocupações desenvolvimentistas, ambientais, ou outras na formulação de políticas comerciais, tentam influenciar as políticas comerciais Europeias (DUR E DE BIÈVRE, 2007; GERLACH, 2006). Porém, pouquíssimos trabalhos têm tratado dessa temática, e não existe um consenso entre aqueles já realizados, sobre a predominância de atores societais ou dos Estados-Membros e da Comissão ${ }^{23}$ (DUR \& ZIMMERMAN, 2007, p. 777)

${ }^{22}$ Assim, lidar com a UE pode ser excruciante. De um lado, a política consensual da UE pode em última instância levar ao impasse se um acordo entre seus estados membros não pode ser alcançado. Por outro lado, a UE pode sair fortalecida por causa da política consensual. O escrutínio pelos representantes dos estados membros e suas constituencias domésticas pode reduzir a autonomia do negociador, mas fortalecer o poder de barganha dela, levando ao famoso "paradoxo da fraqueza" de Schelling (Meunier 2005; Dür 2007). (DE BIEVRE ET AL. 2018, p. 2).

${ }^{23} \mathrm{~A}$ Comissão tem o poder de moldar a rede de política (policy network) em que se baseia para garantir um input constante de informação de qualidade. Assim, a Comissão pode atuar como um metagovernante que molda e gerencia a rede de política, ao invés de atuar como um agregador passivo dos interesses da multitude de stakeholders afetados pelas decisões de política comercial (BELL \& HINDMOOR 2009; SØRENSEN \& TORFING 2009). Aqui, a Parceria de Acesso a Mercado, as reuniões técnicas informais e as várias consultas organizadas pela Comissão são assuntos que demandam pesquisa adicional da comunidade de relações internacionais (ADRIANSEN, 2014, p. 183) 
Tabela 1: Preferências por interesse materiais vs. valores das instituições da UE

\begin{tabular}{|c|c|}
\hline Ator & Preferência \\
\hline Comissão (DG Comércio) & Interesses materiais \\
\hline Conselho & Interesses materiais \\
\hline Parlamento Europeu & Valores \\
\hline SEAE & Valores (tendência mista) \\
\hline
\end{tabular}

Fonte: McKenzie \& Meissner (2016)

Em síntese, conforme Meissner (2016, p. 80) enfatiza,

"Se as relações comerciais são jogos não competitivos entre entidades semelhantes a estados, fatores internacionais não podem ser variáveis explanatórias para a PEC. Ao contrário, a PEC em um mundo liberal depende de fatores domésticos. Esses fatores vão desde ideias (Kahler, 1985), a instituições (Meunier, 2000; 2005; 2007), a grupos de interesse (Young 2000, Dur 2007). Três grandes linhagens de teorização liberal representam essas três explicações diferentes. As ideias podem relacionar-se a uma noção construtivista de liberalismo que enfatiza a UE como um ator normativo que exporta seu modelo de integração e pressiona por liberalização e livre comércio. Disputas institucionais referem-se a um raciocínio institucional do liberalismo, que deriva da distribuição de competências e poder dentre órgãos supranacionais, e entre instituições supranacionais e os EMs da UE. O terceiro tipo de liberalismo, pressões de grupos de interesse, foca-se em pressões domésticas para a formulação de política, e explica-a por meio da investigação de atores de negócio e societais"

Além desses fatores sublinhados por Meissner (2016), enfatiza-se que, após a entrada em vigor do tratado de Lisboa, a competência exclusiva da Comissão no campo de formulação de política comercial foi mantida, porém a assinatura do Tratado gerou expectativa sobre maior coordenação entre os bastiões institucionais da DG Comércio e o SEAE, o serviço de ação externa da EU. Pouquíssimos trabalhos têm analisado essa dimensão da coerência horizontal da política externa europeia, à exceção dos estudos iniciais de Schade (2016), Bossuyt et al. (2018). 


\section{CAPÍTULO 2}

\section{Realismo Comercial e potências emergentes}

\subsection{Introdução}

Os quadros analíticos mais comumente aplicados para o estudo da PEC da UE usam as explicações institucionalistas já mencionados; o Agente-Principal e a abordagem dos jogos de dois/três níveis. Na tradicional metáfora de Putnam, o jogo de dois níveis (1988) ${ }^{24}$ lida com uma delegação dupla de competências: dos estados membros ao Conselho (MORAVCSCIK, 1998) e no nível da UE, do Conselho à Comissão (YOUNG 2013, P. 128). Outros estudos enfatizam a PEC da UE como um jogo de três níveis ao incluir o nível internacional, isto é, o parceiro de negociação da UE (PATTERSON 1997; FRENNHOFF LARSÉN 2007). O foco nos jogos de dois/três níveis geralmente centra-se no quadro institucional, moldando a agregação das posições dos Estados-membros em uma posição única da UE. O modelo AgentePrincipal (Pollack 2006) estuda essa delegação da autoridade de política comercial do principal (Conselho) ao agente (Comissão) e preferências de política comercial divergentes, resultando em uma relação inter-institucional de "cooperação vs. conflito" (DA CONCEIÇÃO, 2010, P. 1109)

Apesar da base cultural europeia do realismo (particularmente de seus autores clássicos de meados do século), é a "versão" realista estrutural que tem sido a mais aplicada à UE (HYDE-PRICE 2007; JONES 2007; ROSATO 2010). Os autores neorrealistas (tanto nas

\footnotetext{
${ }^{24} \mathrm{O}$ conceito dos jogos de dois níveis foi referenciado na obra de Robert Putnam e trata de chamar a atenção para o fato das negociações internacionais sempre envolverem atores de diferentes naturezas (Estado e atores sociais) e se darem em pelo menos dois níveis: o internacional e o âmbito doméstico (PUTNAM, 1988).Outros trabalhos avançaram nesta discussão, destacando a negociação no nível doméstico, particularmente com a influência do Legislativo (ver: Martin, Lisa. Democratic Commitments. Legislature and International Cooperation. Princeton: Princeton University Press, 2000).
} 
formas defensivas, como ofensivas) geralmente entendem a segurança europeia como substanciada em um equilíbrio interno de poder. Para essa literatura realista, a UE serve a três propósitos diferentes para seus Estados Membros: ela promove seus interesses econômicos na economia global; ela ajuda-os a moldar o meio regional; e "serve como o repositório institucional das preocupações normativas de segunda ordem dos estados membros da UE" (HYDE-PRICE, 2008, p. 31). Nesse sentido, a UE seria um mero arranjo institucional com influência limitada em questões centrais de segurança, e sua política externa "pouco mais que a soma de suas partes" (BICKERTON, 2011, p. 172)

A UE, semelhantemente aos estados, existe no sistema internacional que restringe e guia (em algum nível) a ambição e escopo de suas decisões de política externa. Assim, Jones (2007) argumenta que:

\begin{abstract}
“O desenvolvimento e decisões de política externa da UE, apesar das asserções dominantes dos construtivistas e liberais de que outros fatores, "normativos" ou "cooperativos" são proeminentes, podem ser rastreados até mudanças nos sistemas internacionais e regionais. A emergência da bipolaridade após o fim da Segunda Guerra Mundial impulsionou a integração europeia como uma salvaguarda contra a ameaça da União Soviética (entre outros), e a transição para a unipolaridade após a desintegração da União Soviética precipitaram a evolução da UE de um ator puramente econômico para um mais capaz internacionalmente".
\end{abstract}

A partir da análise desenvolvida nos capítulos anteriores, é possível afirmar que a UE tem buscado se retratar como uma força positiva para as relações internacionais, promovendo processos de integração regional, os direitos humanos e padrões sociais - de acordo com o quadro do "poder normativo" (MANNERS, 2002) - mas que, na prática, tem-se comportado seguindo uma estratégia realista (AGGARWAL \& FOGGARTY, 2004; NITOIU \& SUS, 2017). Em especial na esfera de relações comerciais, essa organização tem demonstrado características de uma potência mercantilista - buscando contrabalançar o poder de atores rivais 
- e colocando a preocupação com o desenvolvimento internacional em segundo plano (Burckhardt, 2013 CARBONE \& ORBIE, 2014)

O Realismo Comercial argumenta que a variação da PEC da UE é um resultado de sua tentativa de assegurar poder econômico e regulatório vis-à-vis atores em regiões terceiras e o grau variável de coesão dessas regiões, ou espírito de equipe. Ele espera que fatores extraregionais expliquem a PEC: o resultado concreto de interregionalismo abrangente onde os atores rivais têm relações comerciais amplas $e$ a região homóloga é coesa (MEISSNER, 2016).

Uma explicação alternativa para isso, enfatiza Meissner (2016), seriam a pressão de grupos de interesse e a heterogeneidade de preferências dos Estados-Membros derivando, respectivamente, do liberalismo comercial e do quadro do agente-principal. Em contraste com o Realismo Comercial, uma combinação desses fatores esperaria o bilateralismo abrangente onde os esforços de lobby dos atores orientados para exportação são altos e os EstadosMembros da UE tem preferências heterogêneas.

\subsection{Origens e evolução do quadro teórico}

O realismo é produto de uma longa tradição histórica e filosófica, ainda que sua aplicação direta a assuntos internacionais seja de uma safra mais recente. Essa corrente teórica é baseada em uma visão do indivíduo como primordialmente egoísta e motivado pela busca de poder. ${ }^{25}$ Em um mundo realista, os Estados confiam primordialmente em equilibrar o poder de outros Estados e na contenção para manter o sistema internacional intacto e o menos ameaçador

\footnotetext{
${ }^{25}$ Para os realistas, valores normativos e regimes internacionais não tem poder em si mesmos. A proclamação dos direitos humanos carece de valor analítico ou explanatório no que se refere à ação estatal. Um regime internacional importa apenas na medida em que reflete a "distribuição de poder no mundo" pré-existente (Mearsheimer, 1994; 1995, p.7), e as normas tornam-se subsumidas na "estrutura material do sistema internacional" (Mearsheimer, 1995, p.70) (CASLA, 2018, p. 144)
} 
possível (MINGST, 2009, p. 59). No entanto, conforme Mastanduno (2014, p. 25) enfatiza, "realismo significa coisas diferentes para diferentes pesquisadores; e um artigo recente identificou nada menos que treze versões dessa proeminente escola de pensamento (ONEA, 2012, p. 156)".

De certa forma, o realismo (incluindo suas versões mais contemporâneas com Waltz e Mearsheimer) pode ser considerado como uma das abordagens mais duradouras de RI. Uma das razões para isso é que "se configura como uma ciência prática do não-não senso da política internacional" (SUTCH \& ELIAS, 2007, p. 42). No realismo, todos eventos na política internacional fazem sentido e podem ser explicados por princípios relativamente claros e imediatos. Por essas razões, o realismo não apenas permanece como um pilar da teoria de Relações Internacionais (GOLD AND MCGLINCHEY, 2017, p. 46), mas também uma abordagem próspera nos campos amplos de estudos políticos e teoria política (BELL, 2017). O realismo clássico tem moldado a maneira pela qual as relações entre os estados ao longo dos séculos tem sido entendidas e ainda influencia formuladores de política hoje. (ORSI ET. AL, 2018, p. 1).

Conforme Guzzini (2017, p.10) enfatiza:

“"Realismo' é um termo que é usado em pelo menos dois domínios. Por um lado, refere-se à teoria observacional de relações internacionais que tem de encontrar explicações para coisas como o fim da Guerra Fria. Por outro lado, o realismo refere-se a uma doutrina ou estratégia particular de política externa/segurança, frequentemente associada com estratégias de contenção ou preparação militar para a guerra. No primeiro caso, é uma visão externa para analisar o mundo, frequentemente focada em explicar os comportamentos dos atores. No segundo, corresponde a desenvolver um plano geral de ação de um ator. Não é difícil ver como os dois podem ser confundidos. Embora generalizado, está errado no entanto. Nessa confusão, sempre que as coisas se tornam amargas, sempre que o mundo está passando por violência ou guerra, quando as pessoas usam estratégias realistas, então alegadamente a teoria realista explicando aquela ação é vindicada; e sempre que a diplomacia é bem-sucedida, a guerra é evitada e a cooperação alcançada, então 'liberalismo', 'idealismo', ou qualquer que seja o termo escolhido, está correto." 
Desde o fim da Guerra Fria, o realismo retornou às suas raízes. Os pesquisadores realistas mostram interesse renovado nos pensadores fundadores de seu paradigma, o entendimento trágico deles a respeito da vida e da política, sua preocupação prática em relação à ética, e sua compreensão da teoria como ponto inicial para narrativas explanatórias ou previsões prospectivas que são altamente dependentes do contexto. Apesar de suas diferentes perspectivas a respeito da política mundial, as obras de Tucídides, Nicolau Maquaviel, E. H. Carr, Reinhold Niebuhr, Arnold Wolfers, John Herz, Hans Morgenthau e Hannah Arendt demonstram uma unidade notável de pensamento, tendo em vista que elas foram impulsionadas por preocupações similares a respeito de "problemas perenes" (MORGENTHAU, 1962, p.19) (ROSCH \& LEBOW, 2018, p. 6)

Como a tradição intelectual principal em Relações Internacionais, seria certamente esperado que a UE fosse amplamente discutida dentro do realismo. No entanto, não apenas aqueles estudando a UE raramente consideram os insights teóricos do realismo (RYNNING, 2005, p.4), como os autores realistas não se engajam com os problemas e questões afetando a UE (MORGAN, 2005, p. 203; PETERS, 2010, p.8). Talvez seja porque o realismo traz certo desconforto com os 'valores liberais dominantes' associados à UE (HYDE-PRICE, 2007). Como resultado, ao invés de ser dominante, a literatura realista sobre a UE é colocada em uma posição secundária, raramente útil e frequentemente criticada por sua inadequação para o estudo de questões relacionadas à Europa: uma teoria Vestfaliana que não pertence ao caráter de ator pós-Vestfaliano da UE (COOPER, 2004; MORGAN 2005). (BARRINHA, 2016, p. 2)

Pertencendo à tradição da escola realista, e à linha de trabalhos derivada das obras de Carr (1939), Hirschmann (1969) e Gilpin (1981), o Realismo Comercial reformulou essa perspectiva teórica sobre relações econômicas externas ao desenvolver hipóteses testáveis e 
aplicando-as à PEC da União Europeia ${ }^{26}$. Assim, trata-se de um trabalho parcimonioso, coerente, acurado e específico no que se refere à coerência multicausal, e que assim forneceria “o rigor analítico necessário para ser uma alternativa à escola liberal” (MEISSNER, 2016, p. 306).

Levando em consideração a dominância do neo-realismo (Waltz, 1979), a abordagem do Realismo Comercial (Meissner, 2016) baseia-se em elementos centrais da teorização realista, e, portanto, não se identifica com um dos "realismos típicos": Neorrealismo (1979), Realismo Ofensivo (Mearsheimer 2001), ou o Realismo Clássico (Morgenthau, 1951). As características centrais do realismo são as assunções de "grupismo" (WOHLFORTH, 2008, p. 133), que envolve entidades estatais semelhantes a estados; os interesses comuns "egoístas" dessa entidade; seu medo de perder segurança baseado na anarquia internacional; ganhos relativos nas relações internacionais, e a primazia do poder (KIRSHNER, 2010, p. 55). "Quando a segurança física parece garantida" (KIRSHNER, 2010, p.55) - uma situação real entre as grandes potências no século XXI - entidades semelhantes a estados tem outros objetivos, por exemplo econômicos. Buscando esses objetivos, a UE como ator nas relações econômicas externas depende na PEC altamente comunitarizada, de que a Comissão é responsável. (DREZNER, 2007)

\footnotetext{
26 As referências frequentes a "política externa realista" indicam uma confusão relativamente generalizada do explanandum e do explanans. Embora os dois sejam inter-relacionados, o realismo simplesmente não pode ser tanto explanandum, como explanans, ser o que ele busca explicar, ser a política de poder, e explicar a dinâmica de política de poder. Uma segunda parte do problema conceitual é o emprego casual generalizado do conceito de política de poder, isto é, sua sub-específicação severa. (JORGENSEN, 2016, p. 94)
} 


\subsection{Conceitos-chave}

Os entendimentos clássicos sobre política externa da UE reduziriam seu escopo à PESC (Política externa e de segurança comum) apenas. Entretanto, uma visão mais ampla de "política externa" deve ser levada em conta ao lidarmos com a UE (COSTA, 2017). Por regras gerais, três principais componentes servem como base para a política externa da UE: a PESC (incluindo a PSDC); as políticas externas da União, como o comércio; e a dimensão externa das políticas internas, como energia, meio ambiente/mudanças climáticas, migração, entre outros aspectos. Assim, comércio exterior não significa apenas comércio. Possui implicações profundas na política externa e fornece à União uma ferramenta de política externa valiosa (COSTA, 2017, p. 192).

O poder econômico sempre esteve intimamente relacionado ao poder político e também ao poder militar, tendo em vista que o sucesso econômico influencia significativamente a habilidade dos estados de aumentar seu equipamento militar, força, e adicionalmente sua influência política em negociações e processos internacionais de tomada de decisão. Consequentemente, a posição internacional forte da UE pode ser pelo menos parcialmente explicada com a força econômica da União. (SCHWARZKOPF, 2016, p. 25)

O Realismo Comercial engloba duas variáveis independentes extra regionais: atores rivais e a coesão da região homóloga. Ambas são variáveis ordinais variando de baixo a alto. No caso dos atores rivais, o escopo de suas relações comerciais varia entre limitado e amplo, enquanto que no caso da região homóloga, seu grau de coesão varia entre baixo e alto. Ambas as variáveis incluem um elemento quantitativo no sentido de que a amplitude das relações comerciais dos atores rivais é medida pelas questões comerciais (implicadas) em suas relações, e que a coesão da região homóloga é medida por um índice de quinze indicadores. (MEISSNER, 2016, p. 101) 


\section{Atores rivais}

A definição de um ator rival ou de uma grande potência é relacional ${ }^{27}$. O critério de interesse, para o Realismo Comercial é aquele de indicadores econômicos. Um dos indicadores mais comuns e mais frequentemente usado para poder econômico no mundo é o Produto Interno Bruto (PIB), um indicador em que o Realismo Comercial se baseia. A variável atores rivais é medida pela amplitude de suas relações comerciais ${ }^{28}$. Operacionalizando essa amplitude, o número de questões de comércio incluídas em suas relações com a região homóloga define seu escopo. Quanto mais questões os atores rivais implicam em suas relações com a região homóloga, mais amplas suas interações de comércio são. (MEISSNER, 2016, p. 102)

De acordo com a perspectiva do Realismo Comercial, as relações dos atores rivais com a região homóloga podem ser quantificadas pelo volume de comércio entre essas unidades e a região em questão. Ao longo do tempo, a UE tornou-se crescentemente profissional em observar atores rivais porque ela colabora agora com suas delegações nessas regiões e com o SEAE. Essas instituições consequentemente adicionam pessoal aos recursos da $\mathrm{UE}^{29}$. A qualidade de tal competição, explica Meissner (2016, p.309),

\footnotetext{
27 A assunção da abordagem da geoeconomia - amplamente inserida na tradição realista - é que entidades unitárias, ou a UE, competem com atores rivais para fortalecerem suas posições relativas (GROSSE, 2014; LUTTWAK, 1990; MATTLIN \& WIGELL, 2016). No entanto, boa parte desse processo ocorre na esfera econômica, ao invés da militar. Portanto, a UE "usa" países menos desenvolvidos, como uma esfera para gerar benefícios comerciais e influência política vis-à-vis competidores diretos, como os EUA. E, desta forma, o inter-regionalismo desempenharia papel instrumental para a posição de poder do bloco europeu, em outras regiões, vis-à-vis atores rivais (MEISSNER, 2017).
}

${ }^{28}$ Ainda conforme Meissner enfatiza, em 2001, à frente dos países europeus, os EUA e o Japão eram as potências econômicas mais importantes. Em 2007, a China ocupava a terceira posição, atrás dos EUA e Japão, mas à frente dos países europeus. Em 2010, a China havia superado mesmo o Japão e então eram os EUA, a China e o Japão à frente dos países Europeus. Como consequência, Meissner (2016, p. 102) tratam os EUA e o Japão como os atores rivais da UE até 2007, e depois de 2007 os EUA, o Japão e a China.

${ }^{29}$ Helwig et al. (2013, p. 43) indicam que a relação contenciosa entre a DG comércio e a antiga DG RELEX, considerado um exemplo clássico de rivalidade burocrática da UE, foi amplamente transposto ao novo quadro institucional. Um relatório da Civil Society Dialogue Network (CDSN 2013, p. 3) revela 
“[...] difere entre os atores rivais. Com os EUA, essa competição é mais abrangente porque a UE compete para ter relações econômicas privilegiadas, para mostrar presença em regiões terceiras, e para estabelecer padrões regulatórios. Com a China, a competição é menos abrangente porque se foca em relações econômicas privilegiadas na forma de investimentos, comércio em bens, e matérias-primas."

Ademais, conforme sublinhamos no capítulo anterior, essas negociações com atores rivais e potências emergentes às vezes exibem uma configuração de soma-zero, e em outros casos uma configuração de soma positiva. Empiricamente, o comércio em bens parece ser uma situação em que a lógica de soma-positiva se aplica, ao passo que questões de propriedade intelectual e regulatórias, estão mais associadas a uma configuração de soma-zero (MEISSNER, 2016, p. 246).

\section{$\underline{\text { Região }}$}

De acordo com Meena (2013, p. 586), tentativas recentes de conceitualizar região têm enfatizado o valor de estabelecer suas conexões com o espaço e lugar. Por exemplo Allen et. al. (2002) avançam dois princípios para definir/conceitualizar região: primeiro, engloba uma abordagem fortemente relacional de pensar sobre o espaço e o lugar. Isto é, entende tanto o espaço e lugar como constituídas a partir de relações sociais especializadas - e narrativas a respeito delas - que não apenas formam geografias regionais sempre novas, mas também trabalham para remoldar identidades sociais e culturais e como são representadas. Segundo, reconhece que tais estudos são sempre feitos para um propósito, com um objetivo específico

que a DG Comércio resiste de forma bem sucedida a integrar-se na ação externa da UE baseada na crença de que o comércio deveria ser utilizado estritamente para defender os interesses econômicos europeus e não para avançar objetivos mais amplos de política externa. (BOSSUYT. ET. AL 2018, p. 5) 
em vista. Seja teórico, político, cultural, ou o que quer que seja, sempre há um foco específico.

(ALLEN et al., 2002, p. 2).

Conforme Meena (2013, p. 585) explica,

"a etimologia do termo "região" (region em inglês) remonta ao século 14, quando evoluiu da palavra Latina regio, que significa direção, fronteira, ou distrito, relacionado a regere, significando dirigir ou dominar (TOMANEY, 2009, p. 136). A geografia, como uma disciplina, tem testemunhado um foco sustentado no estudo de regiões, mas um tema recorrente e constante é que as regiões exibem homogeneidade em termos de várias características, e isso as define como regiões. As regiões em geografia também são marcadas por uma distinção peculiar de regiões "formais" e "funcionais". Regiões formais ou uniformes são áreas definidas por uma ou mais das características que ocorrem dentro delas (TOMANEY, 2009, p. 140). A região funcional ou nodal é um sistema espacial geograficamente delimitado, definido pelas conexões unindo fenômenos particulares naquela área. Quais fenômenos? Depende de qual Sistema estamos interessados em examinar (TOMANEY, 2009, p. 140)".

Por região política, Soderbaum (2015, p. 6) refere-se a um grupo de unidades políticas, que tem, mais ou menos ambiciosamente, entrado em algum tipo de cooperação com propósito, a forma mais simples sendo um sistema de alianças ou pacto comercial, mas também abrangendo formas mais profundas de unificação. Regiões políticas nesse sentido tem estado conosco ao longo da história política humana, embora seja difícil diferenciar entre o que era um "estado" e uma "região" na era pre-Vestfaliana. Uma distinção relevante nesse contexto pode ser feita entre integração coercitiva e voluntária para criar uma região política.

O inter-regionalismo é uma área de pesquisa relativamente nova. No entanto, diversos estudos importantes foram realizados e que tentam identificar os fatores que explicam sua emergência como um nível distinto de interação e os papéis específicos que poderia desempenhar (AGGARWAL AND FOGARTY, 2004; DOIDGE, 2011; HÄNGGI, 2000, 2006; HÄNGGI, ROLOFF \& RÜLAND, 2006; HARDACRE AND SMITH, 2009; SODERBAUM \& VAN LANGENHOVE, 2005; RÜLAND, 2010). 
Ao considerar a região homóloga, o Realismo Comercial assume três atores no sistema internacional: a UE, atores rivais, e a região homóloga, que pode consistir em um estado regional principal e em outros estados emergentes ou em desenvolvimento. A UE discrimina entre os atores rivais e os membros da região homóloga. Enquanto a UE compete com atores rivais, ela usa os estados membros da região homóloga instrumentalmente para incrementar seu poder econômico e crescimento. Quando os atores rivais estão presentes e quando a UE compete com eles, ela altera o desenho da PEC no que se refere a arenas de acordo com a região homóloga. Os resultados da PEC em relação a arenas, que o Realismo Comercial leva em consideração são o inter-regionalismo e o bilateralismo. (MEISSNER, 2016, p. 71)

\section{Coesão}

Na formulação de Keohane (2006, p.81) a coesão ocorre "quando os atores ajustam seu comportamento às preferências reais ou antecipadas de outros por meio de um processo de coordenação de política". Meissner (2017) desenvolveu um índice com 15 indicadores para aproximar-se empiricamente do conceito de coesão. O índice, que foi desenvolvido de acordo com uma lógica cumulativa, engloba desenvolvimentos refletindo espírito de equipe (coesão) dentro de organizações regionais:

"A fim de destacar indicadores, a literatura existente sobre o conceito de ator (Jupille and Caporaso 1998; Murau and Spandler 2016; Wunderlich 2012) e coesão (Aggarwal and Fogarty 2004; Da Conceição-Heldt and Meunier 2014), foi consultada. Baseando-se nessa literatura, foram derivados componentes que englobam a dinâmica de competitividade dentro de organizações regionais para além da Europa. Essas organizações, em oposição à UE altamente integrada, tem uma pontuação baixa na condição de ator (actorness) (Hooghe and Marks 2015, 310), e é por isso que indicadores foram necessários para refletir sua habilidade e vontade de aparecer como um grupo" (Meissner, 2017). 
Conforme Meissner (2016, p. 104) enfatiza, politicamente a coesão aparece em um contexto intra-regional e extra-regional. Assumindo que as disputas intra-regionais refletem divergência de preferências, a coesão política engloba o número de disputas (1), sua intensidade (2), e sua solução (3), se os estados membros as resolvem dentro ou fora da organização. Correspondendo à autoridade, isto é, a habilidade de falar em nome de um grupo (JUPILLE \& CAPORASO, 1998), e autonomia, ou seja, a capacidade de agir externamente (DA CONCEIÇÃO-HELDT AND MEUNIER 2014, p. 965), a coesão política intra-regional inclui o estabelecimento de instituições supranacionais (4), o aprofundamento de instituições (5), e o alargamento de instituições (6). A coesão política extra-regional, ao corresponder ao reconhecimento internacional por meio de pertencimento organizacional a instituições internacionais, capacidade de ator, ou reconhecimento de fato por atores terceiros (DA CONCEIÇÃO-HELDT AND MEUNIER 2014), materializa-se por meio da união em instituições internacionais (7), união em setores não-regulados (8), e união em encontros presidenciais (9). Complementando a coesão política, a coesão econômica manifesta-se como antecipada ou material de preferências. Medindo uma divergência de preferências, a coesão econômica engloba: prioridades sobre o parceiro de negociação (10), o tema de negociação (11); divergência ou convergência de comércio (12) e investimento pelo parceiro de negociação (13); e divergência ou convergência do tipo de comércio (14) e do tipo de investimento (15). 
Tabela 2 Índice de coesão desenvolvido por Meissner

\begin{tabular}{|c|c|c|}
\hline \multicolumn{2}{|r|}{ Indicador } & Pontuação \\
\hline \multirow{6}{*}{$\begin{array}{l}\text { Política } \\
\text { Intra-Regional }\end{array}$} & Número de disputas comerciais (1) & \\
\hline & Intensidade de disputas comerciais (2) & \\
\hline & Solução de disputas comerciais (3) & \\
\hline & Instituições supranacionais (4) & \\
\hline & Aprofundamento de instituições (5) & \\
\hline & Alargamento de instituições (6) & \\
\hline \multirow{5}{*}{$\begin{array}{l}\text { Política } \\
\text { Extra-regional }\end{array}$} & $\begin{array}{l}\text { Unidade em instituições internacionais } \\
\text { (7) }\end{array}$ & \\
\hline & Unidade em áreas não-reguladas (8) & \\
\hline & Unidade em cúpulas presidenciais (9) & \\
\hline & Prioridade de parceiro de negociação (10) & \\
\hline & Prioridade de matéria de negociação (11) & \\
\hline \multirow{4}{*}{$\begin{array}{l}\text { Assuntos } \\
\text { Econômicos }\end{array}$} & Convergência de comércio (12) & \\
\hline & Investimento por parceiro (13) & \\
\hline & Tipo de comércio (14) & \\
\hline & Tipo de investimento (15) & \\
\hline Soma & & \\
\hline
\end{tabular}

Fonte: Meissner (2016, p. 105) 
Porém, em coalizões o aspecto da supranacionalidade não se aplica, e, portanto, o índice desenvolvido por Meissner (2016) pode ser adaptado, passando a ser integrado apenas por 12 indicadores, após a subtração dos elementos instituições supranacionais (4); aprofundamento de instituições (5); e alargamento de instituições (6), conforme a ilustração abaixo:

Figura 2: Índice de coesão de Meissner adaptado para coalizões

\begin{tabular}{|c|c|c|}
\hline Coesão & Indicador & Pontuação \\
\hline \multirow{6}{*}{$\begin{array}{l}\text { Política } \\
\text { Intra-Regional }\end{array}$} & Número de disputas comerciais (1) & \\
\hline & Intensidade de disputas comerciais (2) & \\
\hline & Solução de disputas comerciais (3) & \\
\hline & Instituições supranacionais (4) & - \\
\hline & Aprofundamento de instituições (5) & - \\
\hline & Alargamento de instituições (6) & - \\
\hline \multirow{5}{*}{$\begin{array}{l}\text { Política } \\
\text { Extra-regional }\end{array}$} & $\begin{array}{l}\text { Unidade em instituições internacionais } \\
\text { (7) }\end{array}$ & \\
\hline & Unidade em áreas não-reguladas (8) & \\
\hline & Unidade em cúpulas presidenciais (9) & \\
\hline & Prioridade de parceiro de negociação (10) & \\
\hline & Prioridade de matéria de negociação (11) & \\
\hline \multirow{4}{*}{$\begin{array}{l}\text { Assuntos } \\
\text { Econômicos }\end{array}$} & Convergência de comércio (12) & \\
\hline & Investimento por parceiro (13) & \\
\hline & Tipo de comércio (14) & \\
\hline & Tipo de investimento (15) & \\
\hline Soma & & \\
\hline
\end{tabular}




\subsection{Implicações}

O estilo de política comercial da UE e a maneira que emprega todos os instrumentos à sua disposição parecem os de uma grande potência: construídos não em torno de persuasão, mas pelo contrário ao redor de ameaças, sanções e demandas (KERREMANS \& ORBIE 2009, p. 629). A UE oferece incentivos e punições por meio do comércio para encorajar seus alvos a aquiescer, e emprega seu poder estrutural para pedir concessões daqueles que desejam ganhar acesso ao seu mercado (SMITH, 2006, p. 532). Conforme Galtung já notou em 1973, acordos bilaterais ou regionais entre uma união aduaneira de estados europeus altamente desenvolvidos e vários grupos individuais ou regionais deverão conferir um nível significativo de poder estrutural para o centro em relação à periferia (GALTUNG, 1973). (BURCKHARDT, 2013, p. 279)

Conforme enfatizado nos capítulos anteriores da tese, as negociações inter-regionais de APCs da UE tem falhado na maioria das vezes, devido à existência de obstáculos similares àqueles que impediram a conclusão de novos acordos multilaterais desde a metade dos anos 1990. Sob os termos da estratégia do Global Europe, a UE exige concessões WTO + amplas de seus parceiros de negociação de APCs. Ao mesmo tempo, no entanto, a própria UE tem-se

provado continuamente resistente a atender as demandas de seus parceiros por maior liberalização em setores sensíveis, como a agricultura. A esperança era que as negociações no nível inter-regional serviriam para facilitar o acordo por meio de números reduzidos; no entanto, na maioria dos casos isso não se mostrou ser o caso. MCCROSSAN (2014) não encontrou evidência de que o interregionalismo da UE tenha desempenhado as funções de racionalização e formação de agenda propostos na literatura. (Rüland, 2002, 2010). (MCCROSSAN, 2014, p.11) 
Embora a UE possa não ser um ator "unitário" de verdade, o nível de autonomia garantido à Comissão a capacita a comportar-se como tal. Em termos da escolha de buscar acordos preferenciais mais especificamente, Aggarwal \& Fogarty (2004, p. 12) argumentam que os formuladores de política da UE podem ser mais inclinados a favorecer APCs interregionais e bilaterais devido ao fato de que, como parceiro dominante nesses arranjos, a UE é mais capaz de exercer sua alavancagem em comparação com o ambiente de negociação multilateral crescentemente complexo (MCCROSSAN, 2014, p. 53).

Assim, é possível sintetizar os valores para o desenho de política comercial, e sua relação com fatores extra-regionais por meio do quadro a seguir:

Tabela 3: Resultados de acordo com o Realismo Comercial.

\begin{tabular}{|l|l|l|}
\hline & Coesa & Não Coesa \\
\hline $\begin{array}{l}\text { Rivais: relações } \\
\text { amplas }\end{array}$ & $\begin{array}{l}\text { Inter-regionalismo } \\
\text { abrangente }\end{array}$ & Bilateralismo abrangente \\
\hline $\begin{array}{l}\text { Rivais: relações } \\
\text { limitadas }\end{array}$ & $\begin{array}{l}\text { Inter-regionalismo } \\
\text { seletivo }\end{array}$ & Bilateralismo seletivo \\
\hline
\end{tabular}

Fonte: Adaptado e traduzido a partir de Meissner (2016, p. 79)

\subsection{Ferramentas teóricas a serem utilizadas}

As relações interregionais tem frequentemente sido examinadas em relação à sua capacidade de agir como território intermediário entre os níveis global e regional. Nesse sentido, cinco papéis potenciais amplos foram atribuídos ao processo (HÄNNGI, 2006; RÜLAND, 2002, 2010). Esses são: equilíbrio, construção de instituição, racionalização, formação de agenda, e construção de identidade coletiva. (MCCROSSAN, 2014) 
De uma perspectiva realista, a UE deveria preferir negociações ou relações seletivas. Com um alcance seletivo de questões, a UE pode distinguir entre interesses ofensivos e defensivos nas relações comerciais, e pode, portanto, entrar em relações comerciais favoráveis e privilegiadas que excluem interesses europeus defensivos, tais como agricultura. Os atores rivais ao contrário prefeririam que a UE não tivesse relações comerciais com estados regionais centrais, ou países em desenvolvimento, porque qualquer relação de comércio privilegiada pode impedir o poder e potencial de crescimento de um ator rival. (MEISSNER, 2016, p. 65).

\begin{tabular}{|l|l|}
\hline Ator & Preferência em relação a resultado \\
\hline EU & Desenho inter-regional \\
\hline Ator rival & Ausência de relações comerciais \\
\hline Região homóloga & Variação de acordo com a coesão \\
\hline
\end{tabular}

Fonte: Meissner (2016, p. 72)

Também em uma abordagem realista, a UE prefere negociações bilaterais àquelas interregionais. Nas relações bilaterais, a UE pode fazer uso de seu poder de mercado assimétrico. A UE tem, assimetricamente, força comercial considerável vis-à-vis países emergentes ou em desenvolvimento porque ela consiste em países industrializados e porque também é uma acumulação de economias. Esse poder econômico assimétrico dá à UE poder de barganha assimétrico em negociações internacionais ou relações comerciais (HERON 2011; MEUNIER AND NIKOLAÏDIS 2006; CONCEIÇÃO-HELDT, 2014). Para se beneficiar completamente desse poder de barganha, a UE deve negociar ou lidar com países individuais bilateralmente. Em relações inter-regionais, no entanto, os países em desenvolvimento podem equilibrar o poder de barganha da UE por meio da formação de grupos. (MEISSNER, 2016, p. 71)

As negociações de comércio são disputas competitivas entre grandes potências também por uma razão adicional: 
“ $\mathrm{O}(\mathrm{s})$ parceiro(s) respectivos jogam os atores em competição uns contra os outros ao usar estrategicamente negociações simultâneas. Os países em desenvolvimento ou emergentes tem a possibilidade de atrair mais (pelo menos dois) parceiros de negociação ao mesmo tempo, e prolongar essas negociações a fim de extrair o máximo das conversas. Ao negociar simultaneamente com mais atores, o(s) estado(s) podem insistir em condições melhores e pode incluir certos assuntos pertinentes - à exclusão de outros, a fim de conversar sobre pacotes favoráveis completos de tópicos prevalecentes." (MEISSNER, 2016, p. 72)

A teorização realista (Realismo Comercial) tem alavancagem analítica para explicar a elaboração de política comercial da UE. Em sua PEC em relação à América do Sul e Sudeste Asiático, a mudança da UE para o bilateralismo pode ser melhor explicada por sua motivação de assegurar poder econômico e regulatório nessas regiões, bem como os graus variáveis de coesão dessas regiões. Essa explicação foi corroborada pela mudança da UE de interregionalismo para bilateralismo com a CAN na América Latina. Conforme (MEISSNER, 2016, p. 313) enfatiza, a alavancagem do Realismo Comercial nesses casos mostra que a teorização realista sobre a política externa comercial da UE e sobre comércio internacional faz sentido, e deveria ser reconhecido como uma explicação alternativa para aquela oferecida pelo quadro do agente-principal e pelo liberalismo comercial. 


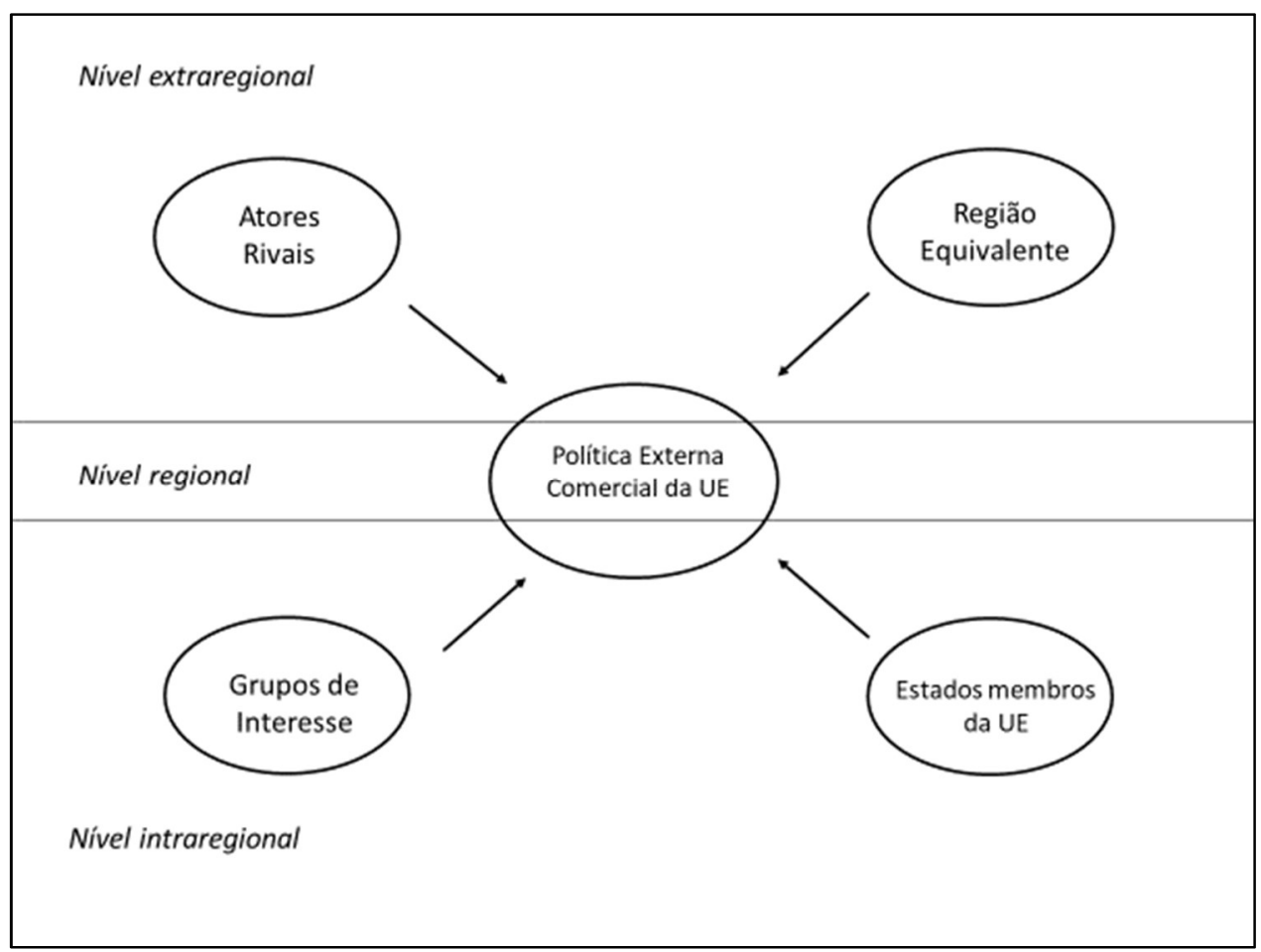

Fonte: Meissner (2016, p. 55)

A diferença entre o conjunto de variáveis extra-regionais e intra-regionais faz paralelo, grosso modo, às diferenças entre as escolas liberal e realista. Enquanto os realistas enfatizam preocupações com segurança, os liberais enfatizam a cooperação na arena internacional e os ganhos de bem-estar derivados do comércio. Alguns dos primeiros teóricos da escola liberal chamavam a si mesmo de "utópicos" ou "idealistas", enquanto Edward Carr (1939) rotulavaos de "moralistas". (MEISSNER, 2016, p. 58). Conforme enfatizado na introdução deste trabalho, no modelo teórico utilizado nesta tese, mantém-se as varáveis extra-regionais do Realismo Comercial - porém - no que se refere a variáveis intra-regionais, são analisadas as preferências das instituições da UE e o quadro estratégico da coerência da política comercial do bloco com a política externa europeia. 


\subsection{Crítica ao quadro teórico}

Conforme Burckhardt (2013, p. 274) aponta, o argumento de que a UE prioriza interesses acima de valores em sua política comercial deve ser qualificado em três aspectos. Primeiro, a proximidade geográfica, elegibilidade para adesão à UE, e o nível de desenvolvimento do parceiro de negociação importam, é claro. Espera-se que as motivações comerciais sejam as mais fortes - ceteris paribus - ao lidar com economias industrializadas fora da vizinhança imediata da UE, e mais fracas ao lidar com economias em desenvolvimento próximas à Europa, tais como os países do Mediterrâneo ${ }^{30}$ (WOOLCOCK 2007, p.2). Segundo, a distinção entre valores e interesses em áreas como proteção ambiental, direitos sociais e padrões de saúde e de segurança é praticamente impossível. Terceiro, a posição da UE em um número limitado de questões de comércio, tais como o acordo TRIPS na rodada Doha, poderia de fato ter sido influenciada por considerações normativas (ADRIAN VAN DEN HOVEN 2006, p. 191). No entanto, na maioria das questões, uma distinção entre valores e interesses é possível, e a União opta pelos últimos na maioria dos casos

Uma leitura neo-realista da política externa da UE poderia concluir que a UE está jogando potências regionais contra potenciais desafiadores a fim de forjar relações fortes e, como resultado, fortalecer a posição e papel da Europa dentro dessas regiões. Mas, tendo em vista a história e a identidade regional da UE, é difícil de acreditar que ela esteja desenvolvendo parcerias bilaterais para colocar em xeque sua abordagem inter-regional. É um fato, no entanto,

\footnotetext{
${ }^{30}$ Também cabe lembrar as limitações ao conceito de geoeconomia, enfatizadas por Meissner (2017, p. 14). Um entendimento amplo da geoeconomia pode estar em tensão com assunções-chave da teorização realista em que ele está ancorado. Enquanto uma versão estreita da geoeconomia, por exemplo o equilíbrio de poder, reconhece a importância dos ganhos relativos, a compreensão ampla, isto é, a competitividade, permite que os atores persigam ganhos econômicos absolutos vis-à-vis o parceiro de negociação. Essa observação joga luz sobre uma ambiguidade conceitual da geoeconomia que se origina na escola realista de pensamento
} 
que há uma tensão entre as duas abordagens, e há indicações que essas parcerias bilaterais poderiam reforçar rivalidades e forças centrífugas dentro das regiões respectivas. (RENARD, 2015, p. 29).

O Neorrealismo tem dificuldade em explicar por que os estados membros da UE concordam voluntariamente em ceder certas responsabilidades de suas políticas externas, de segurança e defesa para instituições supranacionais tais como o SEAE e a Comissão Europeia. O Neorrealismo também acha problemático explicar o fato que iniciativas como a PCSD foram largamente desenvolvida em um contexto político em que não havia ameaça iminente à segurança na Europa. A conferência de Saint-Malo, que deu origem à PCSD ocorreu em 1998, e portanto após a queda da União Soviética. A PCSD nasceu da frustração que derivou da inabilidade da Europa de responder efetivamente à desintegração da Iugoslávia e seu resultado. $(\text { FIOTT, 2017) })^{31}$

Em seguida, é importante enfatizar que o Realismo Comercial considera os atores rivais (e os Estados) como caixas-pretas, isto é, não analisa dinâmicas domésticas a essas unidades. Assim, embora essa simplificação contribua para a parcimônia da teorização desenvolvida, deve ser criticada devido a fatores, como o papel de líderes, ou a interdependência econômica, que tem papel determinante na relação da UE com atores terceiros. E apesar de emendas significativas de várias escolas "neo", o realismo ainda sofre de inconsistência empírica (JORGENSEN, 2016; LEE, 2018). Consequentemente,

${ }^{31}$ Outro elemento de crítica à abordagem realista, e mais especificamente à teoria do Realismo Comercial, pode-se centrar em sua postulação de que a política comercial da UE teria mudado seu enfoque no caso do MERCOSUL para um relacionamento mais próximo ao Brasil. Embora a assinatura da parceria estratégica em 2007 represente sem dúvida um esforço de maior aproximação com o parceiro Latino-Americano, o foco da política comercial do bloco europeu manteve-se no nível regional. 
"não há espaço para otimismo no que se refere ao futuro do realismo. [...] Uma teoria problemática vai eventualmente perder sua atração frente a seu público com ou sem a emergência de uma teoria melhor. Se o realismo é incapaz de reajustar sua concepção de poder, ao levar em conta teoricamente a importância igual de outras faces do poder e empiricamente olhar para resultados internacionais além do ocidente, será difícil esperar um rejuvenescimento" (LEE, 2018, p. 51).

Justamente, são raras as análises das relações da UE com os BRICS, ou que analisam a ausência de uma estratégia europeia para a transição de poder em curso na arena internacional. Mesmo a tese do Realismo Comercial encontrou diferentes configurações das negociações da EU com potências emergentes: às vezes são caracterizadas por um quadro de soma-zero; e as vezes de soma-positiva. E essa reformulação do realismo também ignora completamente o impacto que a emergência desses atores tem tido sobre o projeto de integração europeu, igualmente afetado pela crise econômica desde 2008 e pela crise migratória em anos mais recentes.

Desta forma, a seção seguinte do capítulo desenvolve as hipóteses centrais da tese, que buscam trazer uma resposta às perguntas de pesquisa enunciadas na introdução do trabalho, bem como complementar aspectos do Realismo Comercial que demandam explicação adicional. Igualmente, o modelo teórico adotado incorpora elementos de trabalhos recentes que também investigaram a ação externa da UE no nível inter-regional, e em sua relação com a política comercial do bloco. 


\subsection{Hipóteses}

Partindo-se da premissa de que está em curso um reequilíbrio da ação externa da UE, atribuindo maior peso à esfera bilateral, em detrimento das dimensões inter-regional e multilateral, retomam-se as perguntas de pesquisa enunciadas na introdução do projeto:

A) Por que a UE tem feito uso crescente de instrumentos bilaterais na arena de comércio internacional?

B) Qual a inter-relação, a nível europeu, entre as políticas para as arenas bilateral, interregional e multilateral? Como difere a formulação de política para essas arenas?

Hipótese (forma geral):

A UE ajusta o desenho de sua política comercial em resposta à ação de atores rivais e à coesão da região homóloga, mas tendo em vista que não dispõe de uma estratégia para a ascensão de novas constelações de atores na arena internacional, não monitora de forma sistemática a atuação desses atores. Assim, a busca por acordos preferenciais de comércio pode não servir a objetivos políticos mais amplos do bloco - isto é - pode estar em conflito com a política externa do bloco. 


\section{Hipótese}

Conforme enfatizado na introdução do trabalho, a UE tem crescentemente feito uso de instrumentos bilaterais na esfera comercial, com o objetivo de atingir metas econômicas, e distanciando-se cada vez mais do formato sui generis que os acordos de primeira geração tinham. Esse fato ficou particularmente evidente a partir da publicação do documento Global Europe de 2006. A DG Comércio da Comissão, por meio de suas diferentes seções, monitora oportunidades na arena internacional e pede autorização ao Conselho para iniciar negociações com países e regiões terceiros.

A DG Comércio desempenha papel especial no processo decisório em política comercial da UE, e o tratado de Lisboa buscou trazer maior coerência entre esse departamento e outros órgãos de ação externa do bloco ${ }^{32}$. Portanto os atores no nível europeu avaliam e monitoram a evolução dos processos e dinâmicas na $\mathrm{OMC}$, que constitui o núcleo do regime internacional de comércio, porém também nos demais componentes desse regime: áreas de livre comércio, acordos em setores específicos, acordos minilaterais, etc.

Assumindo a efetiva coordenação intra-institucional na UE, o bloco europeu planeja e responde a esses inputs respeitando os objetivos de política externa mais amplos do bloco. Portanto, caso haja disfuncionalidade na concepção da estratégia europeia de ação externa ${ }^{33}$, ou

\footnotetext{
${ }^{32} \mathrm{Na}$ literatura, "coerência é geralmente conceituada como denotando tanto a ausência de contradições entre diferentes área de política exterior e a criação de uma sinergia entre elas (GAUTTIER 2004, pp. 23, 26; GEBHARD 2011, p. 106; VAN ELSUWEGE 2010, pp. 1013-1014). Isso integra a distinção de Nuttall (2005,pp. 96-97) entre coerência "neutral" e "benigna". Enquanto o primeiro refere-se à ausência de contradição entre políticas, coerência "benigna" ou "sinergética" aponta para uma interação positiva e desejável, e suas respectivas burocracias, unidas ao "serviço de um propósito comum" (NUTTALL 2005, pp. 96-97; GEBHARD 2011, pp. 111-112) (BOSSUYT ET AL, 2018, p. 3)
}

${ }^{33}$ Nitoiu \& Sus definem estratégia como o resultado amplo, estruturado e sistemático de processos que visam identificar vários problemas de política, desafios ou oportunidades, fornecer soluções para eles e definir metas e expectativas (ROCHEFORT, 1994; BIRKLAND, 1997). O aspecto chave que define uma estratégia é o fato que ela apresenta um quadro maior que pode guiar coerentemente e sistematicamente a formulação de política em vários níveis. Criar uma estratégia implica ir além de construir várias políticas e planos. Isso engloba a existência de um conjunto coerente de objetivos e 
na sua efetiva implementação, isso deverá se verificar na política comercial do bloco, e também no quadro das parcerias estratégicas. O que leva à hipótese seguinte:

1) Na ausência de uma estratégia europeia para o reequilíbrio de poder na arena internacional, a UE terá maior probabilidade de fazer uso de instrumentos bilaterais na arena de comércio

Parte-se da assunção de que a UE não tem, atualmente, uma estratégia para responder à transição de poder em curso na arena internacional, bem como à emergência de novas constelações de atores na governança global - isto é, apenas o componente de defesa da EUGS tem sido implementado de forma efetiva pela organização (SUS, 2017).

A ascensão de novas potências econômicas representa um desafio de nova magnitude para a ação externa da UE, ao qual o aparato diplomático fragmentado europeu é incapaz de dar uma resposta adequada (NARLIKAR, 2013). Assim, ao expor o mecanismo causal da hipótese 1, inicialmente enfatiza-se que a UE monitora a formação e atuação de novos atores na arena internacional. Uma implicação observável dessa proposição do mecanismo causal seria, assim, a elaboração de relatórios, estudos, pronunciamentos em nível doméstico europeu, sobre a atuação comercial de grupos de países emergentes.

Um conjunto de evidências que desconfirma essa parte do mecanismo causal seria, por outro lado, a falta de atenção da UE em relação a essas coalizões de países, a não produção de estatísticas, regularmente, sobre o comércio exterior desses atores. Igualmente, a expectativa é que houvesse referências raras a esses grupamentos em documentos-chave da estratégia da UE para assuntos internacionais.

idéias que possam guiar os formuladores de política ao lidar com a realidade política (EISING ET AL. 2015) 
Um segundo elemento do mecanismo causal refere-se às discussões no âmbito do Conselho $^{34}$ sobre a necessidade de adotar política específica para grupos de novas potências econômicas e políticas. Assim, ao longo do processo de formulação de política comercial, a UE dedica corriqueiramente atenção a regiões terceiras, objetivando um acordo abrangente com essas regiões. Portanto, uma implicação observável dessa parte do mecanismo causal seria a ausência de agenda para a adoção de uma estratégia coerente para a ascensão de novas potências e sua ação concertada no âmbito de coalizões.

Evidência contrária a essa etapa do mecanismo causal seria a presença de recomendações específicas, por parte do conselho, para que os acordos, e outros elementos da política comercial europeia, levassem em consideração os possíveis efeitos da ação concertada de países emergentes. Igualmente, esperar-se-ia que o Conselho, em conjunto com o SEAE, também produzisse avaliações nesse sentido.

O terceiro elemento do mecanismo causal refere-se à efetiva escolha da UE em negociar acordos bilaterais de comércio. Quando a segurança física de um país parece garantida, uma situação de fato para a UE no século XXI, o estado pode se dedicar a assegurar seus interesses na esfera econômica (MEISSNER, 2016). Assim, um dos instrumentos à disposição da UE para fazer avançar seus interesses econômicos e garantir o acesso a mercados e recursos estrangeiros, para companhias europeias, é por meio da assinatura de um APC (acordo preferencial de comércio). Portanto a Comissão avalia o progresso de negociações regionais, bem como o potencial de conclusão de acordos de livre comércio nessa esfera, e assim pode iniciar negociações no nível bilateral - a fim de evitar que atores rivais antecipem-se e garantam melhor condições de acesso a esses mercados.

\footnotetext{
${ }^{34}$ Conforme McCrossan (2014) explica, o Conselho tem buscado expandir a influência da UE em um
} sentido geopolítico e geoeconômico por meio de mais ação coerente no nível regional. 
No entanto, na ausência de uma efetiva estratégia europeia para as novas realidades econômicas e geopolíticas, pode haver incoerência entre a política comercial e a política externa do bloco. Portanto, uma implicação observável desse aspecto do mecanismo causal seria, inicialmente, a desarticulação da estratégia europeia, identificável por meio de documentos oficiais da UE, bem como pela não atuação da UE em questões emergentes na arena internacional. Em seguida, a UE faz avançar a cooperação com países-alvo no nível bilateral, no quadro de parcerias estratégicas, mas sem uma compreensão adequada dos interesses e contexto regional desses países.

Evidência que desconfirma essa parte do mecanismo causal seria a ausência de articulação estratégica da UE, acompanhada pela iniciação de negociações bilaterais que sejam coerentes com os objetivos europeus mais amplos na arena internacional: estabilidade; fortalecimento do multilateralismo; desenvolvimento internacional; proteção aos direitos humanos, aprofundamento de processos de integração regional, entre outros aspectos. 


\begin{tabular}{|l|l|l|}
\hline Mecanismo causal & Implicação observável & Evidência contrária \\
\hline $\begin{array}{l}\text { Coerência entre política } \\
\text { comercial e política } \\
\text { externa }\end{array}$ & $\begin{array}{l}\text { Articulação entre os } \\
\text { níveis bilateral e regional }\end{array}$ & - \\
\hline $\begin{array}{l}\text { UE monitora a formação } \\
\text { de novos grupamentos de } \\
\text { potências emergentes }\end{array}$ & $\begin{array}{l}\text { Documentos, relatórios, } \\
\text { pronunciamentos dos } \\
\text { chefes da diplom. da UE }\end{array}$ & $\begin{array}{l}\text { Ausência de menção a } \\
\text { coalizões de pot. } \\
\text { Emergentes }\end{array}$ \\
\hline $\begin{array}{l}\text { Discussões no conselho e } \\
\text { SEAE sobre a } \\
\text { necessidade de adotar } \\
\text { política p/ esses grupos }\end{array}$ & $\begin{array}{l}\text { Estados-membros } \\
\text { pressionam por ação }\end{array}$ & $\begin{array}{l}\text { Conselho recomenda a } \\
\text { adoção de política } \\
\text { específica para essas } \\
\text { coalizões }\end{array}$ \\
\hline $\begin{array}{l}\text { UE enuncia a busca de } \\
\text { novos acordos na arena } \\
\text { bilateral }\end{array}$ & $\begin{array}{l}\text { UE inicia negociações no } \\
\text { nível bilateral, em } \\
\text { detrimento das outras } \\
\text { arenas }\end{array}$ & $\begin{array}{l}\text { UE inicia negociações de } \\
\text { acordos bilaterais, apenas } \\
\text { com vias a futura } \\
\text { multilateralização }\end{array}$ \\
\hline $\begin{array}{l}\text { UE adapta o desenho de } \\
\text { sua política comercial }\end{array}$ & $\begin{array}{l}\text { Acordos regionais vs. } \\
\text { bilaterais }\end{array}$ & $\begin{array}{l}\text { Acordos regionais, apesar } \\
\text { de haver vantagens na } \\
\text { esfera bilateral }\end{array}$ \\
\hline
\end{tabular}

Fonte: Dados organizados pelo autor, a partir de adaptação da análise de Meissner (2016)

Hipótese

Ao invés de simplesmente agir como um condutor por meio do qual os Estados Membros e os grupos de interesse buscam atingir seus objetivos, as preferências das instituições da UE podem desempenhar um papel na determinação da política comercial inter-regional (COLEMAN \& TANGERMANN, 1999; GARRET \& TSEBELIS, 1997; VAHL, 1997; WOLL, 2006.) (MCCROSSAN, 2014, p. 18). Embora a posição oficial da UE permaneça aquela de uma abordagem multilateral para a liberalização do comércio sob os auspícios da 
OMC permaneça a prioridade, a competição burocrática em relação à competência de sobre política comercial pode ser um fator importante para se considerar na tentativa de explicar os APCs da UE (AGGARWAL \& FOGARTY, 2004, p. 10) (MCCROSSAN, 2014, p.19)

A UE tem no inter-regionalismo uma de suas principais linhas de ação externa, que levou inclusive ao desenvolvimento de um amplo programa de pesquisa The transformative power of Europe (BORZEL \& RISSE, 2009). Assim, a experiência europeia passou a ser vista como modelo para a integração regional ao redor mundo, obviamente com a devida crítica ao eurocentrismo desse tipo de proposição.

Especificamente na arena de comércio, a Comissão reserva atenção especial aos diferentes grupos regionais - Ásia, Américas, Oceania, Europa, África - não dedicando espaço às diferentes coalizões na arena internacional ${ }^{35}$. Embora tenha centrado seus esforços para acordos de comércio com regiões terceiras, nenhum acordo desse tipo foi concluído pela União Europeia. Assim, em alguns casos a UE tem mudado a ênfase de negociações inter-regionais, para o quadro de parcerias estratégicas com países-chave, visando o aprofundamento da cooperação bilateral nas esferas do comércio, segurança, energia, entre outras.

O caso dos países BRICS é um subgrupo relevante desses parceiros estratégicos da UE, embora apenas no caso da África do Sul a parceria estratégica seja acompanhada de um acordo de livre comércio, assinado em 2002. No jargão da UE, o termo "parceria estratégica” é definido

\footnotetext{
${ }^{35}$ Uma unidade dedicada ao acesso a mercados foi criada dentro da DG comércio, que administra uma base de dados grande listando barreiras estrangeiras por setor, país e tipo de medida. Adicionalmente, a Comissão montou times de acesso a mercado em 39 países terceiros, para monitorar a implementação de acordos de livre comércio (COMISSÃO EUROPÉIA, 2010, p. 12). A estratégia é identificar barreiras estrangeiras às importações da UE, de uma forma abrangente, priorizá-las, e pressionar governos estrangeiros a eliminá-las. (SHAFFER 2006, p. 838; BRETHERTON AND VOGLER 2006, p. 231). (BURCKHARDT, 2013, p. 272). Além disso, enfatiza-se que em Novembro de 2017 a Comissão publicou seu primeiro relatório sobre a implementação de APCs.
} 
de forma relaxada, mas assinala países que, por seus atributos de população, recursos econômicos, territoriais e geopolíticos, representam fonte de interesse especial por parte da UE.

Porém, um aspecto relevante do processo de formulação de política externa comercial a nível europeu, conforme enfatizado pelos trabalhos de Adriansen (2014) e Meissner (2016), é a diversidade de agendas que esses atores tem, e o fato de que estão sendo crescentemente pressionados pelo número de negociações com países terceiros, e a carga de trabalho demandada pelo processo. O que coloca em questão a própria capacidade da DG Comércio de conduzir a política comercial europeia. Desta forma, enfatiza-se que embora o número de acordos bilaterais da UE tenha aumentado na última década, isso não representa uma mudança a nível ideacional dos formuladores de política da UE. Assim, avança-se a hipótese de que:

2) A inexistência de uma preferência clara dos atores institucionais da UE pelo inter-regionalismo ou bilateralismo, na esfera comercial, indica que o bloco não está se distanciando de sua política externa tradicional

Embora empiricamente a UE tenha assinado mais acordos bilaterais desde o fim da década de 2000, a tese do Realismo Comercial não encontrou uma preferência clara dos atores da UE (Comissão, DG Comércio e SEAE), pela arena bilateral ou interregional. Isso questiona a literatura que argumenta que a UE tem se afastado de sua política externa tradicional e sua busca pela construção de um multilateralismo efetivo.

Inicialmente, na explicação do mecanismo causal, enfatiza-se que o processo de crescimento econômico acentuado, fora da Europa e das demais economias do G7, tem colocado pressão crescente sobre a capacidade de atuação externa da UE. O’Neill (2001) chamou a atenção para esse processo em seu artigo clássico sobre os BRICs, apontando que o 
PIB dessas economias deveria superar o do G7 a partir de $2050^{36}$. Porém, não apenas em termos econômicos esses países desafiam o centro do capitalismo no século XXI, mas crescentemente também em recursos populacionais, diplomáticos e geopolíticos.

Portanto, a implicação observável desse aspecto do mecanismo causal é a resposta europeia ao crescimento em poder econômico de potências emergentes, pela busca de acordos preferenciais de comércio com esses países, e/ou a assinatura de parcerias estratégicas com eles - a fim de contrabalançar a atuação de atores rivais que igualmente buscam acordos favoráveis com países em desenvolvimento. Igualmente, agindo assim a UE busca "nivelar o campo de jogo" para suas multinacionais

Evidência que desconfirma essa parte do mecanismo causal seria a ausência de ação da UE no sentido de garantir acordos privilegiados de comércio com economias emergentes, e a continuidade de cooperação no nível regional em que essas economias desempenham papel central (por exemplo um acordo regional com MERCOSUL no caso do Brasil, ou com ASEAN no caso de Cingapura).

No que se refere à segunda parte do mecanismo causal, a UE busca responder à ascensão de potências econômicas em regiões distantes, fortalecendo a cooperação com esses países no contexto de organizações regionais - inclusive por meio da assinatura de tratados de livre comércio. Portanto, esse cenário complementa as ações da UE a fim de buscar acordos vantajosos na arena bilateral, e segue a atuação mais tradicional europeia no quadro do interregionalismo. Uma implicação observável dessa parte do mecanismo causal são posicionamentos dos chefes da diplomacia da UE a fim de aprofundar a cooperação europeia com regiões terceiras; iniciação ou retomada de negociações inter-regionais; defesa do interregionalismo em documentos chave do aparato institucional europeu (área de comércio).

\footnotetext{
${ }^{36}$ Roberts et al. (2018, p.1) apontam que essa data foi logo adiantada para a década de 2020.
} 
Evidência que desconfirma essa parte do mecanismo causal seria a não atuação europeia no sentido de avançar acordos regionais de comércio; a não-priorização do nível inter-regional nos principais documentos que guiam a ação diplomática europeia, ou as negociações internacionais de comércio; e por fim, a retirada da UE das negociações com regiões terceiras e a não atualização dos mandatos para negociação comercial no nível inter-regional.

Por fim, a terceira parte do mecanismo causal refere-se à demanda crescente sobre as instituições europeias, no que se refere à preparação para novas negociações de comércio, as negociações de fato, bem como a atualização de acordos existentes. Assim, face ao crescimento rápido de acordos preferenciais de comércio (APCs), aumenta-se a pressão sobre a capacidade da DG Comércio de lidar com a nova dinâmica (ADRIANSEN, 2014). Porém, no contexto pósLisboa, a UE também tem objetivado uma maior coordenação de suas instituições a fim de responder adequadamente a esse desafio externo.

Assim, uma implicação observável dessa parte do mecanismo causal é que os oficiais da UE não expressem uma preferência ideacional clara pelo inter-regionalismo ou pelo bilateralismo na arena de comércio. Evidência contrária a essa parte do mecanismo causal seria a priorização de acordos inter-regionais de comércio, em consonância com o histórico da UE, bem como no que se refere aos objetivos normativos de política externa do bloco. 


\begin{tabular}{|c|c|c|}
\hline Mecanismo causal & Implicação observável & Evidência contrária \\
\hline Agenda de atores da UE & $\begin{array}{l}\text { Necessidade de novos } \\
\text { acordos preferenciais de } \\
\text { comércio }\end{array}$ & - \\
\hline $\begin{array}{l}\text { UE busca novos APCs } \\
\text { com potências } \\
\text { emergentes }\end{array}$ & $\begin{array}{l}\text { Resposta de atores rivais } \\
\text { à estratégia europeia }\end{array}$ & $\begin{array}{l}\text { Atores rivais mostram-se } \\
\text { indiferentes à iniciativa } \\
\text { europeia }\end{array}$ \\
\hline $\begin{array}{l}\text { UE continua a atuar a fim } \\
\text { de assinar acordos } \\
\text { regionais de livre- } \\
\text { comércio }\end{array}$ & $\begin{array}{l}\text { Atualização de mandatos } \\
\text { de negociação no nível } \\
\text { inter-regional }\end{array}$ & $\begin{array}{l}\text { UE retira-se de } \\
\text { negociações inter- } \\
\text { regionais, e não atualiza } \\
\text { mandatos }\end{array}$ \\
\hline $\begin{array}{l}\text { Quantidade crescente de } \\
\text { acordos e negociações }\end{array}$ & $\begin{array}{l}\text { Oficiais dedicam esforço } \\
\text { para ambas arenas, inter- } \\
\text { regional e bilateral }\end{array}$ & $\begin{array}{l}\text { Oficiais da UE dedicam } \\
\text { esforços prioritariamente } \\
\text { para a arena inter- } \\
\text { regional }\end{array}$ \\
\hline $\begin{array}{l}\text { UE ajusta seu desenho de } \\
\text { política comercial }\end{array}$ & $\begin{array}{l}\text { Acordos bilaterais e } \\
\text { regionais }\end{array}$ & $\begin{array}{l}\text { Arena inter-regional é } \\
\text { manifestamente } \\
\text { considerada prioridade, } \\
\text { em consonância com } \\
\text { princípios de pol. ext. }\end{array}$ \\
\hline
\end{tabular}

Fonte: Dados compilados pelo autor, a partir de adaptação da análise de Meissner (2016)

\section{Hipótese}

A Comissão observa, por meio das representações diplomáticas da UE no exterior, a atuação de atores rivais em regiões terceiras, buscando reduzir a influência desses competidores em mercados de interesse para empresas europeias. Assim, conforme enfatizamos mais acima, a UE tenta antecipar-se ao movimento de potências econômicas (China, EUA, Japão), e firmar 
acordos regionais a fim de garantir acesso a recursos e/ou nivelar o campo de jogo para multinacionais ${ }^{37}$.

No entanto, levando em consideração o objetivo europeu de avançar um multilateralismo efetivo ${ }^{38}$, a UE também observa e atua na arena multilateral por meio de sua representação nas principais organizações econômicas de governança global. Nessa arena, o discurso e ação da UE refletem o histórico de atuação do bloco desde os primórdios da integração europeia: defesa dos princípios liberais na organização da atividade econômica; estabilidade internacional e o avanço da integração econômica em regiões terceiras.

À medida que avança o processo de difusão de poder na arena internacional, bem como o deslocamento do eixo de gravidade econômica para a Ásia, potências emergentes passam a questionar as bases em que se assenta a governança econômica global. Esse processo tem sido observado a partir dos primeiros anos do século XXI, com a re-emergência da China e a formulação de novos grupos de países do SUL (IBSA) e o impasse na rodada Doha a partir de 2003. O processo tornou-se particularmente agudo, porém, com a crise econômica desencadeada em 2008 nos EUA e que rapidamente colocou em questão o modelo neoliberal.

Assim, à medida que a competição por mercados e recursos entre a UE e atores rivais passa a ser mais aguda em função do quadro de crise econômica, bem como por desgaste

\footnotetext{
${ }^{37}$ O papel da UE como "market power Europe", bem como a competitividade das companhias europeias dentro das cadeias globais de valor são os elementos cruciais da estratégia de comércio atual: as companhias europeias devem crescentemente produzir produtos de alto-valor e bens intermediários (incluindo serviços) para os mercados global e interno por meio de matérias-primas e componentes importados. Essa é a base para o crescimento de exportações no setor de serviços e de manufatura, e portanto cria o potencial para superávits comerciais de longo prazo em relação ao resto do mundo. Assim, a UE define a competividade das companhias europeias como a chave para o sucesso, o que requer uma combinação de políticas domésticas e externas. (GRUMILLER ET AL., 2016, p. 6)

${ }^{38}$ Embora a literatura recente tenha enfatizado que as dificuldades no âmbito multilateral tenham impulsionado a formação de PTAs, também é possível que uma causalidade reversa esteja operando no processo. Isto é, a assinatura crescente de acordos bilaterais pode ser responsável pela falta de progresso no âmbito multilateral (HOEKMAN \& MAVROIDIS, 2015, p. 320)
} 
institucional a nível internacional, e pelo questionamento da ordem econômica internacional a UE adapta seu posicionamento na arena externa. Mais especificamente na arena comercial, a UE buscará estreitar relações com atores rivais, o que nos permite formular a seguinte hipótese:

3) Quanto menor a relevância da UE na arena multilateral, mais ela buscará relações próximas com atores rivais na arena bilateral.

Como se sabe, a UE tem testemunhado uma diminuição de sua relevância vis-à-vis países emergentes (em termos da percepção desses países), conforme ficou mais explícito no caso da relação bilateral UE-Índia. Em outras palavras, o bloco europeu tem tido dificuldade crescente de fazer avançar aquilo que considera como "normal" na vida internacional, ou de fazer expressar seu poder normativo, bem como de atuar estrategicamente em regiões distantes (KAVALSKI, 2016).

A primeira parte do mecanismo causal refere-se à efetiva formulação, a nível europeu, de uma estratégia de política exterior e de segurança, capaz de fazer face a desafios emergentes na arena internacional. Assim, por meio dos recursos do SEAE, e da ação do AR/VP da Comissão, elaboram-se avaliações a respeito da evolução do cenário externo e produzem-se documentos que sistematizam essas conclusões $^{39}$, a exemplo da: EES de 2003 (revisada em 2008); a Estratégia Global de 2016; White Paper on the Future of Europe, entre outros. A implicação observável dessa parte do mecanismo causal portanto reside na elaboração, por parte da UE, de documentos coerentes e capazes de guiar a ação dos diferentes atores de política externa europeia.

\footnotetext{
${ }^{39}$ Dentro do processo que facilitou o debate sobre a estratégia, numerosas discussões, seminários e workshops ocorreram entre Outubro de 2015 e Abril de 2016 na Europa e mais de 50 papers escritos por acadêmicos e especialistas de todo o mundo alimentaram o processo de escrita. (EUISS, 2016) (SUS, 2017).
} 
Evidência desconfirmando essa parte do mecanismo causal seria a ausência dessa articulação estratégica em documentos-chave da diplomacia europeia, bem como da ação da UE na esfera do comércio internacional - produzidos pela DG Comércio sob coordenação do Comissário para comércio exterior.

A segunda parte do mecanismo causal da hipótese 3 refere-se à incapacidade, por parte da UE, de reagir à ascensão de novas potências e desafios na arena internacional, de forma estratégica. Assim, face ao posicionamento desses atores de forma contrária aos objetivos europeus, a UE mostra-se incapaz de mobilizar recursos de forma concertada a fim de atingir objetivos previamente estabelecidos nas esferas econômica, de segurança e societal na arena internacional. Isso se manifesta principalmente por meio do aparato diplomático europeu, porém também no que se refere ao aparato institucional de comércio internacional - suposto a atender objetivos econômicos de política externa.

Evidência que desconfirma essa parte do mecanismo causal seria o sucesso europeu em fazer avançar um multilateralismo efetivo, nas diferentes dimensões da vida internacional: econômica, de segurança, bem como de meio-ambiente. Igualmente, nesse cenário a UE é capaz de articular-se com seus principais parceiros diplomáticos e fazer face à ascensão de novas coalizões de países emergentes.

A terceira parte do mecanismo causal refere-se ao posicionamento europeu em resposta a crises e impasses na arena multilateral do comércio, no que se refere a maior liberalização de mercados de países desenvolvidos. Desta forma, face à dificuldade em fazer avançar seus objetivos junto a países emergentes, a UE passa a priorizar a conclusão de acordos que incluem parceiros econômicos mais tradicionais. Portanto, evidência confirmando essa parte do mecanismo causal seriam avaliações da Comissão da necessidade de novos acordos com potências econômicas, bem como a requisição da Comissão ao Conselho de um mandato para 
iniciar tais negociações. Igualmente, em seus posicionamentos oficiais, o chefe da diplomacia europeia deveria enfatizar a importância de acesso a mercados de países desenvolvidos, bem como a desregulamentação de setores importantes além das fronteiras.

Evidência que desconfirma essa parte do mecanismo causal seria a continuidade do posicionamento europeu de buscar acordos de livre comércio com potências emergentes, bem como a indiferença face a ofertas atrativas de acordos por parte de atores rivais (EUA, Japão).

Tabela 6: Mecanismo causal da Hipótese 3

\begin{tabular}{|c|c|c|}
\hline Mecanismo causal & Implicação observável & Evidência contrária \\
\hline $\begin{array}{l}\text { UE compete com atores } \\
\text { rivais }\end{array}$ & $\begin{array}{l}\text { Grandes potências podem } \\
\text { constranger a atuação } \\
\text { econômica da UE }\end{array}$ & - \\
\hline $\begin{array}{l}\text { Elaboração de uma } \\
\text { estratégia europeia } \\
\text { coerente }\end{array}$ & $\begin{array}{l}\text { Produção de documentos } \\
\text { condensando essa } \\
\text { estratégia }\end{array}$ & $\begin{array}{l}\text { Ausência de documentos/ } \\
\text { Documentos incoerentes } \\
\text { ou desatualizados }\end{array}$ \\
\hline $\begin{array}{l}\text { UE incapaz de responder } \\
\text { a desafios externos }\end{array}$ & $\begin{array}{l}\text { Aparato diplomático } \\
\text { fragmentado }\end{array}$ & $\begin{array}{l}\text { UE atuando de forma } \\
\text { bem-sucedida a fim de } \\
\text { avançar multilateralismo } \\
\text { efetivo }\end{array}$ \\
\hline $\begin{array}{l}\text { UE incapaz de avançar } \\
\text { seus interesses na arena } \\
\text { multilateral de comércio }\end{array}$ & $\begin{array}{l}\text { Comissão busca novos } \\
\text { acordos com países } \\
\text { desenvolvidos }\end{array}$ & $\begin{array}{l}\text { UE mostra-se indiferente } \\
\text { à possibilidade de } \\
\text { acordos com atores rivais }\end{array}$ \\
\hline $\begin{array}{l}\text { UE ajusta seu desenho de } \\
\text { política comercial }\end{array}$ & $\begin{array}{l}\text { UE busca relações mais } \\
\text { próximas com atores- } \\
\text { chave na arena bilateral }\end{array}$ & $\begin{array}{l}\text { UE mantém ações na } \\
\text { arena multilateral e inter- } \\
\text { regional }\end{array}$ \\
\hline
\end{tabular}




\section{Hipótese}

$\mathrm{Na}$ esfera comercial a UE presta atenção especial ao aspecto da coesão de regiões terceiras (SODERBAUM, 2015). Embora sejam diversos os indicadores de coesão, e o próprio conceito de coesão seja sujeito a debate, empiricamente a Comissão monitora dinâmicas e processos regionais nas diversas partes do mundo. A Comissão monitora esses atores e dinâmicas por meio da participação em organizações internacionais, cúpulas dos principais clubes econômicos globais, bem como por meio de suas representações diplomáticas.

Embora no campo de segurança internacional a política externa europeia ainda dependa da coordenação das posições individuais dos estados membros no nível intergovernamental, em assuntos de política comercial já houve delegação de autoridade para a Comissão, que é a única instituição autorizada a negociar em nome da UE. Assim, por meio da coordenação com o SEAE, e por meio das representações diplomáticas da UE em países terceiros, a Comissão avalia a atuação de grupos e coalizões de parceiros e países emergentes. Isso não apenas nas arenas inter-regional e bilateral, mas também ao longo de setores (compras governamentais, propriedade intelectual, serviços, etc).

A avaliação de oportunidades na esfera comercial, no entanto, não está separada de considerações de natureza geopolítica, e assim a UE pode entender que um acordo interregional serviria a interesses europeus mais amplos. Isto é, o acordo poderia trazer maior estabilidade regional, ou equilibrar a ação diplomática de outros atores (por exemplo EUA, China). Portanto a UE pode manter um desenho de negociação inter-regional, mesmo se a região homóloga não apresenta as características ideais para um acordo dessa natureza. 


\section{4) A fim de atingir objetivos de natureza política, a UE terá maior probabilidade de manter um desenho de negociação inter-regional quando se trata de uma região não- coesa}

Ao expor mecanismo causal da hipótese 4, inicialmente enfatiza-se que a UE busca liberalizar o máximo de setores com o maior número possível de países. Assim, a Comissão monitora a ação de atores rivais, e reage negociando acordos nas arenas regional e bilateral. Quando há a impossibilidade de se chegar a um acordo na arena inter-regional, a UE pode chegar à avaliação de que um acordo bilateral pode ser a via mais adequada para a liberalização em um setor específico. Porém, a UE pode optar por manter o formato inter-regional de negociações

Assim, uma implicação observável dessa parte do mecanismo causal refere-se a declarações de oficiais da UE, sobre a preferência do bloco por um acordo inter-regional. Igualmente, espera-se que a Comissão publique notas salientando as vantagens de um acordo nessa arena. Evidência que desconfirma essa parte do mecanismo causal seria a ausência de posicionamento da UE nesse sentido.

A segunda parte do mecanismo causal refere-se à decisão da UE de manter um desenho de negociação inter-regional, após avaliar que a região homóloga não é coesa. Assim, a UE avalia os objetivos estritos na arena comercial, em sua interrelação com objetivos europeus mais amplos, e de outra natureza (e.g. geopolíticos) na região - podendo chegar à conclusão de que o acordo serviria a aumentar o poder europeu e a competitividade da UE (MEISSNER, 2017), ou à estabilidade de uma região de alto valor estratégico.

Portanto, uma implicação observável do mecanismo causal nessa parte seriam documentos da fase de pré-negociação que enfatizam a motivação política para a conclusão do acordo, bem como a inclusão de cláusulas relativas aos direitos humanos, à democracia, ao 
meio-ambiente no mandato de negociação. Evidência que desconfirma essa parte do mecanismo causal seria a ausência de preocupações de tal ordem em pronunciamentos de diplomatas e negociadores europeus, bem como a ausência de exigência de inclusão de normas de proteção de direitos fundamentais no acordo.

A terceira parte do mecanismo causal refere-se à ação externa da UE a fim de viabilizar o início de negociações para o acordo inter-regional. Portanto, a UE atua no âmbito de organismos internacionais, bem como junto a países parceiros, a fim de que as negociações passem a ocupar espaço de relevo na agenda do comércio internacional. Assim, tanto os diplomatas da UE, como os funcionários europeus que desempenham funções relacionadas à representação externa do bloco, externam opiniões positivas sobre as consequências do acordo - tanto em manifestações oficiais, quanto no âmbito de negociações não abertas ao público.

Portanto, uma implicação observável dessa parte do mecanismo causal refere-se à presença de posicionamentos e argumentos europeus em documentos oficiais, press releases, position papers, bem como em declarações de oficiais europeus à imprensa. Por outro lado, evidência que desconfirma esse aspecto do mecanismo causal seria o não posicionamento público europeu a favor de um acordo inter-regional, ou a tentativa de avançar a liberalização no setor almejado por meio de outra arena (bilateral) 
Tabela 7: Mecanismo causal da Hipótese 4

\begin{tabular}{|l|l|l|}
\hline Mecanismo causal & Implicação observável & Evidência contrária \\
\hline $\begin{array}{c}\text { Coesão da região } \\
\text { homóloga (ou coalizão) }\end{array}$ & \multicolumn{1}{|c|}{ Índice de coesão } \\
\hline $\begin{array}{l}\text { UE monitora grupos e } \\
\text { coalizões de países }\end{array}$ & $\begin{array}{l}\text { Ação diplomática } \\
\text { europeia em países e } \\
\text { regiões terceiras }\end{array}$ & $\begin{array}{l}\text { UE não presta atenção } \\
\text { especial a arena inter- } \\
\text { regional }\end{array}$ \\
\hline $\begin{array}{l}\text { UE avalia que um acordo } \\
\text { inter-regional é a melhor } \\
\text { opção }\end{array}$ & $\begin{array}{l}\text { Documentos oficiais, } \\
\text { notas à imprensa e } \\
\text { memorandos. }\end{array}$ & $\begin{array}{l}\text { Não posicionamento } \\
\text { europeu a favor de um } \\
\text { acordo nessa arena }\end{array}$ \\
\hline $\begin{array}{l}\text { UE busca viabilizar o } \\
\text { início de negociações } \\
\text { para o acordo }\end{array}$ & $\begin{array}{l}\text { Atuação da UE junto a } \\
\text { países parceiros, e outras } \\
\text { organizações } \\
\text { internacionais }\end{array}$ & $\begin{array}{l}\text { Continuidade da tentativa } \\
\text { de fazer avançar a } \\
\text { liberalização em outras } \\
\text { arenas }\end{array}$ \\
\hline $\begin{array}{l}\text { UE ajusta seu desenho de } \\
\text { política comercial }\end{array}$ & $\begin{array}{l}\text { Acordo inter-regional } \\
\text { quando a região não é } \\
\text { coesa }\end{array}$ & $\begin{array}{l}\text { Ausência de atuação com } \\
\text { fins a obter um acordo } \\
\text { inter-regional }\end{array}$ \\
\hline
\end{tabular}

Fonte: Adaptado a partir do modelo utilizado por Meissner (2016) 


\section{CAPÍTULO 3}

\subsection{Metodologia}

Este capítulo apresenta, inicialmente, a operacionalização da variável dependente e da operacionalização das variáveis independentes, e do desenho de pesquisa e das fontes de dados utilizadas na análise empírica dos $\operatorname{casos}^{40}$. A segunda parte deste capítulo é dedicada aos estudos de caso que compõem a parte de análise empírica da tese. Trata-se de analisar quatro casos: os dois primeiros de negociação da União Europeia com os BRICS e com o GCC (Conselho de Cooperação dos Países do Golfo) por se tratar de duas negociações relevantes, com atores com perfis e interesses econômicos diversos. Isso nos permite comparar dois casos distintos, para compreender como a UE se adaptou e conduziu os dois processos. E os dois estudos de caso seguintes referem-se ao TTIP (Parceria Transatlântica de Investimentos e Comércio) e o Mercosul (a partir de 2016), por se tratarem de dois processos de negociação recentes que servem de contraponto para a análise a União Europeia. Por fim, três casos secundários adicionais (Canadá, Japão e Coréia do Sul) integram a seção final do capítulo.

40 Os testes hoop estabelecem os critérios necessários para uma explicação baseada na lógica de condições necessárias, e são mais demandantes do que testes straw-in-the-wind. Passar um teste hoop não necessariamente confirma uma hipótese, mas falhar um teste hoop praticamente elimina aquela hipótese (Collier, 2011)

Os testes smoking gun estabelecem critérios suficientes mas não necessários para uma explicação baseada na lógica de condições suficientes, e são em certa medida mais demandantes que testes hoop e muito mais demandantes que testes straw-in-the-wind. Passar um teste smoking-gun portanto confirma fortemente uma hipótese, mas falhar um teste desse tipo não rejeita uma hipótese (idem) (MEISSNER, 2016) 


\subsubsection{Operacionalização da variável dependente}

Tabela 8 Operacionalização da variável dependente

\begin{tabular}{|c|c|c|c|}
\hline & Abrangente & Seletivo & Efetivo \\
\hline Multilateral & - & - & Multilateralismo efetivo \\
\hline Interregional & $\begin{array}{c}\text { Interregionalismo } \\
\text { abrangente }\end{array}$ & $\begin{array}{c}\text { Interregionalismo } \\
\text { Seletivo }\end{array}$ & - \\
\hline Bilateral & $\begin{array}{l}\text { Bilateralismo } \\
\text { Abrangente }\end{array}$ & $\begin{array}{l}\text { Bilateralismo } \\
\text { Seletivo }\end{array}$ & - \\
\hline
\end{tabular}

Fonte: Elaboração própria a partir do quadro utilizado na análise de Meissner (2016)

Em adição aos trabalhos de McCrossan (2014), Meissner (2016), Sahakyan (2015) e Schade (2016) esta tese também aborda o posicionamento da UE em relação a grupos de países, portanto não estando restrito às arenas inter-regional ou bilateral. Desta forma, o posicionamento em relação a coalizões na arena comercial é entendido dentro do objetivo mais amplo da UE de promover um multilateralismo efetivo. 


\subsubsection{Operacionalização das variáveis independentes}

Coerência entre política comercial e política externa

Conforme enfatizado na seção inicial deste capítulo, a UE compete com atores rivais, que na perspectiva do Realismo Comercial são China, Japão e EUA, com base no tamanho de seu PIB (produto interno bruto). Um dos instrumentos que a UE pode utilizar para a persecução de objetivos econômicos externos é a assinatura de um APC (acordo preferencial de comércio) com um país ou região terceira. Assim, existe uma interrelação entre a política comercial europeia e a política externa do bloco, cuja coordenação tem sido mais intensa após a entrada em vigor do tratado de Lisboa em 2009.

Assim, a primeira etapa do mecanismo causal é o monitoramento, pela UE, da formação de novos grupamentos de potências emergentes. As etapas seguintes da cadeia causal são as discussões no Conselho sobre a necessidade de adotar uma política para esses grupamentos de países, seguidas pela busca de novos acordos na arena bilateral. As duas primeiras etapas não são claramente independentes uma da outra, portanto tem um baixo grau de singularidade. Se a hipótese 1 é verdadeira, podemos esperar com relativa certeza que a UE monitora a formação de novos grupos de potências emergentes, bem como sua atuação combinada. Por outro lado, se esse monitoramento não se dá no quadro de uma estratégia clara e bem articulada da UE para a arena internacional, a UE tenderá a abordar estrategicamente parceiros no nível bilateral. Assim, a Hipótese 1 passa um teste hoop se encontramos as peças de evidência um e três, e um teste straw-in-the-wind se encontramos evidência de número dois. 
Tabela 9: Evidência empírica esperada para a Hipótese 1

\begin{tabular}{|c|c|c|c|}
\hline $\begin{array}{l}\text { Peça de } \\
\text { evidência }\end{array}$ & Mecanismo causal & Certeza & Singularidade \\
\hline $\begin{array}{c}\text { Variável } \\
\text { independente }\end{array}$ & $\begin{array}{l}\text { Nexo entre política } \\
\text { comercial e política } \\
\text { externa }\end{array}$ & & \\
\hline Um & $\begin{array}{l}\text { UE monitora a } \\
\text { formação de novos } \\
\text { grupamentos de } \\
\text { potências } \\
\text { emergentes }\end{array}$ & Alta certeza & Baixa singularidade \\
\hline Dois & $\begin{array}{l}\text { Discussões no } \\
\text { Conselho sobre a } \\
\text { necessidade de } \\
\text { adotar política p/ } \\
\text { esses grupos }\end{array}$ & Baixa certeza & Baixa singularidade \\
\hline Três & $\begin{array}{l}\text { UE enuncia a busca } \\
\text { de novos acordos na } \\
\text { arena bilateral }\end{array}$ & Alta certeza & Baixa singularidade \\
\hline $\begin{array}{c}\text { Variável } \\
\text { dependente }\end{array}$ & $\begin{array}{l}\text { UE adapta o } \\
\text { desenho de sua PEC }\end{array}$ & & \\
\hline
\end{tabular}

Fonte: Dados organizados pelo Autor, a partir de adaptação da análise de Meissner (2016). 
Preferências das instituições da UE

A UE tradicionalmente privilegia a esfera inter-regional para negociações de novos acordos de comércio, em função do histórico da formação e evolução da organização regional. Porém, a partir de meados dos anos 2000 verificou-se uma expansão significativa de novos acordos bilaterais e parcerias estratégicas, com base na estratégia "Global Europe" de 2006. Assim, seria possível afirmar que esse movimento representa um distanciamento da política externa tradicional da UE, que deveria privilegiar a promoção dos valores e experiência europeias para regiões terceiras.

No entanto, a partir da tese do Realismo Comercial (MEISSNER, 2016), é possível afirmar que na arena do comércio os atores institucionais da UE não demonstram uma preferência clara pelo inter-regionalismo ou pela esfera bilateral. Assim, na primeira etapa do mecanismo causal, a UE busca novos acordos com potências emergentes, ao passo que continua a atuar a fim de assinar acordos regionais de livre comércio. E, por fim, essa quantidade crescente de novos acordos almejados e negociações pressiona a capacidade administrativa da UE. Os dois primeiros passos do mecanismo causal são dependentes entre si, porém são claramente distintos do terceiro passo, que tem alta singularidade. Portanto, tomando em conjunto essas peças de evidência, a hipótese 2 passa um teste straw-in-the-wind se encontramos a peça um; um teste hoop se encontramos a peça dois; e também um teste hoop se encontramos a peça três. 
Tabela 10: Evidência empírica esperada para a Hipótese 2

\begin{tabular}{|c|c|c|c|}
\hline $\begin{array}{l}\text { Peça de } \\
\text { evidência }\end{array}$ & Mecanismo causal & Certeza & Singularidade \\
\hline $\begin{array}{c}\text { Variável } \\
\text { independente }\end{array}$ & $\begin{array}{l}\text { Agenda dos atores da } \\
\text { UE }\end{array}$ & & \\
\hline Um & $\begin{array}{l}\text { UE busca novos } \\
\text { APCs com potências } \\
\text { emergentes }\end{array}$ & Baixa certeza & Baixa singularidade \\
\hline Dois & $\begin{array}{l}\text { UE mantém objetivo } \\
\text { de assinar acordos } \\
\text { regionais de livre- } \\
\text { comércio }\end{array}$ & Alta certeza & Baixa singularidade \\
\hline Três & $\begin{array}{l}\text { Quantidade crescente } \\
\text { de acordos e } \\
\text { negociações }\end{array}$ & Alta certeza & Alta singularidade \\
\hline $\begin{array}{l}\text { Variável } \\
\text { dependente }\end{array}$ & $\begin{array}{l}\text { UE adapta o desenho } \\
\text { de sua } \\
\text { comercial }\end{array}$ & & \\
\hline
\end{tabular}

Fonte: Tabela adaptada a partir do modelo utilizado por Meissner (2016) 


\section{Atores rivais}

A competição com atores rivais não é restrita ao âmbito da região homóloga, mas também se dá na esfera multilateral, apesar de o Realismo Comercial não ter analisado esse domínio das relações comerciais internacionais. Diferentemente das esferas bilateral e regional, uma característica que se sobressai na esfera multilateral é a atuação da UE junto a grupos de economias avançadas, e a atuação a fim de liberalizar setores específicos, ou promover normas e valores (e.g. multilateralismo efetivo). Uma diferença adicional em relação ao conceito de atores rivais formulado por Meissner (2016) é que a UE também compete com outros atores além de China, Japão e EUA - isto é, países em desenvolvimento.

Desta forma, a UE inicialmente elabora uma estratégia de ação externa delineando as principais prioridades para as diferentes arenas, pautadas por princípios claras, e articuladas com os instrumentos para a persecução desses objetivos. Em seguida, a UE enfrenta uma ação mais assertiva de potências emergentes na arena do comércio internacional, levando à terceira etapa do mecanismo causal: a busca de novos acordos com grandes atores do regime de comércio (e.g. EUA, Canadá, Japão). A primeira etapa do mecanismo causal é claramente distinta da segunda, porém evidência de elaboração de uma estratégia europeia não fornece apoio à hipótese. Igualmente, se a hipótese é verdadeira, podemos ter certeza de encontrar evidências da incapacidade europeia de fazer face à ação concertada de potências emergentes, bem como da decisão da UE de buscar acordos com países mais tradicionais. Assim, a hipótese 3 passa um teste smoking-gun se encontramos as peças de evidência de números um e três; um teste hoop se encontramos a evidência de número dois. 
Tabela 11: Evidência empírica esperada para a Hipótese 3

\begin{tabular}{|c|c|c|c|}
\hline $\begin{array}{l}\text { Peça de } \\
\text { evidência }\end{array}$ & Mecanismo causal & Certeza & Singularidade \\
\hline $\begin{array}{c}\text { Variável } \\
\text { independente }\end{array}$ & $\begin{array}{l}\text { Competição com } \\
\text { atores rivais na } \\
\text { arena multilateral }\end{array}$ & & \\
\hline Um & $\begin{array}{l}\text { Elaboração de uma } \\
\text { estratégia europeia } \\
\text { coerente }\end{array}$ & Baixa certeza & Alta singularidade \\
\hline Dois & $\begin{array}{c}\text { UE incapaz de } \\
\text { responder a desafios } \\
\text { externos }\end{array}$ & Alta certeza & Baixa singularidade \\
\hline Três & $\begin{array}{c}\text { UE busca acordos } \\
\text { com parceiros mais } \\
\text { tradicionais }\end{array}$ & Baixa certeza & Alta singularidade \\
\hline $\begin{array}{c}\text { Variável } \\
\text { dependente }\end{array}$ & $\begin{array}{c}\text { UE ajusta o desenho } \\
\text { sua PEC }\end{array}$ & & \\
\hline
\end{tabular}

Fonte: Adaptado a partir de Meissner (2016) 


\section{Coesão}

Assumindo que um alto grau de coesão leva a força no cenário internacional, isso influencia o desenho da PEC em relação a regiões terceiras (MEISSNER, 2016, p. 105). Porém, outros fatores, tais como o contexto dessas regiões, ou a motivação da UE para escolher um desenho de política comercial, também influenciam a opção da UE pela arena inter-regional ou bilateral. De uma perspectiva realista, a expectativa é que a UE buscasse acordos bilaterais com países de organizações regionais pouco coesas.

A primeira etapa do mecanismo causal refere-se ao monitoramento, pela UE, de grupos e coalizões de países que podem ser do interesse econômico europeu. Em seguida, a UE avalia qual formato de acordo, inter-regional, ou bilateral, ou mesmo a ausência de acordo seria o mais adequado para seus objetivos, e por fim a UE busca viabilizar o acordo. Desta forma, evidência que dê suporte à segunda etapa do mecanismo causal, apoia a hipótese. Portanto, analisando esse conjunto de evidências podemos afirmar que a hipótese 4 passa um teste smoking-gun fraco se encontramos a peça de evidência número um; um teste hoop se encontramos a peça de evidência número dois, e um teste smoking-gun se encontramos a evidência de número três. 
Tabela 12: Evidência empírica esperada para a Hipótese 4

\begin{tabular}{|c|l|l|l|}
\hline $\begin{array}{c}\text { Peça de } \\
\text { evidência } \\
\begin{array}{c}\text { Variável } \\
\text { independente }\end{array}\end{array}$ & \multicolumn{1}{|c|}{ Mecanismo causal } & Certeza & Singularidade \\
\hline Um & $\begin{array}{l}\text { UE monitora grupos } \\
\text { e coalizões de países }\end{array}$ & Baixa certeza & Média singularidade \\
\hline Dois & $\begin{array}{l}\text { UE avalia que um } \\
\text { acordo inter-regional } \\
\text { é a melhor opção }\end{array}$ & Alta certeza & Baixa singularidade \\
\hline Três & $\begin{array}{l}\text { UE busca viabilizar } \\
\text { o acordo }\end{array}$ & Baixa certeza & Alta singularidade \\
\hline $\begin{array}{l}\text { Variável } \\
\text { dependente }\end{array}$ & $\begin{array}{l}\text { UE ajusta o desenho } \\
\text { de sua PEC }\end{array}$ & & \\
\hline
\end{tabular}

Fonte: Adaptado a partir do modelo utilizado por Meissner (2016) 


\subsubsection{Desenho de pesquisa}

Poucos estudos combinam variáveis domésticas e sistêmicas na análise da política comercial europeia. Assim, destacam-se os trabalhos de McCrossan (2014), que se centra na análise da política inter-regional da UE, levando em consideração dinâmicas domésticas a regiões terceiras, bem como processos internos à UE. Van Loon $(2013,2018)$ também empreende uma análise do inter-regionalismo do bloco, utilizando elementos do neo-realismo, construtivismo e institucionalismo, mas não leva em consideração a variação do resultado do desenho de política comercial da UE. Assim, este trabalho soma-se à contribuição recente de Meissner (2016), ao analisar como variáveis intra e extra-regionais influenciam o desenho de política comercial da UE.

São adotados elementos de contribuições recentes sobre a coerência entre política comercial e política externa da UE (BOSSUYT ET. AL, 2018; SCHADE, 2016; RENARD, 2016), e do quadro conceitual de Meissner (2016; 2017) sobre Realismo Comercial e interregionalismo como meio para atingir objetivos geopolíticos da UE. Desta forma, analisam-se a interação entre regiões terceiras e coalizões com a UE, a interação entre atores rivais e essas regiões, e dinâmicas internas à UE, com foco nos aspectos de estratégia de ação externa. No que se refere à perspectiva da UE como ator unitário, reforça-se o enunciado na introdução da tese, de que o Realismo Comercial confirmou essa característica do bloco, levando em consideração a ação da Comissão na elaboração do mandato de negociação e nas rodadas de negociação.

No que diz respeito à política externa dos Estados-Membros, adota-se a perspectiva de Schade (2016), de considerar essas unidades no contexto do Conselho da UE. Por limitações de espaço e tempo, a atuação dos grupos de interesse sobre a política comercial da UE não foi analisada, e também porque no contexto de regiões e grupos que não ocupam um espaço bem 
estruturado no quadro de relações exteriores do bloco, não há a atuação de grupos de interesse a fim de influenciar resultados da PEC.

\subsubsection{Fontes de dados}

A fim de se obter os mandatos de negociação da UE, bem como informações relevantes a respeito das negociações de comércio do bloco, foram utilizados os sites da DG Comércio (DG Trade) da Comissão Europeia e da base de dados DORIE (Documentation et Recherche sur les questions Institutionnelles Européennes). Esses sites disponibilizam informações detalhadas acerca das negociações concluídas e em curso, bem como relatórios atualizados sobre diferentes aspectos dos tratados, disponibilização de documentos que eram previamente confidenciais - além de manifestações de líderes da diplomacia europeia.

Para acessar dados detalhados sobre as negociações comerciais bem-sucedidas da UE, foram consultados os dados disponíveis na base de dados DESTA (Design of Trade Agreements, disponível em http://www.designoftradeagreements.org), projeto internacional que compila dados de negociações comerciais. No que se refere às negociações em curso e fracassadas, consultaram-se o site da Comissão Europeia relativo a política comercial, bem como relatórios de organizações internacionais, think-tanks e artigos acadêmicos já publicados sobre o tema.

Assim, esta pesquisa baseou-se essencialmente em análise empírica qualitativa, a partir da análise de material primário, incluindo dados de documentos oficiais e artigos de imprensa que levam em consideração as negociações da UE nas esferas inter-regional e bilateral. A análise levou em consideração a publicação e adoção de estratégias da UE para a arena do comércio internacional: Global Europe de 2006; Trade growth and world affairs, de 2010; e 
Trade for all de 2015. Ademais, essa análise foi complementada a partir do estudo de pesquisas empíricas já realizadas sobre os casos.

Uma fonte adicional de dados consultada sobre as negociações de comércio da UE consiste na base de dados do Wikileaks ${ }^{41}$ (cablegate). O site reúne mais de 250.000 cabos diplomáticos dos EUA no período de 2003-2010, disponíveis on-line, e que cobrem muitas vezes a avaliação de embaixadas americanas sobre a competição com a UE na arena comercial, ou o posicionamento de países parceiros da UE em negociações em curso ou futuras. Ademais, a base de dados muitas vezes traz o posicionamento de altos funcionários da Comissão Europeia a respeito de assuntos chave para a diplomacia comercial do bloco - e assim consiste em fonte de dados valiosa para a análise do posicionamento desses atores, na ausência de possibilidade de entrevista-los.

Quando dados quantitativos referentes ao fluxo comercial entre diferentes países foram necessários, consultaram-se dados disponíveis no site do Eurostat, serviço oficial de estatísticas da UE, bem como aqueles disponíveis na base de dados do MEI (Major Economic Indicators) da OCDE, e também a base de dados da ONU referente a comércio internacional (UN COMTRADE - disponível em http://comtrade.un.org). A fim de se complementar essas fontes, consultou-se o site TrendEconomy (http://www.trendeconomy.com), que sistematiza os dados fornecidos pela ONU, disponibilizando-os conforme a demanda específica dos usuários.

\footnotetext{
${ }^{41}$ Conforme Schade (2016) lembra, embora os pesquisadores devam ser cautelosos no que diz respeito à autenticidade dos documentos, tendo em vista sua fonte não-oficial e publicação, resta pouca dúvida no presente sobre a acurácia da base de dados. Fontes oficiais dos EUA reconheceram a autenticidade desses documentos e emitiram restrições a empregados dos EUA para utilizá-los, e jornais numerosos também pesquisaram o contexto de alguns dos cabos e publicaram reportagens baseadas em informações-chave do arquivo (SCHADE, 2016, p. 53)
} 


\subsection{UE na arena internacional de comércio: estudos de caso}

\subsubsection{Introdução}

No geral, os acordos preferenciais de comércio (APCs) da UE podem ser grosseiramente divididos em três categorias amplas (MCCROSSAN, 2014, p. 84):

1. Acordos com países que são candidatos para, ou que poderiam potencialmente se tornar candidatos para acessão à UE.

2. Acordos com outros países fronteiriços, ou quase-fronteiriços

3. Acordos com países distantes ou grupos regionais.

Conforme enfatizado no capítulo inicial da tese, este trabalho busca analisar as relações comerciais da UE com países que pertencem à terceira dessas categorias. O primeiro caso analisado nesse capítulo trata da política comercial da UE em relação aos BRICS. Como se sabe, a UE não dispõe de política comercial específica para esse bloco de países, principalmente devido à baixa institucionalização do bloco e ao fato de que a UE prefere negociar com regiões em suas relações externas. Assim, esse caso é analisado no quadro de ausência de uma estratégia da UE para a ascensão de novas potências - fato que parece ser mais problemático que a ausência de uma política para os BRICs em si.

Conforme Howorth (2016) explica, é difícil generalizar entre as potências emergentes tanto no que se refere a seus objetivos estratégicos próprios e, especialmente, em termos de seu relacionamento com a UE. A UE estabeleceu parcerias estratégicas com todos os BRICS e os vê conscientemente como entidades separadas com as quais Bruxelas vai forjar abordagens distintas de política. No quadro da EUGS, é especialmente esclarecedor o fato de que o 
documento efetivamente reduz o relacionamento com essas potências à questão da busca por governança global (HOWORTH, 2016, p. 390).

Alguns trabalhos já realizaram uma análise inicial dos BRICS como grupo, a exemplo de Keukeleire e Hooijmeijers (2014); Armijo \& Katada (2014); Roberts et. al (2018). Kirton John (2015, p. 4) explica como “os BRICS cresceram institucionalmente em termos de grau, pertencimento, agenda, intensidade de interação e profundidade”. E Duggan (2015, p.22) chama atenção para o fato de que "os BRICS desenvolveram uma rede grande de interações e institucionalizaram áreas de cooperação”(ZHAO, 2016, p. 5). Porém ainda há a necessidade de mais trabalhos sobre as implicações da consolidação dos BRICS como um grupo. Desta forma, justifica-se a escolha dos BRICS como grupo para estudo de caso, ao abordar-se o aspecto da coesão dessas potências emergentes e seu impacto na ação econômica externa da UE.

O segundo estudo de caso refere-se à manutenção de um desenho de política interregional com os países do GCC (Conselho de Cooperação do Golfo). Semelhantemente ao que ocorre no caso dos BRICs, a UE não tem uma estratégia bem definida para a região do Golfo, ao passo que modelos claros de relações são ou foram oferecidos para regiões como a Europa oriental (alargamento/vizinhança), a região do mediterrâneo (associação e/ou vizinhança), e para a América Latina (associação). Mas o status do GCC ainda permanece indefinido em algum lugar entre mera cooperação e associação (EISSA, 2014, p. 333). Conforme enfatizado na introdução da tese, há poucos estudos que abordam as relações da EU com a região do golfo. No entanto, mais recentemente esse quadro tem mudado, conforme Huliaras \& Kalantzakos (2016) enfatizam. A atenção dos formuladores de política e pesquisadores europeus tem mudado em direção ao Golfo como resultado da Primavera Árabe e da propagação do conflito iraquiano para a Síria. 
Vários artigos têm sido publicados sobre a relação da EU com o GCC, com um viés prevalecente em segurança. A atividade diplomática europeia aumentou também, embora ela ainda não tenha assegurado acordos multilaterais concretos. No entanto, a produção acadêmica continua a ser confinada seja a aspectos de segurança ou secundariamente econômicos das relações do Golfo com o Ocidente ou às políticas externas de alguns países europeus poderosos que tem contatos e fortes e longamente estabelecidos com a região, especialmente o Reino Unido, a França e a Alemanha. (LEGRENZI 2015; ULRICHSEN 2015; BICCHI; CHALLAND \& HEYDEMANN 2015) (HULIARAS \& KALANTZAKOS, 2016).

Desta forma, este estudo de caso também visa a aprofundar o exame da ênfase bilateral da UE (estados membros) com os países do golfo, e a tensão inerente dessa abordagem com a política adotada por Bruxelas no âmbito multilateral. Assim, no caso do GCC não houve uma efetiva europeização da política do bloco (UE), o que tem impedido o aprofundamento das relações UE-GCC, que já se encontram em dificuldade em função da grande diferença em termos de consolidação institucional entre os dois blocos (KOCH, 2014). Adicionalmente, o GCC é o lócus de intensa competição entre Estados e companhias europeias, e apesar de ambos "pregarem a defesa do multilateralismo" (KOCH, 2014, p. 15), poucos colocam essa visão em prática

Em síntese, este capítulo reexamina dois casos empíricos já analisados pela tese do Realismo Comercial (GCC e MERCOSUL), a fim de suprir lacunas nessa abordagem teórica e também analisa um caso negociação com uma coalizão de países (BRICS) e um caso pertencente à categoria dos "mega-acordos" regionais ${ }^{42}$ (TTIP) - complementando assim a

\footnotetext{
${ }^{42}$ Sob a nova administração Juncker, concluir acordos bilaterais com as economias mais importantes na América do Norte e Ásia passou a ocupar um lugar central. Nesse sentido, a UE opta por priorizar imediatamente três acordos, em paralelo com a conclusão do CETA com o Canadá: o TTIP; o acordo com o Japão e o acordo de investimento com a China. O TTIP é o mais ambicioso e estratégico dentre eles. Apenas em termos de tamanho de comércio, o TTIP está no epicentro do debate público no que se
} 
teorização da ação econômica externa da UE formulada por Meissner (2016), que analisava apenas os casos das arenas inter-regional e bilateral.

refere a questões comerciais e regulatórias em ambos os lados do atlântico (DELIMATSIS, 2017, p. $583)$. 


\subsection{Estudo de Caso I: UE-BRICS (2008-2018)}

\section{Introdução}

Apesar da crescente importância do BRICS, a UE não tem nenhuma política genuína “para o BRICS” (UJVARI, 2014; KEUKELEIRE\& DE BRUYN, 2017). Ou tampouco formulou uma política para responder à ascensão, influência e assertividade crescentes de um número crescente de potências emergentes ${ }^{43}$ e "alianças de potências emergentes" (BAVA,2011). Até recentemente, os países BRICS como um grupo eram raramente mencionados em documentos da UE. Isso mudou de alguma forma tendo em vista que no fim de 2011 e início de 2012 o Parlamento Europeu discutiu o tema, levando à elaboração de um relatório sobre a política externa da UE em relação aos BRICS e outras potências emergentes (Parlamento Europeu, 2012). (UJVARI, 2014)

Keukeliere et. al (2011) argumentam que os países BRICS não formam um bloco e portanto não deveriam ser abordados pela UE como um bloco coerente, mas sim como uma rede crescentemente densa e influente que, junto com outras instâncias multilaterais, tem um impacto crescente na governança política e econômica internacional ${ }^{44}$. O impacto dos países BRICS na UE só poderia ser corretamente compreendido se for visto como parte de uma mudança maior no equilíbrio internacional de poder, tanto politicamente como economicamente.

\footnotetext{
${ }^{43} \mathrm{~A}$ ascensão das potências emergentes é claramente manifesta em seu peso crescente nas estruturas de tomada de decisão. As potências emergentes tornaram-se de fato atores com poder de veto: elas podem evitar qualquer resultado insatisfatório, mas não conseguem fazer prevalecer as soluções que preferem (SCHIRM, 2012, p.212). Esse desenvolvimento constitui um desafio fundamental à UE, que ela tem de levar em consideração. (AHNLID \& ELGSTROM, 2014, p. 80)
}

${ }^{44}$ A sinergia mais importante entre os BRICS e a UE provavelmente virá do spill-over tecnológico de IDE da UE nos BRICS (SRINIVASAN, 2014, p.13). 
Por outro lado, Ferreira-Pereira \& Vieira (2016) enfatizam que um dos temas que permeiam as contribuições que se focam nas relações da UE com os países BRICS é a redução da saliência da organização aos olhos de seus parceiros estratégicos. Seja como um resultado da "subperformance" da UE na esfera de política externa e de segurança, ou como consequência da crise da zona do Euro, ou ambos, a UE seria muito menos um ponto de referência chave em termos globais do que foi anteriormente. Ou, conforme Kavalski (2013, p. 251) argumenta, a complexidade da vida global confronta a UE com a realidade de que outros países não a percebem como um magneto: "Essa é uma condição qualitativamente nova para Bruxelas e seu poder normativo - uma situação que parece desconcertar a UE e que ainda não foi tratada adequadamente por ela."

Desde 2003, quando a Estratégia Europeia de Segurança (EES) foi adotada, a UE iniciou "parcerias estratégicas" com todos os BRICS, começando com a China e Rússia em 2003, seguidos pela Índia em 2004 e, finalmente, Brasil e África do Sul em 2007. Ao fazê-lo, a União demonstrou seu desejo de aprofundar a cooperação com países BRICS individuais em desafios globais chave.

Conforme já enfatizado nos capítulos iniciais da tese, as negociações da UE para concluir acordos de livre comércio com BRICS individuais são melhor vistas como parte do aumento no número de APCs desde a conclusão da Rodada Uruguai, enquanto que a Rodada Doha de negociações multilaterais de comércio começou em 2001 e ainda está por ser concluída (SRINIVASAN, 2014, p. 33; GARCIA 2016). A próxima seção deste capítulo analisa brevemente o estado das negociações da UE com os países BRICS individualmente, e em seguida a dinâmica da UE com os BRICS, de grupo para grupo, é abordada a partir da perspectiva do Realismo Comercial. 


\section{BRICS - breve histórico e discussão conceitual do grupo}

Os BRICS diferem entre si em um número de aspectos: culturalmente, politicamente e demograficamente. O que esses países compartilham, no entanto, é uma aspiração de ser "criadores de regras" ao invés de "aceitadores de regras" na governança global. Desde 2006, as nações BRIC começaram a tomar passos para formalizar o grupo. Em setembro de 2008, o primeiro encontro dos ministros de relações exteriores ocorreu, como um evento paralelo à Assembléia Geral da ONU em Nova Iorque ${ }^{45}$. Isso foi seguido por um número de outros encontros entre representantes dos estados BRIC. (REWIZORSKI, 2015, p. 17)

A inovação trazida pela emergência do BRICS passou a ser objeto das discussões acadêmicas nas relações internacionais. Segundo Fonseca Jr (2015), o BRICS possui uma dimensão hacia afuera, voltada para a coordenação das posições destes países nos regimes internacionais e demais instâncias decisórias que regem a governa global, e uma dimensão hacia adentro, voltada para a promoção da cooperação intra-BRICS. Há diferentes definições sobre o modelo de organização dos BRICS - clube (COOPER; FAROOQ, 2015); coalizão (OLIVEIRA; ONUKI, 2013; ABDENUR, 2014); comunidade imaginada (BRÜTSCH; PAPA, 2013) - e acerca do comportamento do agrupamento no cenário internacional - soft balancing (FLEMES, 2010); soft bandwagoning (SPEKTOR apud STUENKEL, 2015); subimperialismo (BOND, 2016) -, os quais tomam como referência diferentes vertentes teóricas das relações internacionais (neorrealismo, institucionalismo neoliberal e construtivismo) e das ciências sociais (marxismo). (DA SILVA \& GOMES, 2018, p. 11)

Ainda vale enfatizar as diferenças de abordagem da UE e dos BRICS em relação ao multilateralismo. A UE parece valorizar os acordos multilaterais e suas provisões, no entanto

\footnotetext{
${ }^{45}$ Apesar do posicionamento em favor dos interesses dos países em desenvolvimento na OMC, e a defesa da Rodada Doha, não houve a criação de uma coalizão formal (AMARAL JR. ET AL. 2015, p. 150)
} 
sem colocar em questão o conceito de soberania. No caso dos BRICS, estes parecem buscar uma reforma das instituições multilaterais criadas nos anos 1950, e que não representariam a população mundial, e também não refletiriam adequadamente a distribuição de poder na arena internacional no início do século XXI. Ademais, esses países exibem uma preocupação com o objetivo de alcançar o desenvolvimento econômico.

Embora a UE já tenha enfrentado desafios externos no passado, a ascensão dos BRICS representa uma nova magnitude de desafio, demandando uma resposta diplomática de espectro completo, cujo aparato diplomático fragmentado da UE é incapaz de gerar (NARLIKAR, 2013). Os BRICS seguem caminhos diferentes de desenvolvimento econômico - de fato, a análise de Nassif et al. (2017) da evolução da economia dos BRICS entre 1980 e 2013 revela diferenças profundas em sua mudança estrutural de longo prazo e performance econômica de. Essas características levam a diferentes desafios e oportunidades para a UE, bem como implicações relevantes para a política do bloco 


\section{Relações UE- BRICS (nível bilateral)}

A UE não pode ser vista como simplesmente estendendo sua rede de parcerias estratégicas, pois compete com outras ofertas atrativas bilaterais e multilaterais feitas por grandes atores internacionais (KAVALSKI, 2015; SMITH 2016). Portanto, a UE tem de considerar tanto a "sombra da China" e o "Guarda-chuva dos EUA" (MURRAY, 2015). (FERREIRA-PEREIRA \&VIEIRA, 2016). Nesse contexto, (Keukeleire, 2011, 2014) argumenta que a melhor abordagem da organização para os BRICS não seria tratá-los como um bloco coerente, mas sim como uma rede crescentemente influente no cenário de mudança de equilíbrio de poder do início do século XXI

Se avaliarmos o lugar que os Estados da coalizão BRICS tem na política externa da UE, é interessante notar seu status de "parceiros estratégicos" do bloco. Como Lessa (2010, p. 128) enfatiza, a expressão "parceria estratégica" é empregada de uma forma relaxada no jargão e documentos da União Europeia ${ }^{46}$. Dentre os 14 parceiros estratégicos da UE, quatro países (Brasil, China, Rússia e Índia), representam as maiores economias emergentes.

\section{Brasil}

A primeira cúpula UE-Brasil aconteceu em Lisboa em julho de 2007. Tópicos centrais da nova parceria incluem o multilateralismo efetivo, mudança climática, energia sustentável, a luta contra a pobreza, o processo de integração do Mercosul e a estabilidade e prosperidade da América Latina. O comércio é um assunto importante de diálogo, visto que o Brasil é o mercado

\footnotetext{
${ }^{46} \mathrm{O}$ significado de parceria estratégica não foi claramente definido, seja nos extensos documentos referentes à política comum externa e de segurança (CFSP), ou nos tratados europeus. Ao mesmo tempo, a rationale para o estabelecimento de uma parceria estratégica nunca foi objetiva, e tem variado de país a país. Mesmo na primeira reunião do Conselho Europeu após o tratado de Lisboa, não se chegou a um consenso sobre o significado da expressão. (FERREIRA-PEREIRA \& VIEIRA, 2016)
} 
mais importante para a UE na América Latina. (EUROSTAT, 2012, p. 7). No entanto, a promessa de relações mais próximas da EU com o gigante sul-americano parecem mais restritas ao plano do discurso, e o Brasil não aparece uma única vez no texto da EUGS de 2016.

A busca de relações mais próximas com o país Sul-americano parece, essencialmente, ter sido motivada pela competição com os EUA, mas também foi impulsionada a partir da entrada de Portugal e Espanha na comunidade europeia na década de 1980. Com o aprofundamento da crise política no Brasil a partir de 2016, as perspectivas para a conclusão de um acordo de livre-comércio bi-regional tornaram-se menos promissoras, apesar do discurso oficial brasileiro de otimismo em relação à assinatura do acordo. Efetivamente, 20 anos de negociação trouxeram pouco progresso nesse sentido, a exemplo da última cúpula do Mercosul, que buscou cooperação maior com a UEE (União Econômica Eurasiática).

\section{Rússia}

A cooperação em curso com a Rússia é baseada em 4 áreas específicas de política. Esses "espaços comuns" cobrem assuntos econômicos e meio-ambiente; liberdade, segurança e justiça; segurança externa; e pesquisa e educação, incluindo aspectos culturais. A UE e a Rússia concluíram um acordo de parceria e cooperação em 1994. As negociações para um novo acordo UE-Rússia foram lançadas em junho de 2008. O novo acordo deveria atualizar e substituir o acordo existente "Acordo para parceria e cooperação", fornecendo um quadro abrangente para as relações UE-Rússia (EUROSTAT, 2012, p. 7)

As relações entre a UE e Rússia encontram-se atualmente "congeladas" conforme enfatizou um especialista ${ }^{47}$ (HOWORTH, 2016). Como consequência da intenção europeia de estabelecer relações mais próximas com os países do espaço pos-soviético - a partir de 2009 no quadro da EaP (Parceria Oriental), a Rússia lançou a ideia de criar uma união aduaneira

\footnotetext{
${ }^{47}$ No entanto, Moscou mantém proximidade com estados importantes da UE: Itália, Alemanha, Polônia.
} 
juntamente com a Bielorrússia e o Cazaquistão ${ }^{48}$. No entanto, o posicionamento da UE de oferecer um DCFTA à Ucrânia em 2013 gerou uma contra-resposta Russa com a subsequente invasão e anexação da Criméia. Em síntese, Putin parece ter reagido com destreza à incapacidade da UE de deixar clara sua intenção em relação à Rússia, especialmente após sua reeleição.

${ }^{48}$ A União Aduaneira entrou em vigor em $1^{\circ}$ de janeiro de 2010. 


\section{Índia}

A UE e a República da Índia beneficiam-se de uma parceria de longa data, que remonta ao início da década de 1960. O comunicado político conjunto de 1993 e o acordo de cooperação de 1994, que é o atual quadro legislativo para cooperação, abriram a porta para um diálogo político amplo, que evolui por meio de cúpulas anuais, e encontros ministeriais regulares e encontros de especialistas. Em 2004 a Índia se tornou um dos "parceiros estratégicos" da UE. Desde 2005, o Plano de Ação Conjunta está ajudando a realizar o potencial total dessa parceria em áreas-chave de interesse para a Índia e para a UE. (EUROSTAT, 2012, p. 8)

As negociações para um acordo de livre-comércio, iniciadas em 2007, parecem não ter progredido significativamente. A Índia intensificou a cooperação com os países do GCC, e também tem comprado equipamentos militares modernos dos EUA, embora seu programa de modernização de caças tenha dado preferência à Rafale, em detrimento do caça de quatro países “Eurofighter". De acordo com um especialista proeminente, a UE tem diminuído em relevância para a Índia, especialmente pela incapacidade europeia de compreender a dinâmica regional em que se encontra o parceiro Asiático (KAVALSKI, 2016).

\section{China}

As relações da UE com a China foram estabelecidas em 1975 e são governadas pelo acordo de cooperação e comércio de 1985. A UE é o maior parceiro comercial da China, ao passo que a China é a maior fonte de importação da UE e o segundo maior parceiro comercial (em dois sentidos). A fim de refletir a profundidade e amplitude de sua parceria estratégica estabelecida em 2003 - a UE e a China decidiram em 2010 atualizar suas relações bilaterais em assuntos externos, questões de segurança e desafios globais tais como mudança climática, a 
recuperação da economia global, para mencionar apenas algumas áreas ${ }^{49}$. Cúpulas anuais são realizadas e diálogos políticos, comerciais e econômicos ocorrem, incluindo mais de 50 diálogos e acordos setoriais, variando de proteção industrial a política industrial, educação ou cultura. (EUROSTAT, 2012).

A UE está negociando um acordo de investimento com a China, refletindo a mudança recente da economia chinesa de exportadora de mercadorias, para exportadora de investimentos. Conforme Howorth (2016) enfatiza, o peso das relações comerciais entre a UE e a China deve-se essencialmente às relações de países europeus individuais e suas respectivas empresas com a China, ao invés da ação coletiva europeia. Face ao déficit em termos de demanda, esses atores têm relaxado suas exigências em relação a normas de democracia e direitos humanos vis-à-vis a China.

\section{África do Sul}

A África do Sul representa o único país BRICS a ter concluído um acordo de livre comércio com a UE. Tendo em vista que a África do Sul é parte da UAAA (União Aduaneira da África Austral) ${ }^{50}$, o acordo com a UE é na prática um acordo UE-SADC (Comunidade para o Desenvolvimento da África Austral). O acordo foi assinado em 2000, após quatro anos de intensas negociações - em um contexto em que o país sul-africano buscava uma reinserção na

\footnotetext{
${ }^{49}$ A China tem pressionado a UE a fim de envolve-la no projeto OBOR (One Belt One Road). A Europa desempenhou um papel histórico na antiga Rota da Seda e claramente seu envolvimento é essencial para a realização do projeto. (PICCIAU, 2016, p.4)

${ }^{50}$ A UAAA foi criada em 1910, e foi tradicionalmente administrada pela África do Sul. Uma tarifa externa comum aplica-se aos países não-membros dessa união aduaneira. A África do Sul é a economia mais aberta dentre os países BRICS, com o comércio exterior representando $64 \%$ do PIB. No caso do Brasil, o país com a economia mais fechada dentre essas potências emergentes, o comércio exterior representa apenas 26\% do PIB (dados de 2014). Com base nos dados mais recentes disponibilizados pelo Banco Mundial, de 2017, esses valores são de 24\% para o Brasil e de 58\% para a África do Sul.
} 
economia global após o período do apartheid. Ademais, um dos objetivos principais do acordo foi impulsionar o comércio intra-SADC (LEE, 2002).

À época, o acordo foi o mais ambicioso do gênero a ter sido assinado pela EU, com um país tão distante geograficamente, no entanto, a partir da estratégia Global Europe 2006, observadores passaram a criticar a política comercial europeia para a África. Assim, Goodison (2007, p.150) explica que muitas companhias sul-africanas foram compradas ou entraram em parceria com empresas europeias - apenas pela mera expectativa de conclusão do acordo de livre-comércio. Em síntese, estaria em curso uma estratégia de "re-colonização do continente", como consequência da combinação da P.A.C. (política agrícola comum) da estratégia comercial da UE.

Mais recentemente, em junho de 2016, a EU assinou um acordo de parceria econômica com a SADC - e o tratado entrou em vigor em outubro do mesmo ano. Em adição às cláusulas referentes ao comércio, o acordo entre as partes (que no caso da SADC incluem Botswana, Namíbia, Lesoto, Suazilândia e Moçambique), também traz provisões relativas a normas de meio-ambiente e sustentabilidade (COMISSÃO EUROPÉIA, 2017). Esse tratado passou a ser o primeiro APE regional a estar totalmente operacional, após o início da participação de Moçambique em fevereiro de 2018.

\section{Síntese - relações UE BRICS no nível bilateral}

Em resumo, o nível e tamanho dessas relações varia enormemente, com a África do Sul, representando uma parcela muito pequena das relações comerciais da UE, enquanto que a China e Rússia são parceiros significantes em muitas áreas. O caso da Rússia é interessante, porque apesar de sua interdependência, as relações entre a UE e a Rússia são complicadas pelos eventos na Ucrânia e Síria. Como resultado, a Rússia tem usado o BRICS como um fórum para 
encontrar parceiros para compensar os efeitos negativos das relações abaladas com a UE. Isso sublinha o que Gratius $(2013$, p. 6) descreve como um fardo estrutural que precisa ser superado a fim de aprofundar suas relações: "para a UE, vai ser muito mais fácil depender de aliança tradicional em questões globais do que mover em direção às posições dos países BRICS altamente influenciados pela interpretação tradicional de soberania nacional, Realpolitik e nãointerferência em assuntos internos"

Figura 4: Exportações agregadas da UE-27 para os estados BRIC (milhões de Euro)

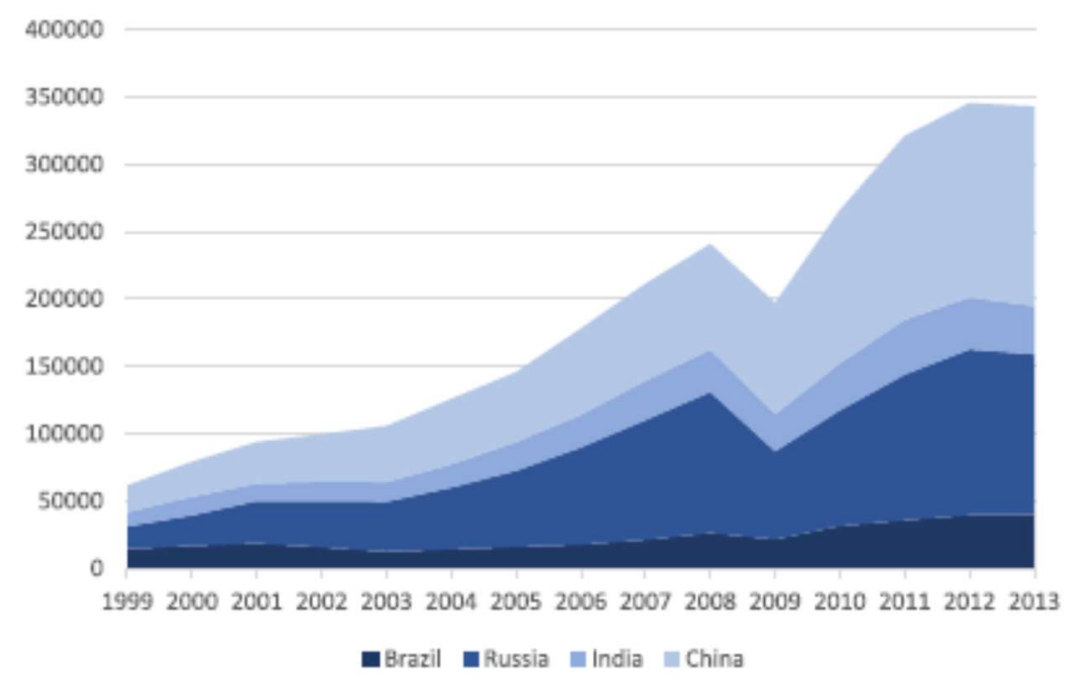

Fonte: Feedoseeva \& Zeidan (2016, p. 238)

O gráfico acima ilustra o peso da economia chinesa em relação aos demais países membros do BRIC, reforçando a percepção de que - sem a China - os BRIC poderiam ser um grupo com relevância muito menor na governança econômica global ${ }^{51}$. A partir da figura acima também se percebe o crescimento quase constante das exportações europeias para essas novas potências econômicas, bem como a demanda por produtos europeus detêm potencial de

\footnotetext{
${ }^{51}$ Rothkopf (2009) escreveu que, sem a China "os BRIC são apenas o BRI, um queijo brando, mole, que é mais conhecido pelo vinho com que é servido"
} 
impulsionar o crescimento da indústria na UE. Assim, vale ressaltar a análise de um dos raros trabalhos que analisam exportações da UE para os BRICS, sobre as seguintes consequências para o desenho de futuros acordos de comércio entre a Europa e os BRICS:

"a primeira é que porque os padrões de comércio são estáveis, os países poderiam beneficiar-se ao liberalizar o comércio, especialmente para os produtos elásticos em demanda. A segunda é que a resposta assimétrica aos movimentos da taxa de câmbio é uma característica importante das exportações europeias para os países BRIC, o que significa que argumentos em favor de desvalorizações competitivas de moedas podem não ter um efeito significativo sobre o comércio, especialmente se as exportações reagem mais a apreciações do que a depreciações. [..] A terceira é que [...] ao focar-se em determinantes de longo prazo, pode-se demonstrar com confiança, por exemplo, que em setores inelásticos é possível assumir um impacto menor de acordos de comércio sobre o valor de exportação. " (FEDOSEEVA \& ZEIDAN, 2016, p. 244)

Assim, o elemento mais relevante dessa análise econométrica parece ser o de que desvalorizações competitivas podem não ter efeito significativo sobre o comércio, uma estratégia que a China (e os EUA) comprometeram-se a evitar em outubro de $2018^{52}$. Tendo analisado aspectos das relações da UE com os BRICS considerados individualmente, a próxima seção do capítulo muda o foco analítico para os BRICS como grupo ou região. E em seguida passa-se à análise do posicionamento da UE na arena do comércio em relação a essas potências emergentes, levando em consideração as variáveis independentes extra-regionais e intraregionais.

\footnotetext{
52 "IMF members pledge to avoid competitive currency devaluations". The Straits Times. Disponível em: https://www.straitstimes.com/asia/se-asia/imf-members-pledge-to-avoid-competitive-currencydevaluations.
} 


\section{BRICS como uma região}

A resposta da UE à emergência dos BRICS como uma força potencialmente unificada na arena global varia. Interessantemente, quanto mais bem-sucedido o grupo tem sido em se opor ou bloquear a postura da UE ao formar um bloco em determinada arena de política, mais provável é que referências - e abordagens - coletivas a esses países possam ser encontradas. (UJVARI, 2015, p. 4)

Ao procurar similaridades entre os países BRICS, dois aspectos importantes podem ser sublinhados: 1) os países BRICS são potências regionais em suas respectivas regiões, e 2) os estados BRICS individualmente são produtos da fase recente de globalização e seus processos relacionados. Ambos os princípios mencionados anteriormente, de conceituar o espaço, são aplicáveis aos BRICS como um grupo. Para os países BRICS, as categorias sócio espaciais relevantes anteriormente à fase recente de globalização eram o "Terceiro Mundo", economias em desenvolvimento e o Sul Global, ou é assim que eles eram representados. A narrativa inicial era de que eles estavam lutando pelos níveis de desenvolvimento já alcançados pelo Ocidente e seguindo modelos lineares similares de crescimento e desenvolvimento. (MEENA, 2013, p. 587)

Conforme Meena (2013, p. 587) enfatiza, será difícil analisar e justificar os BRICS como uma região, por meio das concepções tradicionais de região que privilegiam a contiguidade geográfica, homogeneidade e colocam a "região" em uma escala abaixo do estado. A abordagem da ecologia política, com suas inclinações em direção à produção social de espaços e lugares e o mandato para analisar a espacialidade das relações sociais, permite essas formações regionais. Tendo em vista que as regiões são formações discursivas, as relações de poder estão embutidas nelas, o que favorece determinada formação em detrimento de outras. 


\section{Evolução da institucionalização dos BRICS}

A partir do trabalho empírico de Zhao (2016), é possível identificar três fases na institucionalização dos BRICS: embrionária; emergente e de semi-institucionalização

Estágio embrionário (2005-2008): esse é um estágio rudimentar que estabelece o tom para os BRIC com potencial de desenvolvimento adicional. Nos três primeiros anos, as interações dos BRIC foram informais e aconteceram apenas em nível ministerial às margens da Assembleia Geral da ONO. Durante esse estágio, 2008 - o início da crise financeira - foi um ponto-chave para que o BRIC começasse a se desenvolver. Em 16 de Maio de 2008, os ministros de relações exteriores dos BRIC tiveram sua primeira reunião e publicaram seu primeiro comunicado. (ZHAO, 2016, p. 11)

Estágio emergente (2009-2013): esse é um estágio importante da institucionalização dos BRIC(S), durante o qual os contornos do quadro BRICS foram construídos e expandidos. Como é amplamente reconhecido, o ano de 2009 foi um marco para os BRIC formalizarem o grupo. A primeira cúpula dos BRIC ocorreu em Yekaterinburg a partir de uma iniciativa russa, e os líderes dos países BRIC emitiram seu primeiro comunicado conjunto de alto nível.

Estágio de semi-institucionalização (2014-período atual): considerando a materialização da primeira instituição BRICS visível, esse estágio é marcado por um progresso significativo para a institucionalização do BRICS como um grupo. Em termos de aprofundamento da profundidade de cooperação, a $6^{\mathrm{a}}$ Cúpula dos BRICS em 2014 (Fortaleza) produziu um resultado altamente importante - o acordo do NBD e o Tratado para o 
Estabelecimento do CRA - foram assinados pelos líderes dos BRICS. As duas instituições possuirão um total de 200 bilhões de dólares. Ademais, em 2015 e 2016 os BRICS consolidaram e aceleraram sua cooperação na dimensão financeira por meio da nova instituição. (ZHAO, 2016, p. 12).

\subsubsection{Coesão}

Esta seção analisa a evolução da coesão dos BRICS no período de 2009 até o período atual, porém utiliza-se o índice apresentado no capítulo anterior apenas no período de 2014 até o ano corrente, devido ao estágio embrionário da institucionalização do bloco até o ano de 2013. Nesse período inicial, a coalizão tem pontuação igual a zero nos indicadores listados por Meissner (2016) - e foi marcado justamente pelo caso mais claro em que falharam em cooperar: na indicação do novo chefe do FMI em 2011-2012 (ROBERTS ET AL, 2018, p. 107)

Um caso raro em que os BRICS demonstraram unidade em instituições internacionais ${ }^{53}$ foi o da Cúpula do G20 em Toronto em 2010, em que esses países negociaram com os EUA e a UE. Entre outros tópicos, tais como mecanismos para estimular o crescimento econômico e reduzir o endividamento em economias desenvolvidas, as conversas focaram-se na adoção de um imposto bancário internacional (REWIZORSKI, 2015).

Há casos em que os países BRICS pediram consultas uns contra os outros, apesar do acordo informal de não o fazer. Até 2013, houve apenas dois casos registrados entre países BRICS na história da OMC - entre Brasil e Índia, e entre Brasil e África do Sul - e ambos os casos foram resolvidos por entendimentos bilaterais (AMARAL JR. ET. AL., 2015, p. 152). Posteriormente, houve um caso entre Índia e China (Taipei) em 2015, e mais recentemente

\footnotetext{
${ }^{53}$ Nota-se também a criação do Fórum dos BRICS em 2011, com o objetivo de fazer avançar os interesses dos países membros, especialmente em assuntos sócio-economicos e políticos, bem como promover um diálogo entre os povos desses Estados. (GATEWAY HOUSE, 2016)
} 
China - Brasil em 2018 (importações de açúcar). Em 2017 os países BRICS avançaram a ideia de criar um fórum para a resolução de disputas comerciais, que seria dotado de um conselho diretor e de regras comuns de arbitragem.

Um dos desafios principais que os BRICS enfrentam é que eles permanecem relativamente isolados uns dos outros. À exceção da China, que tem laços econômicos fortes com todos os outros BRICS, o comércio intra-BRICS é surpreendentemente baixo. O comércio do Brasil com a Índia, por exemplo, é de apenas \$10 bilhões, sete vezes menor que os laços econômicos do Brasil com a China. O mesmo se aplica para os outros BRICS, cujo comércio é dominado pela China. O comércio intra-BRICS no total é menor que o comércio dos BRICS com a África, mostrando o quão frouxamente os BRICS são de fato interdependentes. Dada a falta de coesão substantiva, a agenda de cooperação intra-BRICS foca-se hoje em tópicos como saúde pública, facilitação de comércio, agricultura, cidades, coleta de impostos, estatísticas, cooperativas, academia, o judiciário e defesa. Esses tópicos tratam de cooperação econômica mais baixa. Por outro lado, os governos estabeleceram um grupo de iniciativas para encontrar formas de aumentar conexões, entre elas encontros regulares de ministros de comércio; autoridades de competição, o fórum de cooperativas dos BRICS; e o Fórum de Negócios dos BRICS (QUILICONI ET AL., 2016, p. 45)

Ainda no que se refere ao comércio intra-BRICS, há pouca complementaridade entre os países que compõem o bloco, e, no que se refere aos investimentos, concentram-se no tipo de busca de recursos ("resource seeking") (BAUMANN, 2013). Ainda assim, o BRICS totaliza \$230 bilhões de comércio intra-bloco. O comércio intra-BRICS era de apenas 27.3 bilhões de dólares em 2002, e chegou a 300 bilhões em 2014, e a parcela combinada dos BRICS no comércio internacional foi de $18 \%$ no mesmo ano ${ }^{54}$ (FMI, 2014) (PRABHAKAR, 2015).

\footnotetext{
${ }^{54}$ No entanto, o comércio intra-BRICS representa menos de $10 \%$ do comércio total dos países; o comércio fora dos Brics chega a mais de $90 \%$, assim, embora haja um pequeno aumento dentro do grupo, esse aumento é pequeno quando se leva em consideração o quão grande os mercados são. (ALMEIDA
} 
Assim, em termos de convergência de comércio, os BRICS avançaram em direção a maior coesão nesse período.

A evidência da colaboração entre os BRICS pode ser encontrada em mais de dez anos de comunicados conjuntos, e outros pronunciamentos públicos de líderes e oficiais, além de entrevistas conduzidas por especialistas, conforme Roberts et al. (2018) explicam. Durante a presidência russa dos BRICS em 2015-2016, mais de dez encontros ministeriais e cerca de vinte encontros de especialistas foram agendados. Na sétima cúpula de Chefes de Estado em Ufa, na Rússia, mais de setenta e sete itens de reuniões entraram na declaração oficial. E durante o patrocínio indiano da $8^{\text {a }}$ Cúpula de Chefes de Estado dos BRICS, em 2016, a declaração oficial de Goa incluiu mais de 110 itens de agenda (ROBERTS ET AL., 2018, p. 70).

Em síntese, os BRICS tem avançado em direção a uma maior coordenação de política além da área financeira, incluindo os setores de: comércio, saúde, meio-ambiente, migração e política externa; porém, conforme Zhao (2016) explica, essas iniciativas ainda não conseguiram gerar interesses comuns a ponto de gerar uma força coesiva. Assim, a partir do índice desenvolvido por Meissner (2016), é possível afirmar que os BRICS têm um grau de coesão muito baixo, pontuando apenas em dois itens da escala ${ }^{55}$ : unidade em cúpulas presidenciais (9) e convergência de comércio (12).

\& SILVA, 2018, p. 16). Mais especificamente no que se refere a exportações intra-BRICS, há uma clara tendência de queda a partir de 2013, em função da desaceleração econômica na China (KOLLAMPARAMBIL, 2017, p. 39).

${ }^{55}$ Os indicadores de números 4, 5 e 6 referem-se a instituições supranacionais e portanto não se aplicam ao caso dos BRICS. 
Tabela 13: Coesão dos BRICS (2014-período atual)

\begin{tabular}{|c|c|c|}
\hline Coesão & Indicador & Pontuação \\
\hline \multirow{6}{*}{$\begin{array}{l}\text { Política } \\
\text { Intra-Regional }\end{array}$} & Número de disputas comerciais (1) & \\
\hline & Intensidade de disputas comerciais (2) & \\
\hline & Solução de disputas comerciais (3) & \\
\hline & Instituições supranacionais (4) & --- \\
\hline & Aprofundamento de instituições (5) & --- \\
\hline & Alargamento de instituições (6) & --- \\
\hline \multirow[t]{5}{*}{$\begin{array}{l}\text { Política } \\
\text { Extra-regional }\end{array}$} & $\begin{array}{l}\text { Unidade em instituições internacionais } \\
\text { (7) }\end{array}$ & \\
\hline & Unidade em áreas não-reguladas (8) & \\
\hline & Unidade em cúpulas presidenciais (9) & $\mathrm{X}$ \\
\hline & Prioridade de parceiro de negociação (10) & \\
\hline & Prioridade de matéria de negociação (11) & \\
\hline \multirow{4}{*}{$\begin{array}{l}\text { Assuntos } \\
\text { Econômicos }\end{array}$} & Convergência de comércio (12) & $\mathrm{X}$ \\
\hline & Investimento por parceiro (13) & \\
\hline & Tipo de comércio (14) & \\
\hline & Tipo de investimento (15) & \\
\hline Soma & & 2 \\
\hline
\end{tabular}




\subsubsection{Competição com atores rivais}

O atual cenário internacional é particularmente desafiador para a UE, pois tem de levar em conta não apenas a competição com os EUA - em sua formulação de política externa - mas também as demandas dos BRICS. No entanto, conforme Keukeleire \& Bruyn (2017) enfatizam, não há sinais de que a UE consiga adaptar sua estratégia à nova realidade internacional, ou de que os BRICS aceitem esse novo posicionamento, tendo em vista sua percepção do declínio em curso da União Europeia. Outro fator complicador são as estratégias individuais dos estados membros da UE para os BRICS, que se somam à complexidade crescente da governança econômica global, conforme ilustrado na Figura 6.

Figura 5: Alianças de potências emergentes e outros quadros multilaterais

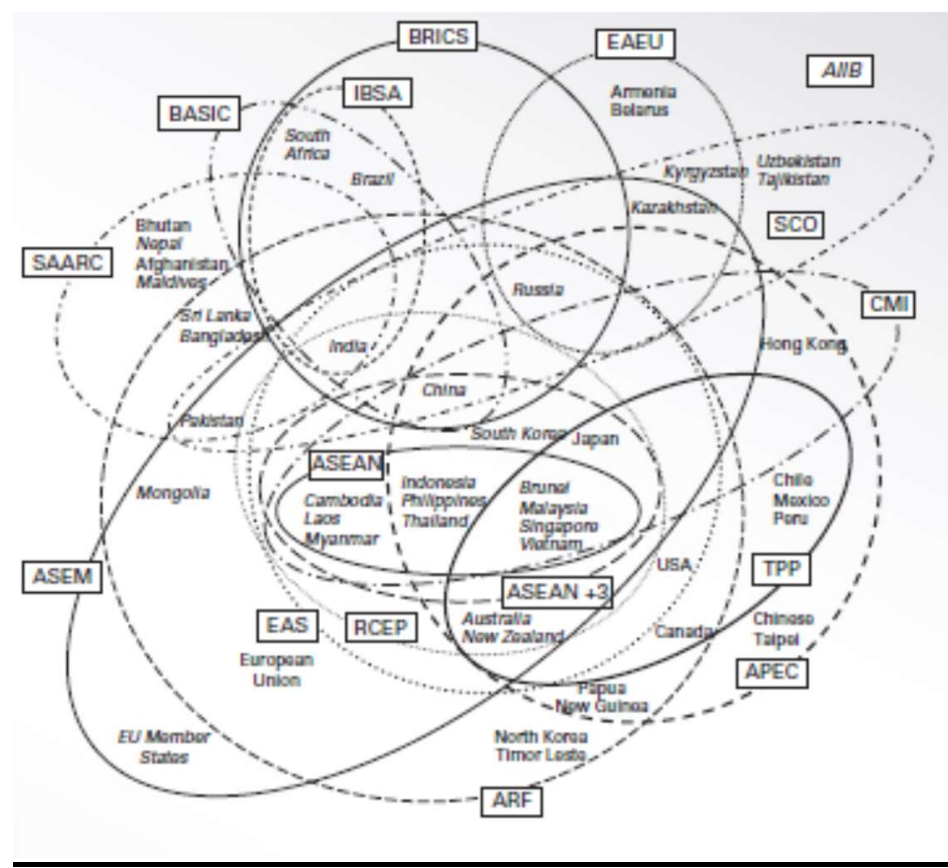

Fonte: Keukeleire \& De Bruyn (2017, p. 437) 
Para a UE, a diplomacia econômica emergente dos BRICS é particularmente importante por causa do próprio declínio econômico e financeiro da UE. A crise econômica que se iniciou em 2008 abalou seriamente a confiança política da UE. Para o Sul Global, a crise de 2008 tem sido uma mudança de paradigma (à semelhança do que o 11/9 foi para o Ocidente), uma vez que ela pareceu confirmar que o modelo Ocidental (abraçando o neo-liberalismo) estava gradualmente dando lugar ao modelo Chinês (em que um estado forte gerencia um mercado vibrante). Mais recentemente, os países ocidentais de renda-alta têm retomado seu papel como impulsionadores do crescimento econômico internacional, ao passo que os BRICS (com a exceção da Índia) estão sofrendo de uma desaceleração estrutural. (CLINGENDAEL, 2015, P.13)

Os BRICS têm ampliado sua agenda para incluir "novos desafios" relacionados a desigualdades, política de protecionismo, isolacionismo, falta de confiança", de acordo com Svetlana Lukash. Isso visa a uma ordem mais equilibrada e democrática com o objetivo fundamental de crescimento, ao invés de ser um substituto para outras organizações internacionais. Essa ideia de complementariedade tem sido enfatizada em diferentes instâncias. Pavel Knyazev (2016) nota que o BRICS desempenha um papel de liderança e serve de exemplo: “as agendas políticas dos estados BRICS podem não coincidir às vezes, mas na filosofia dos BRICS não existe nada 'anti', os BRICS são sempre um pró- e não um contra-. Isso não significa, no entanto que não haja um 'objetivo geopolítico de contrabalanceamento', que para a compreensão do grupo é necessário conferir mais justiça à ordem internacional. Esse posicionamento tem permitido a mudança de um "conjunto liberal-unilateral de reivindicações sociais para outro, desenvolvimentista-multipolar" (MIELNICZUK, 2013, p. 1087). (FREIRE, 2017, p. 191) 


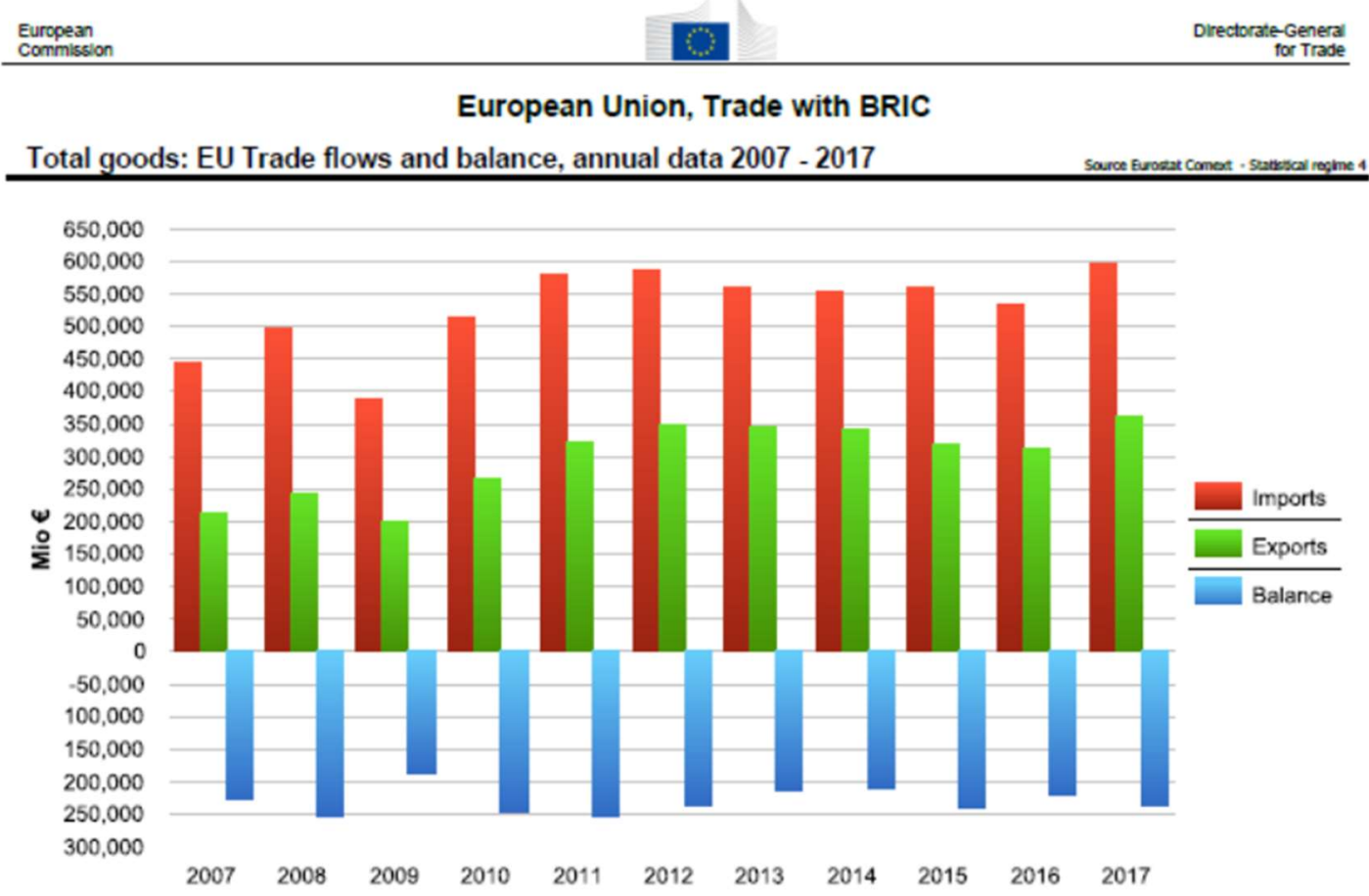

Fonte: Comissão Europeia (2018)

Assim, o gráfico acima ilustra que o fluxo comercial de importações dos países BRIC para a Europa manteve-se relativamente estável após a crise de 2008/09, prevalecendo a situação de déficit para o bloco europeu. No entanto, a maior parte desse comércio está concentrado (>90\%) em três clusters, conforme a contribuição recente de Fedoseeva \& Zeidan (2016) demonstrou - e a demanda dos BRIC por produtos europeus poderá trazer um renascimento da indústria no continente. Igualmente, esse estudo demonstrou que não há competição intensa com outras exportações nos países BRIC, diferentemente do que as empresas europeias encontram no mercado altamente saturado dos EUA. 
O primeiro dos clusters $^{56}$ mencionados no parágrafo anterior inclui exportações que crescem com a renda, a exemplo da maior parte das exportações europeias para a Índia, e exportações de maquinário alemãs para a China. O segundo cluster é formado por modelos com demanda de exportação inelástica, e é dominado em boa parte por exportações para o Brasil, e exportações não-alemãs de maquinário para a Rússia e China. O terceiro cluster inclui muitas exportações para a Rússia, e tem reações assimétricas a movimentos na taxa de câmbio (FEDOSEEVA \& ZEIDAN, 2016, p. 244).

Em síntese, os dados empíricos analisados nesta seção sugerem uma baixa competição entre a UE e atores rivais em relação aos BRICS no período de 2008 a 2018. Conforme enfatizado na introdução do trabalho, são raros os estudos que abordam as exportações da UE em relação a esses países, e há necessidade de uma melhor compreensão de como fatores estruturais, ou dinâmicas políticas internas aos BRICS influenciam a demanda por produtos europeus $^{57}$. Isso especialmente no período mais recente, após 2014, de maior institucionalização da coalizão BRICS, que também foi marcado por tensões entre a UE e a Rússia, bem como pelo agravamento da crise política no Brasil.

\footnotetext{
${ }^{56}$ Para o período de 1999 a 2013 levado em consideração no estudo citado.
}

${ }^{57}$ Vide a recomendação do estudo pioneiro de Fedoseeva \& Zeidan (2016). 


\subsubsection{Nexo entre política externa e política comercial}

Apesar de se encontrarem desde 2009, os BRICS não conseguiram desenvolver uma identidade coletiva genuína, nem a UE foi capaz de desenvolver uma estratégia coerente em relação a eles, mesmo levando em consideração que foram identificados como parceiros estratégicos (Smith et al., 2016). Um dos poucos trabalhos que abordam a questão (UJVARI, 2014) chegou à conclusão de que apenas no que se refere a questões de mudança climática é possível afirmar que há uma resposta eficaz da UE ao crescimento do poder dos BRICS - um domínio em que a competência da UE para agir no plano internacional é compartilhada com a dos Estados-membros. Nos domínios do comércio internacional (competência exclusiva) e da segurança internacional não seria possível sustentar o mesmo argumento

Até o presente, nenhuma das reuniões dos ministros de comércio da UE foi marcada pela elaboração de decisões ou de conclusões contendo uma referência coletiva aos países do BRICS $^{58}$ ou a uma de suas variantes, tal como os países do BASIC (Brasil, Índia, África do Sul e China) ou IBAS (Índia, Brasil e África do Sul). No que concerne os grupos de trabalho do Conselho de Relações Exteriores, eles seguem uma divisão temática e geográfica - nenhum grupo estando consagrado às alianças estratégicas de potências como os BRICS. (UJVARI, 2014, p. 16)

\footnotetext{
${ }^{58}$ Em um evento recente sobre as relações entre UE e os BRICS, a embaixadora do Brasil na Alemanha também afirmou não considerar "o BRICS como um grupo negociador, mas as economias BRICS são importantes umas para as outras e elas tem ajudado a sustentar o dinamismo da economia mundial durante a crise recente. Elas tem mesmo ajudado o FMI assistir países que foram particularmente atingidos". Igualmente a diplomata sublinha que embora a crise tenha reduzido o crescimento nos países BRICS, classes médias grandes desenvolveram-se ali, formando um mercado de consumo importante. Assim, considera que a OMC deveria ser mais utilizada como um fórum para melhorar relações de comércio. (CESIFO, 2014, p. 35)
} 
No que concerne os documentos oficiais produzidos pela Comissão Europeia, e mais especificamente do Diretoria Geral do Comercio - nota-se a ausência do grupo dos BRICS na publicação "Trade, growth and world affairs" de novembro de 2010, que é ainda um documento importante para as políticas adotadas pela UE. Nesse sentido, fica evidente a escolha do bloco em lidar com esses cinco países de forma individual. No entanto, o fato de que a Comissão publica estatísticas regularmente sobre o comércio com os BRICS evidencia uma tomada de consciência do órgão sobre a capacidade dos cinco países de impactar o comércio global por meio da ação como bloco. (UJVARI, 2014, p. 14).

No que se refere a política externa, uma abordagem bilateral parece continuar como o modus operandi principal para as relações UE-BRICS. Testemunho disso foi o discurso proferido pela então AR/VP Catherine Ashton, em 2012, sobre a "Política Externa da UE em relação aos BRICS", que mandou uma mensagem muito clara: a UE deve tratar os BRICS como países individuais por meio das respectivas parcerias estratégicas ${ }^{59}$. No entanto, aqui também, o Parlamento Europeu reconheceu as ações coletivas dos BRICS, notando em uma resolução de 2012 que eles estão crescentemente propensos a agir como grupo em termos de política externa.

Embora sejam raros os trabalhos, ou mesmo documentos oficiais da UE, que abordam as relações da organização com os BRICS como grupo, é mais problemático o fato de que a UE não tenha uma política para lidar com a mudança geral no equilíbrio de poder no século 21 (KEUKELEIRE \& DE BRUYN, 2017, p. 424). Nesse sentido, Allen \& Smith (2012) enfatizam

\footnotetext{
${ }^{59}$ Durante uma participação da diplomata em evento no Brasil, no Instituto Rio Branco, no mesmo ano - ela também fez referência breve ao grupo dos BRICS, mas enfatizando as diferenças entre esses países, e o fato de que a UE deveria abordá-los de maneira individual no quadro de parcerias estratégicas (ASHTON, 2012). Inclusive, chamou atenção para o fato de que não faria sentido agrupar esses países e assumir que adotariam "uma visão comum em tudo".
} 
a existência de uma diplomacia estratégica da UE, no entanto, parece evidente que até o presente tal evolução ainda não ocorreu (ALLEN, 2013; KAVALSKI, 2016). Daí a avaliação de Freire (2017), de que prevaleceria uma “disjunção estratégica” entre os dois atores:

"O potencial do multilateralismo de promover a cooperação e integração informal benignamente não está sendo alcançado de fato nas relações UE-BRICS, em que o canal bilateral claramente define interesses e fixa agendas. Consequentemente, no sistema de governança global a UE e os BRICS reconhecem a relevância do "outro", mas permanecem separados em questões fundamentais, especialmente no que se refere a redesenhar a ordem internacional para ser mais inclusiva, em parte devido à dinâmica de socialização/resistência no discurso e prática "anti-Ocidente" e "com o Ocidente". Apesar das oportunidades para integração mais profunda, especialmente aquelas derivando de atividades econômicas, as dificuldades de enquadrar essa integração informal em uma parceria estratégica são evidentes. A disjunção estrutural parece prevalecer. (FREIRE, 2017, p. 194)"

Assim, em síntese, a atuação da UE em relação aos BRICS na arena comercial não se dá de forma coerente com os demais domínios da ação externa europeia. No campo das questões relativas a negociações do regime de mudança climática é onde a UE posiciona-se de forma mais próxima a uma "diplomacia estratégica", o que não em ocorre questões de segurança ou comércio internacional. A análise das fontes primárias e literatura secundária tampouco permite afirmar que o período pós-Lisboa trouxe uma maior coordenação entre as instituições de comércio e política externa da UE em relação a potências emergentes.

\subsubsection{Preferências das instituições da UE}

Mandato de negociação

Tendo em vista a impossibilidade da UE ter um mandato de negociação para um acordo de livre comércio com os BRICS como grupo, em função do fato de que o BRICS não é uma região tradicional, esta seção do capítulo analisa a atenção que o grupo recebeu, desde sua 
criação em 2008, no maquinário institucional da UE. Nesse sentido, são analisados documentos produzidos no âmbito do parlamento europeu, Conselho e Comissão, com vistas a avaliar a atenção dedicada por formuladores de decisão à atual mudança no equilíbrio de poder no sistema internacional, e o (não) posicionamento estratégico europeu em relação ao fenômeno. Como data limite da análise fixou-se o ano de 2016, que marca a publicação da EUGS (Estratégia Global da UE)

Conforme Gratius (2013, p.4) enfatiza: “nem a UE, nem os BRICS jamais sugeriram um diálogo de grupo-para-grupo". Isso seria o resultado de diferentes visões de mundo, e do fato de que os países BRICS tornaram-se "pontos de veto" contra o Ocidente. Isso corresponde à retórica de estabelecer uma ordem global alternativa:

"Refletindo as grandes diferenças entre os cinco países, a intensificação das relações entre os países BRICS não significa que eles formam sistematicamente um bloco. No entanto, as redes crescentemente densas entre os cinco países estão baseadas em um objetivo comum: avançar o G20 e outras arenas multilaterais como um fórum internacional e contrabalançar o que eles percebem como um mundo multilateral não democrático e injusto, dominado pelo Ocidente. O fenômeno BRICS deveria, portanto, ser visto como refletindo uma mudança geral no equilíbrio internacional de poder com o centro de gravidade movendo da área Euro-Atlântica para a da Ásia-Pacífico, e do Norte para o Sul. (Keukeleire, Mattlin, Hooijmaaijers et al., 2011, p. $1)$ "

As declarações de cúpula dos BRICS não dedicam atenção especial à UE, da mesma forma que a Estratégia Global da UE não menciona os BRICS. Isso novamente aponta para esses dois grupos engajando-se menos no nível multilateral, e mais em tratativas bilaterais. (FREIRE, 2017, p. 193) Assim Gratius (2013, p. 4) escreve que um argumento é o nível de cooperação ou interdependência econômica: "o boom de exportação e de crescimento econômico da China depende altamente da UE (seu principal parceiro comercial), enquanto que 
a China é o segundo mercado de importação e exportação da UE. As exportações russas de petróleo e gás concentram-se na UE e Moscou não é apenas o principal fornecedor de energia de Bruxelas, mas também uma dor de cabeça política importante, particularmente no que se refere a resolver conflitos internacionais tais como o problema com o Irã ou a guerra civil na Síria."

Os BRICS parecem ter cessado de serem vistos pelos formuladores de política da UE como uma constelação vaga de países emergentes que ocasionalmente definem respostas comuns a desafios globais. No entanto, eles certamente ainda não são vistos como um bloco coeso alternativo na cena internacional ${ }^{60}$. Sua unidade e coerência vão continuar a variar de acordo com a área de política em questão. (UJVARI, 2015, p. 4).

Na publicação mais recente que fixa as diretrizes para a política comercial da UE, “Trade for all: towards a more responsible trade and investment policy", de 2015, nota-se a ausência de qualquer referência aos BRICS como grupo. No entanto, o documento enfatiza que, no futuro, a UE terá de melhorar a coerência entre sua abordagem para os países em desenvolvimento nos níveis multilateral, bilateral e unilateral. Em particular, com aqueles países que se graduaram do SGP, reciprocidade quase completa deveria ser esperada nos acordos bilaterais futuros. (DG COMÉRCIO, 2015, p. 30)

No campo do comércio internacional os BRICs tem se mostrado menos coesos do que em outras áreas de relações internacionais. Isso ficou demonstrado, por exemplo, no isolamento da Índia na $9^{a}$ Conferência Ministerial da OMC em Bali em 2013. Ainda assim, a DG Comércio da Comissão publica regularmente estatísticas sobre o câmbio de bens entre a UE e os BRICS

\footnotetext{
${ }^{60}$ Em termos de padrão de comércio, há diferenças significativas entre os países BRICS, o que também dificulta a formulação de uma política inter-regional europeia para essa coalizão.
} 
como um todo. O comitê do Parlamento Europeu para o comércio internacional, por sua parte, apontou em uma resolução adotada em abril de 2013 para a importância de se vincular o poderio econômico crescente dos BRICS ao respeito de princípios democráticos e de boa governança ${ }^{61}$ (UJVARI, 2015)

Nesse sentido, Hoojemeirs (2011, p. 8) argumenta que, tendo em vista a extensão relativamente baixa de coesão de votação entre os BRICS e os Estados-Membros da UE na Assembleia Geral da ONU, o relacionamento entre ambas as partes dificilmente pode ser considerado como um de "parceiros com ideias semelhantes". Os estados-membros da UE agem como um grupo coerente em aproximadamente 70 por cento das resoluções postas em votação, e os países BRIC podem apenas em uma extensão limitada ser vistos como um grupo coerente - portanto o fato que a combinação desses dois blocos de países leva a um baixo grau de coesão de votação não pode realmente ser visto como surpreendente.

${ }^{61}$ Ver: Relatório sobre o Desenvolvimento Mundial 2017: Governança e o Direito. Disponível online:

[https://openknowledge.worldbank.org/bitstream/handle/10986/27986/211119PT.pdf?sequence=9\&is Allowed=y]. Acesso em 13 de fevereiro de 2019. 


\section{Cabos diplomáticos - Wikileaks (2003-2010)}

Corroborando a análise de fontes primárias e literatura secundária, os cabos diplomáticos dos EUA não retratam uma política específica da UE em relação a essa coalizão de países, ou mesmo que os BRICS como grupo tenham sido alvo de negociações ou discussões entre diplomatas americanos e europeus. Igualmente, esse conjunto de dados empíricos reforça a avaliação de estudos anteriores, e da análise documental, que os EUA também não tem uma política específica para os BRICS, ou para a ascensão desse grupo de países. A seguir fazemos uma análise dos poucos telegramas que fazem referência a essas potências emergentes sob a sigla de BRICS, e como se relacionam com a ação externa da UE.

Assim, em um cabo diplomático de 19/02/2010, sobressai-se o aspecto da diversidade dos países BRICS e da falta de coesão entre eles. Um diplomata sênior do Itamaraty enfatiza também a preocupação em relação à China, e à dificuldade de encontrar os interlocutores corretos do governo Chinês:

"Tendo retornado recentemente de uma viagem à China em preparação ao encontro dos BRIC em 15-16 de abril em Brasília, Jaguaribe falou candidamente sobre as dificuldades de se desenvolver uma agenda e uma missão de conjunto para os BRIC. A China, ele percebeu, representava um desafio particular ao Brasil devido às diferentes percepções pelos Chineses a respeito do que um grupo como os BRIC significaria. Jaguaribe enfatizou que a China está muito cautelosa em não fazer o BRIC parecer como um grupo em oposição aos interesses das potências estabelecidas, e como resultado trabalha para fazer a agenda menos do que completamente precisa. A China também é especialmente sensível a preocupações das nações em desenvolvimento que não querem que o BRIC pretenda falar como a voz dos países em desenvolvimento. O Subsecretário também [...] [comentou] que 'Este é um grupo de países muito heterogêneo, com diferentes objetivos, mas o interesse está ali'." 
Igualmente, em um cabo diplomático de 30/10/2008, o embaixador dos EUA em Brasília nota a ambição do Brasil em ser um país forte dos BRIC, e de alcançar um acordo de livre comércio com os EUA ou a UE. Essa avaliação fez parte de um telegrama prévio ao início do "Diálogo de parceria estratégica":

"Nós vemos o Brasil evoluindo em direção a uma nova definição do interesse nacional, à medida que as percepções dos formadores de opinião sobre o lugar do Brasil no mundo, sua importância, e sua habilidade de influenciar evoluem. O Brasil quer ser o melhor dos BRICS, eles querem ser um líder entre os países em desenvolvimento, e eles querem engajar-se com potências como os EUA e a União Europeia em áreas de interesse mútuo (tais como as conversas comerciais $4+1$ ou um APC com a UE), bem como avançar seus interesses bilaterais em fóruns como a OMC. Nós não deveríamos ver essa estratégia em evolução como inerentemente inconsistente. ”

\subsubsection{Resultados}

A ausência de referência ao grupo dos BRICS na EUGS reforça a percepção da inexistência de uma estratégia da UE para a formação de novas constelações de atores na arena internacional, assim a hipótese 1 não passa um teste hoop no que se refere à primeira parte do mecanismo causal. A ênfase em acordos bilaterais parece partir da assunção de que esses acordos podem levar a uma futura multilateralização do sistema mundial de comércio, porém esse processo não necessariamente se observa, e a proliferação de APCs também pode intensificar a fragmentação desse regime.

Igualmente, embora em termos de parcela de mercado os BRICS sejam inferiores à UE (exceto Índia e China), a ação política concertada desses países representa ameaça à pretensão europeia de maior presença e atuação globais (GOMEZ-ARANDA, 2017). De uma perspectiva realista, a UE parece ter tomado nota da relevância desses países como fonte de recursos e 
potencial de mercados. Tendo em vista a recente criação do SEAE e maior coordenação do aparato diplomático europeu com as instituições domésticas da UE, chama a atenção que apenas dois documentos, no período analisado, tenham feito referência aos BRICS (declaração de Catherine Ashton em 2012).

E, mais especificamente no caso da nova chefe da diplomacia europeia desde novembro de 2014, Federica Mogherini, nenhuma das bases de dados da Comissão Europeia dispõe de pronunciamentos oficiais que contenham referência aos BRICS. Embora o período em tela tenha testemunhado uma desaceleração econômica nesses países, o grupo deu passos importantes rumo a uma maior institucionalização da iniciativa, além da criação de novos mecanismos no âmbito do sistema financeiro internacional tal como o NBD (Novo Banco de Desenvolvimento) (ARMIJO, 2018; STUENKEL, 2017). Em síntese, esse conjunto de evidências indica que a hipótese 1 não passa um teste straw-in-the-wind - pois não há discussões sobre a necessidade de adotar uma política comercial específica para os BRICS -, porém passa um teste hoop, no que se refere à terceira parte do mecanismo causal (busca de novos acordos na arena bilateral)

O caso das negociações UE-Brasil parece ser o mais claro, dentre os países BRICS, de uma mudança de ênfase, para maior atenção à dimensão bilateral, conforme ficou evidenciado pela parceria estratégica de 2007 - processo já enfatizado no capítulo anterior (HOLDEN, 2015; MEISSNER, 2016; VAN LOON; 2015). No que se refere ao acordo concluído com a África do Sul, em 2002, embora se trate de um acordo bilateral de comércio, na prática esse é um acordo entre a UE e a SADC, devido à participação Sul-Africana na organização regional.

O acordo UE - África do Sul foi atualizado em 2009, demonstrando o interesse europeu em manter boas relações no nível bilateral com o país líder no continente africano. À medida que os prazos estabelecidos no acordo inicial, para liberalização de setores específicos, são 
alcançados, novos setores da economia sul-africana passam a competir com produtos europeus, e cresce também a integração da África do Sul à economia global.

Conforme mencionado na introdução desta seção do capítulo, a intenção da UE de assinar um APC com a Índia tem sido reafirmada nos últimos anos, porém se tratam de negociações com um parceiro com poder de barganha similar à UE, em função do tamanho do mercado indiano. E adicionalmente, a UE parece ter sido mal-sucedida em compreender a dinâmica regional que caracterizam as relações exteriores da Índia, levando um especialista a criticar a parceria estratégica UE-Índia como "uma não-parceria estratégica" (KAVALSKI, 2016).

Assim, esse conjunto de evidências permite afirmar que a hipótese 2 passa um teste straw-in-the-wind no que se refere à primeira parte do mecanismo causal, e um teste hoop para a segunda etapa. Os documentos estratégicos europeus continuam a priorizar o interregionalismo como princípio de política externa da UE, mesmo embora na prática o bloco tenha feito uso crescente de acordos bilaterais de comércio. Com base nos estudos de Young (2006) e Adriansen (2014) - que realizou entrevistas com funcionários da DG Comércio - verifica-se que os novos acordos preferenciais de comércio da UE estão colocando pressão crescente sobre a capacidade administrativa da UE. Essa peça de evidência permite afirmar que a Hipótese 2 passa um teste smoking-gun.

A Rodada Doha e a crise de 2008/09 evidenciaram um declínio da presença e influência da UE na arena multilateral (GARCIA-DURAN, 2016). Ao mesmo tempo, a União parece ter adaptado sua política comercial no sentido de buscar novos acordos com parceiros tradicionais, ao mesmo tempo que não adotou medidas protecionistas - contrariando a expectativa do momento imediato pós-colapso financeiro (BOLLEN, 2017). Assim, na análise de documentos, 
sobressaem-se as iniciativas europeias para a conclusão de APCs com os EUA (TTIP) e Canadá (CETA).

Da mesma forma, é importante enfatizar que a crise financeira veio somar-se ao desafio externo representado pela ascensão de novas potências econômicas fora da Europa, bem como ao processo de ampliação da UE (inclusão dos países do Leste Europeu) a partir de 2004, e à reestruturação interna a partir da assinatura do Tratado de Lisboa (2007). Em outras palavras, o potencial desafio dos BRICS à política externa europeia é apenas um dos elementos da crise multidimensional que afeta a União Europeia (JEPP, 2015).

Assim, conforme exposto no início da análise deste estudo de caso, a UE tomou nota da ascensão dos BRICS, porém não adotou política específica para o bloco na arena comercial multilateral. A análise de dados de trocas comerciais (fluxo comercial) mostra que os EUA competem por mercados e recursos econômicos com a UE, nestas cinco economias. Portanto, esse conjunto de evidências, tomado em conjunto com o fracasso da tentativa de concluir a rodada Doha em 2011, permite afirmar que a hipótese 3 não passa um teste smoking-gun no que se refere à primeira etapa do mecanismo causal. No entanto, o material empírico analisado permite afirmar que a hipótese 3 passa um teste hoop no que se refere à segunda parte do mecanismo causal, e também um teste smoking-gun na terceira parte do mecanismo causal.

A análise de documentos produzidos pela DG Comércio mostra que a Comissão Europeia dá ênfase a regiões tradicionais na formulação de política comercial, não reservando lugar especial a coalizões como os BRICS. Igualmente, a heterogeneidade do grupo parece corroborar o posicionamento europeu de que a melhor abordagem para esses países reside em parcerias estratégicas ad-hoc, bem como acordos bilaterais de comércio. Nesse campo das relações internacionais, os BRICS também têm se mostrado pouco coesos, conforme mencionamos mais acima. A análise de documentos mostra que a preocupação europeia em 
relação à atuação coesa desse grupo parece mais restrita ao domínio das negociações sobre mudança climática (UJVARI, 2014; COMISSÃO EUROPÉIA, 2015).

A análise do material empírico encontrou evidências de que a UE reconheceu a importância dos BRICS como grupo, e, portanto, a hipótese 4 passa um teste smoking-gun fraco. No entanto, conforme enfatizamos mais acima, não existe um mandato de negociação para um acordo de livre-comércio com o grupo dos BRICS, e pronunciamentos da diplomacia europeia, bem como documentos chave da estratégia externa da UE enfatizam a prioridade reservada para relações no nível bilateral com esses países. Desta forma, a hipótese 4 não passa um teste hoop no que se refere a essa parte do mecanismo causal. A análise do material empírico também permite afirmar que a UE não dispõe de uma política específica para os BRICS na arena comercial, embora tenha buscado assinar acordos na esfera bilateral com esses países. Portanto, a hipótese 4 não passa um teste smoking-gun no que se refere à terceira etapa do mecanismo causal. 


\subsection{Estudo de caso II: UE - GCC (Conselho de cooperação dos países do Golfo)}

Comparado com outros casos investigados nos trabalhos de McCrossan (2014), Meissner (2016) (Mercosul, ASEAN \& CAN) e Schade (2016) as relações UE-GCC parecem ser um caso desviante. Em suas relações inter-regionais com o GCC, a UE tem colocado muito mais ênfase em assuntos políticos (incluindo considerações geopolíticas e de direitos humanos) do que em todos outros acordos comerciais. Assim, Antkiewicz \& Momani (2009) explicam que a motivação da UE para as negociações inter-regionais para um APC com o GCC não está no comércio, mas em interesses geopolíticos e ideacionais. (MEISSNER, 2016, p. 133).

Conforme explicado na introdução a este capítulo, o caso das negociações UE - GCC também demanda explicação adicional devido ao fato de contrariar a expectativa teórica do Realismo Comercial (MEISSNER, 2016; 2017): isto é, a UE manteve o formato inter-regional de negociação, mesmo levando em consideração o baixo índice de coesão dos membros dessa organização regional.

Ademais, conforme McCrossan (2014, p. 27) enfatiza, a formulação de política comercial da UE nessa instância aparenta contradizer a hipótese de que a UE vai recorrer ao bilateralismo sempre que estados membros individuais de seus parceiros inter-regionais concluíram APCs com os EUA. Em 2006, os EUA concluíram acordos bilaterais com o Bahrein e Omã, ambos membros do GCC. E apesar do fato de que as negociações inter-regionais da UE com esse grupo ainda não se provaram bem-sucedidas, não houve reação da parte da UE em termos de buscar seus próprios APCs com esses países 


\section{GCC: histórico e integração regional}

O Conselho de Cooperação para os estados árabes do Golfo é uma organização regional, com seis membros: o Reino do Bahrein, o Estado do Kuwait, o Sultanato de Omã, o Estado do Qatar, o Reino da Arábia Saudita e os Emirados Árabes Unidos. Estabelecida em 1981, seus objetivos são avançar a coordenação, integração e interconexão entre seus membros ${ }^{62}$. (SEAE, 2018)

Abrigando uma população de 51 milhões de pessoas em $2016^{63}$, a região exibe alta heterogeneidade em desenvolvimento socioeconômico. Com um PIB per capita variando de $€ 34,000$ a €54,000, o Qatar, Kuwait, e os Emirados Árabes Unidos são os países mais ricos, ao passo que a Arábia Saudita, Omã e Bahrein são menos ricos com o PIB per capita variando de $€ 12,000$ a $€ 13,000$. O capital humano é mais alto no Bahrein, Kuwait e Qatar, com taxas de alfabetização entre $91 \%$ e $94 \%$, enquanto que nos outros países as taxas de alfabetização são mais baixas. O GCC é bem conhecido por suas reservas de hidrocarbonetos, mas desde sua descoberta e o início da exploração de petróleo nos anos 1970, as reservas diminuíram substancialmente na maioria dos países, o que levou os governos a se engajarem em políticas de diversificação econômica. (AYADI \& GADI, 2014, p. 47)

\footnotetext{
${ }^{62}$ O GCC consiste em um Conselho Supremo, um Conselho Ministerial, e um Secretariado Geral. O Conselho Supremo é composto pelos governantes dos estados membros e serve como a autoridade mais alta de tomada de decisão dentro do GCC. O Conselho Ministerial do GCC, composto pelos ministros de relações exteriores dos estados membros, encontra-se trimestralmente. Cada membro também tem a opção de convocar uma sessão extraordinária de qualquer conselho, desde que outro membro do GCC se junte à convocação. Nessas reuniões, cada Estado-Membro detém um único voto. Há uma preferência forte pelo consenso, mas as decisões são tomadas por maioria quando necessário. (MARTINI ET AL. 2016, p. 20)

63 Fonte: Gulf Research Center (2016). http://gulfmigration.eu/gcc-total-population-percentagenationals-foreign-nationals-gcc-countries-national-statistics-2010-2016-numbers/
} 
Os motivos de segurança foram a força impulsionadora da criação do GCC. No momento posterior à primeira Guerra do Golfo entre o Irã e Iraque, os países da península Arábica decidiram iniciar um movimento em direção à integração regional com vistas a lidar com possíveis ameaças à segurança. Os países na região compartilham muitas características, mas apesar de suas comunalidades, algumas diferenças importantes existem. Por exemplo, o Bahrein e o Kuwait têm sistemas políticos com algum grau de abertura, com eleições parlamentares e uma constituição escrita, ao passo que a Arábia Saudita se parece mais com uma monarquia absoluta (AYADI \& GADI, 2014, p. 48)

Vários fatores podem ser destacados para explicar por que o progresso na integração regional tem sido lento. Como produtores de petróleo e hidrocarbonetos, os países do GCC são competidores $^{64}$, o que torna a necessária coordenação de políticas industriais na região difícil. Essa similaridade nas estruturas de produção traduz-se em taxas muito baixas de comércio intraregional; o comércio intra-GCC (importações e exportações) foi em média de 7 \% entre 1995 e 2011, comparado com 63\% para a UE e 23\% para os países do ASEAN. As economias do GCC aparentam ser altamente dominadas pelo Estado, com os governos detendo parcelas importantes dos setores industrial e de serviços. Por exemplo, os governos do GCC retêm participação significativa na propriedade dos setores de hidrocarbonetos do país, e bancos estatais totalizaram uma média de $22 \%$ dos totais de ativos bancários na região entre 2003 e 2011 , comparado a 12\% na UE15. (AYADI \& GADI, 2014, p. 48)

${ }^{64}$ Quatro dos estados membros do GCC são considerados grandes membros da OPEP, incluindo a Arábia Saudita, os EAU, o Qatar e o Kuwait. A Arábia Saudita e os EAU têm reservas maiores de petróleo e populações menores, com necessidades urgentes de diversificar suas economias, movendose em direção a serviços como o turismo, finanças, reexportações e tecnologia da informação (EISSA, 2014, p. 346). 


\section{Histórico da cooperação UE - GCC}

Os desequilíbrios básicos nas relações UE-GCC já foram bem documentados. Não existe um quadro institucional de densidade comparável à Parceria Euro-Mediterrânea; tanto a UE, como o GCC são marcados por divisões incoerentes de competências políticas; iniciativas bilaterais dos estados membros prevalecem no domínio da segurança; e as rivalidades regionais próprias do Golfo tem complicado esforços para aprofundar laços. Isso reforça um subtema de maior ressonância geral e comparativa: o Golfo é uma região em que o declínio relativo da presença e influência europeias está fortemente aparente. (YOUNGS, 2009, p. 1)

Embora o GCC tenha privilegiado os EUA como parceiro internacional graças ao engajamento desse país na região desde a descoberta de hidrocarbonetos, a região tem atraído a atenção dos formuladores de política da UE desde os anos 1970, como resultado de um conjunto de interesses geopolíticos e comerciais. A primeira iniciativa estruturando relações entre países da UE e os países do GCC remonta a 1974, quando a França pressionou pelo lançamento do diálogo Euro-Árabe, em seguida à Guerra Árabe-Israelense de 1973 e à primeira crise do petróleo. A iniciativa não visou os países do GCC exclusivamente, mas buscou estabelecer um diálogo permanente entre os países europeus e membros da Liga Árabe. Eventualmente, a iniciativa entrou em colapso em 1989 sem nenhum resultado significativo em termos de cooperação aprofundada ou abrangente. (COLOMBO \& COMMITIERI, 2014, p. 52)

À época da conclusão do Acordo de Cooperação, em 1988, as motivações dos países da UE eram bem claras. Os países do GCC eram fornecedores importantes de hidrocarbonetos e um mercado de exportação importante para as economias europeias. Além de sua dimensão econômica, o acordo também tinha uma dimensão política menor, em que a UE via o grupamento do GCC como um ator importante para a promoção da estabilidade na região. A fim de alcançar esse objetivo, foi estabelecida cooperação em um conjunto amplo de áreas: 
economia e comércio, agricultura e pesca, indústria, energia, ciência e tecnologia, investimento e meio-ambiente. Atualmente, a motivação para ter relações próximas com os países do GCC é diferente e talvez mais forte, tendo em vista que as relações de comércio e investimento aumentaram devido ao fato de que a região abriga os maiores fundos de investimento soberanos, que emergiram desde 2008 como fornecedores importantes de finanças de emergência para instituições financeiras abaladas da UE. (COLOMBO \& COMMITIERI, 2014, p. 55)

A UE e o GCC têm relações políticas limitadas e parceiros comerciais e de investimento bilaterais estáveis, embora países emergentes - principalmente a China - estejam crescentemente competindo com a UE na região. No fim dos anos 1980, a UE e o GCC iniciaram negociações para um APC que teria sido o primeiro acordo comercial de região para região já concluído. O acordo buscou reforçar a integração entre ambas regiões e foi além de integração superficial e retirada de tarifas, para tratar de questões como liberalização de comércio em serviços, regulamentações de investimento e regras de compras governamentais. Apesar do escopo amplo do acordo, as partes falharam em chegar a um consenso, resultando na falha das negociações ${ }^{65}$. Isso demanda uma avaliação das motivações da UE e do GCC para o acordo proposto e seus benefícios potenciais ${ }^{66}$. (COLOMBO \& COMITTIERI, 2014, p. 75).

\footnotetext{
${ }^{65}$ Três principais razões podem ser apontadas para a falha em concluir as negociações, quando em 2008 o GCC as suspendeu unilateralmente: 1) O lobby petroquímico da UE lutou ferozmente contra a liberalização do comércio, resultando no bloqueio dos governos europeus ao acesso livre de tarifas para os produtos do Golfo por muitos anos; 2) As cláusulas de direitos humanos e migração ilegal embutidas no acordo foram rejeitadas pelos estados do GCC, que afirmaram que Bruxelas estava trazendo questões que não tinham nada a ver com comércio à mesa. 3) os países do GCC estavam relutantes em atender às demandas da UE para liberalizar serviços e compras governamentais. (AYADI \& GADI, 2014, p. 82)

${ }^{66}$ Há claramente um número de áreas que a UE tem expertise e experiência significativas que podem adicionar grande valor aos países do GCC à medida que eles buscam reforma. Em adição às relações tradicionais e de negócios existentes - defesa, infraestrutura, construção - as economias do Golfo estão procurando por um aumento no investimento no setor privado, por meio de parcerias público-privadas e estruturas "build-own-operate". (CORNOCK, 2017, p. 12)
} 
Igualmente, a natureza muito diferente das duas organizações tem prejudicado as relações UE-GCC. Se a UE é uma entidade com poderes supranacionais, o GCC é uma instituição intergovernamental. No contexto das negociações para o APC, isso tem atrasado a habilidade de concluir o contrato. Uma pré-condição para o mandato de negociação da UE de 1991 foi o estabelecimento de uma união aduaneira do GCC, tendo em vista que isso evitaria desvio de comércio dos países do GCC com taxas aduaneiras mais altas para países com taxas mais baixas. (ESCRIBANO-FRACES, 2005, p. 10). Dado o grau incipiente de integração do GCC, eles precisaram de tempo para atender essa pré-condição. Em seguida ao comprometimento do GCC de estabelecer uma união aduaneira, a UE adotou um mandato mais amplo para o APC adicionando comércio em serviços, compras governamentais e direitos de propriedade intelectual. (KOSTADINOVA, 2013, p. 3).

No período mais recente, as relações comerciais e de investimento tem prosperado, impulsionadas pelos altos preços do petróleo e os imperativos de desenvolvimento dos países do Golfo. No entanto, a crise econômica e financeira de 2008 levou a uma interrupção do desenvolvimento das relações comerciais UE-GCC; à medida que as economias emergentes dos BRICs se provaram mais resilientes à turbulência financeira, eles ultrapassaram a UE e em 2009-2010 tornaram-se os maiores fornecedores do Golfo e mercado de exportação primária. A imunidade dos mercados emergentes à turbulência financeira tem influenciado os números relativos ao crescimento comercial; entre 1995 e 2011, a média composta de taxa de crescimento das exportações do GCC para os BRICs totalizou 21\%, comparado a $12 \%$ para a UE e 14\% para o mundo inteiro (AYADI \& GADI, 2014, p. 54) 
Atualmente não há nenhum acordo de livre comércio ou de associação entre a UE e o $\mathrm{GCC}^{67}$, e as negociações têm estado dormentes a esse respeito por algum tempo. De acordo com a Comissão, um “diálogo informal mais estruturado" sobre comércio e investimento entre a UE e o GCC foi relançado em maio de 2017. No entanto, ainda não há notícias de quando esse diálogo poderia mover-se adiante em uma base mais formal. Tendo em vista que a Associação Europeia de Livre Comércio tem um acordo de livre comércio com o GCC desde 2014, o atraso adicional nessa área, conforme enfatizou o comitê INTA ${ }^{68}$, sugere que "uma oportunidade importante está atualmente sendo perdida". (PARLAMENTO EUROPEU, 2017, p. 19)

\subsubsection{Coesão}

Existe uma literatura bastante extensa sobre o Golfo Árabe, particularmente a partir de uma perspectiva de segurança, mas a coesão do GCC é uma dimensão sub-explorada em análises regionais. (MARTINI, 2016, p. 2). Compreender o escopo e os limites da coesão do GCC é crucial para interpretar a significância dos desenvolvimentos dentro do bloco. Conforme Martini et al. (2016, p.11) enfatizam, há uma tendência de alguns observadores do GCC de inflar a importância de desenvolvimentos que estão dentro da norma e da natureza cíclica da coesão do GCC. Um estado membro particular, encontrando-se em divergência com a visão majoritária dentro do GCC, como tanto Doha, como Muscat o fizeram recentemente, é uma característica esperada da política do Golfo Árabe. Os seis estados tendem a dispersar-se, reunir-se novamente, e parear-se. (MARTINI ET AL., 2016, p.11).

\footnotetext{
${ }^{67}$ No início de fevereiro de 2019 a UE chegou a um entendimento com o Qatar para um acordo de aviação civil (céus abertos), que deve ser assinado ainda este ano. Esse acordo é o primeiro entre o bloco europeu e um país do GCC (REUTERS, 2019)

${ }^{68}$ Comitê do Parlamento Europeu para o comércio internacional.
} 
A principal razão que faz esses países manterem-se unidos é sua crença na estabilidade e calamidade com o ambiente político regional perigoso que eles enfrentam, incluindo no passado os agressivos Irã e Iraque e as revoluções da primavera Árabe. De fato, o GCC alcançou um grau alto de integração de capital, serviços, bens e mercados de trabalho, e em termos de padronização regulatória, está bem à frente de seus vizinhos. Mais recentemente, também endureceu sua cooperação em assuntos internos de segurança (EISSA, 2014, p. 340)

A ênfase da UE em questões políticas pode ter sido uma razão para sua persecução continuada de inter-regionalismo, apesar do baixo grau de coesão no GCC. Embora Echague (2007) apontem que a UE tem mantido uma política reativa em relação ao GCC, a insistência europeia no inter-regionalismo não tem paralelo com as características da região do Golfo. Ao invés de ser coeso, o GCC não é um bloco único (COLOMBO \& COMMITTIERI, 2013, p. 25), mas sim marcado por tensões políticas e institucionais. Dentro do GCC, os estados membros não têm experiência com negociações inter-regionais; eles não têm instituições supranacionais, nem posições comuns em relações exteriores (ECHAGUE, 2007, p. 9). Essas tensões políticas e institucionais também têm influenciado as negociações de comércio, quando os membros individuais do GCC assinaram APCs bilaterais com os EUA (ECHAGUE, 2007, p. 9). Nesse sentido, a política inter-regional da UE tem negligenciado a realidade regional do Golfo. (MEISSNER, 2016, p. 133)

Apesar de fortes interesses na cooperação, os estados do GCC frequentemente precisam de uma crise para romper a barreira das sensitividades soberanas. Essas crises, tais como a Guerra do Golfo de 1990-1991 ou a revolta de 2011 no Bahrein, de fato levam a períodos de coesão mais forte no GCC em que os seis estados aproximam-se para fazer face a ameaças externas e proteger seus sistemas monárquicos da oposição interna. Mas essa cooperação não é sustentada, e o desenvolvimento institucional do GCC, embora pleno de projetos de alto perfil, 
tal como a criação da PSF (Peninsula Shield Force) ${ }^{69}$, e um mercado comum, frequentemente exageram o nível de integração verdadeira. (MARTINI ET AL., 2016, p. 23)

Assim, sintetizando as informações empíricas relativas ao período de 2003-2011, o GCC manteve um índice de coesão baixo. Ressalta-se que a criação da União Aduaneira em 2003 representou avanço significativo em termos de construção de instituições supranacionais, bem como no que se refere ao aprofundamento dessas instituições. No que se refere ao comércio intra-GCC, apenas Kuwait e Omã apresentaram modesto crescimento nas exportações e importações de membros da organização regional, porém em termos do total do bloco (taxa de 19\%), o valor está pouco abaixo do ASEAN por exemplo. Assim o GCC pontua nesse item do índice de coesão

A partir dos dados compilados por Martini et al. (2016), é possível identificar uma tendência diferente no que se refere ao fluxo de investimentos intra-GCC, que aumentou significativamente no período de 2000-2008 (\$30 Bilhões), em comparação com os \$3,6 bilhões do período de 1990-2003. No entanto, esses investimentos mantiveram-se concentrados na indústria do petróleo. Em 2005, o GCC adotou uma política comercial externa comum - o que indica uma convergência maior no que se refere à substância do comércio exterior - e no que se refere a disputas comerciais intra-GCC, nenhum caso chegou à $\mathrm{OMC}$ no período em tela (OMC, 2019). Porém, a ideia de criar uma moeda comum não teve progresso, quando em 2006 o Omã decidiu abandonar a iniciativa, a quem se seguiu os EAU, após anunciar um plano para a criação de um Banco Central em Riad ${ }^{70}$ (DUDLEY, 2018).

\footnotetext{
${ }^{69}$ A Força do Escudo da Península foi criada em 1984, a fim de responder a ameaças externas e aos desafios colocados pela localização geográfica. Atualmente, o conflito Árabe-Israelense e as questões em torno do programa nuclear iraniano representam as maiores ameaças no que se refere à competência militar da Força. (ALSIRI, 2015)

${ }^{70}$ Artigo da Revista Forbes, disponível em https://www.forbes.com/sites/dominicdudley/2018/07/25/istime-running-out-for-the-gulf-cooperation-council/\#52c654db56b8
} 
Tabela 14: Coesão do GCC (2003-2011)

\begin{tabular}{|c|c|c|}
\hline Coesão & Indicador & Pontuação \\
\hline \multirow{6}{*}{$\begin{array}{l}\text { Política } \\
\text { Intra-Regional }\end{array}$} & Número de disputas comerciais (1) & \\
\hline & Intensidade de disputas comerciais (2) & \\
\hline & Solução de disputas comerciais (3) & \\
\hline & Instituições supranacionais (4) & $\mathrm{X}$ \\
\hline & Aprofundamento de instituições (5) & $\mathrm{X}$ \\
\hline & Alargamento de instituições (6) & \\
\hline \multirow[t]{5}{*}{$\begin{array}{l}\text { Política } \\
\text { Extra-regional }\end{array}$} & $\begin{array}{l}\text { Unidade em instituições internacionais } \\
\text { (7) }\end{array}$ & $\mathrm{X}$ \\
\hline & Unidade em áreas não-reguladas (8) & \\
\hline & Unidade em cúpulas presidenciais (9) & \\
\hline & Prioridade de parceiro de negociação (10) & \\
\hline & Prioridade de matéria de negociação (11) & \\
\hline \multirow{4}{*}{$\begin{array}{l}\text { Assuntos } \\
\text { Econômicos }\end{array}$} & Convergência de comércio (12) & $\mathrm{X}$ \\
\hline & Investimento por parceiro (13) & $\mathrm{X}$ \\
\hline & Tipo de comércio (14) & \\
\hline & Tipo de investimento (15) & \\
\hline Soma & & 5 \\
\hline
\end{tabular}

Porém, no período mais recente, duas crises $^{71}$ (de 2014 e de 2017) não levaram a maior coesão e quase puseram fim ao GCC - a organização considerada uma das mais estáveis da região MENA (Oriente Médio e Norte da África). Bianco \& Stenfield (2018, p. 613) argumentam que haveria uma conexão entre os eventos de 2011 essas crises, e que esses

${ }^{71}$ Em 2014, o UAE, a Arábia Saudita e o Bahrein retiraram seus embaixadores do Qatar em protesto à política externa desse país. (MARTINI ET AL., 2016). Em 2017, a Arábia Saudita liderou três países em um boicote econômico, político e diplomático contra o Qatar. 
desenvolvimentos demonstraram que as percepções de ameaças são crescentemente divergentes no nível dos governos do GCC. Ademais, as divergências intra-bloco seriam enraizadas tanto em fatores domésticos tangíveis, tais como clivagens profundas no tecido nacional, ou dinâmicas sócio-econômicas disfuncionais e fatores intangíveis, tais como a memória coletiva do país, sua insegurança ontológica e mesmo as percepções individuais dos líderes.

Assim, ao longo do período mais recente, não houve alargamento significativo de instituições supranacionais, e o nível de soberania concedido a essas instituições permaneceu baixo. No entanto, a solução para a crise de 2014 pode ser vista como "um pequeno passo no desenvolvimento institucional do bloco" (MARTINI ET AL., 2016). A União Aduaneira criada em 2003 entrou em vigor em $1^{\circ}$ de janeiro de 2015, após um longo período de impasse - e poderá significar uma melhor no comércio interno e exterior (EUI, 2015). O mercado comum resultante é semelhante àquele existente na UE - isto é, não há tarifa intra-Golfo.

Semelhantemente ao período precedente, o comércio intra-GCC (Figura 8) apresentou uma elevação modesta no período de 2012-2015, principalmente em função do desempenho do Bahrein, Omã e Arábia Saudita. O número de disputas comerciais permanece muito baixo para o período, em sua maior parte estando apenas na etapa de consultas na OMC, porém o caso do Qatar contra os UAE, iniciado em julho de 2017, entrou na fase de painel em setembro de 2018, evidenciando a incapacidade do GCC de resolver a disputa em nível supranacional.

Em 2016, o bloco deu início a uma medida de salvaguarda na OMC, para importações de ferro e aço, a partir da iniciativa da Arábia Saudita em nome de todos os membros do GCC. As restrições passaram a vigorar em maio de 2018 e deverão inicialmente totalizar \$169 bilhões de dólares, no entanto estão isentos das medidas os países em desenvolvimento. Nesse sentido, houve algum grau de coesão dos países do bloco no que se refere ao comércio exterior - no contexto das medidas anunciadas por Donald Trump de elevar as tarifas de importação de aço nos EUA. 
Figura 7 : Fluxo e equilibrio comercial entre a UE e o GCC

Total goods: EU Trade flows and balance, annual data 2007 - 2017

Source Eurostat Comext - Statistical regime 4

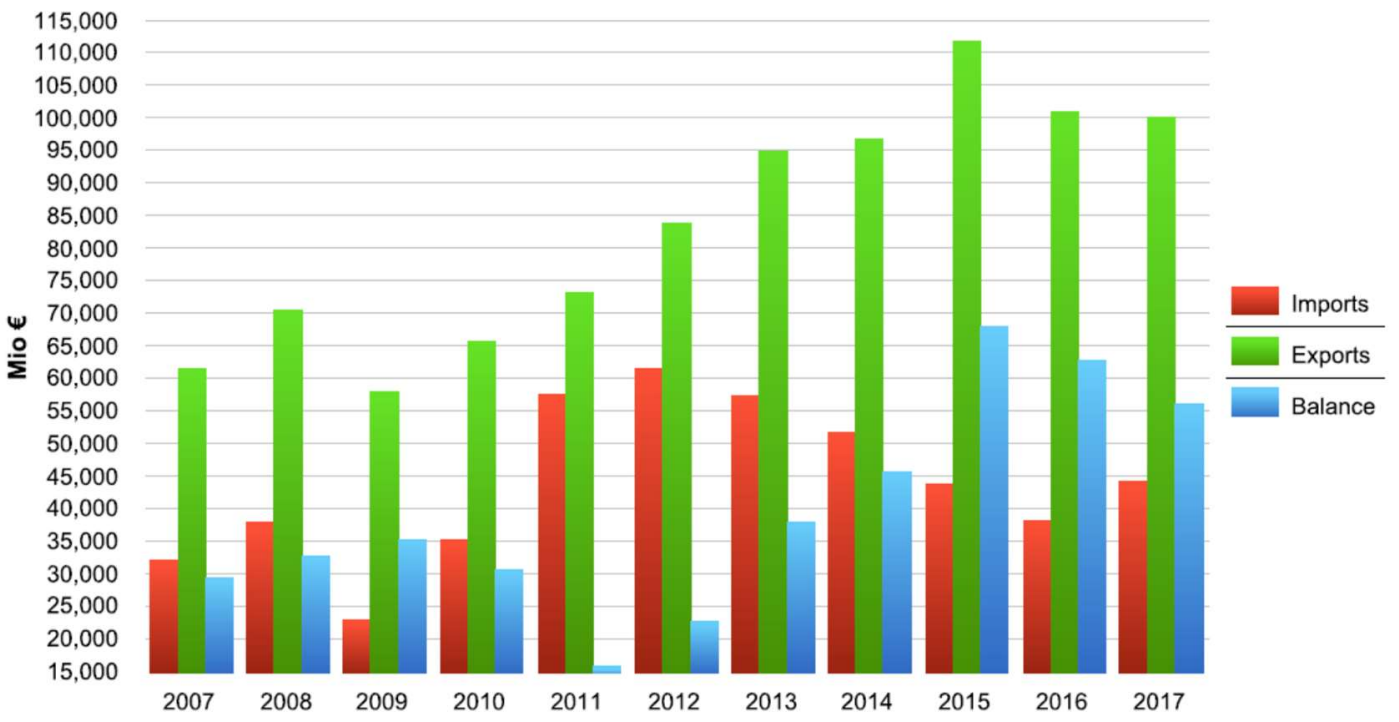

Fonte: Comissão Europeia (2018) 
As relações comerciais da UE com o GCC cresceram de forma constante no período (2012-2017), e atualmente gera um superávit anual de mais de 60 bilhões de euros, de acordo com números da Comissão Europeia, e conforme fica evidenciado a partir da figura 8. No entanto, a maior parte das exportações europeias são fortemente concentradas - mais de 90 por cento - em bens industriais, incluindo usinas de energia, trilhos e aeronaves. Todas essas áreas são de investimento substancial para um número de países do GCC, e é encorajador que firmas europeias continuem a competir bem nessas áreas com rivais na Ásia e na América. No entanto, essa concentração pesada na indústria também pode refletir uma oportunidade perdida para o setor de serviços da Europa. (PARLAMENTO EUROPEU, 2017, p. 19) 
Tabela 15: Coesão do GCC (2011-2018)

\begin{tabular}{|c|c|c|}
\hline Coesão & Indicador & Pontuação \\
\hline \multirow{6}{*}{$\begin{array}{l}\text { Política } \\
\text { Intra-Regional }\end{array}$} & Número de disputas comerciais (1) & \\
\hline & Intensidade de disputas comerciais (2) & \\
\hline & Solução de disputas comerciais (3) & \\
\hline & Instituições supranacionais (4) & $\mathrm{X}$ \\
\hline & Aprofundamento de instituições (5) & $X$ \\
\hline & Alargamento de instituições (6) & \\
\hline \multirow{5}{*}{$\begin{array}{l}\text { Política } \\
\text { Extra-regional }\end{array}$} & $\begin{array}{l}\text { Unidade em instituições internacionais } \\
\text { (7) }\end{array}$ & \\
\hline & Unidade em áreas não-reguladas (8) & \\
\hline & Unidade em cúpulas presidenciais (9) & \\
\hline & Prioridade de parceiro de negociação (10) & \\
\hline & Prioridade de matéria de negociação (11) & \\
\hline \multirow{4}{*}{$\begin{array}{l}\text { Assuntos } \\
\text { Econômicos }\end{array}$} & Convergência de comércio (12) & \\
\hline & Investimento por parceiro (13) & \\
\hline & Tipo de comércio (14) & \\
\hline & Tipo de investimento (15) & \\
\hline Soma & & 2 \\
\hline
\end{tabular}


Figura 8: Comércio intra-GCC (1990-2015)

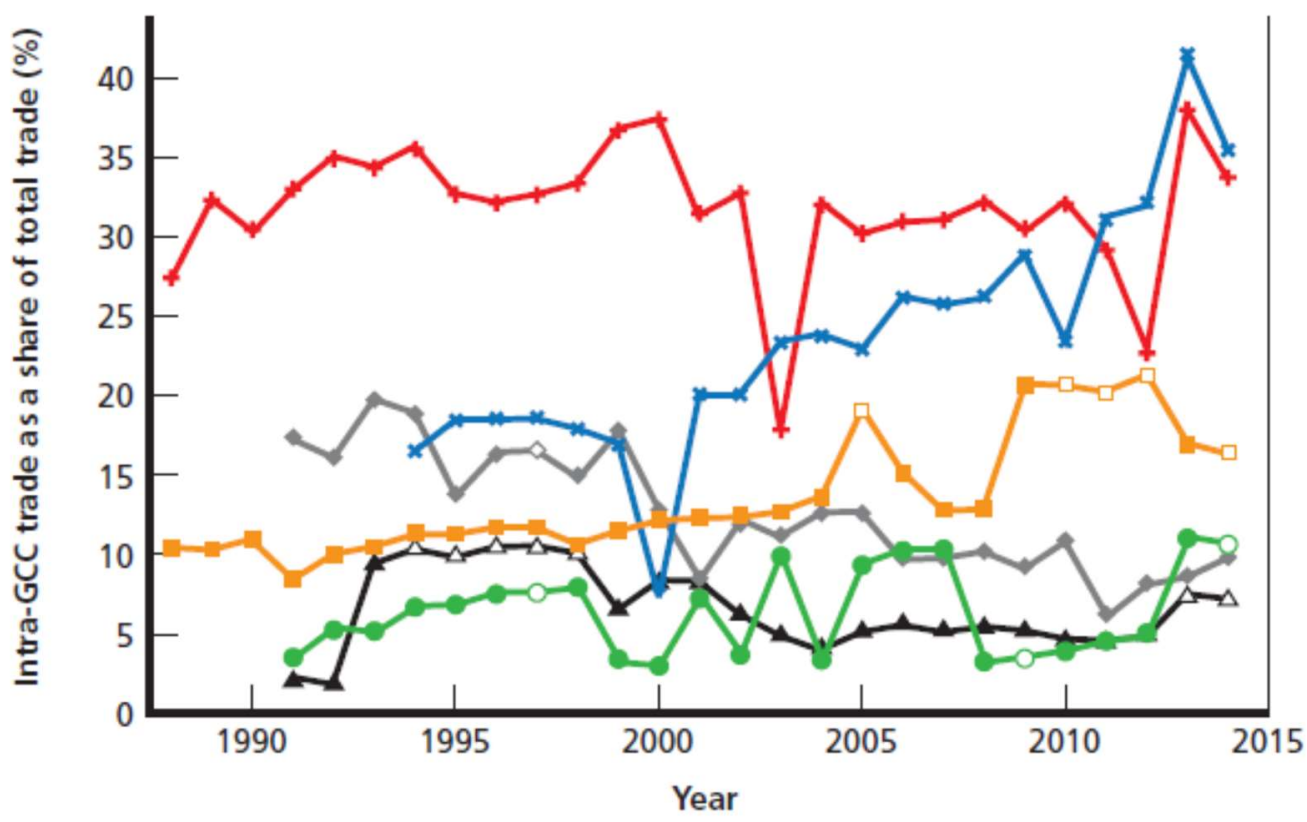

\begin{tabular}{|c|c|}
\hline B_- Bahrain & —- Kuwait \\
\hline
\end{tabular}

Fonte: Martini et al. (2016, p. 21) 


\subsubsection{Competição com atores rivais}

Ao abordar o GCC por meio de negociações de comércio, a UE tem reagido a seus atores rivais: os EUA, a China e também o Japão. Inicialmente, a UE percebia a região do Golfo como uma esfera americana de influência, dadas as relações de segurança dos EUA com alguns países do Golfo. Portanto, a UE passou a focar-se em "low politics" - economia - ao invés de "high politics" ao lidar com o GCC (ECHAGUE, 2007, p.1). Ao usar negociações inter-regionais de comércio como um meio, a UE tentou formar uma aliança geopolítica com o GCC a fim de contrabalançar a influência americana na região (ANTKIEWICZ \& MOMANI, 2009, p. 17). Em 2004, os EUA ${ }^{72}$, a China e o Japão também começaram a fortalecer relações comerciais com os estados membros do GCC, o que intensificou o desejo da UE de concluir um APC com a região do Golfo (COLOMBO \& COMMITTIERI, 2013, p.8).

Assim, a UE tentou diversos formatos inter-regionais a fim de avançar as negociações, tais como encontros anuais de conselho e comitê, contatos informais, e um "instrumento de parceria" para tratar assuntos econômicos, ao mesmo tempo em que se manteve fortemente comprometida com o objetivo de um APC (COMISSÃO, 2017). Portanto as relações interregionais da UE com o GCC podem ser vistas como uma resposta à dinâmica em mudança do engajamento da América e da Ásia na região (Baabood, 2015) (MEISSNER, 2017, p. 11)

\footnotetext{
${ }^{72} \mathrm{Na}$ dimensão econômica, os EUA podem explorar iniciativas com o GCC sem o mesmo nível de bagagem que existe nos domínios de segurança e política. O engajamento econômico com o Golfo não inflama as mesmas sensitividades que a cooperação em segurança, que frequentemente carregam custos políticos domésticos para os líderes do Golfo Árabe. E embora a parcela americana da economia global esteja declinando, os EUA continuam a ser um mercado de consumo atrativo, um líder em inovação e em certa medida uma força estabilizadora em uma era de volatilidade global. (MARTINI ET AL., 2016, p. 69)
} 
Os EUA assinaram acordos bilaterais com Bahrein e Omã em 2006. Esses acordos não provocaram uma demanda forte de firmas e produtores europeus para que a UE buscasse acordos defensivos (MCCROSSAN, 2014, p. 27). O comércio entre a UE e esses países é majoritariamente baseado na importação de petróleo e produtos químicos, e na exportação de maquinário e equipamento de transporte. O comércio de petróleo foi excluído das negociações e, adicionalmente, uma larga parcela das exportações da UE para o GCC já são isentas de tarifas. Assim, os acordos comerciais dos EUA com Omã e Bahrein não representaram uma ameaça grande de desvio de comércio.

A crise financeira elevou o perfil internacional em ascensão do Golfo. Anteriormente ao aprofundamento da crise, no fim de 2008, as economias do GCC tinham triplicado de tamanho ao longo dos cinco anos anteriores. O apoio do Golfo tem sido buscado para a reinjeção de liquidez de curto-prazo nas economias europeias, de tal forma que a Autoridade de Investimento de Abu Dhabi passou a deter uma parcela de 6 bilhões de dólares no banco Barclays. No entanto, nenhum desses eventos foi suficiente para re-energizar as relações UEGCC mais amplas (YOUNGS, 2009, p. 1) 
O comércio dos EUA com o golfo é mais equilibrado do que o da UE. Em 2016, o déficit foi de apenas 2 bilhões de dólares. Por exemplo em 2016 os EUA importaram aproximadamente 15 bilhões de bens da Arábia Saudita, principalmente petróleo, mas também alguns fertilizantes e produtos químicos. A Arábia Saudita, por sua parte, importou 17 bilhões de dólares de produtos muito diversificados dos EUA, incluindo cerca de 2,5 bilhões em equipamentos militares (Escritório de recenseamento dos EUA, 2017, Comércio Exterior). Uma das principais razões para esse comércio mais equilibrado deve-se ao declínio muito rápido nas importações americanas de óleo cru da Arábia Saudita e do resto do Golfo ${ }^{73}$. O declínio nas importações de petróleo é devido ao grande aumento na produção petroleira dos EUA, que hoje está fazendo os EUA um exportador líquido de hidrocarbonetos (PARLAMENTO EUROPEU, 2017, p. 40)

Em última instância, contudo, o quase-equilíbrio da balança comercial da Arábia Saudita com os EUA aponta para o fato de que a parcela de mercado dos EUA no Golfo declinou no Reino, em relação à UE e o Extremo Oriente. Isso porque a competição da UE no Golfo é principalmente com os países dessa última região, em especial com a China, que é agora o principal parceiro comercial da Arábia Saudita e principal comprador de óleo cru. Em anos recentes, o comércio entre os países do GCC e a China cresceu de forma acelerada, impulsionado pela demanda chinesa por recursos de hidrocarbonetos e um aumento no valor agregado de suas exportações. Apesar deste aumento, a UE ainda permanece como um parceiro importante para o GCC, mas há a perspectiva de competição crescente das exportações chinesas

\footnotetext{
${ }^{73}$ Os EUA ainda são um parceiro importante. Seu comércio com o Golfo é quase equilibrado, principalmente porque os EUA não mais importam muito petróleo e vendem programas armamentistas mais sofisticados para os Emirados Árabes Unidos e Arábia Saudita. No entanto, muito embora os EUA ainda importem/exportem aproximadamente $\$ 18$ bilhões/ano, eles ainda estão perdendo parcela de mercado de importações para a UE. Adicionalmente, tanto os EUA e a UE estão sentindo competição forte do extremo oriente (Cihna, Japão, Coréia), que como um grupo crescentemente dominam o comércio e investimentos na região. (SEZNEC, 2017, p. 32)
} 
com aquelas da UE (AYADI \& GADI, 2014, p. 57). Ademais, a competição com os BRICS também tem crescido em produtos manufaturados intensivos em conhecimento ${ }^{74}$.

Figura 9: Importações da China provenientes dos países do GCC (2003-2011)

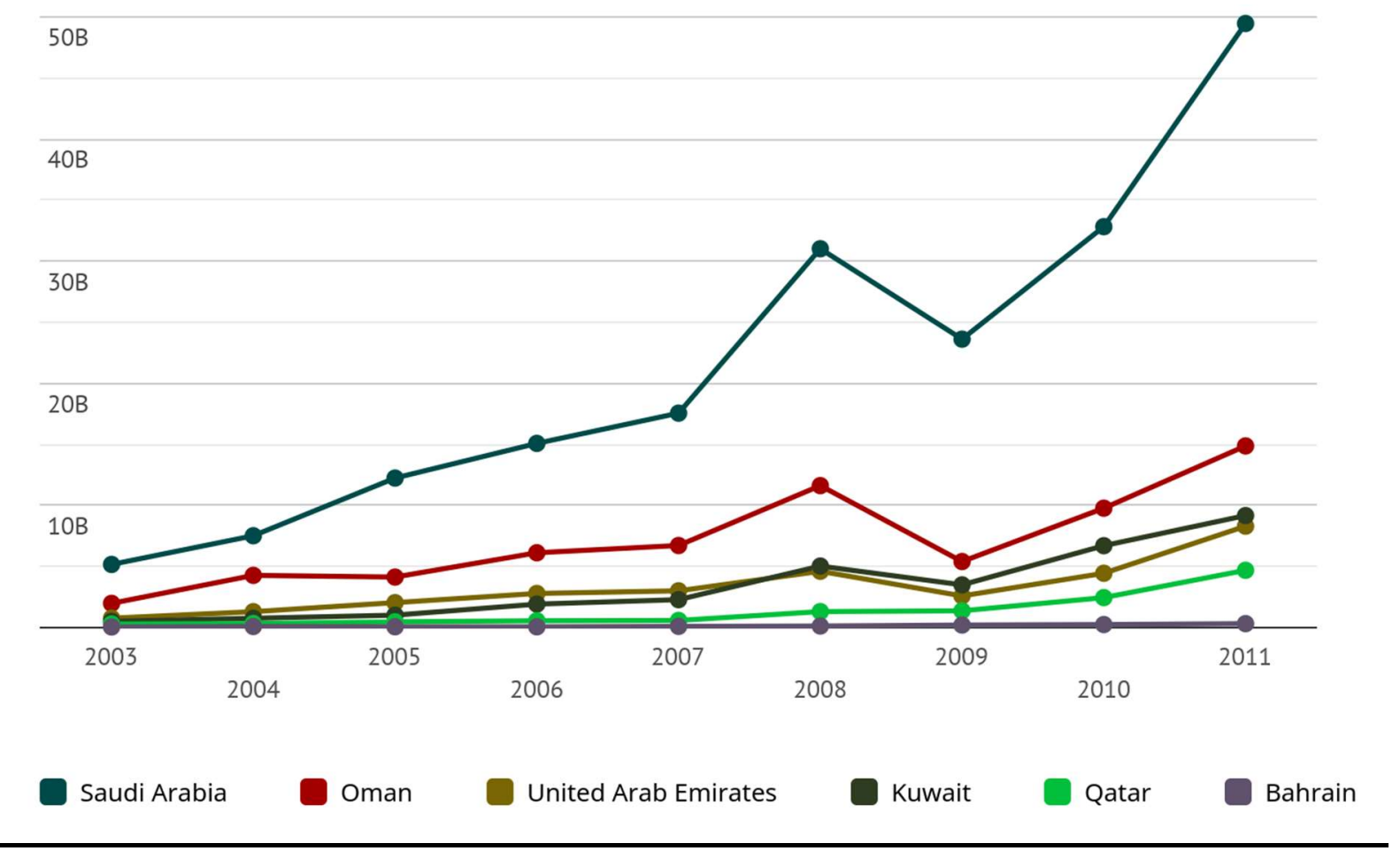

Fonte: Uncomtrade \& Trendeconomy.com (2019)

${ }^{74}$ George Cafiero e Daniel Wagner, "What the Gulf States Think of "One Belt, One Road" The Diplomat, 24 de Maio de 2017. 


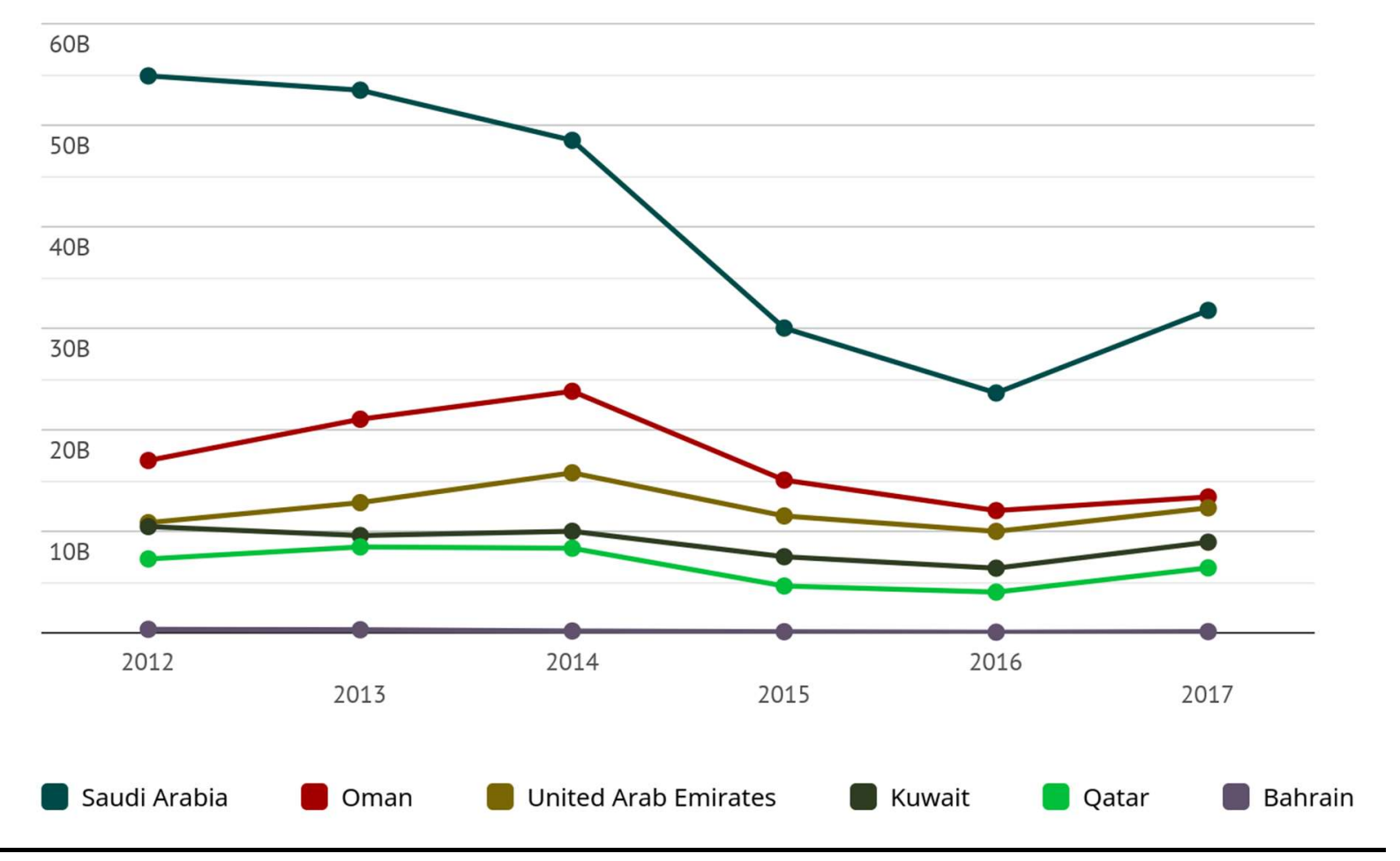

Fonte: Uncomtrade \& Trendeconomy.com (2019)

\subsubsection{Nexo entre política externa e política comercial}

A literatura sobre as relações UE-GCC aponta que a motivação da Europa para um acordo inter-regional reside em interesses geopolíticos ao invés de econômicos (ANTKIEWICZ \& MOMANI, 2009). Em suas negociações inter-regionais com o GCC, a UE reforçou a conexão entre comércio e segurança ao usar benefícios potenciais para os países do Golfo como uma ferramenta para consolidar reformas políticas e estabilizar a região (idem, 2009). No comunicado conjunto da UE com o GCC, por exemplo, os dois parceiros priorizaram discutir tópicos de segurança e questões de direitos humanos ao invés da dimensão comercial da relação. Em particular desde a invasão de 2003 ao Iraque, a UE tem focado-se em segurança 
em sua agenda com a região do Golfo, e tentado estabilizar a paz e segurança ${ }^{75}$ (ANTKIEWICZ \& MOMANI, 2009; DEMMELHUBER \& KAUNERT, 2014; MEISSNER 2017, p. 12)

Embora as negociações para um APC tenham iniciado-se em 1990, imediatamente após a assinatura do Acordo de Cooperação, as perspectivas para um APC de região-para-região apenas se tornaram realistas em 2003, quando o GCC se tornou uma união aduaneira. O ritmo de negociações acelerou-se em 2007 e havia expectativas de que uma conclusão seria alcançada em 2008, à luz do entusiasmo pelas repercussões potencialmente positivas do acordo sobre cooperação política e de segurança entre as duas regiões. No entanto, isso não aconteceu e as negociações foram interrompidas pelo GCC em dezembro de 2008, embora contatos informais entre os negociadores tenham continuado a acontecer desde então. (COLOMBO, 2017, p. 65)

Algumas das transformações em curso na arena internacional e dentro da UE tem levado a um aumento das interações, ou tem o potencial de facilitar uma cooperação UE-CCG maior (por exemplo, uma posição financeira mais fortalecida do CCG vis-à-vis a UE poderia facilitar a conclusão bem-sucedida do APC). No entanto, levando em consideração a incerteza relativa aos resultados de longo prazo desses desenvolvimentos e sua natureza estrutural, é importante manter cautela sobre prognósticos positivos para as relações UE-CCG (KOSTADINOVA, 2013, p. 14). E, diferentemente de outros casos de negociações inter-regionais (por exemplo CAN e ASEAN), no caso do CCG os meios das negociações da UE estiveram acoplados ao interesse de política externa de ter um acordo inter-regional (MEISSNER, 2017, p. 13).

\footnotetext{
${ }^{75}$ Em suas negociações inter-regionais com o GCC, a UE tem reforçado a conexão entre relações comerciais e segurança, tendo em vista que incorporou as relações à sua Estratégia de Europa Ampliada (Wider Europe Strategy) (ANTKIEWICZ \& MOMANI, 2009, p. 18)
} 


\subsubsection{Preferências das instituições da UE}

Mandato de negociação

O mandato de negociação original data de 1991, e foi atualizado por uma decisão do Conselho de 16 de julho de 2001, a fim de levar em consideração desenvolvimentos na OMC ao incluir serviços, direitos de propriedade intelectual, compras governamentais e outras áreas incluídas em acordos de comércio mais recentes.

O GCC preencheu uma precondição da UE de entrada em vigor de um APC, com a mudança do estabelecimento de uma União Aduaneira de 2005, para $1^{\circ}$ de Janeiro de 2003 durante a cúpula de chefes de Estado em Muscat, Omã, no ano novo (2002).O APC proposto garantiria uma liberalização progressiva e recíproca do comércio a fim de garantir um nível comparável de oportunidades de acesso a mercado, consistente com as provisões relevantes da OMC e levando em consideração o nível de desenvolvimento dos países do GCC. O APC, portanto, visa em última instância a forjar integração econômica entre as partes, com vistas a diversificar e aumentar o comércio mútuo de uma maneira sustentável. (COMISSÃO EUROPÉIA, 2002)

De acordo com Youngs (2009, p. 2), os formuladores de política da UE justificam a abordagem regional com o GCC com três argumentos principais: a) que a UE não tem capacidade suficiente para negociar bilateralmente com todos estados do GCC; b) é parte da identidade internacional distintiva e inerente da UE que modelos de integração regional similares ao seu próprio deveriam ser promovidos; c) haveria pouco ganho em avançar com os estados menores do GCC, quando apenas a Arábia Saudita realmente conta como um aliado econômico e geopolítico ${ }^{76}$.

\footnotetext{
${ }^{76}$ Também de acordo com Youngs (2009, p.3), nenhum desses argumentos é completamente convincente. $\mathrm{O}$ fato de que a Comissão tem apenas uma delegação para o GCC, uma missão pequena
} 
Os formuladores em política da UE e do GCC não especificam um horizonte de tempo para alcançar o APC, conforme Kostadinova (2013) destacou por meio de entrevistas:

"Várias questões principais tem contribuído para esse histórico fraco: a oposição de produtores petroquímicos europeus; a adoção de taxação mais elevada de carbono pela UE; os atrasos do GCC em estabelecer uma união aduaneira; desentendimentos acerca das provisões do acordo; notadamente a inclusão das assim chamadas "cláusulas de direitos humanos", impostos de exportação (SREEKUMAR, 2009), e a habilidade de companhias estrangeiras de deter parcelas grandes das companhias do GCC. (CAREY \& MAHDI, 2010). Todos esses são fatores que tem obstruído o desenvolvimento das relações UE-GCC" (KOSTADINOVA, 2013, p. 3)

Os Estados-Membros da UE tem frequentemente desenvolvido uma política externa independente, portanto preservando tanto quanto possível em termos de liberdade de manobra no que se refere a relações com os países do GCC. Esse é o caso, por exemplo, do Reino Unido, França, e Alemanha, cada um dos quais tem tentado cultivar uma relação privilegiada com países individuais do GCC. O descompasso entre as políticas externas bilaterais dos Estados Membros da UE em relação ao Golfo, e o quadro de cooperação multilateral EU-GCC, tem frequentemente deixado as instituições da UE na posição desconfortável de advogar pela aplicação da condicionalidade nas relações UE-GCC. Por outro lado, os Estados Membros da UE têm continuado a perseguir seus interesses - mesmo indo contra as políticas da UE. (COLOMBO, 2017, p. 66)

No documento Trade for All de 2015, na seção 5.2.2, a Comissão reafirma seu interesse em assinar um acordo de livre comércio com o GCC. Esta é a única menção à região do golfo

aberta em Riyadh em 2004, crescentemente parece uma escolha equivocada de política. Da mesma forma que a propensão a permitir que as relações sejam feitas reféns das diferenças com a Arábia Saudita, visto que outros estados na região tornam-se atores mais significativos. A adoção pela UE de uma abordagem regional negligencia as diferenças sociais, políticas e econômicas entre os seis países e ignora como elas condicionam o escopo da UE para ação. Assim, Youngs enfatiza que alguma forma de "regionalismo gradual" seria oportuno, permitindo um grau de bilateralismo, tal como, por exemplo, sob a ENP (Política Européia de Vizinhança) 
em todo o documento, e aparece junto a uma referência ao acordo nuclear com o Irã, apontada como um passo importante para a posterior intensificação das relações comerciais com o país, inicialmente por meio da integração iraniana à OMC.

Em um workshop no âmbito do parlamento europeu, Cornock (2017) enfatiza que a UE tem grande experiência em desenvolver cadeias de valor para além de fronteiras, a economia verde, tecnologia para finanças e indústria relacionada a ciência e tecnologia (ICT). Em síntese, está claro que enquanto o acordo de livre comércio UE-GCC estiver por ser assinado, o potencial completo dessa importante relação inter-regional não poderá ser completamente realizado. Atrasos adicionais a isso colocam em risco oportunidades importantes para ambas as partes. 


\section{Cabos diplomáticos - Wikileaks (2003-2010)}

Uma busca pelas palavras-chave GCC, UE e comércio ("trade”) resultou em cinco comunicações diplomáticas de interesse para os propósitos desta tese. Esses cabos diplomáticos foram enviados ou por representações dos EUA em países do GCC, ou em representações norteamericanas na Europa, especialmente junto à embaixada dos EUA junto à UE. Nesta seção procede-se à análise do conteúdo desses documentos, a fim de se identificar decisões e avaliações importantes de altos funcionários da União Europeia, ou de membros de seu corpo diplomático, no que se refere à manutenção de um desenho de negociação inter-regional para a região do Golfo; a competição com atores rivais, ou a coesão dessa organização regional.

Em um telegrama de 11/04/2005, o chefe da missão diplomática dos EUA no Kuwait enfatizou que:

"Durante consultas em uma variedade de assuntos com meus pares da UE hoje, eles notaram que durante o encontro ministerial recente UE/GCC no Bahrein, o Comissário da UE para o Comércio criticou os membros do GCC por perseguir acordos bilaterais de comércio com os EUA. [...] O desgosto de Mandelson continuou até o communiqué emitido no fim da reunião de 5 de abril no Bahrein. O texto lê: "A União Europeia emitiu sua visão no que se refere a acordos bilaterais de comércio por países individuais com outros países terceiros. A UE considera processos de integração econômica regionais como instrumentos importantes para a paz, estabilidade e prosperidade". De acordo com um participante, a palavra "visão" teria substituído "preocupação", de um rascunho anterior".

Igualmente, em um cabo diplomático de 31/10/2006, o embaixador dos EUA no Japão sublinha a preocupação japonesa com a competição com a China e a UE na região do Golfo:

"De acordo com Tamura [Vice-Diretor do Departamento de Economia], a data-alvo para completar o APC ainda está indefinida, mas os Japoneses estão ansiosos para completar o acordo rapidamente. Eles estão conscientes de que o GCC está negociando um APC com a União Europeia por mais de dez anos, e de que recentemente entraram em negociações com a China. Os líderes empresariais japoneses estão urgindo o governo a mover-se rapidamente, preocupados de que se outros países ou blocos comerciais 
concluírem APCs com o GCC primeiro, os bens e serviços do Japão estarão em desvantagem no mercado do GCC."

Em um cabo secreto enviado da representação dos EUA junto à UE (Bruxelas), de 23/09/2008, no contexto do impasse referente ao programa nuclear iraniano, também ficou evidente a importância do GCC em termos de segurança para a UE:

\begin{abstract}
"Cooper também perguntou se os EUA estavam fazendo progresso no Golfo, a rota óbvia para circumventar sanções? Cooper disse que os 33 podem sublinhar isso em um encontro próximo com o GCC. Levey garantiu a ele de que os mais altos níveis estão engajados em lidar com isso; pelo menos a rota foi reduzida a um conduite via Dubai. Tendo em vista os temores deles tanto de um Irã nuclear e de fazer frente ao regime, os estados do Golfo estão pressionando silenciosamente sem anúncios à imprensa"
\end{abstract}

Alguns elementos da análise documental e da literatura secundária ficaram confirmados por um cabo enviado pelo Vice-Embaixador dos EUA em Riyadh em 18/07/2009. Em especial, a baixa coesão dos membros do GCC, que não se consultam entre as negociações; ademais, enfatiza-se a percepção dos vice-chefes de missão da Austrália e Nova Zelândia, de que o GCC estaria usando as negociações com seus respectivos países como um proxy para negociações com parceiros comerciais grandes; por fim, ressalta-se o papel predominante da Arábia Saudita na condução das negociações, em detrimento dos países menores do Golfo.

“Ambos vice-chefes de missão expressaram frustração com o GCC, chegando mesmo a questionar a motivação do GCC para negociar os acordos. Noble implicou que os Sauditas podem estar usando as negociações como um exercício de treinamento para acordos futuros com parceiros comerciais maiores, notando que os chineses o tinham feito abertamente com o país dele em negociações bilaterais. Ambos enfatizaram repetidamente que a falta de consultas interinas entre os estados membros, dificultava seriamente o progresso que poderia ser fácil de alcançar de outra forma. 'Eles não conversam entre eles, entre as rodadas de encontros', um disse, 'eles apenas retornam a suas capitais até a próxima rodada'. Os dois vices chefes de missão afirmaram que a Arábia Saudita controla o GCC nas negociações e tem usado os membros menores do GCC como peões no processo convencendo outros membros individuais a fingir ser o opositor solitário a uma proposta, quando de fato todos os seis membros na verdade já estavam em oposição" 
Igualmente, o telegrama traz uma avaliação da posição japonesa no desenvolvimento das negociações, por meio de comunicação feita pelo vice chefe de missão do Japão ao oficial de economia dos EUA:

"O VCM japonês Fumio Iwai disse ao Econoff em um encontro separado que o GCC adiou a rodada de julho de suas negociações de livre comércio com o Japão. 'Nós estamos no mesmo barco que os australianos', ele disse, em que o ponto de impasse nas negociações deles é a tarifa automotiva de cinco por cento. Iwai disse que os sauditas tinham a maior oposição a reduzir a tarifa, e ele notou que a questão tinha sido levantada nos mais altos níveis bilaterais. "'

Um elemento que também corrobora a literatura secundária, é a inflexibilidade do GCC nas tratativas, evidenciado, conforme enfatizamos mais acima, pela retirada unilateral do bloco das negociações em 2008. Assim avalia o VCM dos EUA em Riyadh:

"Tendo em vista que os oficiais do GCC nos tinham dito anteriormente que eles também estão em negociações para um APC com a China, Japão, e Turquia, parece provável que os temores do VCM da Nova Zelândia de que o GCC esteja usando suas negociações separadas com a Austrália e Nova Zelândia podem ser bem-fundadas. No entanto, isso não significa que o GCC queira que elas fracassem. $\mathrm{O}$ fracassso das negociações no fim de 2008 demonstraram uma inflexibilidade que também parece em curso aqui. Um ponto brilhante: ambos os VCMs notaram que a conclusão bem-sucedida dos APCs dos EUA com o Bahrein e Omã tinha influenciado positivamente a atmosfera de negociação."

Apesar das dificuldades enfatizadas para a conclusão das negociações entre a UE e o GCC, conforme enfatizamos ao longo da análise documental, em um cabo diplomático de 15/02/2010 a embaixada em Riyadh notou a comunicação do secretário do GCC de que o bloco estaria muito próximo de concluir um acordo com a UE. Igualmente, os diplomatas do golfo sublinharam que a conclusão de um acordo com o conjunto dos países do GCC seria mais vantajoso para os EUA: 
"Al-Mazrooei fez uma forte afirmação de que lidar com o GCC como um todo ofereceria aos EUA um mercado de comércio e investimento muito maior do que estados individuais, representando em torno de 40 milhões de pessoas. O GCC tem considerado atrativo, para um número de outros parceiros, com quem tem negociado acordos de livre-comércio. Al-Mazrooei notou que o GCC está muito próximo de finalizar seu acordo com a UE (oficiais do GCC nos disseram que restam apenas dois artigos). O GCC entende que a preferência dos EUA é por acordos bilaterais, mas Al-Mazrooei fez um movimento forte para considerar concluir um com o GCC como um todo, o que ele argumentou que poderia ser muito mais rápido do que tentar obter a mesma vantagem ao negociar país por país"

\subsubsection{Resultados}

A análise do material empírico para a Hipótese 1 não encontrou evidência de novas iniciativas visando à assinatura de um acordo bilateral entre a UE e algum dos membros do GCC; embora haja o monitoramento europeu das atividades de atores rivais na região do Golfo. Portanto, na primeira dessas instâncias a hipótese não passa um hoop test, e na segunda sim. Os dados empíricos também permitem afirmar que a UE também não avalia adotar uma política específica em relação a potências emergentes a fim de salvaguardar seus interesses de segurança econômica, e assim a Hipótese 1 não passa um teste straw-in-the-wind na segunda etapa do mecanismo causal.

A UE buscou assinar novos acordos de comércio concomitantemente com a tentativa de concluir as negociações para o APC com o GCC, quando os países do Golfo se retiraram unilateralmente da mesa de negociação em 2008. Assim, os dados empíricos permitem afirmar que a Hipótese 2 passa um teste straw-in-the-wind inicial. Adicionalmente, houve a manutenção do objetivo europeu de manter o desenho do acordo no formato inter-regional, conforme enfatizado ao longo da análise documental e do mandado de negociação atualizado em 2001, fornecendo evidência que dá suporte ao segundo elemento do mecanismo causal - e 
assim a hipótese passa um teste hoop. Nenhum dos documentos consultados, literatura secundária, ou manifestações oficiais da UE permitem afirmar que a quantidade crescente de negociações pressionou a capacidade administrativa europeia, especialmente após a publicação da estratégia Global Europe em 2006. Portanto a Hipótese 2 não passa um teste hoop nesse caso.

Conforme evidenciado pela análise de dados empíricos, a UE enfatiza a necessidade de combinar abordagem inter-regional nas negociações com o GCC junto com estratégias nas arenas bilateral e multilateral. O documento-chave da atuação externa do bloco (ESS) é posterior ao mandato de negociação atualizado de 2001, assim pode-se esperar que tenha impactado apenas a tentativa de relançamento das negociações em torno de 2008. E a versão atualizada dessa estratégia, conforme enfatizamos mais acima, foi produzida apenas em 2016. Portanto, é possível afirmar que a Hipótese 3 passa um teste smoking-gun nesse caso.

A análise de material empírico mostra a crescente irrelevância da UE na região do Golfo, especialmente no contexto pós-crise de 2008 , em que se intensificou a competição com os países BRICS. Essa peça de evidência dá suporte à Hipótese 3, que passa um teste hoop nessa parte do mecanismo causal. No entanto, nenhum dos documentos consultados evidenciou que o GCC tenha servido ao propósito da UE de buscar novos acordos com grandes potências no período pós-crise de 2008 - o que nos permite afirmar que a hipótese não passa um teste smoking-gun nesse caso.

Os dados empíricos permitem afirmar que a UE, por meio do SEAE, da Comissão e de sua delegação junto ao GCC, monitora essa organização regional a fim de garantir seus objetivos de política externa econômica. Portanto, a Hipótese 4 passa um smoking-gun fraco nessa parte do mecanismo causal. Igualmente, conforme exposto mais acima, os formuladores de política da UE têm insistido no formato inter-regional de negociações de comércio com o 
GCC - apoiando, portanto, a hipótese, que passa um teste hoop nessa parte do mecanismo causal. A análise empírica revelou também a exigência europeia para a conclusão da União Aduaneira pelo GCC, a fim de que se viabilizasse o acordo inter-regional, mesmo em um contexto de progresso lento na cooperação nessa esfera. Portanto essa peça de evidência apoia a Hipótese 4, que passa um teste smoking-gun. 


\subsection{Estudo de caso III: TTIP (Parceria transatlântica de investimento e comércio)}

Antes de terem sido suspensas pela administração Trump, a UE e os EUA concluíram 15 rodadas de negociações do TTIP. As negociações que começaram entre a UE e os EUA em julho de 2013 intensificaram-se desde meados de 2015 e mostraram progresso significativo em certas áreas. No entanto, não se trata do primeiro tratado que a UE negocia depois da entrada em vigor do tratado de Lisboa (DELIMATSIS, 2017, p. 587). A literatura atual sobre regionalismo apenas começou a investigar os mega-APCs, talvez porque eles ainda estão em negociação ou não chegaram a lugar algum no passado - mas esses acordos podem evidenciar um movimento em direção a uma nova forma de coordenação regulatória (BORZEL \& KIM, 2017).

De acordo com Bossuyt et. al. (2018), desenvolvimentos recentes nas relações exteriores da UE, em particular as negociações de comércio UE-EUA e o conflito com a Rússia na Europa Oriental tem levado observadores a apontar para o "retorno da geopolítica" na Europa (GUZZINI, 2013; SMITH, 2016; YOUNGS, 2017). Nesse contexto, o comércio estaria fadado a estar subordinado à política externa. Alguns argumentam, por exemplo, que a principal razão por que a UE e os EUA abraçaram o objetivo ambicioso de completar a Parceria Transpacífica de Investimento e Comércio seria geopolítica por natureza (VAN HAM, 2013) ${ }^{77}$. E conforme enfatizamos nos capítulos iniciais da tese, o novo documento "Trade for All" sugere uma abordagem mais impulsionada por valores à política comercial (Comissão Europeia, 2015). Por outro lado, a Estratégia Global da UE chama por maiores sinergias entre comércio e desenvolvimento para consolidar os esforços de construção da paz da UE em zonas de guerra. (BOSSUYT ET AL., 2018, p.4)

\footnotetext{
${ }^{77}$ Em uma contribuição mais recente de um funcionário da Comissão Européia, também sobressaem-se os motivos adicionais de por que a UE estaria negociando o TTIP: a) contra-peso político e comercial ao TPP; b) posicionamento em relação à China (e os BRICs); c) interesses econômicos; d) estabelecer um modelo para acordos comerciais (tendo em vista o impasse nas negociações da OMC)
} 
Reforçando uma análise avançada no segundo capítulo da tese, de 2006 a 2009 a UE pode ter buscado parceiros bilaterais dentre novos atores comerciais importantes (Índia, ASEAN e Coréia do Sul), para complementar ou mesmo facilitar um acordo multilateral (GARCIA-DURAN \& MILLET, 2015). Desde esse momento, porém, a UE pode ter se focado em alcançar acordos com parceiros mais importantes ainda: os velhos membros do Quad (Canada, Japão, e os EUA) como uma forma de garantir as oportunidades de acesso a mercado que não podia mais esperar obter da Rodada Doha. Seguindo essa análise, conforme enfatizam (GARCIA-DURAN \& MILLET, 2015, p. 2), o TTIP deveria ser lido, pelo menos no curto prazo, como um exemplo de bilateralismo eficiente.

Talvez paradoxalmente, apontam Delimatsis et al. (2017), um engajamento potencial renovado com o TTIP no lado dos EUA poderia reviver o interesse dos países pela OMC, pois isso os lembraria dos ganhos de comércio mais livre e permitiria alguma criatividade em lidar com assuntos urgentes relacionados ao comércio que envolvem as duas potências comerciais. Com um volume combinado de comércio transatlântico de cerca de $€ 400$ bilhões, representando mais da metade do comércio global em serviços, os serviços são um componente chave de um futuro acordo transatlântico. O TTIP constitui um ponto de virada para a regulação e liberalização global de serviços e vai ter efeitos sinalizadores para o resto do mundo no que se refere a possíveis direções a serem tomadas nessa área. 


\section{$\underline{\text { Histórico e posicionamento dos Estados Membros }}$}

Tentativas de negociar um APC com os EUA foram feitas repetidamente no passado. Por exemplo, em 1998, o então Comissário para o Comércio Leon Brittan propôs abrir negociações de livre comércio, mas esse movimento foi prontamente colocado em espera após forte oposição do Conselho. Além da França, que resistiu a proposta de Brittan mais intensamente, um número amplo de países, incluindo a Holanda, Alemanha, Bélgica, Espanha e Itália, todos manifestaram reservas sobre a iniciativa da Comissão. A Dinamarca, Finlândia, Luxemburgo, Suécia, Portugal e (embora menos claramente) Grécia apoiaram os planos. Em 2006, Angela Merkel lançou outra tentativa de colocar as negociações transatlânticas na agenda, mas esses planos foram silenciosamente postergados após os EUA deixarem claro que sua agenda sobrecarregada de comércio e relações exteriores não permitia tais tratativas (AGENCE EUROPE 1998, 2007; DER SPIEGEL 2007, INSIDE US TRADE 1998). (BOLLEN ET. AL, 2016, p. 283)

Também a partir do estudo e entrevistas conduzidos por Bollen et al. (2016), é possível afirmar que, no caso do atual texto, não houve oposição à proposta de lançar negociações com os EUA. Assim, a França, que poderia ter usado seu poder de veto para barrar a autorização à Comissão, apenas pediu que o capítulo referente a serviços audiovisuais fosse retirado do mandado de negociação - o que tem se tornado prática corrente na diplomacia comercial da UE. O mandato de negociação para a Comissão foi unanimemente aprovado pelos Estados membros e o Conselho tem enfatizado a necessidade de concluir rapidamente as negociações de um acordo ambicioso, sem dissidência significativa.

No entanto, campanhas públicas e de larga-escala forçaram os reguladores de comércio da UE a reajustarem suas posições e desenvolver consultas mais inclusivas durante as 
negociações para o $\mathrm{TTIP}^{78}$. As eleições presidenciais de 2016 nos EUA mostraram que os sentimentos anti-comércio não são uma especialidade europeia e, sob a presidência de Donald Trump, tem moldado consistentemente a política americana. O candidato Trump prometeu terminar as negociações para o TPP e assim o fez em 23 de janeiro de 2017. A visão sombria de Trump a respeito da globalização coloca em dúvida a possibilidade de conclusão do TTIP (LAURSEN \& ROEDERER-RYNNING, 2017, p. 765), porém, mais recentemente o Secretário de Comércio dos EUA, Wilbur Ross, enfatizou que havia a possibilidade de um acordo com a $\mathrm{UE}^{79}$.

\footnotetext{
${ }^{78}$ Os opositores focam-se no impacto potencial do TTIP nos padrões de política publica e segurança, refletindo suas preocupações com ameaças percebidas ao status quo da UE, e vontade de preservar o mesmo. Ao escolher deliberadamente questões específicas para evocar os medos maiores, eles reuniram oposição pública inesperada e sem precedente a um acordo comercial (ELIASSON, 2017). Para mais detalhes, ver o artigo "38 arguments against TTIP", de Klimenta et al. (2016), disponível em https://www.indybay.org/newsitems/2016/05/09/18786237.php.

${ }^{79}$ Entrevista à Bloomberg de 28/03/2018. Site: https://www.bloomberg.com/news/articles/2018-0329/trump-willing-to-reopen-ttip-amid-eu-u-s-trade-spat-ross-says
} 


\section{Mandato de negociação}

O Conselho adotou unanimemente as diretivas de negociação (o "mandato") endereçado à Comissão em junho de 2013.Nas suas diretivas, o Conselho estabelece as linhas gerais de ação que veiculam os objetivos gerais que a Comissão deveria buscar alcançar durante as negociações. O Conselho primeiro posiciona as negociações dentro do quadro do que o novo Artigo 21 do Tratado Sobre a UE (TUE) estabelece para a ação externa da UE. Interessantemente, o mandato enfatiza que a UE e os EUA compartilham valores e princípios fixados no Artigo 21, incluindo a proteção dos direitos humanos, democracia, e estado de direito, desenvolvimento sustentável, e o direito a regular para proteger objetivos nãoeconômicos, incluindo a promoção da diversidade cultural (DELIMATSIS, 2017).

O mandato chama por um acordo comercial que será essencialmente tradicional, visto que vai cobrir taxas e acesso a mercado, e ao mesmo tempo é inovador ao abranger questões regulatórias, cooperação regulatória em questões tal como barreiras técnicas ao comércio e regulamentos de segurança alimentícia, bem como proteção ao investimento. (COMISSÃO EUROPÉIA, 2018) 


\section{$\underline{\text { Resultados }}$}

Em síntese, as motivações da UE para entrar em negociação com os EUA centram-se essencialmente nos objetivos de manter o status quo do bloco no sistema de comércio internacional, bem como atingir objetivos de natureza econômica, conforme firmados na estratégia Global Europe de 2006. Enfatiza-se a relevância do objetivo europeu de fazer frente à competição com os BRICS (essencialmente a China), além de avançar a cooperação regulatória, e viabilizar uma alternativa ao sistema da OMC.

Conforme exposto na introdução a este estudo de caso, a literatura de regionalismo que trata dos mega-acordos de comércio ainda é muito incipiente. Nesse sentido, são bem-vindas contribuições que enfatizam o aspecto geopolítico desse tipo de negociações, a exemplo da abordagem do Realismo Comercial. Igualmente, o caso do TTIP não encontra precedentes nas iniciativas bilaterais da UE, e, portanto, merece uma análise mais aprofundada por parte da comunidade acadêmica de relações internacionais.

Embora o contexto atual definitivamente apresente dificuldades para a conclusão de um acordo de livre comércio entre os EUA e a UE, vale enfatizar alguns motivos para a continuidade das negociações, do ponto de vista da UE, a partir da contribuição de Bianchi (2016), membro do departamento jurídico da Comissão Europeia: melhorias na transparência nas negociações; mecanismos institucionais novos e mais democráticos e transparentes (Corte permanente para investimentos); resposta a um sentimento universal anti-comércio; resposta a um certo individualismo egoísta de alguns países. 


\subsection{Estudo de caso IV: Mercosul (2016-atual)}

Conforme enfatizamos ao longo da análise dos outros estudos de caso, a UE tem priorizado, recentemente, a conclusão de acordos com parceiros estratégicos importantes ${ }^{80}$. Assim, não apenas as negociações com EUA, Japão e Canadá tem estado no centro das atenções dos formuladores de política da UE, mas também o Brasil, China, Índia e Rússia (DELIMATSIS, 2017; MEISSNER, 2016; VAN LOON, 2015). As negociações para a assinatura de um acordo de livre-comércio entre a UE e o Mercosul tiveram início em 1999. Uma mudança significativa da parte do bloco europeu foi a decisão de lançar uma parceria estratégica com o Brasil no ano de 2007, representando uma mudança de ênfase para a arena bilateral.

A questão de se o desenvolvimento de vínculos bilaterais da UE com países terceiros pode contribuir para o desenvolvimento e implementação de uma estratégia geral para a política externa da UE - tem sido objeto de algum debate (KHANDEKAR, 2013; WHITMAN \& RODT, 2012) (SCHADE, 2017, p. 2). Este estudo de caso analisa brevemente a evolução das negociações no período 1999 - 2015, examinando em maior profundidade o período de 2016 até o momento atual. A literatura de política comercial da UE, incluindo em sua vertente realista, já analisou de forma abrangente os períodos mencionados, porém contribuições mais recentes estão começando a abordar a crise política no Brasil, o "Brexit" (ou a decisão do Reino

\footnotetext{
${ }^{80}$ No que se refere à mudança da UE em 2006 (Global Europe), a emergência das economias asiáticas e preocupações em relação a competidores-chave no comércio, em particular os EUA intensificando esforços para buscar acordos comerciais bilaterais, não deve ser menosprezada (GARCIA, 2012). No contexto da competição "UE-EUA no comércio", isso é visto como motivado pela necessidade de não ser deixado de lado. (VAN LOON, 2018, p. 7)
} 
Unido de sair da UE), bem como a eleição de Donald Trump nos EUA - e seus efeitos para um acordo inter-regional UE - Mercosul.

Na Estratégia Global da União Europeia, vínculos mais fortes com os países da América Latina e Caribe são vistos como parte da estratégia da UE para fortalecer a parceria transatlântica (TTIP) (EUGS, 2016). O documento afirma que a UE vai almejar um acordo de livre comércio com o Mercosul e de fato desde 2016 os esforços de negociação intensificaramse (dez rodadas de negociação desde outubro de 2016) (PEÑA, 2018). Assim, este estudo de caso soma-se às contribuições de Meissner (2016); Sahakyan (2015); Schade (2016) e Van Loon (2018), que se centram nas motivações da UE para negociar um acordo, e o desenvolvimento das negociações no período até o ano de 2016.

\section{9-2004}

As divisões dentro da Comissão Europeia moldaram a linha do tempo para garantir um mandato de negociação e o conteúdo do mandato em si. Isso deveu-se principalmente ao fato de que o Comissário Marin, e o Comissário para Agricultura, Franz Fischler, tinham interesses divergentes na matéria, antes de pedir ao Conselho para garantir um mandato de negociação em julho de 1998 (SCHADE, 2016, p. 142). E, em um momento posterior, Brittan, o Comissário responsável pelas negociações da UE com países desenvolvidos, também se opôs a negociações com o Mercosul - apenas mudando de posicionamento quando do fracasso de sua iniciativa de lançar conversas com os EUA para o que seria o embrião do atual TTIP. (SCHADE, 2016, p. 143). Conforme enfatizamos no estudo de caso a respeito desse acordo - a França foi o principal Estado-Membro opositor ao acordo com os EUA. 
Os pesquisadores têm interpretado as negociações UE-Mercosul para um AA (19992004) como um exemplo do poder normativo da UE, com que ela apoia a integração regional e vende seu próprio modelo (BORZEL \& RISSE, 2009; HANGGI, 2003; SANTANDER, 2002) (MEISSNER, 2016, p. 151). No entanto, o estudo de Meissner (2016) deu evidência empírica a respeito dos interesses materiais da UE em lançar o formato inter-regional, que teria sido muito mais uma contra iniciativa aos EUA (SBRAGIA, 2010), do que uma política motivada normativamente.

Van Loon (2015, p. 243) também argumenta nessa linha:

"A ascensão de grupos econômicos como o Mercosul, e esforços crescentes dos EUA a fim de fortalecer esquemas de integração econômica tais como o NAFTA ou a ALCA, são fatores significativos ao moldar a política da UE a fim de melhorar sua posição no sistema internacional. Também, a ascensão do Brasil como uma potência emergente, seu poder crescente e ambição de mudar a distribuição do sistema internacional é um fator decisivo que molda a política da UE em relação ao Brasill".

Portanto, o perfil econômico e político do Brasil foi um elemento importante na avaliação da UE anterior ao lançamento da parceria estratégica com o país. Igualmente, a primeira metade da década de 2000 foi favorável à estabilização e crescimento econômicos do país - e, em adição, a partir do início do primeiro mandato do Presidente Lula (2003-2006), a integração regional no âmbito do Mercosul foi uma prioridade de política externa, um período que também foi marcado por um alto grau de coesão dessa organização regional, conforme a análise empírica de Meissner (2016) demonstrou. 


\section{7 (Parceria Estratégica)}

De acordo com Meissner (2017), o Mercosul é a organização regional no mundo em desenvolvimento com que o inter-regionalismo tinha a maior probabilidade de ocorrer. Isso se deve a três razões: primeiro, o Mercosul era percebido, no anos 1990, como a organização regional mais bem-sucedida entre os países em desenvolvimento (VAILLANT, 2005); segundo, os estados membros chegaram a um acordo bem cedo sobre uma união aduaneira forçando-os a negociar APCs como um grupo (DUINA \& BUXBAUM, 2008); terceiro, a UE e o Mercosul assinaram um Acordo Quadro de Cooperação Inter-regional (1995), com que eles se comprometeram com o inter-regionalismo como um princípio guiador. Mesmo assim, aponta Meissner, a UE mudou para uma estratégia bilateral quando lançou a Parceria Estratégica com o Brasil em 2007.

A partir de entrevistas realizadas por Hoffmann (2009) junto a oficiais da UE na Comissão e no Parlamento Europeu, à época da decisão de lançar a Parceria Estratégica com o Brasil, é possível afirmar que não havia um consenso a respeito da necessidade de mudar de uma abordagem inter-regional. Pelo contrário, "houve resistência à proposta - que parece ter sido contestada por muitos" - e assim a ênfase na arena bilateral deve ser analisada no quadro mais amplo da política externa europeia (HOFFMANN, 2009, p. 56).

\section{0-2015}

A partir do momento em que a UE e o Mercosul pararam as negociações, não houve progresso ou uma intenção real de reiniciar as negociações até $2010^{81}$. Oficialmente, a UE e o

\footnotetext{
${ }^{81}$ Em 2010 houve uma atualização do mandato original de 1999.
} 
Mercosul continuaram a negociar o acordo de associação, mas após a falha no último minuto em 2004, ambos os lados tinham se tornado cautelosos em suas esperanças de um acordo bemsucedido. (ARANA, 2017, p. 179). Desde 2010, diversas rodadas de negociação ocorreram, mas ressalta-se o fato de que, no ano de 2015, um novo modo de negociação em duas velocidades parece ter sido aberto: de um lado, negociações com o Brasil e outros países, tais como Uruguai e Paraguai; e de outro, com a Argentina. (ARANA, 2017, p. 179). 


\section{6-período atual}

Em maio de 2016 o vice-presidente Michel Temer assumiu o poder interinamente. Concomitantemente à turbulência política no Brasil, o Reino Unido preparava-se para o referendo sobre a permanência na UE, em 23 de junho do mesmo ano. As pesquisas de opinião mostravam uma diferença pequena de votos, com projeção de vitória do campo pró-Europeu ("remain"). Como se sabe, o resultado favoreceu o campo dos soberanistas da campanha do leave, liderada por Farage.

Michel Temer assumiu o poder em definitivo em $1^{\circ}$ de setembro de 2016 , prometendo reorientar a política externa brasileira, em direção a relações mais próximas com a Europa e os EUA. E, igualmente, a política econômica adotada - sob o comando de Henrique Meirelles prometia maior liberalização e abertura internacional. Semelhantemente ao referendo do Brexit, as pesquisas de intenção de voto mostravam uma disputa acirrada entre Clinton e Trump nas eleições que se aproximavam no EUA, também marcadas por escândalos envolvendo os dois candidatos. Com a vitória do republicano em 08 de novembro de 2016, o cenário mundial havia se modificado profundamente, de forma ainda mais intensa que o impacto derivado do Brexit, ou do processo do impeachment no Brasil.

Assim, as negociações para um APC entre UE e Mercosul, retomadas em outubro daquele ano, também entraram em um momento drasticamente diferente dos períodos anteriores. O otimismo inicial de Temer para a conclusão do acordo, até o final de 2016, rapidamente se provou infundado - e a perspectiva de uma escalada no protecionismo global, a partir da política econômica de Donald Trump, também não sinalizavam boas perspectivas para a abertura externa da economia brasileira. No que se refere ao Brexit, a decisão britânica 
apenas aprofundou a crise que a UE já se encontrava em função da instabilidade da zona do Euro e da imigração ${ }^{82}$.

No entanto, as perspectivas para um acordo UE - Mercosul tornar-se-iam ainda mais complicadas com o aprofundamento da crise política brasileira em maio de $2017^{83}$. Denúncias de corrupção atingiram, nesse mês, o presidente Temer e figuras importantes da Social Democracia do país - inclusive com provas materiais de compra de parlamentares - e levaram à abertura de duas denúncias contra o presidente ${ }^{84}$. Igualmente, em julho do mesmo ano o expresidente Luiz Inácio Lula da Silva foi condenado por lavagem de dinheiro e corrupção passiva, o que na prática acirrou de forma mais aguda a polarização política no país. O contexto regional também trouxe instabilidade maior ao Mercosul com a suspensão temporária da Venezuela do bloco em dezembro de 2016, e reiterada em agosto de 2017 - em função das eleições ocorridas no país ${ }^{85}$.

De outubro de 2016 até o fim de 2017 ocorreram cinco rodadas de negociação entre a UE e o Mercosul. A 30ª rodada de negociação da Parte Comercial do Acordo de Associação aconteceu de 6 a 10 de novembro de 2017 em Brasília. Os grupos de trabalho de negociação cobriram, dentre outras, as seguintes áreas: comércio de bens; soluções de controvérsia; serviços; compras governamentais; propriedade intelectual; comércio e desenvolvimento sustentável. Adicionalmente, ambos os lados adotaram passos para se preparar para uma troca de ofertas de mercado melhoradas. (COMISSÃO EUROPÉIA, 2017). A rodada de negociação

\footnotetext{
${ }^{82}$ Para uma análise detalhada sobre a crise, ver Caporaso (2018).

${ }^{83} \mathrm{Em} 2016$, os dois blocos fizeram a primeira troca de oferta de mercados desde 2006, evidenciando o ritmo lento do progresso das negociações. Em Outubro de 2017 a França propôs à Comissão Européia uma atualização do mandato de negociação, para incluir medidas de segurança alimentar - após os escândalos da venda de carne de cavalo na Europa e de carne adulterada no Brasil (REUTERS, 2017).

${ }^{84}$ Michel Temer tinha, à época, aprovação de menos de 5\% da população. Em março de 2019 o exPresidente foi preso, acusado de chefiar uma organização criminosa por mais de 40 anos.

${ }^{85}$ À época, o chefe do departamento de América do Sul do SEAE enfatizou a dificuldade representada pela Venezuela para a conclusão do acordo. Ver artigo do jornal O Globo, disponível em https://oglobo.globo.com/economia/ue-ve-venezuela-como-possivel-obstaculo-para-acordo-commercosul-19661835.
} 
mais recente (trigésima sexta) aconteceu de 12 a 20 de novembro de 2018 em Bruxelas, na Bélgica, em nível de especialistas e negociadores chefe. (COMISSÃO EUROPÉIA, 2018). A tendência a um progresso lento nas negociações ${ }^{86}$ foi reconfirmada na cúpula mais recente do Mercosul em dezembro de 2018, quando o bloco sul-americano encerrou o evento com um memorando de cooperação com a UEE (União Econômica Eurasiática) ${ }^{87}$.

${ }^{86}$ Em Junho de 2019, 340 organizações da sociedade civil enviaram uma carta ao dirigentes das instituições da UE, pedindo a suspensão das negociações entre o bloco europeu e o Mercosul. O principal motivo apontado foram as degradações ao meio ambiente e a falta de respeito a normas de direitos humanos no Brasil.

${ }^{87}$ A UEE é composta pelos seguintes países: Armênia; Bielorrúsia; Cazaquistão; Quirguistão; e Federação Russa. 


\section{Resultados}

As negociações da UE com o Mercosul não produziram resultados conclusivos, entre outros motivos, por causa da resistência da região ao tipo de liberalização além de fronteiras, inclusive em direitos de propriedade intelectual, medidas de investimento e comércio em serviços, demandados pela UE. Até o ano de 2015, a partir do trabalho empírico e de entrevistas realizado por Sahakyan $(2015$, p. 37), esses parecem ter sido os motivos principais para a nãoconclusão das negociações.

O aspecto da coesão do Mercosul também parece ser um fator explicativo importante para a mudança de ênfase da UE, do formato inter-regional de negociações, para a parceria estratégica. A partir do indicador de coesão desenvolvido por Meissner (2016), e explicado no capítulo 3, é possível afirmar que a decisão de assinar a P.E. com o Brasil foi uma resposta à competição com a China e EUA na região - em um contexto de impasse na arena inter-regional em função da fragmentação do Mercosul (MEISSNER, 2017). A análise do período posterior a 2016 aponta para um quadro de fragmentação ainda maior no bloco regional, em função do agravamento das crises domésticas na Venezuela e no Brasil, a suspensão indefinidamente do primeiro país em 2017, bem como maior tensão entre os dois países.

Assim, a literatura analisada aqui parece concordar com o argumento avançado por Arana (2017), de que a política da UE em relação ao Mercosul é o resultado da reação à agenda de outros atores. Embora haja poucos trabalhos que abordam essa dimensão das negociações, parece que a arena doméstica ${ }^{88}$ da UE é relevante para explicar a mudança de ênfase da

\footnotetext{
${ }^{88}$ No caso do lançamento da Parceria Estratégica com o Brasil, a iniciativa atendia não apenas à estratégia da UE para países emergentes, mas também aos interesses da presidência da Comissão - no caso ocupada pelo português José Manoel Barroso. Nas entrevistas conduzidas por Hoffmann em 2008, ficou evidente que a decisão de lançar a P.E. atendeu a pressões "de cima para baixo" (HOFFMANN, 2009, p. 58)
} 
organização para a arena bilateral, conforme a contribuição recente de Van Loon (2018) enfatiza. 


\subsection{Estudos de caso V: CETA (Canadá), Coréia do Sul e Japão}

\subsubsection{Canadá}

Na Cúpula UE-Canadá de 2004, as autoridades canadenses e da UE decidiram lançar negociações para o Acordo de Promoção de Comércio e investimento. O objetivo do acordo era ir além de questões de acesso a mercado, para cobrir serviços, compras governamentais, investimento, propriedade intelectual, e qualificações profissionais (DUCHESNE \& MORIN, 2015, p. 6). Após interrupções e retomadas nas negociações, apenas em 2009 iniciou-se o processo que levou à assinatura de um acordo de livre comércio em outubro de 2013.

A UE representa o segundo mercado de exportações para o Canadá, atrás apenas dos EUA. As negociações começaram em 2009 no contexto de protecionismo crescente no momento imediato após a grande crise econômica. No entanto, o mercado canadense representa apenas $1.8 \%$ do total das exportações da UE, o que deu consideravelmente mais alavancagem para o bloco, e parcialmente explica porque as negociações não suscitaram muito debate público na Europa (D’ERMAN, 2016). Um dos principais aspectos controversos do acordo foi o IDSM (mecanismo de solução de controvérsias investidores-Estado)

Embora tivesse havido um alto grau de coesão da parte da UE durante as negociações, oposição ao acordo pelos Valões na Bélgica quase bloqueou o acordo nas semanas finais de tratativas. A principal questão de contestação estava em agricultura. No entanto, protestos contra o acordo também ocorreram no Canadá, onde os manifestantes denunciaram a ameaça à soberania nacional representada pelos investidores estrangeiros. Em adição, houve críticas domésticas a respeito da falta de transparência nas negociações. 
Tanto o APC concluído com o Canadá, como aquele concluído com a Coréia, foram baseados em mandatos endereçados à Comissão Europeia antes da entrada em vigor do Tratado de Lisboa, com muita confusão acerca do caráter normativo das mudanças trazidas pela introdução das novas regras de Lisboa na política comercial da UE. (DELIMATSIS, 2017, p. 588)

Trata-se de um dos maiores acordos de livre comércio em vigor, não apenas no que se refere ao tamanho dos mercados do Canadá e da Europa combinados, mas também em termos do escopo das áreas acordadas. O valor estimado de comércio internacional combinado é de 61,6 bilhões de dólares (COMISSÃO, 2013); em adição, o acordo visa a remoção de barreiras não-tarifárias (licenciamento especial; regimes regulatórios; e medidas anti-dumping) ao invés de barreiras comerciais tradicionais (tarifas aduaneiras; cotas), muitas das quais já são significativamente baixas entre o Canadá e a UE (D’ERMAN, 2016, p. 90).

Além disso, o acordo CETA é de valor estratégico para a UE, conforme Duchesne \& Morin (2013, p. 10)

"Sua [da UE] decisão de lançar o CETA foi parcialmente motivada pela aspiração de alguns atores políticos europeus de forjar relações comerciais com os EUA. Como uma expressão de seu interesse em cooperação econômica mais próxima com a América do Norte, às vésperas do lançamento do CETA, a UE assinou o Acordo Quadro para Avançar a Integração Econômica Transatlântica com os EUA. Como seu objetivo final, um acordo com o Canada poderia, portanto, servir como um laboratório institucional para harmonização regulatória transatlântica e como um precursor para um acordo maior"

Nesse sentido, também vale enfatizar os aspectos sublinhados por Hubner et al. (2017), no que se refere às motivações da UE para iniciar um acordo com o Canadá: 1) testar um dos elementos da estratégia Global Europe de 2006: incluir o setor de compras governamentais em futuros APCs ; 2) a competição geo-econômica e geopolítica crescente com a China; 3) o fracasso das negociações multilaterais de liberalização do comércio no âmbito da $\mathrm{OMC}$, bem como no que se refere ao acordo multilateral de investimento. Assim, a fim de colocar em 
prática os objetivos da estratégia Global Europe, a UE teria buscado cooperação econômica maior com parceiros novos.

Os atores-chave no lado europeu que pressionaram por um acordo com o Canadá foram a Comissão Europeia, uma maioria de Estados Membros liderados pela França, o Reino Unido, e a Alemanha, bem como grupos de lobby. No curso das negociações, organizações da sociedade civil emergiram como atores relevantes nos processos de elaboração de política comercial. A Comissão operou nas bases de suas recém atribuídas competências exclusivas em comércio de bens e serviços, aspectos comerciais da propriedade intelectual, e investimento estrangeiro direto. (FAFARD AND LEBLOND 2012, p. 14) (HUBNER ET AL., 2017, p. 848).

\subsubsection{Japão}

Em 2012, o Conselho deu um mandato à Comissão para iniciar negociações de comércio com o Japão. Na reunião de cúpula UE-Japão de 6 de julho de 2017, ambas as partes chegaram a um acordo em princípio sobre os principais elementos de um acordo de livre comércio, conhecido como acordo de parceria econômica (APE). (CONSELHO EUROPEU, 2017)

O caso do Japão é uma exceção em relação aos acordos almejados com os EUA e Canadá, pois não encontrou oposição de organizações da sociedade civil. No entanto, o acordo representa atualmente a terceira maior área econômica do mundo, tendo entrado em vigor em fevereiro de 2019 e é o maior já assinado pela Europa, com o valor de 600 bilhões de dólares. O acordo vai remover a maior parte do um bilhão de taxas pagas anualmente pelas companhias da UE que exportam para o Japão, e levou à remoção de um número de barreiras regulatórias de longa data, por exemplo em carros. Também vai abrir o mercado japonês de 127 milhões de consumidores para exportações agrícolas chave da UE e aumentará as oportunidades de exportação da UE em uma gama de outros setores. (SUZUKI, 2017) 
O Acordo de Parceria Econômica também vai fortalecer a cooperação entre a Europa e o Japão em um conjunto de áreas, reafirmar seu compromisso compartilhado com o desenvolvimento sustentável, e incluir pela primeira vez um comprometimento especifico com o acordo climático de Paris. (DG Comércio, 2018)

\section{Mandato de negociação}

As diretivas de negociação estabelecem que o acordo deverá conter exclusivamente provisões sobre comércio e áreas relacionadas ao comércio aplicáveis entre as partes. Ademais, o acordo deverá ser ambicioso, abrangente, equilibrado, e totalmente coerente com as regras e obrigações da OMC. Ademais, o acordo deveria garantir a liberalização progressiva e recíproca de comércio em bens e serviços, investimento, bem como no que se refere a questões relacionadas ao comércio.

O mandato estabelece que a eliminação abrangente e efetiva de barreiras não-tarifárias, como uma forma de melhorar o acesso a mercados e criar um campo de jogo nivelado para negócios europeus no Japão, é um dos objetivos mais importantes das negociações UE-Japão para um APC

As diretivas de negociação também estabelecem que o acordo deverá garantir a liberalização progressiva, abrangente, e recíproca de todos os setores econômicos e de comércio em serviços, com o objetivo de assegurar o mais alto nível de oportunidades de acesso a mercados, em consonância com as regras relevantes da $\mathrm{OMC}$, em particular o artigo V do GATS. Isso deveria ser sem prejuízo à possível exclusão de um número limitado de setores de serviços dos comprometimentos de liberalização. No entanto, também ficou estabelecido que os serviços audiovisuais não seriam cobertos por esse capítulo. 
No que se refere a direitos de propriedade intelectual, o mandato estabelece que o acordo deveria incluir regras para garantir a proteção efetiva e adequada desses direitos, e deveria complementar e basear-se nos TRIPs. Também deveria tratar de tópicos como direitos de propriedade e direitos relacionados, marcas registradas, indicações geográficas, designs, itens relacionados a patentes, responsabilidade de provedores de internet, bem como medidas de cumprimento de normas civis, administrativas e de fronteira.

O documento também estabelece que o acordo deverá estabelecer um comitê de comércio específico para monitorar a implementação do acordo. Comitês em áreas específicas poderão ser estabelecidos conforme apropriado e deverão operar sob o quadro do comitê comercial. O comitê comercial deverá reportar-se ao comitê conjunto estabelecido sob o Acordo Quadro. (CONSELHO DA UE, 2012)

\section{Política externa comercial e objetivos de segurança internacional}

A assinatura e entrada em vigor do APE entre a UE e o Japão pode marcar um divisor de águas nas relações do país asiático com os EUA. Conforme Suzuki (2017) enfatiza, isso significa um distanciamento da política japonesa de "América primeiro", no entanto também pode trazer consequências negativas para o Japão devido à incerteza sobre as relações com os EUA, bem como o posicionamento do país em relação ao TTP. Isso se deve essencialmente após o início da presidência de Donald Trump nos EUA e a postura anti-livre comércio por ele adotada.

No entanto, os rumos do TTP parecem ter sido mais clarificados recentemente, com a criação do CPTTP (parceria trans-pacífica abrangente e progressiva), que mantém boa parte do tratado original intacto, mas com mudanças importantes no que se refere a direitos de propriedade intelectual. Medidas que os EUA haviam pressionado para que fossem incluídas 
no acordo foram removidas, e a maior parte dos 11 países membros do CPTPP já ratificaram o acordo domesticamente (CFR, 2019).

Para a UE, o APE e a Parceria Estratégica, também assinada em 2018, deverão dar substância a uma política para a Ásia que se baseia em cinco pilares: promover mercados abertos; e regimes de livre-comércio; basear-se em relações bilaterais estratégicas para resolver desafios globais; contribuir para o desenvolvimento de ordens regionais baseadas em regras; forjar a conectividade; e garantir paz e estabilidade Assim, a UE espera elevar seu perfil como um parceiro de segurança relevante na Ásia (HELLENDORFF, 2018). Portanto, o APE também tem reflexos no domínio em que os EUA tradicionalmente eram o principal aliado do Japão.

A UE, em sua Estratégia Global, enfatiza a segurança e defesa como prioridades estratégicas chave. Embora mantendo uma parceria privilegiada com a OTAN, a UE tem expressado sua vontade de adquirir autonomia estratégica. Em maio de 2018 o Conselho adotou conclusões sobre "cooperação de segurança da UE na e com a Ásia", notando que há possibilidades importantes para aprofundar a cooperação de segurança com seus parceiros estratégicos asiáticos (Japão, mas também China, Índia e Coréia do Sul, em conjunto com os membros do ASEAN). (PARLAMENTO EUROPEU, 2019)

\subsubsection{Coréia do Sul}

O acordo de comércio UE-Coréia do Sul foi provisoriamente aplicado desde julho de 2011 e foi formalmente ratificado em dezembro de 2015. Ele vai além de qualquer acordo precedente no que se refere à suspensão de barreiras comerciais e foi também o primeiro acordo de comércio da UE com um país asiático. O tratado foi aditado em 2014 para permitir que a Croácia se beneficiasse das mesmas preferências que os outros 27 Estados Membros da UE, desde sua acessão ao bloco em $1^{\circ}$ de julho de 2013. (COMISSÃO EUROPÉIA, 2018) 
A partir do trabalho de (SAHAKYAN, 2015) e as entrevistas realizadas por esse autor, é possível afirmar que uma das principais forças que motivaram a UE a assinar um APC com a Coréia do Sul foi para nivelar o campo de jogo para exportadores europeus para a Coréia, antes dos efeitos discriminatórios do acordo EUA-Coreia se tornassem visíveis. Ademais, as companhias europeias estavam entre os maiores investidores na Coréia, e era importante para a UE garantir que suas multinacionais tivessem uma posição igual a de seus competidores dos EUA. A Coréia também seria um ponto ideal de entrada para as futuras relações de comércio da UE na Ásia Oriental (COMISSÃO EUROPÉIA, 2006; POLLET-FORT, 2011) (SAHAKYAN, 2015, p. 184)

As exportações da UE para a Coréia aumentaram em 77\% de 2010 a 2017. Isso mudou o comércio em bens da UE de um déficit de $€ 11,6$ bilhões em 2010 para um comércio amplamente equilibrado em 2017. As exportações de serviços da UE para a Coréia aumentaram em 70\%, comparado com 38\% para importações da UE da Coréia de 2010 a 2016. A UE teve um superávit de comercial de $€ 6$ bilhões em 2016 (COMISSÃO EUROPÉIA, 2018)

\section{Mandato de negociação}

No que se refere ao escopo da liberalização de tarifas, o mandato - à época representava o que havia de mais avançado, em comparação com acordos prévios. Igualmente, a cobertura de serviços era ambiciosa, e em uma gama de outras medidas, tais como o tratamento de barreiras técnicas ao comércio, proteção de direitos de propriedade intelectual incluindo indicadores geográficos - bem como em termos de provisões sobre solução de disputas e desenvolvimento sustentável, o mandato foi muito inovador. À época também representou um avanço no comércio, no contexto da estagnação da Rodada Doha (PARLAMENTO EUROPEU, 2010). 


\section{Relação com a estratégia mais ampla de comércio da $\mathbf{E U}$}

O acordo com a Coréia do Sul foi o primeiro concluído após a publicação da estratégia comercial "Global Europe" da Comissão, que conforme enfatizamos no segundo capítulo da tese, estabeleceu que "os principais interesses comerciais da EU, inclusive na Ásia, estariam menos bem servidos que aqueles referentes à vizinhança do bloco, ou objetivos de desenvolvimento" (COMISSÃO EUROPÉIA, 2006).

A estratégia do Global Europe, apontam Bossuyt et al. (2018, p.8), com seu foco em APCs comercialmente motivados, instigou uma discussão no Conselho sobre a inclusão de cláusulas políticas em acordos bilaterais, especialmente após a Índia ter se oposto repetidamente à inclusão da cláusula de elementos essenciais no APC proposto entre o país e a EU (Comissão Europeia, 2012, p. 3; Ahnlid, 2013, p. 204). O resultado foi que questões de política externa ficaram reservadas ao acordo-quadro de cooperação - que quase sempre é negociado em paralelo ao APC: isto é, questões relativas a direitos humanos e armas de destruição em massa ficaram restritas ao acordo-quadro. (BOSSUYT ET AL., 2018, p.8) 


\section{CONCLUSÃO}

\section{Introdução}

Este capítulo apresenta os resultados da análise empírica dos estudos de caso, de forma comparada, e sintetiza direções para pesquisa futura. A partir do quadro teórico delineado no capítulo 3, bem como das hipóteses ali apresentadas, é possível afirmar que fatores enraizados no sistema internacional são variáveis explicativas do desenho de política comercial europeia. Nesse quadro, a competição com atores rivais e a coesão da região homóloga são monitorados pela Comissão a fim de determinar a manutenção de um formato de negociação inter-regional, ou a mudança para a arena bilateral. Igualmente, complementando a tese do Realismo Comercial, este trabalho analisou o posicionamento da UE vis-à-vis potências emergentes (BRICS).

Reforça-se a percepção da tese de Meissner (2016), de que a UE é muito mais reativa ao sistema internacional do que a literatura de Relações Internacionais está disposta a assumir. E, mais problemático para o bloco é o fato de que não dispõe de uma estratégia para a mudança de equilíbrio de poder em curso no início do século XXI. Embora a UE tenha feito uso crescente de instrumentos bilaterais na arena do comércio internacional, a análise aqui desenvolvida não aponta para um distanciamento da política externa tradicional do bloco - baseada no interregionalismo e na promoção de valores caros ao projeto civilizacional europeu (respeito aos direitos humanos, desenvolvimento, proteção do meio ambiente). 
À medida que se intensificam os desafios externos - e internos - à UE torna-se premente a articulação de uma estratégia de ação na arena internacional, bem como uma coordenação mais efetiva do aparato institucional intra-europeu (DG Comércio, SEAE, Conselho). Nos estudos de caso primários (BRICS e GCC), a incoerência entre a política externa europeia e a política comercial do bloco ficou evidente. A análise empírica também reforçou a avaliação que os atores da UE não dispõem de uma preferência clara pelo inter-regionalismo ou pelo bilateralismo, em acordo com a proposição avançada pelo Realismo Comercial.

Esta tese também trouxe uma contribuição para os estudos sobre a coesão do GCC, por meio da aplicação do índice desenvolvido por Meissner (2016) para a coesão do bloco após a criação da União Aduaneira de 2003. Os resultados mostrados pelo indicador são congruentes com a análise da literatura secundária que apontam para uma redução expressiva da coesão dessa organização regional após a primavera árabe (2011). Nesse sentido, pesquisas adicionais sobre essa dimensão da política regional do Oriente Médio são bem-vindas, em também no que se refere a seus desdobramentos para a política externa da UE.

Finalmente, esta tese contribuiu para uma compreensão melhor da interação entre os níveis inter-regional e multilateral na política comercial europeia, especialmente levando em consideração o quadro presente de estagnação das negociações no âmbito da OMC. Assim, embora a UE não disponha de uma política específica para o grupo dos BRICS nesse domínio, o bloco europeu reagiu ao maior ativismo dos BRICS após a crise de 2008/09, porém buscando novos acordos com potências comerciais mais tradicionais. Esses dados empíricos reforçam o valor explicativo do desenho de política comercial da UE a partir de uma perspectiva realista e que é exposto em maior detalhe na seção seguinte. 


\section{Comparação dos estudos de caso}

A análise das negociações da UE com o GCC evidenciou a manutenção de um desenho de política inter-regional para essa organização, mesmo com a diminuição da coesão dos países do Golfo após a primavera árabe em 2011. Assim, esta tese propôs uma divisão das relações entre a UE e o GCC em dois períodos (2003-2011) e (2012-atual), conforme demonstrado na tabela abaixo (Tabela 16). O período posterior à primavera árabe também foi caracterizado por uma ação econômica menos intensa da China - o principal ator rival da UE - na região, e pela continuidade da incoerência da política comercial da UE para o GCC com o quadro mais amplo da política externa europeia para o Mediterrâneo e Oriente Médio (região MENA).

A ênfase da UE em relações mais próximas com o Brasil, a partir da parceria estratégica de 2007 - também parece ter sofrido mudança significativa a partir de 2016 com a intensificação da crise política no Brasil. Portanto, a análise deste estudo de caso adicionou um período novo na periodização desenvolvida por Meissner (2016), em que se manteve o formato abrangente nas negociações inter-regionais com o Mercosul, porém em um contexto de coesão regional menor que o período precedente.

O caso do TTIP também foi marcado pela abrangência de questões que integraram as negociações (questões regulatórias, serviços, propriedade intelectual, comércio em bens) e pelo caráter bilateral das negociações. Portanto, o resultado da variável dependente no que se refere à ação comercial externa da UE em relação aos EUA foi de bilateralismo abrangente. Diferentemente de tentativas anteriores de lançar negociações com o parceiro atlântico (no início dos anos 2000), o processo que levou ao mandato de negociação de 2013 não contou com oposição significativa de Estados Membros da UE. E, mais importante, a iniciativa serve a objetivos de política externa mais ampla do bloco, como consolidar o poder da UE como ator importante na arena de comércio internacional. 
A análise dos dados empíricos para o caso dos BRICS mostrou a produção de alguns documentos pelo aparato institucional europeu no momento de maior ascensão desses países como grupo (2009 - 2013). Conforme enfatizou-se no capítulo anterior - sem que esse movimento representasse a elaboração de uma política específica para essa coalizão no campo do comércio internacional. Os BRICS como grupo assim pertencem ao objetivo maior da UE de construir um multilateralismo efetivo (resultado da varável dependente). Ao longo do período mais recente de institucionalização do bloco (2014 - presente), a análise documental e literatura secundária não permitem afirmar que esteja em curso a elaboração de uma linha de ação específica para os BRICS. Permanece assim a tese da "disjunção estratégica" avançada por Freire (2017).

Tabela 16: Resultados para a variável dependente, complementando os casos analisados por Meissner (2016), McCrossan (2014) e Schade (2016).

\begin{tabular}{|c|c|c|}
\hline & Abrangente & Seletivo \\
\hline Interregionalismo & $\begin{array}{l}\text { UE - Mercosul I } \\
\text { UE - Mercosul II } \\
\text { UE - Mercosul III (2016-) } \\
\text { UE - SADC } \\
\text { UE - CAN } \\
\text { UE - ASEAN }\end{array}$ & $\begin{array}{c}\text { UE - GCC I (2003-2011) } \\
\text { UE - GCC II (2012-) }\end{array}$ \\
\hline Bilateralismo & $\begin{array}{l}\text { UE - Cingapura } \\
\text { UE - Equador, Peru, } \\
\text { Colômbia } \\
\text { UE - África do Sul } \\
\text { UE-EUA (TTIP) } \\
\text { UE - Japão } \\
\text { UE - Canadá (CETA) }\end{array}$ & UE - Brasil (2007-2015) \\
\hline
\end{tabular}

Fonte: Quadro adaptado a partir do original proposto por Meissner (2016). 
A análise dos estudos de caso primários, vide a tabela apresentada abaixo, permite afirmar que a Hipótese 1, de que o uso crescente de instrumentos bilaterais pela UE, reflete a ausência de uma estratégia europeia para a mudança de equilíbrio na arena internacional, tem suporte empírico. No caso dos BRICS, fica evidente a busca por acordos na arena bilateral com esses países - ou a mudança de ênfase de uma abordagem inter-regional para uma bilateral mas que só foi efetivada no caso da África do Sul. No caso das relações UE - GCC, há um monitoramento efetivo europeu das atividades de atores rivais não apenas a nível regional, mas também no nível bilateral - em que a Arábia Saudita tem tradicionalmente sido privilegiada pelos EUA.

Ambos os casos também demonstram o interesse da UE em manter o formato interregional de negociação, mesmo que isso represente obstáculo ao avanço do acordo de livrecomércio, no caso do GCC. No caso dos BRICS, efetivamente, o acordo com a África do Sul é na prática um acordo bi-regional, devido ao fato que esse país é membro da SADC - e no caso do Brasil, torna-se inviável um acordo bilateral em função do pertencimento ao Mercosul.

Prosseguindo a análise dos casos, verifica-se que em ambos a UE demonstra incapacidade de responder a desafios externos, explicitado de forma mais aguda no caso dos países BRICS, mas em menor medida também no do GCC. Conforme foi enfatizado no capítulo anterior, o grupo dos BRICS nem sequer aparece no documento mais importante da ação externa da UE, a Global Strategy de 2016. No caso dos países do Golfo, a UE também tem sido incapaz de atuar estrategicamente na região, conforme ficou demonstrado pela retirada unilateral do GCC da mesa de negociações em 2008 - e mesmo pela incapacidade de fazer frente a uma competição mais aguda com os BRICS após esse marco temporal (Hipótese 3).

Em ambos os casos (BRICS e GCC), a UE monitorou a atuação desses grupos de países, conforme ficou evidenciado pelos dados empíricos analisados nesta tese, e, portanto, a Hipótese 
4 passa um teste smoking-gun nesta etapa do mecanismo causal. Igualmente, o baixo grau de coesão entre os estados que compõem os BRICS e o GCC é um fator que parece ter sido determinante para o desenho de política comercial da UE em relação a esses atores. Desta forma, a hipótese 4 fica parcialmente confirmada, ressaltando os objetivos de ordem geopolítica da UE e sua relação com a escolha de arena para negociações na esfera comercial.

Passando à análise dos estudos de caso secundários, o caso do TTIP reúne evidências de que, em função do impasse na rodada Doha, e de forma mais acentuada após a crise de 2008/09, a UE passou a buscar a conclusão de novos acordos comerciais com grandes atores na arena internacional - assim dando suporte à Hipótese 3. O caso da parceria transatlântica, em que o parceiro negociador tem poder de barganha semelhante à UE, também reforçou a percepção de que o bloco europeu tem feito uso crescente de instrumentos comerciais para atingir objetivos geopolíticos, principalmente de manter a posição da UE como uma potência na arena do comércio internacional.

Conforme enfatizamos no capítulo precedente, a proposta inicial para um acordo com os EUA, na década de 1990, encontrou oposição de Estados Membros - ao passo que as negociações iniciadas em 2013 foram marcadas por resistência muito menor dos países europeus. Por outro lado, organizações da sociedade civil tiveram atuação mais forte a fim de evitar esse novo acordo megaregional. Nesse sentido, o caso do TTIP dá suporte à proposição do Realismo Comercial de que os grupos de interesse e Estados Membros tem influência na fase de rodadas de negociação. Em função da eleição de Donald Trump nos EUA e sua postura protecionista adotada desde então, torna-se pouco provável que o acordo seja concluído no curto prazo.

O estudo de caso do Mercosul forneceu evidências de que a baixa coesão do bloco especialmente no período pós-2016 - tem dificultado o progresso nas negociações que já se 
prolongam por mais de 20 anos. Da mesma forma, a ênfase da UE em buscar uma relação mais próxima com o Brasil - principalmente a partir da assinatura da parceria estratégica em 2007 mostra sinais de enfraquecimento devido à crise política em curso no país. E, da parte do Mercosul, o bloco parece já buscar alternativas - por exemplo um acordo com a UEE - à União Europeia. Embora o grau de coesão do Mercosul seja muito maior do que o do GCC, ele permanece baixo, e não levou a UE a considerar abandonar o formato inter-regional de negociações - o que dá suporte à Hipótese 4.

O objetivo da UE de buscar um acordo com o Mercosul também passou a ser entendido - a partir da Global Strategy de 2016 - como um meio de fortalecer o movimento em direção à conclusão do TTIP. Portanto o conjunto de evidências apresentado nesse estudo de caso reforça os dados de Meissner (2016), de que a UE não exibe uma preferência clara pela arena bilateral ou multilateral - e igualmente não permite afirmar que haja um distanciamento dos princípios tradicionais de política externa da UE - em síntese, são dados empíricos que dão suporte à Hipótese 2

Os estudos de caso secundários, referentes às negociações com Canadá, Japão e Coréia do Sul, ilustram o movimento da UE de buscar acordos com parceiros que tem maior peso na arena internacional de comércio, à semelhança do TTIP. Conforme explicado no capítulo anterior, o acordo com o Japão parece ser o que tem maiores ramificações em termos da estratégia da UE na respectiva região, principalmente em função do papel tradicional que os EUA tem desempenhado como aliado desse país. Dentre esses três casos, o Canadá (CETA) sobressai-se pelo grau de politização que as negociações alcançaram, à semelhança do que ocorreu no caso do TTIP. 


\begin{tabular}{|c|c|c|c|c|}
\hline & Hipótese 1 & Hipótese 2 & Hipótese 3 & Hipótese 4 \\
\hline $\begin{array}{l}\text { Estudo de caso I } \\
\text { (BRICS) }\end{array}$ & $\begin{array}{l}\text { Teste hoop (-) } \\
\text { Teste straw (-) } \\
\text { Teste hoop (+) }\end{array}$ & $\begin{array}{l}\text { Teste straw } \\
(+) \\
\text { Teste hoop } \\
(+) \\
\text { Teste hoop. } \\
(+)\end{array}$ & $\begin{array}{l}\text { Teste s-gun(-) } \\
\text { Teste hoop }(+) \\
\text { Teste s-gun(+) }\end{array}$ & $\begin{array}{l}\text { Teste s-gun (+) } \\
\text { Teste hoop (-) } \\
\text { Teste s-gun(-) }\end{array}$ \\
\hline $\begin{array}{l}\text { Estudo de caso } \\
\text { II (GCC) }\end{array}$ & $\begin{array}{l}\text { Teste hoop (-) } \\
\text { Teste straw (-) } \\
\text { Teste hoop (+) }\end{array}$ & $\begin{array}{l}\text { Teste straw } \\
(+) \\
\text { Teste hoop } \\
(+) \\
\text { Teste hoop. } \\
(-)\end{array}$ & $\begin{array}{l}\text { Teste s-gun }(+) \\
\text { Teste hoop }(+) \\
\text { Teste s-gun(-) }\end{array}$ & $\begin{array}{l}\text { Teste s-gun }(+) \\
\text { Teste hoop }(+) \\
\text { Teste s-gun }(+)\end{array}$ \\
\hline $\begin{array}{l}\text { Estudo de caso } \\
\text { III (Mercosul) }\end{array}$ & - & $\begin{array}{l}\text { Evidência } \\
\text { empírica }(+)\end{array}$ & - & $\begin{array}{l}\text { Evidência } \\
\text { empírica }(+)\end{array}$ \\
\hline $\begin{array}{l}\text { Estudo de caso } \\
\text { IV (TTIP) }\end{array}$ & $\begin{array}{l}\text { Evidência } \\
\text { empírica (-) }\end{array}$ & - & $\begin{array}{l}\text { Evidência } \\
\text { empírica }(+)\end{array}$ & - \\
\hline
\end{tabular}

No que se refere aos resultados da análise dos cabos diplomáticos (2003-2010), esses documentos reforçam os dados da literatura secundária, bem como das entrevistas realizadas pelos pesquisadores sobre a política externa comercial da UE. Atores-chave das instituições de comércio da UE manifestaram preocupação em concluir um acordo inter-regional com o GCC, ao mesmo tempo em que a atuação na arena de segurança regional (questão do Irã) ocupa lugar de destaque na agenda de política externa da UE. Os cabos diplomáticos também demonstram a proximidade e cooperação de Bruxelas com os EUA no período em consideração, bem como a participação dos Estados membros no processo de formulação de política externa da UE. Esses documentos também retrataram a ausência de uma política específica tanto dos EUA, como da UE, para os BRICS como grupo, que foi consolidado nos anos finais do período (20082009). 


\section{Em direção a uma diplomacia estratégica da UE?}

A partir da análise da atuação da UE nos estudos de caso abordados neste trabalho, esta seção traz uma reflexão sobre a atuação externa do bloco. O período em que os BRICS ainda estavam consolidando sua institucionalização (período embrionário), foi marcado por certa atenção à ascensão do bloco, no nível das instituições europeias. No entanto, essa tendência parece não ter se verificado no período posterior (a partir de 2014), quando são raros os documentos oficiais da UE que levam em consideração os BRICS. Esse período também coincide com a desaceleração econômica dos BRICS e o processo de crise política no Brasil (igualmente com a crise entre Ucrânia e Rússia).

Por outro lado, a percepção, nos países BRICS, de uma maior irrelevância da UE parece continuar a prevalecer, confirmando a avaliação de estudos que foram produzidos ao longo dos últimos anos. Com processos recentes que aumentaram a instabilidade na política mundial, como a eleição de Donald Trump nos EUA, o acirramento de tensões entre o país e a Rússia, bem como maior instabilidade no Oriente Médio - os desafios externos à UE parecem estar intensificando-se. Assim, o fato de que o bloco tenha buscado uma maior coerência entre as políticas externa e de outros domínios de ação externa - a partir de 2009 com o Tratado de Lisboa - são bem-vindas.

No entanto, os desafios internos à coesão da UE também se intensificaram muito com o processo do Brexit, a crise migratória, e endividamento de alguns Estados Membros. Portanto, é necessário avaliar com cautela o progresso obtido em termos de uma atuação diplomática européia mais coerente, e são necessários mais estudos a fim de avaliar os avanços trazidos pela nova configuração institucional da UE (especialmente em termos das agendas da Comissão, SEAE e Conselho). Conforme enfatizado na introdução do trabalho, as eleições de Maio de 2019 trarão um novo desafio para o futuro do bloco, em especial no que se refere a conter forças anti-democráticas de alguns estados membros e no Parlamento. 


\section{Agenda futura de pesquisa}

Tendo analisado os casos primários do GCC e dos BRICS, três principais eixos de investigação deveriam ser priorizados por trabalhos futuros sobre política comercial da UE. Primeiramente, são necessárias hipóteses adicionais no que diz respeito à articulação entre política comercial e política externa da UE, uma área de pesquisa ainda muito incipiente. Esta tese não adotou uma postura purista no que se refere à atuação comercial externa europeia, isto é, entende a política comercial como um instrumento adotado pela UE a fim de atingir objetivos econômicos externos. Nesse sentido, a abordagem realista para o estudo dessa dimensão da política externa da UE fornece alavancagem analítica para o pesquisador de relações internacionais - e assim novos estudos nessa linhagem seriam extremamente benéficas para a disciplina.

Em segundo lugar, trabalhos adicionais são necessários a respeito da ausência de uma estratégia coerente da UE para a ascensão de novas potências fora da Europa. A partir da tese do Realismo Comercial e do estudo de caso dos BRICS, reforça-se a percepção de que a UE é muito mais reativa aos desenvolvimentos na arena internacional do que o mainstream de ciência política e RI estão dispostos a admitir. Embora o grupo dos BRICS tenha perdido relevância em anos recentes, outras potências ${ }^{89}$ têm se articulado em coalizões, e deverão continuar a exercer pressão sobre a UE - em um contexto de instabilidade maior em função do impasse do Brexit e da crise migratória.

Da mesma forma, pesquisa adicional é necessária no que diz respeito à participação da UE em acordos megaregionais de comércio. Essa literatura ainda é muito incipiente, porém pode-se beneficiar de abordagens teóricas que enfatizam o aspecto geoeconômico e geopolítico

\footnotetext{
${ }^{89}$ Em 2011, O’Neill lançou o acrônimo MIKT, que engloba as potências emergentes México, Indonéia, Coréia do Sul e Turquia.
} 
da política comercial europeia - conforme ficou demonstrado pela análise dos casos do GCC e do TTIP. O movimento recente da UE em direção ao uso maior de instrumentos bilaterais na arena de comércio pode ser prejudicial ao sistema multilateral, e assim também avança a necessidade de mais trabalhos sobre o núcleo da política externa da UE. Os casos analisados nesta tese sugerem uma preponderância maior da dimensão de interesses (realista) sobre a agenda normativa do bloco. 


\section{BIBLIOGRAFIA}

ADRIAENSEN, J. Politics without Principals: National Trade Administrations and EU Trade Policy. 2014.

ADRIAENSEN, J.; GONZALEZ GARIBAY, M. From trading goods to trading punches: a study on the rise of regional trade agreements from a realist perspective. 2011.

AGGARWAL, V. K.; EVENETT, S. J. A Fragmenting Global Economy: A Weakened WTO, Mega FTA s, and Murky Protectionism. Swiss Political Science Review, v. 19, n. 4, p. 550557, 2013. ISSN 1424-7755.

AGGARWAL, V. K.; FOGARTY, E. A. EU trade strategies: between regionalism and globalism. Palgrave Macmillan, 2004. ISBN 1403932581.

AHNLID, A. The trade do-gooder? Linkages in EU free trade agreement negotiations. In: (Ed.). Linking trade and security: Springer, 2013. p.201-221.

AHNLID, A.; ELGSTRÖM, O. Challenging the European Union: the rising powers and the USA in the Doha Round. Contemporary politics, v. 20, n. 1, p. 77-89, 2014. ISSN 13569775 .

ALLEN, D.; SMITH, M. The EU, strategic diplomacy and the BRIC countries. The Diplomatic System of the European Union (DSEU), DSEU Policy Paper, n. 11, 2012.

ANTKIEWICZ, A.; MOMANI, B. Pursuing geopolitical stability through interregional trade: the EU's motives for negotiating with the gulf cooperation council. European Integration, v. 31, n. 2, p. 217-235, 2009. ISSN 0703-6337.

ARANA, A. G. Explaining the Renewed Push for an European Union Association Agreement with Mercosur. Revista Española de Relaciones Internacionales, n. 6, p. 136-158, 2014. ISSN 1989-6565. 
ARMIJO, L. E. The BRICs countries (Brazil, Russia, India, and China) as analytical category: mirage or insight? Asian perspective, p. 7-42, 2007. ISSN 0258-9184.

Financial Statecraft: No Longer Limited to the Incumbent Powers (SWP 62). 2018.

AYADI, R.; GADI, S. EU-GCC Trade and Investment Relations: What Prospect of an FTA between the Two Regions? Bridging the Gulf: EU-GCC Relations at a Crossroads, p. 47, 2013.

BACCINI, L. Explaining formation and design of EU trade agreements: The role of transparency and flexibility. European Union Politics, v. 11, n. 2, p. 195-217, Jun 2010. ISSN 1465-1165. Disponível em: <<Go to ISI >://WOS:000278435000002>.

BALDWIN 1, M. EU trade politics - heaven or hell? Journal of European Public Policy, v. 13, n. 6, p. 926-942, 2006. ISSN 1350-1763.

BARRINHA, A. Progressive realism and the EU's international actorness: towards a grand strategy? Journal of European Integration, v. 38, n. 4, p. 441-454, 2016. ISSN 0703-6337.

BAUMANN, R. O.; OLIVEIRA, I. T. M. O. Os BRICS e seus vizinhos: comércio e acordos regionais. 2014.

BIANCO, C.; STANSFIELD, G. The intra-GCC crises: mapping GCC fragmentation after 2011. International Affairs, v. 94, n. 3, p. 613-635, 2018. ISSN 0020-5850.

BICKERTON, C. J. Towards a social theory of EU foreign and security policy. JCMS: Journal of Common Market Studies, v. 49, n. 1, p. 171-190, 2011. ISSN 0021-9886.

BISCOP, S. Raiders of the lost art: strategy-making in Europe. Security Policy Brief, v. 40, p. $1-9,2012$.

The European Union and emerging powers in the 21st century: how Europe can shape a new global order. Routledge, 2016. ISBN 1317033108. 
BOENING, A.; KREMER, J.-F.; VAN LOON, A. Global Power Europe (Vol. 1 \& 2). Springer, 2013.

BOLLEN, Y.; DE VILLE, F.; ORBIE, J. EU trade policy: persistent liberalisation, contentious protectionism. Journal of European Integration, v. 38, n. 3, p. 279-294, Apr 2016. ISSN 0703-6337. Disponível em: <<Go to ISI>://WOS:000373112300005 >.

BÖRZEL, T. A.; RISSE, T. The transformative power of Europe: the European Union and the diffusion of ideas. 2009. ISSN 1868-7601.

BOSSUYT, F.; DRIEGHE, L.; ORBIE, J. Living apart together: EU comprehensive security from a trade perspective. European Foreign Affairs Review, v. 18, n. 4, p. 63-82, 2013. ISSN 1384-6299.

BOSSUYT, F.; ORBIE, J.; DRIEGHE, L. EU external policy coherence in the trade-foreign policy nexus: foreign policy through trade or strictly business? Journal of International Relations and Development, p. 1-22, 2018. ISSN 1408-6980.

BRETHERTON, C.; VOGLER, J. The European Union as a global actor. Routledge, 2005. ISBN 1134458827.

BREUSS, F. European Union in the Globalised World. In: (Ed.). The European Union in Crisis: Springer, 2015. p.219-257

BURCKHARDT, C. The European Union as an actor in international trade relations. In: (Ed.). Global Power Europe-Vol. 2: Springer, 2013. p.271-289.

BURKE, E.; ECHAGÜE, A.; YOUNGS, R. Why the European Union Needs a" broader Middle East" Policy. FRIDE Madrid, 2010.

CAPORASO, J. A. The European Union: Dilemmas of Regional Integration. Routledge, 2018. ISBN 0429965117. 
CARBONE, M.; ORBIE, J. Beyond Economic Partnership Agreements: the European Union and the trade-development nexus. Contemporary Politics, v. 20, n. 1, p. 1-9, 2014. ISSN 1356-9775.

CAREY, G.; MAHDI, W. GCC Members Suspend Free Trade Talks with Europe. Bloomberg, May, v. 26, 2010.

CARR, E. H. The twenty years crisis, 1919-39. An Introduction to the Study of, 1939.

CASLA, K. Realism: Human Rights Foe? Realism in Practice, p. 143, 2018.

COLOMBO, S. Bridging the Gulf: EU-GCC Relations at a Crossroads. Edizioni Nuova Cultura, 2014. ISBN 8868122847.

. EU-GCC RELATIONS AND THE RISK OF IRRELEVANCE. TURKISH POLICY QUARTERLY, v. 16, n. 3, p. 61-69, 2017. ISSN 1303-5754.

. EU-GCC RELATIONS AND THE RISK OF IRRELEVANCE. Turkish Policy Quarterly, v. 16, n. 3, p. 61-69, 2017. ISSN 1303-5754.

COMISSÃO EUROPÉIA. Trade for all - Towards a more responsible trade and investment policy. 2015

Report on the Implementation of the Trade Policy Strategy Trade for All Delivering a Progressive Trade Policy to Harness Globalisation., 2017.

COSTA, O. A União Europeia e sua política exterior (história, instituições e processo de tomada de decisão). Fundação Alexandre de Gusmão, 2016. ISBN 8576316676.

COX, M.; CARR, E. H. The twenty years' crisis, 1919-1939: an introduction to the study of international relations. Palgrave Macmillan, 2001. ISBN 0061311227. 
DA CONCEICAO-HELDT, E. Taming the Dragon: The EU and USA at the Negotiations for the Integration of China into Global Trade. Politische Vierteljahresschrift, v. 52, n. 1, p. 149151, 2011. ISSN 0032-3470. Disponível em: <<Go to ISI >://WOS:000309292900020>.

Do Agents "Run Amok"? A Comparison of Agency Slack in the EU and US Trade Policy in the Doha Round. Journal of Comparative Policy Analysis, v. 15, n. 1, p. 21-36, Feb 1 2013. ISSN 1387-6988. Disponível em: <<Go to ISI >://WOS:000327785800002 >.

DA CONCEIÇÃO-HELDT, E. When speaking with a single voice isn't enough: bargaining power (a) symmetry and EU external effectiveness in global trade governance. Journal of European Public Policy, v. 21, n. 7, p. 980-995, 2014. ISSN 1350-1763.

DAMRO, C. The new trade politics and EU competition policy: shopping for convergence and co-operation. Journal of European Public Policy, v. 13, n. 6, p. 867-886, Sep 2006. ISSN 1350-1763. Disponível em: $<<$ Go to ISI $>$ ://WOS:000240107000005 >.

. Market power Europe. Journal of European Public Policy, v. 19, n. 5, p. 682-699, 2012. ISSN 1350-1763. Disponível em: << Go to ISI >:/WOS:000304673600004 >.

Market power Europe: exploring a dynamic conceptual framework. Journal of European Public Policy, v. 22, n. 9, p. 1336-1354, Oct 21 2015. ISSN 1350-1763. Disponível em: $<<$ Go to ISI $>$ ://WOS:000357082600006 $>$.

DE BIÈVRE, D.; GSTÖHL, S.; VAN OMMEREN, E. Overcoming'Frankenfoods' and'secret courts': the resilience of EU trade policy. 2018.

DE BIEVRE, D. et al. International Institutions and Interest Mobilization: The WTO and Lobbying in EU and US Trade Policy. Journal of World Trade, v. 50, n. 2, p. 289-312, Apr 2016. ISSN 1011-6702. Disponível em: << Go to ISI >:/WOS:000374718300005 >.

DE OLIVEIRA, A. J.; ONUKI, J. Mercosul e BRICS: a convergência na Assembleia Geral das Nações Unidas. Geopolítica (s), v. 4, n. 1, p. 87-106, 2013. ISSN 2172-3958. 
DELIMATSIS, P. The Evolution of the EU External Trade Policy in Services-CETA, TTIP, and TiSA after Brexit. Journal of International Economic Law, v. 20, n. 3, p. 583-625, 2017. ISSN 1369-3034.

DEMMELHUBER, T.; KAUNERT, C. The EU and the Gulf monarchies: normative power Europe in search of a strategy for engagement. Cambridge Review of International Affairs, v. 27, n. 3, p. 574-592, 2014. ISSN 0955-7571.

D'ERMAN, V. J. Comparative intergovernmental politics: CETA negotiations between Canada and the EU. Politics and Governance, v. 4, n. 3, 2016. ISSN 2183-2463.

DESAI, R. Dreaming in technicolour? India as a BRIC economy. International Journal, v. 62, n. 4, p. 781-804, 2007. ISSN 0020-7020.

. Dreaming in technicolour? India as a BRIC economy. International Journal, v. 62, n. 4, p. 781-804, 2007. ISSN 0020-7020.

DO AMARAL JÚNIOR, A.; THORSTENSEN, V.; NOGUEIRA, T. R. BRICS in the World Trading System Emerging Economies in the WTO Dispute Settlement System. In: (Ed.). Settlements of Trade Disputes between China and Latin American Countries: Springer, 2015. p.147-180.

DOIDGE, M. Joined at the hip: Regionalism and interregionalism. European integration, v. 29, n. 2, p. 229-248, 2007. ISSN 0703-6337.

The European Union and interregionalism: Patterns of engagement. Routledge, 2016. ISBN 1317033043.

DRIESKENS, E.; VAN SCHAIK, L. G. The EU and effective multilateralism: Internal and external reform practices. Routledge, 2014. ISBN 1134715986.

DUCHÊNE, F. The European Community and the uncertainties of interdependence. In: (Ed.). A Nation Writ Large?: Springer, 1973. p.1-21. 
DUCHESNE, É.; MORIN, J.-F. Revisiting structural variables of trade negotiations: The case of the Canada-EU agreement. International negotiation, v. 18, n. 1, p. 5-24, 2013. ISSN 1571 8069.

DUGGAN, N. BRICS and the Evolution of a New Agenda within Global Governance. In: (Ed.). The European Union and the BRICS: Springer, 2015. p.11-25.

DUINA, F.; BUXBAUM, J. Regional trade agreements and the pursuit of state interests: institutional perspectives from NAFTA and Mercosur. Economy and Society, v. 37, n. 2, p. 193-223, 2008. ISSN 0308-5147.

DUR, A. EU trade policy as protection for exporters: The agreements with Mexico and Chile. Jcms-Journal of Common Market Studies, v. 45, n. 4, p. 833-855, Nov 2007. ISSN 00219886. Disponível em: $<<$ Go to ISI $>$ ://WOS:000250806400004 >.

Bringing economic interests back into the study of EU trade policy-making. British Journal of Politics \& International Relations, v. 10, n. 1, p. 27-45, Feb 2008. ISSN 13691481. Disponível em: $<<$ Go to ISI $>$ ://WOS:000254572200003 >.

DÜR, A.; BACCINI, L.; ELSIG, M. The design of international trade agreements: Introducing a new dataset. The Review of International Organizations, v. 9, n. 3, p. 353-375, 2014. ISSN 1559-7431.

DUR, A.; ELSIG, M. Principals, agents, and the European Union's foreign economic policies. Journal of European Public Policy, v. 18, n. 3, p. 323-338, 2011. ISSN 1350-1763. Disponível em: $<<$ Go to ISI $>$ :/WOS:000289504900001 $>$.

DUR, A.; ZIMMERMANN, H. Introduction: The EU in international trade negotiations. JcmsJournal of Common Market Studies, v. 45, n. 4, p. 771-787, Nov 2007. ISSN 0021-9886. Disponível em: $<<$ Go to ISI $>$ :/WOS:000250806400001 $>$.

ECHAGÜE, A. The European Union and the Gulf Cooperation Council. Fundación para 
las Relaciones Internacionales y el Diálogo Exterior, 2007.

EISSA, N. A. M. The Analysis Of Eu-Gcc Potential Free Trade Area Agreement Through EuGcc Actual Steps (1995-2012). World Review of Political Economy, v. 5, n. 3, p. 331-358, 2014. ISSN 2042-891X.

ELIASSON, L. J.; GARCÍA-DURAN, P. Why TTIP is an unprecedented geopolitical gamechanger, but not a Polanyian moment. Journal of European Public Policy, v. 24, n. 10, p. 1522-1533, 2017. ISSN 1350-1763.

ELSIG, M. The EU's choice of regulatory venues for trade negotiations: A tale of agency power? JCMS: Journal of Common Market Studies, v. 45, n. 4, p. 927-948, 2007. ISSN 0021-9886.

EMBAIXADA DOS EUA EM BRASILIA. BRAZIL: SCENESETTER - ECONOMIC PARTNERSHIP DIALOGUE

OCTOBER 30, 2008. 2008. Disponível em: < http://wikileaks.org/plusd/cables/08BRASILIA1418_a.html >.

BRAZIL'S LATIN AMERICA/CARIBBEAN SUMMIT: CONCENTRIC

CIRCLES OR CIRCLING THE WAGONS? , 2008. Disponível em: < http://wikileaks.org/plusd/cables/08BRASILIA1301_a.html >.

. S/P DIRECTOR GORDON HOLDS FIRST STRATEGIC TALKS WITH

BRAZIL. 2008. Disponível em: < http://wikileaks.org/plusd/cables/08BRASILIA756_a.html $>$.

BRAZIL: AMBASSADOR'S MEETINGS WITH MRE UNDER

SECRETARIES FOR POLITICAL AFFAIRS. 2010. Disponível em: < http://wikileaks.org/plusd/cables/10BRASILIA59_a.html >.

EMBAIXADA DOS EUA EM TOKYO. JAPAN NEGOTIATING FREE TRADE AGREEMENT WITH GULF COOPERATION COUNCIL MEMBERS 
2006. Disponível em: < http://wikileaks.org/plusd/cables/06TOKYO6298_a.html >.

EMBAIXADA DOS EUA NA ARÁBIA SAUDITA. GCC TRADE NEGOTIATIONS DOWN UNDER: STICKING POINTS AND

FRUSTRATION WITH THE GCC. 2009. Disponível em: < http://wikileaks.org/plusd/cables/09RIYADH935_a.html >.

. GULF COOPERATION COUNCIL LOOKING FOR GREATER TRADE AND

INVESTMENT WITH U.S., 2010. Disponível em: < http://wikileaks.org/plusd/cables/10RIYADH196_a.html >.

EMBAIXADA DOS EUA NA CIDADE DO KUWAIT. EU TRADE COMMISSIONER CRITICAL OF GCC STATE BILATERAL FTAS. 2005. Disponível em: < http://wikileaks.org/plusd/cables/05KUWAIT1465_a.html >.

EUROSTAT. International trade in goods - a statistical picture. 2018. ISSN 2443-8219.

FAFARD, P.; LEBLOND, P. Closing the deal: What role for the provinces in the final stages of the CETA negotiations? International Journal, v. 68, n. 4, p. 553-559, 2013. ISSN 00207020 .

FALKNER, G. The EU's current crisis and its policy effects: research design and comparative findings. Journal of European Integration, v. 38, n. 3, p. 219-235, Apr 2016. ISSN 07036337. Disponível em: $<<$ Go to ISI $>$ ://WOS:000373112300001 >.

FARRELL, M. A triumph of realism over idealism? Cooperation between the European Union and Africa. European Integration, v. 27, n. 3, p. 263-283, 2005. ISSN 0703-6337.

FEARON, J.; WENDT, A. Rationalism v. constructivism: a skeptical view. Handbook of international relations, p. 52-72, 2002.

FEDOSEEVA, S.; ZEIDAN, R. A dead-end tunnel or the light at the end of it: The role of BRICs in European exports. Economic Modelling, v. 59, p. 237-248, Dec 2016. ISSN 0264- 
9993. Disponível em: $<<$ Go to ISI $>$ :/WOS:000387191500020 $>$.

FIOTT, D. A revolution too far? Us defence innovation, Europe and NATO's militarytechnological gap. Journal of Strategic Studies, v. 40, n. 3, p. 417-437, 2017. ISSN 01402390.

FREIRE, M. R. EU Relations with the BRICS: Strategic Partnership or Structural Disjunction? International Organisations Research Journal, v. 12, n. 3, p. 182-200, 2017. ISSN 19967845 .

GALTUNG, J. The European Community: a superpower in the making. Universitetsforlaget Oslo, 1973. ISBN 8200093042.

GARCIA, M. From idealism to realism? EU preferential trade agreement policy. Journal of Contemporary European Research, v. 9, n. 4, 2013. ISSN 1815-347X.

GARCIA-DURAN, P.; MILLET, M. Reading EU trade policy from a multilateral perspective. Revista CIDOB d'Afers Internacionals, v. 119, n. 108, p. 119-140, 2014. ISSN 1133-6595.

GARCIA-DURAN, P.; MILLET, M.; ORBIE, J. EU Trade Policy Reaction to the BIC: From Accommodation to Entrenchment. In: BARBÉ, E.;COSTA, O., et al (Ed.). EU Policy Responses to a Shifting Multilateral System. London: Palgrave Macmillan UK, 2016. p.93114. ISBN 978-1-137-54758-3.

EU trade policy reaction to the BIC: from accommodation to entrenchment. In: (Ed.). EU Policy Responses to a Shifting Multilateral System: Springer, 2016. p.93-114.

GASTINGER, M. The tables have turned on the European Commission: the changing nature of the pre-negotiation phase in EU bilateral trade agreements. Journal of European Public Policy, v. 23, n. 9, p. 1367-1385, Oct 2016. ISSN 1350-1763. Disponível em: $<<$ Go to ISI $>$ ://WOS:000385514500010>.

GEGOUT, C. Europe has a strategy, but is the EU a strategic actor? , Fornet CFSP Forum, 
2005, FORNET. p.8-10.

GEHRING, T.; URBANSKI, K.; OBERTHÜR, S. The European Union as an inadvertent great power: EU actorness and the Ukraine crisis. JCMS: Journal of Common Market Studies, v. 55, n. 4, p. 727-743, 2017. ISSN 0021-9886.

. The European Union as an inadvertent great power: EU actorness and the Ukraine crisis. JCMS: Journal of Common Market Studies, v. 55, n. 4, p. 727-743, 2017. ISSN 00219886.

GEORGE, A. L.; BENNETT, A. Case studies and theory development in the social sciences. mit Press, 2005. ISBN 0262572222.

GEORGE, A. L.; MCKEOWN, T. J. Case studies and theories of organizational decision making. Advances in information processing in organizations, v. 2, n. 1, p. 21-58, 1985.

GILPIN, R. A realist perspective on international governance. Governing globalization: Power, authority and global governance, v. 3, p. 237, 2002. ISSN 074562734X.

GOLDSTEIN, J.; KEOHANE, R. O. Ideas and foreign policy: beliefs, institutions, and political change. Cornell University Press, 1993. ISBN 080148152X.

GOMES DA SILVA, R. R. G., E. R. BRICS como uma transnational advocacy coalition. 11o Encontro da ABCP. Curitiba 2018.

GRATIUS, S. The EU and its "Strategic Partnerships" with the BRICS. KonradAdenauer-Stiftung 2013.

GROSSE, T. G. Geoeconomic relations between the EU and China: the lessons from the EU weapon embargo and from Galileo. Geopolitics, v. 19, n. 1, p. 40-65, 2014. ISSN 1465-0045.

GRUMILLER, J. et al. Perspectives for export-oriented industrial policy strategies for selected African countries: case studies Côte d'Ivoire, Ghana and Tunisia. ÖFSE Research 
Report 10. Vienna. https://www. oefse. at/fileadmin/content .... 2018

GUZZINI, S. Realist theories and practice. 2017.

HÄNGGI, H. Interregionalism as a multifaceted phenomenon: In search of a typology. In: (Ed.). Interregionalism and international relations: Routledge, 2006. p.51-82.

HÄNGGI, H.; ROLOFF, R.; RÜLAND, J. Interregionalism and international relations. Psychology Press, 2006. ISBN 0415360579.

HAVLIK, P.; PINDYUK, O.; STOLLINGER, R. Trade in goods and services between the EU and the BRICs. Vienna: The Vienna Institute for International Economic Studies, 2009. ii, $43 \mathrm{p}$.

HAVLIK, P. et al. EU and BRICs: Challenges and opportunities for European competitiveness and cooperation. Industrial Policy and Economic Reform Papers, v. 13, 2009.

. EU and BRICs: Challenges and opportunities for European competitiveness and cooperation. Industrial Policy and Economic Reform Papers, v. 13, 2009.

HELLENDORF, B. Waiting for new deliverables: Can the EU-Japan strategic partnership measure up to global and regional challenges? EPC Policy Brief 10 April 2018. 2018.

HELWIG, N.; IVAN, P.; KOSTANYAN, H. The New EU Foreign Policy Architecture: Reviewing the first two years of the EEAS. 2013.

HÉRITIER, A.; PRAKASH, A. A Resource-based View of the EU's Regional and International Leadership. Global Policy, v. 6, n. 3, p. 247-255, 2015. ISSN 1758-5880.

HETTNE, B.; SODERBAUM, F. Civilian Power or Soft Imperialism-The EU as a Global Actor and the Role of Interregionalism. Eur. Foreign Aff. Rev., v. 10, p. 535, 2005.

HILL, C. What is to be done? Foreign policy as a site for political action. International Affairs, 
v. 79, n. 2, p. 233-255, 2003. ISSN 0020-5850.

HIRSCHMAN, A. O. National power and the structure of foreign trade. Univ of California Press, 1980. ISBN 0520040821.

HOANG, H. H.; SICURELLI, D. The EU's preferential trade agreements with Singapore and Vietnam. Market vs. normative imperatives. Contemporary Politics, p. 1-19, 2017. ISSN $1356-9775$.

HOANG, H. H.; SICURELLI, D. The EU's preferential trade agreements with Singapore and Vietnam. Market vs. normative imperatives. Contemporary Politics, v. 23, n. 4, p. 369-387, 2017. ISSN 1356-9775. Disponível em: << Go to ISI>:/WOS:000415691500002 >.

HOEKMAN, B. M.; MAVROIDIS, P. C. WTO 'à la carte'or 'menu du jour'? Assessing the Case for More Plurilateral Agreements. European Journal of International Law, v. 26, n. 2, p. 319-343, 2015. ISSN 1464-3596.

HOLDEN, P. Neo-liberalism by default? The European Union's trade and development policy in an era of crisis. Journal of International Relations and Development, v. 20, n. 2, p. 381407, 2017. ISSN 1408-6980.

HONGYU, L.; XING, L. G20 and C2: Sino-US Relations as an Institutional Cooperation Game? The BRICS and Beyond: The International Political Economy of the Emergence of a New World Order, p. 111, 2016. ISSN 1317040007.

HOWORTH, J. EU Global Strategy in a Changing World: Brussels' approach to the emerging powers. Contemporary Security Policy, v. 37, n. 3, p. 389-401, 2016. ISSN 1352-3260.

HUANYU, Z. Evolution of the BRICS institutionalization: challenges and opportunities for the EU Strategic Partnership with the BRICS. UACES Student Forum Conference 2016.

HUBNER, K.; DEMAN, A. S.; BALIK, T. EU and trade policy-making: the contentious case of CETA. Journal of European Integration, v. 39, n. 7, p. 843-857, 2017. ISSN 0703-6337. 
Disponível em: $<<$ Go to ISI $>$ :/WOS:000417636600006 $>$.

HULIARAS, A.; KALANTZAKOS, S. Looking for an Oasis of Support: Greece and the Gulf states. In: (Ed.). Foreign Policy Under Austerity: Springer, 2017. p.49-76.

HURT, S. R. Co-operation and coercion? The Cotonou Agreement between the European Union and ACP states and the end of the Lomé Convention. Third World Quarterly, v. 24, n. 1, p. 161-176, 2003. ISSN 0143-6597.

HYDE-PRICE, A. 'Normative'power Europe: a realist critique. Journal of European public policy, v. 13, n. 2, p. 217-234, 2006. ISSN 1350-1763.

JACOBS, L.; VAN ROSSEM, R. The rising powers and globalization: structural change to the global system between 1965 and 2005. Journal of World-Systems Research, v. 22, n. 2, p. 373-403, 2016. ISSN 1076-156X.

JACOBS, L. M.; VAN ROSSEM, R. The BRIC Phantom: A comparative analysis of the BRICs as a category of rising powers. Journal of Policy Modeling, v. 36, p. S47-S66, 2014. ISSN 0161-8938.

JØRGENSEN, K. E. Theorising the European Union's foreign policy. Rethinking European Union Foreign Policy, p. 10-25, 2004.

JORGENSEN, K. E. et al. The SAGE handbook of European foreign policy. Sage, 2015. ISBN 1473914434.

JUPILLE, J.; CAPORASO, J. A. States, agency, and rules: the European Union in global environmental politics. The European Union in the world community, v. 17, p. 157-182, 1998.

KAHLER, M. Rising powers and global governance: negotiating change in a resilient status quo. International Affairs, v. 89, n. 3, p. 711-729, 2013. ISSN 0020-5850. 
KALDOR, M.; MARTIN, M.; SELCHOW, S. Human security: a new strategic narrative for Europe. International affairs, v. 83, n. 2, p. 273-288, 2007. ISSN 0020-5850.

KERSSCHOT, M. Lost in aggregation: conclusions on domestic actor coordination in EU trade negotiations. 2016.

KETENCI, N. The bilateral trade flows of the EU in the presence of structural breaks. Empirical Economics, v. 51, n. 4, p. 1369-1398, Dec 2016. ISSN 0377-7332. Disponível em: $<<$ Go to ISI $>$ ://WOS:000387345900004 $>$.

KEUKELEIRE, S.; DE BRUYN, T. The European Union, the BRICS and Other Emerging Powers: A New World Order? International Relations and the European Union, p. 419-440, 2017.

KEUKELEIRE, S.; DELREUX, T. The foreign policy of the European Union: Palgrave Macmillan 2014.

KEUKELEIRE, S. et al. The EU foreign policy towards the BRICS and other emerging powers: Objectives and strategies. 2011.

KHANDEKAR, G. EU: India Strategic Partnership: From Blind Acknowledgement towards Recognition, The. Eur. Foreign Aff. Rev., v. 18, p. 487, 2013.

KIM, S. Y.; MANGER, M. S. Hubs of governance: Path dependence and higher-order effects of preferential trade agreement formation. Political Science Research and Methods, v. 5, n. 3, p. 467-488, 2017. ISSN 2049-8470.

KINGAH, S.; QUILICONI, C. Global and regional leadership of BRICS countries. Springer, 2016. ISBN 3319229710.

KIRSHNER, J. Realist political economy: traditional themes and contemporary challenges. In: (Ed.). Routledge Handbook of International Political Economy (IPE): Routledge, 2009. p.46-57. 
KIRTON, J. Explaining the BRICS summit solid, strengthening success. International Organisations Research Journal, v. 10, n. 2, p. 9-31, 2015.

KISSACK, R. Pursuing effective multilateralism: the European Union, international organisations and the politics of decision making. Springer, 2010. ISBN 0230281974.

KOCH, C. Constructing a viable EU-GCC partnership. 2014.

KOSTADINOVA, V. What is the Status of the EU-GCC Relationship. Gulf Research Center Gulf Papers, 2013.

KRAPOHL, S.; MEISSNER, K. L.; MUNTSCHICK, J. Regional Powers as Leaders or R ambos? The Ambivalent Behaviour of $\mathrm{B}$ razil and $\mathrm{S}$ outh $\mathrm{A}$ frica in Regional Economic Integration. JCMS: Journal of Common Market Studies, v. 52, n. 4, p. 879-895, 2014. ISSN 0021-9886.

LARSEN, M. F. Trade negotiations between the EU and South Africa: A three-level game. Jcms-Journal of Common Market Studies, v. 45, n. 4, p. 857-881, Nov 2007. ISSN 00219886. Disponível em: $<<$ Go to ISI $>$ ://WOS:000250806400005 >.

. The Increasing Power of the European Parliament: Negotiating the EU-India Free Trade Agreement. International Negotiation-a Journal of Theory and Practice, v. 22, n. 3, p. 473-498, 2017. ISSN 1382-340X. Disponível em: $<<$ Go to ISI $>$ ://WOS:000413029400006 $>$.

LAURSEN, F.; ROEDERER-RYNNING, C. Introduction: the new EU FTAs as contentious market regulation. Journal of European Integration, v. 39, n. 7, p. 763-779, 2017. ISSN 0703-6337.

LECHNER, L.; WÜTHRICH, S. Seal the Deal? Domestic Politics and Institutional Design in Preferential Trade Negotiations. 2016. 
LEE, M. C. The European Union-South Africa Free Trade Agreement: In Whose Interest? Journal of Contemporary African Studies, v. 20, n. 1, p. 81-106, 2002. ISSN 0258-9001.

LIJPHART, A. Comparative politics and the comparative method. American political science review, v. 65, n. 3, p. 682-693, 1971. ISSN 0003-0554.

LUTTWAK, E. N. From geopolitics to geo-economics: Logic of conflict, grammar of commerce. The National Interest, n. 20, p. 17-23, 1990. ISSN 0884-9382.

MACAJ, G.; NICOLAÏDIS, K. Beyond ‘one voice’? Global Europe's engagement with its own diversity. Journal of European Public Policy, v. 21, n. 7, p. 1067-1083, 2014. ISSN 13501763.

MACFARLANE, S. The 'R' in BRICs: is Russia an emerging power? International Affairs, v. 82 , n. 1, p. 41-57, 2006. ISSN 1468-2346.

MANNERS, I. Normative power Europe: a contradiction in terms? JCMS: Journal of common market studies, v. 40, n. 2, p. 235-258, 2002. ISSN 0021-9886.

MARTINI, J. et al. The Outlook for Arab Gulf Cooperation. Rand Corporation, 2016. ISBN 0833093088.

MASTANDUNO, M. Realism and Asia. The Oxford handbook of the international relations of Asia, p. 25, 2014. ISSN 019991625X.

MATTLIN, M.; WIGELL, M. Geoeconomics in the context of restive regional powers: Springer 2016.

MCKENZIE, L.; MEISSNER, K. L. Human Rights Conditionality in European Union Trade Negotiations: the Case of the EU-Singapore FTA. JCMS: Journal of Common Market Studies, 2016. ISSN 1468-5965.

MEENA, K. BRICS: an explanation in critical geography. Contexto Internacional, v. 35, n. 
2, p. 565-593, 2013. ISSN 0102-8529.

MEGIATO, E. I.; MASSUQUETTI, A.; DE AZEVEDO, A. F. Z. Impacts of integration of Brazil with the European Union through a general equilibrium model. EconomiA, v. 17, n. 1, p. 126-140, 2016. ISSN 1517-7580.

MEISSNER, K. L. A case of failed interregionalism? Analyzing the EU-ASEAN free trade agreement negotiations. Asia Europe Journal, v. 14, n. 3, p. 319-336, Sep 2016. ISSN 16102932. Disponível em: $<<$ Go to ISI $>$ ://WOS:000382144500005 >.

MEISSNER, K. L. Competing for economic power: South America, Southeast Asia, and commercial realism in European Union foreign policy. 2016.

MEISSNER, K. L. Leveraging interregionalism: EU strategic interests in Asia, Latin America and the Gulf region. International Politics, p. 1-16, 2017. ISSN 1384-5748.

MEUNIER, S. What single voice? European institutions and EU-US trade negotiations. International Organization, v. 54, n. 1, p. 103-+, Win 2000. ISSN 0020-8183. Disponível em: $<<$ Go to ISI $>$ ://WOS:000085466200004 $>$.

Managing globalization? The EU in international trade negotiations. Jcms-Journal of Common Market Studies, v. 45, n. 4, p. 905-926, Nov 2007. ISSN 0021-9886. Disponível em: $<<$ Go to ISI $>$ ://WOS:000250806400007 $>$.

MEUNIER, S.; NICOLAÏDIS, K. The European Union as a conflicted trade power. Journal of European Public Policy, v. 13, n. 6, p. 906-925, 2006. ISSN 1350-1763.

MIELNICZUK, F. BRICS in the Contemporary World: changing identities, converging interests. Third World Quarterly, v. 34, n. 6, p. 1075-1090, 2013. ISSN 0143-6597.

MILNER, H. Keynote address at IPE Seminar - USP. São Paulo. 2015.

MINGST, K. A.; ARREGUÍN-TOFT, I. M. Essentials of International Relations: Sixth 
International Student Edition. WW Norton \& Company, 2013. ISBN 0393937100.

MISSÃO DOS EUA NA EUROPA PARA A UNIÃO EUROPÉIA (BRUXELAS). IRAN SANCTIONS: U/S LEVEY MEETINGS WITH EU. 2008. Disponível em: < http://wikileaks.org/plusd/cables/08BRUSSELS1468_a.html >.

MISSIROLI, A.; O’SULLIVAN, D. BRICS-the Next Layer. Issue Altert, v. 38, 2013.

MORAVCSIK, A. The European constitutional settlement. World Economy, v. 31, n. 1, p. 158-183, Jan 2008. ISSN 0378-5920. Disponível em: $<<$ Go to ISI $>$ ://WOS:000252497300008 $>$.

MORI, A. EU and Latin America. A Stronger Partnership? , 2018. ISSN 8867059084.

MÜLLER, P. EU foreign policy: no major breakthrough despite multiple crises. Journal of European Integration, v. 38, n. 3, p. 359-374, 2016. ISSN 0703-6337.

MURAU, S.; SPANDLER, K. EU, US and ASEAN Actorness in G20 Financial PolicyMaking: Bridging the EU Studies-New Regionalism Divide. Jcms-Journal of Common Market Studies, v. 54, n. 4, p. 928-943, Jul 2016. ISSN 0021-9886. Disponível em: <<Go to ISI $>: / / W O S: 000384985800010>$.

MURRAY-EVANS, P. Regionalism and African agency: Negotiating an economic partnership agreement between the European Union and SADC-Minus. Third World Quarterly, v. 36, n. 10, p. 1845-1865, 2015. ISSN 0143-6597.

NARLIKAR, A. Negotiating the rise of new powers. International Affairs, v. 89, n. 3, p. 561$576,2013$.

NEUWIRTH, R. J.; SVETLICINII, A.; HALIS, D. D. C. (Ed.). The BRICS-Lawyers' Guide to Global Cooperation. Cambridge University Press, 2017.

NITOIU, C.; SUS, Monika. Introduction: strategy in EU foreign policy. 2017. 
O'NEILL, J. Building better global economic BRICs. 2001.

. The Growth Map: Economic opportunity in the BRICs and beyond. Penguin UK, 2011. ISBN 0241958067.

ORBIE, J. The European Union's role in world trade: harnessing globalisation? In: (Ed.). Europe's Global Role: Routledge, 2016. p.51-82.

ORSI, D.; AVGUSTIN, J.; NURNUS, M. The Practice of Realism in International Relations.

PARLAMENTO EUROPEU (DIRETORADO GERAL PARA POLÍTICAS EXTERIORES). Trade and economic relations between the EU and the GCC countries. 2017.

PETERSON, J. EU Trade Policy as Foreign Policy: Does Strategy plus Activity= Strategic Action?, 2007.

PHELAN, W. What is sui generis about the European Union? Costly international cooperation in a self-contained regime. International Studies Review, v. 14, n. 3, p. 367-385, 2012. ISSN $1468-2486$.

POLETTI, A.; DE BIEVRE, D. The political science of European trade policy: A literature review with a research outlook. Comparative European Politics, v. 12, n. 1, p. 101-119, 2014. ISSN 1472-4790.

POLETTI, A.; SICURELLI, D. The European Union, Preferential Trade Agreements, and the International Regulation of Sustainable Biofuels. Jcms-Journal of Common Market Studies, v. 54, n. 2, p. 249-266, Mar 2016. ISSN 0021-9886. Disponível em: $<<$ Go to ISI $>$ ://WOS:000369987400003 >.

POLLET-FORT, A. The EU-Korea FTA and its implications for the future EU-Singapore FTA. Background Brief No, v. 4, 2011. 
PRABHAKAR, A. C. et al. Foreign direct investment, trade and economic growth: A new paradigm of the BRICS. Modern Applied Science, v. 9, n. 12, p. 32, 2015. ISSN 1913-1844.

PUTNAM, R. D. Diplomacy and domestic politics: the logic of two-level games. International organization, v. 42, n. 3, p. 427-460, 1988. ISSN 1531-5088.

QUILICONI, C.; SAGUIER, M.; TUSSIE, D. BRICS: Leadership in the Making. In: (Ed.). Global and Regional Leadership of BRICS Countries: Springer, 2016. p.29-47.

RENARD, T. Partnerships for effective multilateralism? Assessing the compatibility between EU bilateralism, (inter-)regionalism and multilateralism. Cambridge Review of International Affairs, v. 29, n. 1, p. 18-35, Mar 2016. ISSN 0955-7571. Disponível em: $<<$ Go to ISI $>$ :/WOS:000377291000003 >.

REWIZORSKI, M. Another "Brick" in the Wall? Brazil's Quest for Relevance in Global Governance. Vestnik Mezhdunarodnykh Organizatsii-International Organisations Research Journal, v. 10, n. 2, p. 129-145, 2015. ISSN 1996-7845. Disponível em: $<<$ Go to ISI $>: / /$ WOS:000365693000011 >.

REWIZORSKI, M. The European Union and the BRICS. Springer, 2015. ISBN 3319190997.

RIBEIRO-HOFFMANN, A. EU-Mercosur relations after the EU-Brazilian strategic partnership. 2009. ISSN 857504138X.

ROBERT, G. War and Change in World Politics: Cambridge University Press, Cambridge 1981.

ROBLES JR, A. C. EU-ASEAN FTA: The EU's Failure as an International Actor, An. Eur. Foreign Aff. Rev., v. 13, p. 541, 2008.

ROSATO, S. Europe united: power politics and the making of the European Community. Cornell University Press, 2010. ISBN 0801461464. 
RÖSCH, F.; LEBOW, R. N. Realism: Tragedy, Power and the Refugee Crisis. Realism in Practice, p. 6, 2018.

ROTHKOPF, D. The BRICs and what the BRICs would be without China. Foreign Policy, v. $15,2009$.

RÜLAND, J. Balancers, multilateral utilities or regional identity builders? International relations and the study of interregionalism. Journal of European Public Policy, v. 17, n. 8, p. 1271-1283, 2010. ISSN 1350-1763.

Interregionalism and International Relations: Reanimating an Obsolescent Research Agenda? In: (Ed.). Intersecting interregionalism: Springer, 2014. p.15-35.

SAHAKYAN, D. EU Trade Policy Responses to the Proliferation of Preferential Trade Agreements in Latin America and East and Southeast Asia. Politics \& Policy, v. 44, n. 1, p. 74-96, Feb 2016. ISSN 1555-5623. Disponível em: $<<$ Go to ISI $>$ ://WOS:000374488700004 $>$.

SANTANDER, S. Vers un accord d'association de libre-échange interrégional UE/Mercosur: mirage ou réalité? Intervention économique, 2017.

SBRAGIA, A. The EU, the US, and trade policy: competitive interdependence in the management of globalization. Journal of European Public Policy, v. 17, n. 3, p. 368-382, 2010. ISSN 1350-1763. Disponível em: << Go to ISI $>$ :/WOS:000277589400005 >.

SCHADE, D. The European Union's Latin America policy: a study of foreign policy change and coordination. 2016. The London School of Economics and Political Science (LSE)

SCHARPF, F. W. Economic integration, democracy and the welfare state. Journal of European public policy, v. 4, n. 1, p. 18-36, 1997. ISSN 1350-1763. 
SCHIRM, S. A. Domestic ideas, institutions or interests? Explaining governmental preferences towards global economic governance. International Political Science Review, v. 37, n. 1, p. 66-80, Jan 2016. ISSN 0192-5121. Disponível em: $<<$ Go to ISI $>$ ://WOS:000367724700005 >.

SCHWELLER, R. L. Realism and the present great power system: Growth and positional conflict over scarce resources. Unipolar politics: realism and state strategies after the Cold War, p. 28-68, 1999.

SEZNEC, J.-F. The financial markets of the Arabian Gulf. Routledge, 2017. ISBN 1351333682.

SHKRELI, Y. The Role of European Union in Global Governance. World Academy of Science, Engineering and Technology, International Journal of Social, Behavioral, Educational, Economic, Business and Industrial Engineering, v. 9, n. 12, p. 4154-4159, 2015.

SICURELLI, D. The EU as a norm promoter through trade. The perceptions of Vietnamese elites. Asia Europe Journal, v. 13, n. 1, p. 23-39, Mar 2015. ISSN 1610-2932. Disponível em: $<<$ Go to ISI $>$ ://WOS:000349853000002 $>$.

SILES-BRUGGE, G. Resisting Protectionism after the Crisis: Strategic Economic Discourse and the EU-Korea Free Trade Agreement. New Political Economy, v. 16, n. 5, p. 627-653, 2011. ISSN 1356-3467. Disponível em: << Go to ISI>://WOS:000299433000005 >.

EU trade and development policy beyond the ACP: subordinating developmental to commercial imperatives in the reform of GSP. Contemporary Politics, v. 20, n. 1, p. 49-62, Jan 2 2014. ISSN 1356-9775. Disponível em: <<Go to ISI>://WOS:000331994000005 >.

. EU trade and development policy beyond the ACP: subordinating developmental to commercial imperatives in the reform of GSP. Contemporary Politics, v. 20, n. 1, p. 49-62, Jan 2 2014. ISSN 1356-9775. Disponível em: <<Go to ISI $>$ ://WOS:000331994000005 >.

SMITH, M. Foreign policy and development in the post-Lisbon European Union. Cambridge 
Review of International Affairs, v. 26, n. 3, p. 519-535, Sep 1 2013. ISSN 0955-7571. Disponível em: $<<$ Go to ISI $>$ :/WOS:000324978800003 $>$.

SMITH, M. The EU, Strategic Diplomacy and the BRIC Countries. The Diplomatic System of the European Union: Evolution, Change and Challenges, p. 115-128, 2016.

SMITH, N. R. The EU under a realist scope: Employing a neoclassical realist framework for the analysis of the EU's Deep and Comprehensive Free Trade Agreement offer to Ukraine. International Relations, v. 30, n. 1, p. 29-48, Mar 2016. ISSN 0047-1178. Disponível em: < $<$ Go to ISI $>$ ://WOS:000370429000002 >

SÖDERBAUM, F. Rethinking regionalism. Macmillan International Higher Education, 2015. ISBN 1137573031.

SODERBAUM, F.; STALGREN, P.; VAN LANGENHOVE, L. The EU as a global actor and the dynamics of interregionalism: a comparative analysis. Journal of European Integration, v. 27, n. 3 , p. 365 , 2005. ISSN 0703-6337.

SRINIVASAN, T. BRICS and the EU: An Oxymoron?(Panel 3). CESifo Forum, 2014. p.2014.

STRANGE, M. Power in global trade governance: is the EU a unitary actor, a tool for dominance, or a site of contestation? GATS and the TTIP negotiations. International Journal of Public Administration, v. 38, n. 12, p. 884-894, 2015. ISSN 0190-0692.

STUENKEL, O. BRICS e o futuro da ordem global. Editora Paz e Terra, 2017. ISBN 8577533735 .

SUS, M. Institutional innovation of EU's foreign and security policy: Big leap for EU's strategic actorness or much ADO about nothing? International Politics, p. 1-15, ISSN 13845748.

SUZUKI, H. The new politics of trade: EU-Japan. Journal of European Integration, v. 39, n. 7, p. 875-889, 2017. ISSN 0703-6337. 
TELÒ, M. European Union and new regionalism: regional actors and global governance in a post-hegemonic era. Ashgate Publishing, Ltd., 2013. ISBN 1409498212.

TOCCI, N. Framing the EU Global Strategy. Springer, 2017.

UJVARI, B. L'Union européenne face aux BRICS dans la gouvernance mondiale: Une réponse efficace?= The European Union facing the BRICS countries in world governance: an effective response? Bruges Regional Integration \& Global Governance Paper 2/2014. 2014.

VAILLANT, M. Mercosur: Southern integration under construction. 2005.

VAN DEN HOVEN, A. 11 European Union regulatory capitalism and multilateral trade negotiations. Values and principles in European Union foreign policy, v. 37, p. 185, 2006. ISSN 1134196113.

VAN EVERA, S. Guide to methods for students of political science. Cornell University Press, 1997. ISBN 080148457X.

VAN LOON, A. Globalization, Development and Integration: A European Perspective-Edited by P. Della Posta, M. Uvalic and A. Verdun. JCMS: Journal of Common Market Studies, v. 47, n. 5, p. 1137-1138, 2009. ISSN 0021-9886.

VAN LOON, A. Ideas, Institutions and Trade: The WTO and the Curious Role of EU Farm Policy in Trade Liberalization. Political Studies Review, v. 8, n. 3, p. 427-428, Sep 2010. ISSN 1478-9299. Disponível em: $<<$ Go to ISI $>$ ://WOS:000286395900092 >.

VAN LOON, A. Domestic politics in EU external economic relations: US-EU competition in trade. In: (Ed.). Global Power Europe-Vol. 1: Springer, 2013. p.219-234.

. From interregionalism to bilateralism: power and interests in EU-Brazil trade cooperation. In: (Ed.). The European Union and the BRICS: Springer, 2015. p.141-159. 
. The political economy of EU trade policy: what do we (not) know? Zeitschrift für Politikwissenschaft, v. 28, n. 1, p. 97-110, 2018. ISSN 1430-6387.

WEBBER, D. Declining Power Europe: The Evolution of the European Union's World Power in the Early 21st Century'. European Review of International Studies, v. 3, n. 1, p. 31-52, 2016.

WITMAN, R. G.; RODT, A. P. EU-Brazil relations: A strategic partnership. Eur. Foreign Aff. Rev., v. 17, p. 27, 2012.

WOOLCOCK, S. Trade policy. Policy-making in the European Union, p. 377-398, 2005.

WOOLCOCK, S. EU Policy on Preferential Trade Agreements in the 2000s: A Reorientation towards Commercial Aims. European Law Journal, v. 20, n. 6, p. 718-732, Nov 2014. ISSN 1351-5993. Disponível em: $<<$ Go to ISI $>$ ://WOS:000344331000002 >

WOUTERS, J. et al. Some Critical Issues in the EU-India Free Trade Agreement Negotiations. European Law Journal, v. 20, n. 6, p. 848-869, 2014. ISSN 1468-0386.

YOUNG, A. R. Trade politics ain't what it used to be: The European union in the Doha round. Jcms-Journal of Common Market Studies, v. 45, n. 4, p. 789-811, Nov 2007. ISSN 00219886. Disponível em: $<<$ Go to ISI $>$ ://WOS:000250806400002 $>$.

. The value of pointillism? Integrating trade and development and the European Union as a global actor. Contemporary Politics, v. 20, n. 1, p. 118-126, Jan 2 2014. ISSN 1356-9775. Disponível em: $<<$ Go to ISI $>$ :/WOS:000331994000010 $>$.

. European trade policy in interesting times. Journal of European Integration, v. 39, n. 7, p. 909-923, 2017. ISSN 0703-6337. Disponível em: $<<$ Go to ISI $>$ :/WOS:000417636600010>.

YOUNG, A. R. European trade policy in interesting times. Journal of European Integration, v. 39, n. 7, p. 909-923, 2017. ISSN 0703-6337. 
YOUNG, A. R.; PETERSON, J. The EU and the new trade politics. Journal of European Public Policy, v. 13, n. 6, p. 795-814, Sep 2006. ISSN 1350-1763. Disponível em: < < Go to ISI $>$ ://WOS:000240107000001 > .

. 'We care about you, but ... ': the politics of EU trade policy and development. Cambridge Review of International Affairs, v. 26, n. 3, p. 497-518, Sep 1 2013. ISSN 09557571. Disponível em: $<<$ Go to ISI $>$ ://WOS:000324978800002 >.

YOUNGS, R. Energy security: Europe's new foreign policy challenge. Routledge, 2009. ISBN 1134021186.

ZHAO, H. Evolution of the BRICS Institutionalization: Challenges and Opportunities for the EU Strategic Partnership with the BRICS. Trabalho apresentado na conferência da UACES Student Forum. 2016

ZIMMERMANN, H. Governance by Negotiation: The EU, the United States and China's Integration into the World Trade System. New Rules for Global Markets: Public and Private Governance in the World Economy, p. 67-+, 2004. Disponível em: $<<$ Go to ISI $>$ ://WOS:000282049500005 > .

ZIMMERMANN, H. Realist power Europe? The EU in the negotiations about China's and Russia's WTO accession. JCMS: Journal of Common Market Studies, v. 45, n. 4, p. 813832, 2007. ISSN 0021-9886.

Balancing sustainability and commerce in international negotiation: the EU and its fisheries partnership agreements. Journal of European Public Policy, v. 24, n. 1, p. 135-155, 2017. ISSN 1350-1763. 